\section{OAK RIDGE NATIONAL LABORATORY}

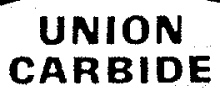

Fis

\section{Radioactive Solid Waste stordy and Disposal at Oak Ridge Wastos Laboratory}

Description and Salety havis

\section{OPERATED BY}

UUNON CARBDE CORPOBATION FOR THE UUITED STATES DEPARTMEIT OF ENEBGY
L. D. Bates

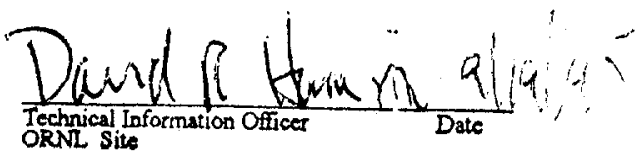


(2)

inc

Contract No. W-7405-eng-26

OPERATIONS DIVISION

RADIOACTIVE SOLID WASTE STORAGE AND DISPOSAL AT OAK RIDGE NATIONAL LABORATORY

DESCRIPTION AND SAFETY ANALYSIS

L. D. Bates

Date Published: October 1983

OAR RIDGE NATIONAL LABORATORY

Oak Ridge, Tennessee 37830 operated by UNION CARBIDE CORPORATION for the DEPARTMENT OF ENERGY 


\title{
RADIOACTIVE SOLID WASTE STORAGE AND DISPOSAL \\ AT OAK RIDGE NATIONAL LABORATORY \\ DESCRIPTION AND SAFETY ANALYSIS
}

Prepared by

ORNL OPERATIONS DIVISION

$\therefore$

$\because$
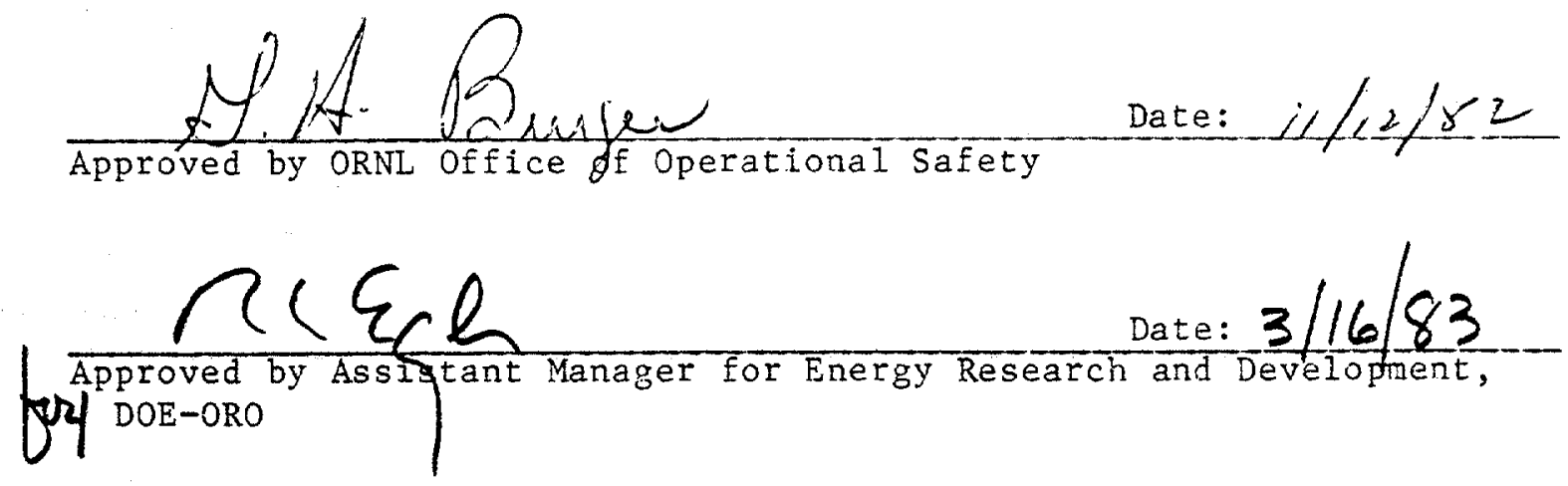

\author{
Prepared for the \\ DEPARTMENT OF ENERGY
}




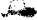

5

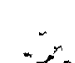

$=$

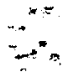


CONTENTS

\section{2}

$\therefore$

Page

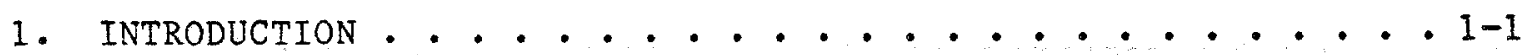

2. SUMMARY SAFETY ANALYSIS . . . . . . . . 2-1

2.1 Radiation SAFETY . . . . . . . . . 2-1

2.2 TOXIC MATERIAL SAFETY . . . . . . . . 2-3

2.3 CRITICALITY SAFETY ................ 2-3

2.4 FIRE SAFETY . . . . . . . . . . . 2-4

2.5 EXPLOSION AND HIGH PRESSURE SAFETY . . . . . . 2-5

2.6 NATURAL PHENOMENA CONSIDERATIONS . . . . . . 2-6

2.7 CONCLUSIONS . . . . . . . . . . . . . 2-6

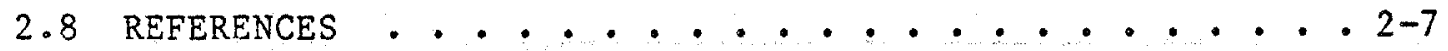

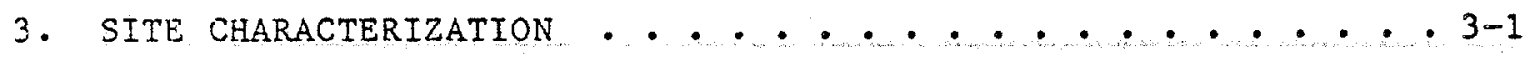

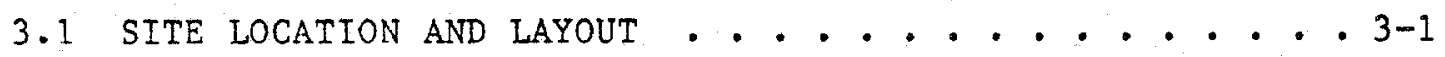

3.2 REFERENCES . . . . . . . . . . . . . . . . . .

4. FACILITY AND PROCESS DESCRIPTION ............. 4- . . .

4.1 CHARACTERIZATION OF THE WASTE $\cdots \cdot \cdot \cdot \cdot \cdot \cdot \cdot$

4.1.1 Waste Sources .............. 4-1

4.1 .2 Waste Types ............ 4-2

4.1.3 Waste Collection and Packaging........ 4-7

4.2 SOLID WASTE STORAGE AREAS ........... 4- . 4-27

4.2.1 Introduction .............. 4-27

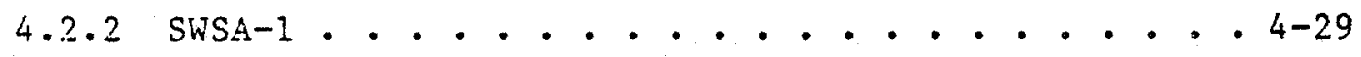

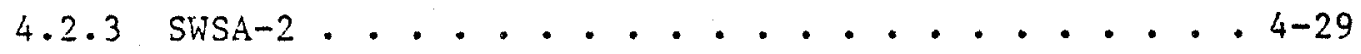

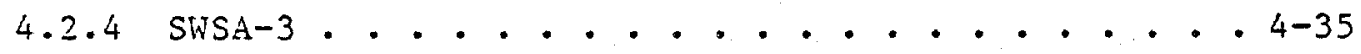

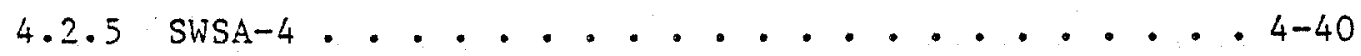

4.2 .6 SWSA $5 \ldots \ldots \ldots . \ldots . \ldots . \ldots 45$

4.2 .7 SWSA-6 ...................... 4- . . .

4.3 GENERAL SOLID WASTE DISPOSAI . . . . . . . 4-54

4.3 .1 Introduction ............. . . 4-54

4.3 .2 Trench Burial .............. 4-55

4.3 .3 Auger Holes ................ 4-62 
4.4 RETRIEVABLE SOLID WASTE STORAGE FACILITIES $\cdot \because \cdot \frac{\text { Page }}{4-63}$ 4.4.1 Introduction . . . . . . . . . . . 4-63

4.4.2 Staging Facility . . . . . . . . . . 4-63

4.4.3 Drum Storage Facility No. 1 . . . . . . . 4-64

4.4.4 Drum Storage Facility No. 2 . . . . . . . 4-69

4.4.5 Concrete Cask Storage Area . . . . . . . . 4-71

4.4.6 Concrete Cask Storage Building . . . . . . . 4-71

4.4.7 High Leve1 Wells . . . . . . . . . . . 4-75

4.5 SOLID WASTE COMPACTION . . . . . . . . . . 4-79

4.5.1 Introduction ............. . . 4-79

4.5.2 Solid Waste Compactor Facility . . . . . . . 4-80

4.5.3 Disposal of Compacted Waste . . . . . . . 4-82

4.6 SOLID WASTE STORAGE MONITORING AND SURVEILLANCE . . . . 4-88

4.6.1 Introduction . . . . . . . . . . . . 4-88

4.6.2 Monitoring Wells.............. 4-88

4.6.3 Streamflow Monitoring System . . . . . . . 4-89

4.7 SOLID WASTE STATISTICS . . . . . . . . . . 4-94

4.8 REFERENCES . . . . . . . . . . . . . . . 4-101

5. ACCIDENT ANALYSIS . . . . . . . . . . . . . . 5-1

5.1 RADIOLOGICAL IMPACT OF NORMAL OPERATIONS . . . . . . 5-1

5.2 BURIED WASTE ACCIDENTS . . . . . . . . . . . 5-6

5.2.1 Releases During Transport and Disposal . . . . 5-6

5.2.2 Natural Phenomena . . . . . . . . . 5-10

5.2 .3 Fire . . . . . . . . . . . . . 5-11

5.2.4 Trench Subsidence . . . . . . . . . . . 5-12

5.3 STORED WASTE ACCIDENTS . . . . . . . . . . . 5-12

5.3.1 Releases During Transport and Disposal . . . . 5-12

5.3 .2 Natural Phenomena ............. . 5-14

5.3 .3 Fire . . . . . . . . . . . . 5-16

5.3 .4 Loss of Container Integrity ......... . 5-16 
5.4 WASTE COMPACTOR FACILITY ACCIDENTS . . . . . . . 5-17

5.4.1 Releases During Transportation . . . . . . . 5-17

5.4.2 Process Incidents . . . . . . . . . 5-17

5.4.3 Natura1 Phenomena ........... . . . . 19

5.4 .4 Fire............... . . 5-19

5.4.5 Ventilation System Failure... . . . . . 5-20

5.4.6 Failure of Services . . . . . . . . 5-20

5.5 IMPACT ON ADJACENT OPERATIONS . . . . . . . . 5-21

5.6 HUMAN ERROR . . . . . . . . . . . . . . 5-21

5.7 RISK . . . . . . . ......... 5-22

5.8 REFERENCES . . . . . . . . . . . . . 5-25

6. QUALITY ASSURANCE . . . . . . . . . . . . . . . . . 5-1

6.1 QUALITY ASSURANCE PROGRAM DESCRIPTION . . . . . . . 6-1

6.2 ORNL QUALITY ASSURANCE ORGANIZATION . . . . . . . 6-1

6.3 OPERATIONS DIVISION QUALITY ASSURANCE PROGRAM . . . . 6-2

6.4 SWSA OPERATIONS QUALITY ASSURANCE . . . . . . . 6-2

6.5 REFERENCES ................... 6-3

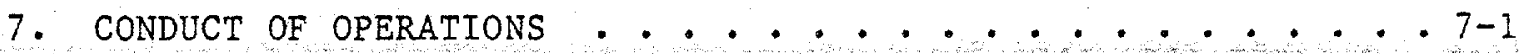

7.1 ORGANIZATIONAL STRUCTURE . . . . . . . . . . . 7-1

7.2 OPERATING PRACTICE AND PROCEDURE . . . . . . . . 7-6

7.2.1 Waste Handling Responsibility . . . . . . . 7-6

7.2.2 Disposal Practice and Limitations . . . . . . 7-9

7.2.3 Volume Reduction Program......... . . 7-15

7.3 SAFETY REVIEW SYSTEM . . . . . . . . . . . 7-18

7.4 PERSONNEL TRAINING ... . . . . . . . . . 7-20

7.5 CONFIGURATION CONTROL . . . . . . . . . . 7-21

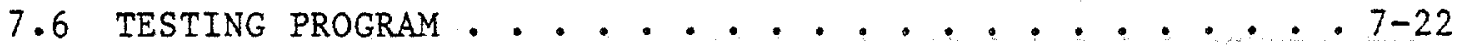

7.7 EMERGENCY PLANNING . . . . . . . . . . . . . 7-22

7.8 REFERENCES . . . . . . . . . . . . . . . . 25 APPENDIX A - ACCIDENT ANALYSIS CALCULATIONS . . . . . . . A-1 


\section{LIST OF FIGURES}

Figure

$\underline{\text { Page }}$

3.1 Topographical map of the ORNL site showing location of Solid Waste Storage Areas . . . . . . . . . . . 3-2

3.2 Aerial view of the Laboratory area . . . . . . . . . . 3-3

4.1 ORNL Solid Radioactive Waste Disposal Operations . . . . . 4-3

4.2 Low-level waste collection containers . . . . . . . . . . 4-11

4.3 Disposable low-level waste containers . . . . . . . . . 4-12

4.4 Dumpster for low-level waste collection . . . . . . . 4-15

4.5 Bottom discharge shielded carrier . . . . . . . . . 4-16

4.6 Lead shielded dumpster. . . . . . . . . . . . . 4-18

4.7 Shielded waste transport truck . . . . . . . . . . . 4-19

4.8 Stainless steel retrievable storage drum and closure hardware . . . . . . . . . . . . . . 4-20

4.9 Thin wall concrete cask . . . . . . . . . . . . 4-22

4.10 Intermediate wall concrete cask . . . . . . . . . 4-23

4.11 Thick wall concrete cask . . . . . . . . . . . . 4-24

4.12 Typical stainless steel high-level retrievable waste container . . . . . . . . . . . . . . . 4-25

4.13 Placement of high-level TRU waste in stainless steel lined well using shielded carrier . . . . . . . . . 4-26

4.14 Schematic diagram of SWSA-1 during operation . . . . . . 14-30

4.15 SWSA-1 site photograph . . . . . . . . . . . . 4-31

4.16 SWSA-2 site photograph . . . . . . . . . . . . . 4-32

4.17 Diagram of SWSA-2 site relative to present features . . . 4-33

4.18 Locations of core samples taken in area of proposed ESRL . . . . . . . . . . . . . . . . 4-36

4.19 SwSA-3 site photograph . . . . . . . . . . . . 4-37

4.20 Schematic diagram showing the orientation and general location of alpha and beta-gamna trenches in SWSA-3 . . . 4-38

4.21 SWSA-3 after cleanup . . . . . . . . . . . . . . 4-39

4.22 SWSA-4 site photograph . . . . . . . . . . . . . 4-41

4.23 Trench alignent and type cover at SWSA-4 . ...... 4-43 
4.24 SWSA-5 (south - nonretrievable) site photograph . . . . 4-46

4.25 Location and alignment of trenches and location of wells in SWSA-5 - south . . . . . . . . . . . 4-48

4.26 Retrievable waste facilities in SWSA-5 - north . . . . 4-49

4.27 Location and alignment of trenches in SWSA-5 - north . . . 4-50

4.28 SWSA-6 site photograph . . . . . . . . . . 4-52

4.29 Location and alignment of trenches and location of

wells in SWSA-6 as of June 1974 . . . . . . . . . 4-53

4.30 Typical disposal trench layout ............ 4-56

4.31 Properly excavated trench prior to placement of waste • • 4-57

4.32 Dumping of low-level waste dumpsters in disposal trench . 4-59

4.33 Typical waste in disposal trench before back filling . . . 4-60

4.34 Concrete collar surrounding trench monitoring well . . . 4 4-61

4.35 Interior of staging facility (7823) . . . . . . . 4-65

4.36 Drum storage buildings ( 7826 and 7834 ) and high-level storage wells (7827 and 7829) . . . . . . . . . 4-66

4.37 Retrievable drum storage facility (7826) - plan view . . 4 4-67

4.38 Retrievable drum storage facility (7826) - section view • 4-68

4.39 Retrievable drum storage facility (7834) - section view * 4-70

4.40 Retrievable burial of concrete casks . . . . . . . . 4-72

4.41 Concrete cask storage building (7855) - plan view . . . . 4-73

4.42 Concrete cask storage building (7855) - front elevation • 4-74

4.43 Concrete cask storage building (7855) - cross section . . 4-75

4.44 Concrete casks in place in Building 7855 . . . . . . . 4-77

4.45 High beta-gamma TRU storage facility (7827) . . . . . 4 4-78

4.46 Solid Waste Compactor Facility - Building 7831 - floor plan.................... . 4-81

4.47 Placement of box in waste compactor compression chamber . 4-83

4.48 Adding waste for compaction . . . . . . . . . . 4 4-84

4.49 Banded bale of compacted waste ready for removal . . . . 4-85

4.50 Covered trench for disposal of compacted waste . . . . . 4-86

4.51 Compacted waste bales inside disposal trench . . . . . 4-87 
4.52 Sketch of SWSA-3 showing groundwater contours and wel1 locations ................... 4-90

4.53 Location of groundwater monitoring wells for SWSA-4 . • . 4-91

4.54 Location plan for White Oak Creek sampling stations and radiation monitors . . . . . . . . . . . . 4-92

5.1 Near-surface sealing of trenches in SWSA-5 . . . . . . 5-7

5.2 Bentonite-shale surface seal in SWSA-5 . . . . . . . 5-8

7 . Laboratory organization . . . . . . . . . . . . 7-2

7.2 Nuclear fuel and waste programs organization . . . . . . 7-3

7.3 Operations Division organization . . . . . . . . . . 7-4

7.4 ORNL waste disposal responsibility . . . . . . . . . . 7-8

7.5 On-site waste disposal responsibility . . . . . . . . 7-10

7.6 Off-site waste disposal responsibility . . . . . . . . 7-11

7.7 Request for storage or disposal of radioactive solid waste or special materials . . . . . . . . . . 7-13

7.8 Typical volume-reduction publicity poster . . . . . . 7-16

7.9 Mechanical Design Change Memorandum . . . . . . . . 7-23

A.1 Downwind dose for a maximum plume height of 200- and 400-m stability condition D . . . . . . . . . . A-6

A.2 Downwind dose for a maximum plume height of 200 - and 400-m stability condition G . . . . . . . . . . . . A-7

A.3 Total dose for 200 - and 400-m plume rise for stability conditions D and $G$. . . . . . . . . . . . A-8

A.4 Downwind dose for an assumed plume rise of $25 \mathrm{~m}$ for stability conditions $D$ and $G$. . . . . . . . . . A-9 
$\frac{\text { Table }}{4.1}$ Radioactive solid waste disposal schedule . . . . . $\frac{\text { Page }}{4-9}$

4.2 Examples of compactible and noncompactible

contaminated wastes and acceptable containers. . . . . 4-14

4.3 ORNL solid waste storage areas . . . . . . . . 4-28

4.4 Solid-waste burials for 1957 and $1958 \ldots . . . . .444$

4.5 Land used for solid waste disposal . . . . . . . . 4-94

4.6 Total radioactive waste in SWSAs . . . . . . . . 4-95

4.7 Total annual activity, volume, and weight of solid waste buried or stored . . . . . . . . . . 4-96

4.8 High-radiation level alpha wastes in retrievable storage - below grade storage - Buildings 7827 , 7855 and trenches............... 4-98

4.9 Low-level alpha wastes in retrievable storage Buildings 7826 and 7834 . . . . . . . . . . 4-99

4.10 Fissile waste in SWSAs . . . . . . . . . . . 4-100

5.1 Discharge of ${ }^{90} \mathrm{Sr}$ from SWSA-4 and precipitation data for water - years 1963 through 1977 . . . . . 5-4

5.2 Discharge of ${ }^{90} \mathrm{Sr}$ from SWSA-5 and precipitation data for water - years 1967 through 1977 . . . . . 5-5

5.3 Risk of solid waste disposal operations . . . . . . . 5-23

7.1 Maximum operating limits for criticality control . • . . 7-14

7.2 Impact of Volume Reduction Program - waste buried in trenches and auger holes, FY-78 versus FY-79. . . . . 7-17

7.3 Impact of Volume Reduction Program - FY-79 reduction due to compactor and landfill operations . . . . . . 7-19 



\section{INTRODUCTION}

Oak Ridge National Laboratory (ORNL) is a principle Department of Energy (DOE) Research Institution operated by the Union Carbide Corporation - Nuclear Division (UCC-ND) under direction of the DOE Oak Ridge Operations Office (DOE-ORO). The Laboratory was established in east Tennessee, near what is now the city of Oak Ridge, in the mid 1940s as a part of the World War II effort to develop a nuclear weapon. Since its inception, disposal of radioactively contaminated materials, both solid and liquid, has been an integral part of Laboratory operations.

Through the years, a total of six geographical areas within the Laboratory have been used for the disposal or storage of radioactive solid waste. These designated areas, known as Solid Waste storage Areas (SWSA), and numbered sequentially one to six, contain a total of nearly $2 \times 10^{5} \mathrm{~m}^{3}$ of buried or stored solid waste (through FY-81). Most of the waste has been disposed of by a simple cut and fill trench burial technique. A small fraction of the wastes, primarily those contaminated with transuranic elements and/or those exhibiting a high beta-gamma radiation background, are buried either in auger holes and concrete casks, or are placed in stainless steel drums or wells in retrievable waste storage facilities.

Selection of early SWSA sites was initially based on convenience and security considerations with little regard for soil properties or potential for radionuclide migration within the storage area. Ease of excavation, proximity to the waste generation facilities, and other

operational factors were the initial determining considerations. Little or no data existed on which to evaluate the future performance of a potential site. However, around 1950, geologic and hydrologic studies were initiated which led to a more scientific method of site selection. It was realized, in particular, that areas underlain by conasauga shale formations make superior sites for shallow underground storage, not only because the shale is easily excavated, but because the ion exchange properties of the native material inhibit the migration of certain water 
soluble nuclides through the soil. The two most recent ORNL SWSAs have been sited in areas of abundant conasauga shale to take advantage of these properties.

Most of the waste contained in the ORNL SWSAs have been generated by ORNL or one of the other Union Carbide facilities ( $Y-12$ Plant and the Oak Ridge Gaseous Diffusion Plant) located in the Oak Ridge area. However, during the period from 1955 to 1963 the Laboratory's SwSAs were designated by the Atomic Energy Commission as the Southern Regional Burial Ground. During this period approximately $3 \times 10^{4} \mathrm{~m}^{3}$ of solid waste were disposed of from off-site sources. The ORNL SWSAs continue to be used on occasion, at the discretion of DOE, for disposal of off-site generated waste from other government agencies or government subcontractor sources, but this amounts to a very small fraction of current disposals.

The purpose of this document is to provide a detailed description of the ORNL Solid Waste Storage Areas, to describe the practice and procedure of their operation, and to address the health and safety inpacts and concerns of that operation. 


\section{SUMMARY SAFETY ANALYSIS}

This section provides a brief overview and summary of the major safety considerations of Solid Waste Storage Area management. Further details regarding the statements and conclusions in this summary may be found in the Accident Analysis, Section 5.

\subsection{RADIATION SAFETY}

Radiation exposures are minimized in solid waste operations primarily through control of the radiation level of the waste package. As a general guideline, solid waste packages are administratively limited to $200 \mathrm{mrem} / \mathrm{h}$ or less at the surface of the package. ORNL Health Physics Procedures require that, to the extent feasible, the generator provide adequate shielding of packages with radiation fields in excess of $200 \mathrm{mrem} / \mathrm{h}$ to reduce the radiation level. The major exceptions to this requirement are high radiation level waste in concrete casks or shielded carriers which, due to the configuration of the waste inside the container, may have isolated areas which exceed $200 \mathrm{mrem} / \mathrm{h}$ at the surface of the casic or carrier. These spots of high radiation field, historically up to $1 \mathrm{rem} / \mathrm{h}$, will be accepted if the majority of the cask or carrier meets the $200 \mathrm{mrem} / \mathrm{h}$ guidelines and all feasible measures have been taken to reduce the levels. Areas such as these are narked on the cask or carrier and all operations involving such disposals are monitored as necessary by Health Physics personnel. Disposals of this type are considered nonroutine and are handled as such. Special written procedures may be prepared if judged necessary for personnel protection.

General radwaste, which composes the bulk of the waste for disposal, is not handled directly by disposal personnel except in the case of compactible waste which is controlled to relatively low levels of activity. Noncompactible waste is picked up in the dumpster by a special truck, transported to the storage area in the dumpster, and then emptied directly from the dumpster into the disposal trench. This results in minimal radiation exposures to operations personnel. 
Compactible waste is contact handled in individual packages at the Waste Compactor Facility. This is necessary since individual bags of waste must be introduced manually to the compactor chamber. During the first year of compactor operation, personnel working in the facility were required to wear special dosimetry monitors while carrying out this operation. The results indicated, on the average, less than 3 mrem/operator/eight hour shift as a result of waste compactor operations.

SWSA operations personnel are routinely required to wear appropriate radiation detection devices in addition to regular dosineter (film-pack) badges. Pocket meters are read daily in accordance with ORNL Health Physics Procedures and any unusual exposures are reported to SWSA managenent. Any operations with potential exposures in excess of the limitations in the Health Physics Procedure Manual require a radiation work permit, Procedure 3.6 , in advance of initiation of the work. Any necessary monitoring or protection indicated on the work permit by the responsible Health Physics Surveyor will be followed. In addition to daily support by Industrial Safety and Applied Health Physics Personnel (ISAHP), all SWSA operations personnel have received training in radiation protection and monitoring which includes principles of radiation protection, use of radiation detection equipment, and familarity with the Health Physics Procedure Manual.

Open trenches, auger holes, etc. In the storage area are maintained to a radiation level of $200 \mathrm{mrem} / \mathrm{h}$ or less at grade level. Any trench or auger hole found to be in excess of this limit is backfilled until the radiation level is less than $200 \mathrm{mrem} / \mathrm{h}$. All completed and closed trenches are backfilled until the maximum radiation level at the surface is $2.5 \mathrm{mrem} / \mathrm{h}$. Most trenches are much less than this limit after backfilling to grade. Retrievable waste storage facilities have varying radiation fields due to the nature of the waste. Access to these facilities is restricted and all applicable procedures and precautions of the Health Physics Procedure Manual are followed when the facilities are opened and/or entered by SWSA personnel. The staging facility, Building 7823 , contains a minimum number of stainless steel drums which 
are generally less than $200 \mathrm{mrem} / \mathrm{h}$ and may be entered as necessary to place or remove drums. The general background level in the facility varies depending on the quantity of drums in the facility; however, operating experience has indicated that the levels are acceptable for the required work. Access to the facility is restricted and work time within the facility is minimized.

Numerous years of operating experience and monitoring have indicated that the above restraints are adequate to maintain personnel exposures as low as reasonably achievable.

\subsection{TOXIC MATERIAL SAFETY}

Toxic materials are not routinely disposed of in the ORNL SWSAs. Bulk compressed gases, liquids, or other such materials are not accepted for disposal except under special. conditions as described below. Only dry solids are routinely accepted for disposal in the SwSAs which limits the potential and hazards associated with toxic materials.

Pyrophorics and other such hazardous solid materials must be identified by the generator and, if accepted, are handled as a special disposal. All phases of the disposal are completed with due regard for the hazardous nature of the material. The ORNL Environmental Coordinator and/or the office of Operational Safety is notified of such intentions and is required to submit approval before such action will be permitted. If necessary, special procedures are prepared for the operations.

Historically, little or no toxic materials have been identified in ORNL solid radioactive waste and no changes are anticipated in the future. Special trenches in SWSA- 6 have been used for disposal of asbestos-containing materials but this is generally non-radioactive waste and is not a part of radioactive waste disposal operations.

\subsection{CRITICALITY SAFETY}

Criticality is prevented by limiting the quantity of fissionable material allowed in a given disposal container, trench, or facility depending on the nature of the disposal. These limits for various 
packages and containers are given in Table 7.1 of Section 7.2.2. Bulk material containing less than $1 \mathrm{gram} / \mathrm{ft}^{3}$ of fissible isotopes may be safely stored with no special consideration for criticality. Fissionable material in the above context is limited to the isotopes of $233_{\mathrm{U}}$, $235 \mathrm{U}$, and ${ }^{239} \mathrm{Pu}$ which comprise the majority of the fissionable material in the storage areas. Other isotopes which may have different critical masses are handled as unique cases.

The above limits were established by the ORNL Criticality Committee, and any deviations from these limits must be approved in advance by the Criticality Committee. It is the responsibility of the generator to ensure that any and all fissionable material is identified by isotope and quantity before a package will be accepted for disposal. Any future situation involving continued routine disposal of fissile quantities not covered by the above limits would be reviewed by the ORNL Criticality Comittee with subsequent revision of the ORNL Health Physics Procedure Manual and the SWSA Operating Procedure Manual to Include those recommendations.

\subsection{FIRE SAFETY}

The existence of a significant fire hazard is minimized through control of highly flammable materials in the solid waste and through fire resistant packaging of the more hazardous waste. Highly flamable materials such as certain organics or strong oxidizing agents are not routinely disposed of as solid waste. Flammable materials generally present in solid waste consists of contaminated paper, wood, and other items such as would be found in normal trash. Although combustible, this material presents small potential for initiation of a fire through explosion, chemical reaction, or spontaneous combustion. Any materials which present this potential are identified by the generator, and would be accepted only upon appropriate review and approval as described in Section 2.2 .

The greatest portion of the flammable material is contained in the low-level general radwaste. General radwaste is collected in standard dumpsters which contain a volume of either 108 or $260 \mathrm{ft}^{3}$. The material 
is then transported to the storage area and placed in a trench which is backfilled with soil when full. Any fire involving general radwaste would involve only the amount of waste in a dumpster or the amount of waste accumulated in a given trench. The relatively low specific activity of this waste ensures that only a small quantity of radionuclides would be involved in any fire of this type (see Appendix A).

Higher activity waste or transuranic waste is packaged in stainless steel drums or canisters, concrete casks, or other types of shielded containers which although designed primarily for containment and radiation shielding are also relatively fire resistant. The steel drums and concrete casks are currently placed in cellular storage buildings. The packaging of the waste practically eliminates all conceivable sources for a fire plus the unavailability of oxygen inside the container would extinguish any fire which could be ignited. In the unlikely event a fire did occur in the waste, it would be limited to the amount of waste within a given cell of a storage facility. Additionally, most higher level waste consists of contaminated equipment or other similar waste which has little or no combustibility.

In the event a fire does occur, the ORNL Fire Department would be notified immediately. ORNL Fire Department personnel are trained in the proper methods of handling fires involving radioactive material. A Health Physics Surveyor would also respond to the fire along with other members of the Emergency Crew to assist in any radiation or contamination problems. When the fire is extinguished, the area near the fire would be surveyed for contamination and clean-up procedures or decontamination measures would be initiated, as necessary.

\subsection{EXPLOSION AND HIGH PRESSURE SAFETY}

Explosion and high pressure safety is not a significant consideration in SWSA operations. As outlined in the section above, no material capable of chemical or flammable explosions is routinely accepted for disposa1. No compressed gases or other high pressure sources are routinely accepted for disposal, and no high pressure equipment outside the realm of ordinary industrial safety is utilized in SWSA operations. 


\subsection{NATURAL PHENOMENA CONSIDERATIONS}

Natural phenomena do not present a significant potential for release of radionuclides from the storage areas. All the storage areas except a small peripheral area of SWSA-6 and SWSA-1 are above the elevation of the maximum probable flood plane and thus would not be subject to flood damage. Buried waste is relatively immune to all types of natural phenomena with two minor exceptions. An earthquake could open a fissure across a waste trench and expose the waste therein. Some of this waste could be scattered around the immediate area and would require radiation survey and cleanup. A tornado passing over a partially filled trench could remove waste from the trench and redeposit it some distance away from the trench. In both these cases, the environmental impact would be minimal due to the low specific activity of the waste. In the case of the earthquake, the contamination would most likely be local and could be cleaned up. The tornado scenario is not a major consideration due to the extremely low potential for a tornado in the vicinity of ORNL.

The retrievable storage facilities containing the transuranic waste are designed and built for local earthquake and tornado resistance. The buried concrete casks would not be susceptible to tornado damage since they are below grade and would not likely be danaged by an earthquake due to their construction of reinforced concrete.

\subsection{CONCLUSIONS}

This report illustrates that the operation of the Solid Waste Storage Areas at the Oak Ridge National Laboratory presents no siznificant hazard to the public, the environment, nor, as the record shows, has it resulted in any significant safety hazard to the personnel involved in SWSA operations.

Numerous programs are in process at the Laboratory to ensure that Solid Waste Storage Areas will continue to operate in a safe and acceptable manner. Seepage from the storage areas is monitored and researched by the ORNL Environmental Sciences Division using the Streamflow Monitoring System and the SWSA groundwater monitoring system. 
This data is reported to the ORNL Environmental Coordinator's office, which in turn, summarizes the information for review by the Department of Energy, Environmental Protection Agency, and other interested groups.

The volume reduction program is being vigorously pursued to reduce the land usuage for solid waste operations and extend the life of the current ORNL SWSAs. Research and development is being carried out in the area of transuranic waste assay to quantify the isotopic content of individual waste packages independent of the generator.

Many long range study programs are currently in process such as studies on the alternatives to shallow land burial and studies on the alternatives for future disposal of the current transuranic waste inventory. It is assured that these studies and programs will not only improve the safety of ORNL Solid waste operations as they currently exist but will likely provide new methods and techniques for even greater safety and long range containment of radioactive solid waste.

One recent study by Gilbert Associates, Inc. ${ }^{1}$ on the alternatives for the future disposition of stored transuranic waste at ORNL concluded that within a projected 100-year period of continued institutional control of the ORNL stored transuranic waste, dose commitments to either personnel or the general public, could be expected to be negligible.

\subsection{REFERENCES}

1. Gilbert/Commonwealth, Assessment of Alternatives for Management of ORNL Retrievable Transuranic Waste, ORNL/Sub-79/13837/5, February 1981 . 


\section{SITE CHARACTERIZATION}

\subsection{SITE LOCATION AND LAYOUT}

The ORNL Solid Waste Storage Areas and associated facilities are located within the confines of the Oak Ridge National Laboratory.

The Laboratory consists of a central administrative and research complex comprising many of the ORNL's primary facilities. Several outlying areas contain special facilities such as the High Flux Isotope Reactor and the Tower Shielding Facility in addition to the Solid Waste Storage Areas and other waste disposal facilities. Figure 3.1 is a topographical map showing the central Laboratory and each of the Solid Waste Storage Areas and burial grounds. 1

The central Laboratory area is located in Bethel Valley between Chestnut Ridge and Haw Ridge at an elevation of approximately $244 \mathrm{~m}$ $(800 \mathrm{ft})$. Bethel Valley Road passes around the perimeter of the central Laboratory and provides the primary route in and out of the Laboratory complex. The central Laboratory is divided into geographical sections numbered sequentially from 1,000 to 7,000 . The 1,000 area is located at the west end of the complex with the eastern portion being the 7,000 area. Building numbers are assigned in accordance with this system.

Three of the Solid Waste Storage Areas, SWSA-1, -2 , and -3 , are located in Bethel Valley adjacent to the Laboratory complex. The remaining three storage areas, SWSA-4, -5 , and -6 are located in Melton Valley on the opposite (south) side of Haw Ridge. Primary access to these latter areas is Lagoon Road and Melton Valley Drive, which passes through a gap in Haw Ridge at the west end of the central Laboratory (Fig. 3.2).

Additional information on the site description may be found in the ORNL site generic document. ${ }^{2}$ 


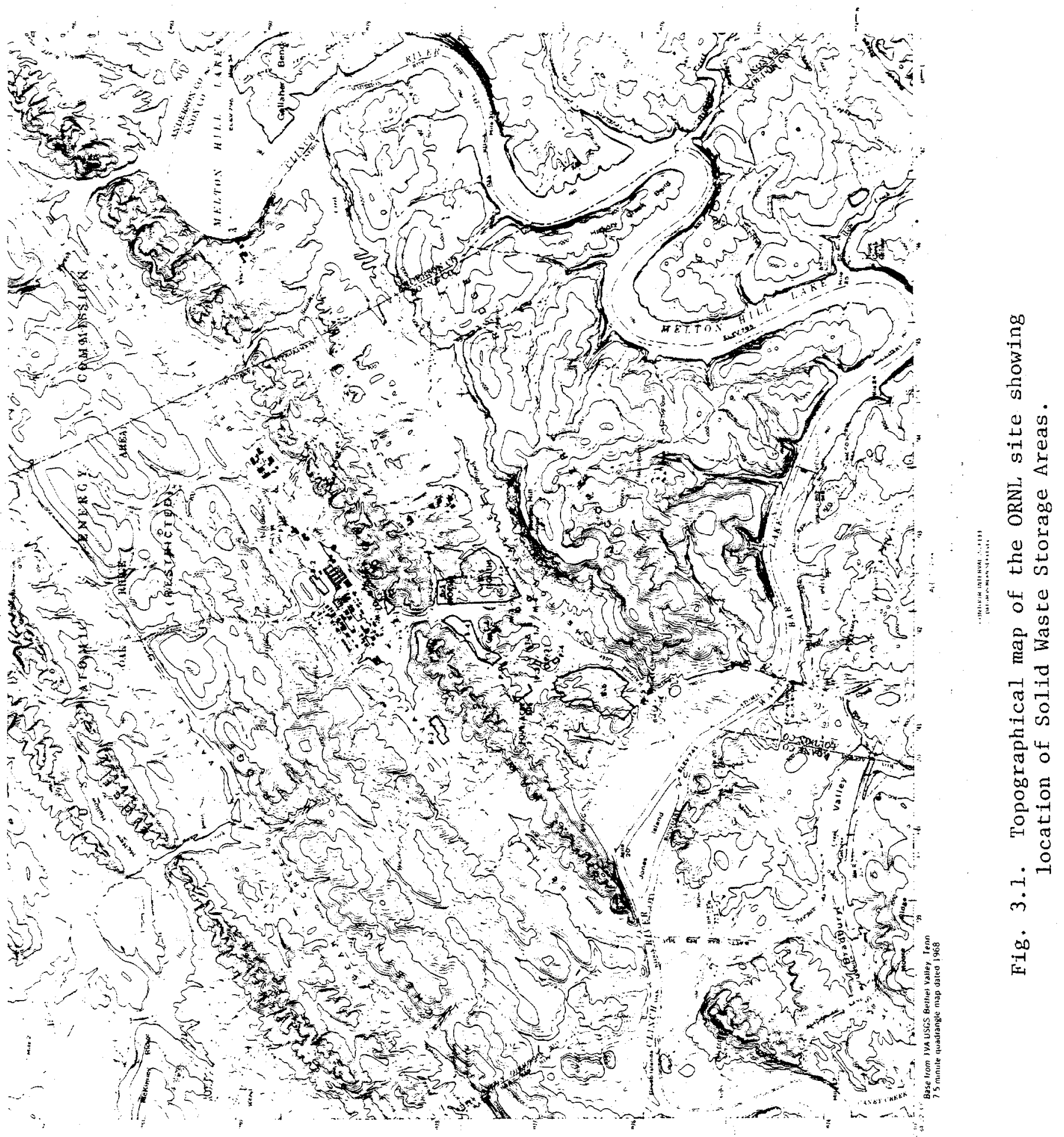

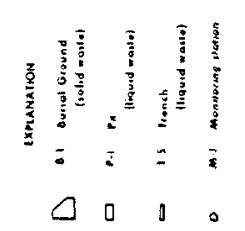




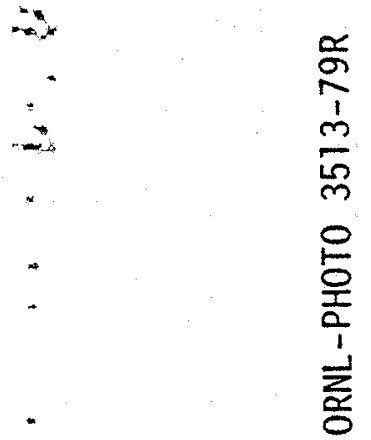
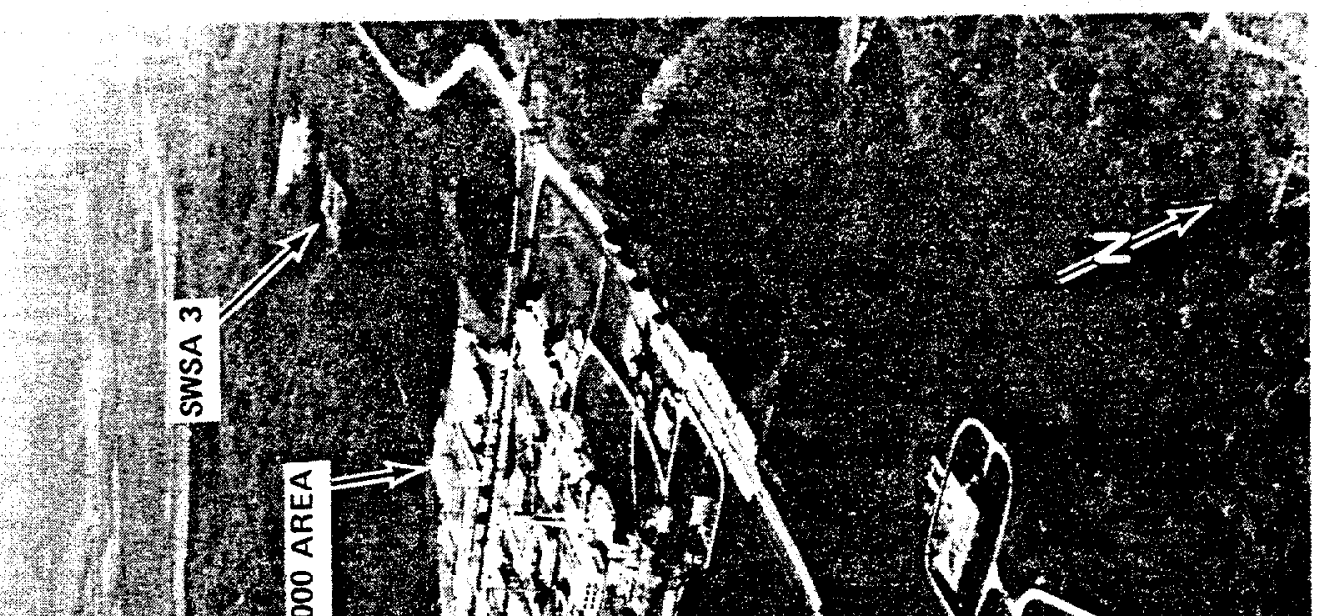

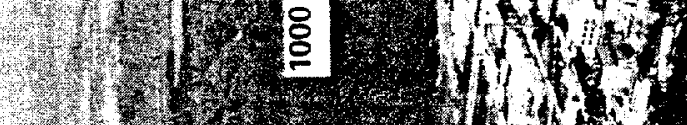

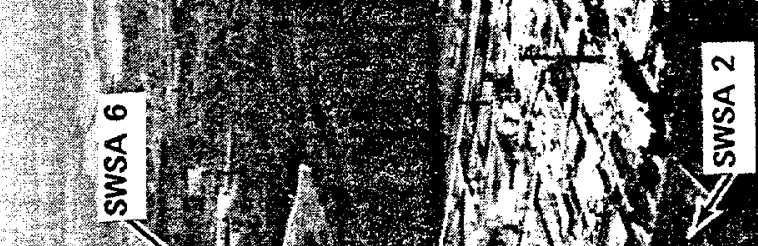

and

$\therefore$

1.25 25
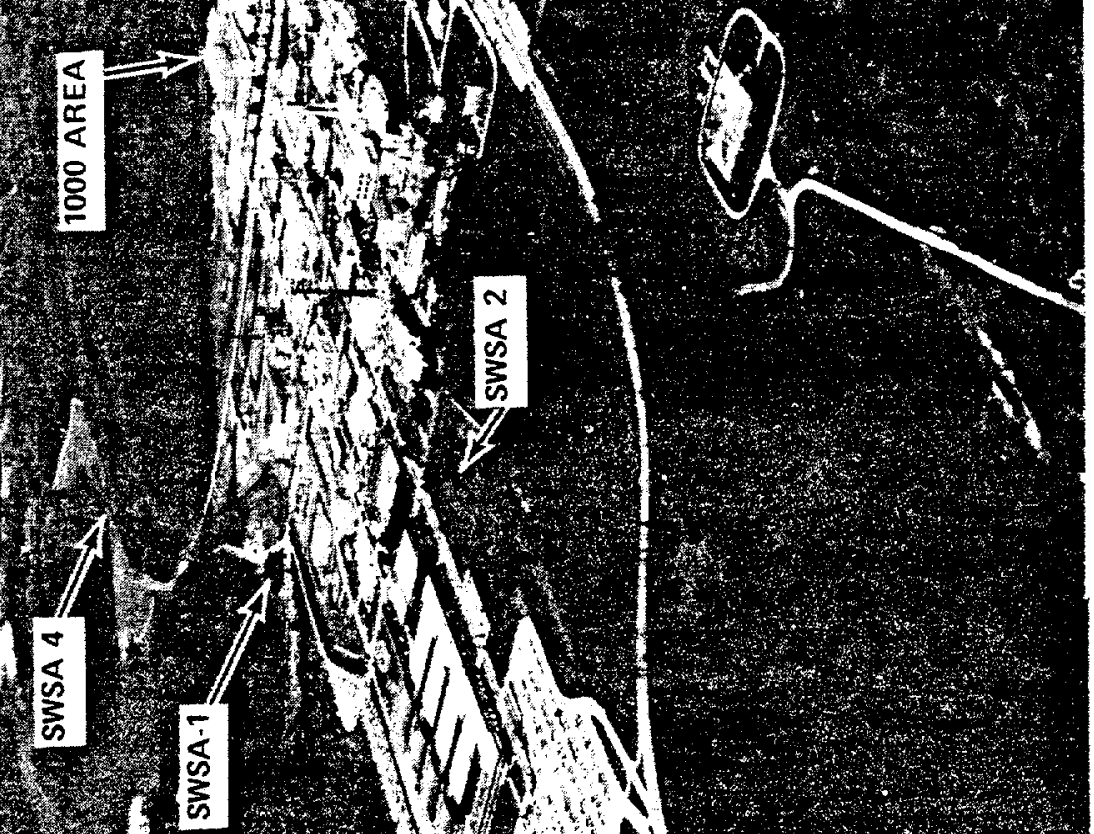

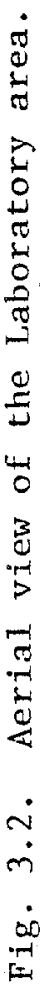

3.t.
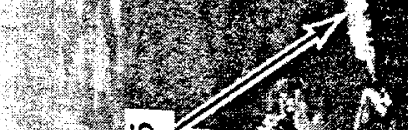

is

(1)

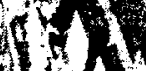
if

1010

$1 / 1 / 1,1$

If
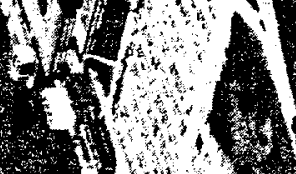

46

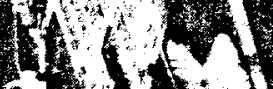

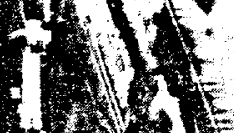

(1)

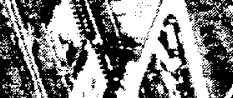

W/ $/ \mathrm{k} / \mathrm{s}$

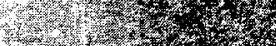

17.

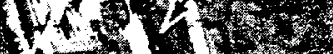

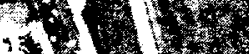

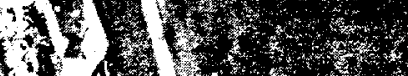

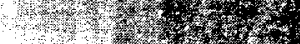

13.

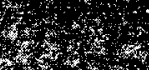

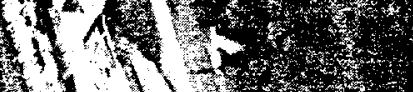

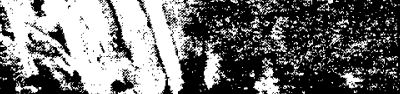




\subsection{REFERENCES}

1. D. A. Webster, A Review of Hydrologic and Geologic Conditions Related to the Radioactive Solid-Waste Burial Grounds at Oak Ridge National Laboratory, Tennessee, U.S. Geologic Survey open-file report $76-727,1976$.

2. F. C. Fitzpatrick, Dak Ridge National Laboratory Site Data For Safety Analysis Reports, ORNL/ENG/TM-19, December 1982. 


\section{FACILITY AND PROCESS DESCRIPTION}

\subsection{CHARACTERIZATION OF THE WASTE}

\subsubsection{Waste Sources}

Solid waste disposal was initiated at ORNL primarily for the purpose of disposing of internally generated contaminated waste; however, as early as 1944, records indicate that waste was being recelved from other organizations involved with the Manhattan project. Shipment of waste in quantity to ORNL continued until, in the late 1950 s and early 1960s, externally generated waste comprised on the order of one half of all waste buried.

Currently, ORNL and other affiliated institutions and facilities within the Oak Ridge Area such as the K-25 Gaseous Diffusion Plant, the Y-12 Plant, Dak Ridge Associated Universities (ORAU), and the Comparative Animal Research Laboratory (CARL) are the largest contributors to the SWSAs. Infrequently, waste is still accepted from other off-site generators but only by special arrangement with ORNL and the Department of Energy.

Little information is available to identify the composition of the early ORNL solid waste. Records are scarce, and the records which are available supply little useful information due to the cloak of secrecy which existed at that point in the Laboratory's history. One can assume that the bulk of the waste was probably not significantly different from the current heterogeneous mixture of items such as laboratory apparatus, wiping materials, filter media, protective apparel, scrap metal and wood, and miscellaneous equipment. Frequently, large volumes of structural materials such as wood and metal framing and siding and concrete have been disposed of in the SWSAs. In other cases, larger pieces of equipment such as tanks and even vehicles have been interred. In the early years of operation, it was not uncommon to receive containers of liquid and sludge materials; but this practice was discontinued. In more recent years, animal waste from biological research has also been added to the diversity. 
Activity of the buried waste is generally low but is difficult to quantify particularly for the earlier waste. All common isotopes such as uranium, thorium, strontium, cesium, plutonium, radium, and tritium can be found in various quantities within the waste. The major exception to this is the waste accepted since october 1970 which contains transuranic isotopes. Since that date, all waste defined as TRU waste (currently $>10 \quad \eta \mathrm{Ci} / \mathrm{g}$ ) has been segregated and placed in retrievable storage facilities designed to allow future removal of the waste for processing and shipment to a permanent repository. It has been estimated that as of 1976, the total long-lived activity in the SWSAs is less than 10,000 curies, exclusive of tritium. ${ }^{6}$

\subsubsection{Waste Types}

The ORNL Solid Waste Management System defines the handling and disposal of waste on the basis of several waste categorles. Waste may be categorized with respect to many parameters such as radionuclide content or physical composition of the host material. In SWSA operation, however, it is convenient to categorize the waste in the manner in which it is generated; i.e., ORNL generated waste, on-site generated waste, or off-site generated waste; in the manner in which it is handled; $i . e .$, routine and nonroutine waste; or on the basis of its radionuclide content and disposal methods; i.e., transuranic (TRU), fissile non-alpha waste, or general radioactive waste (radwaste). In some cases, each of these categories may be further broken down on the basis of beta-gamma radiation levels, on the basis of retrievable or nonretrievable storage, and on the basis of compactability. Figure 4.1 is a flow diagram of ORNL solid waste disposal operations.

ORNL generated waste is that waste produced within the $x-10$ reservation and, in some cases, external to $x-10$ if generated as a result of ORNL programs. On-site waste includes that waste generated in the Oak Ridge Area which is not under the control of ORNL but is within the jurisdiction of $D O E-O R O$. Examples of on-site waste are waste generated by the other Union Carbide Nuclear Division plants, $\mathrm{K}-25$ and $\mathrm{Y}-12$. 
ORNL SOLID RADIOACTIVE WASTE DISPOSAL OPERATIONS

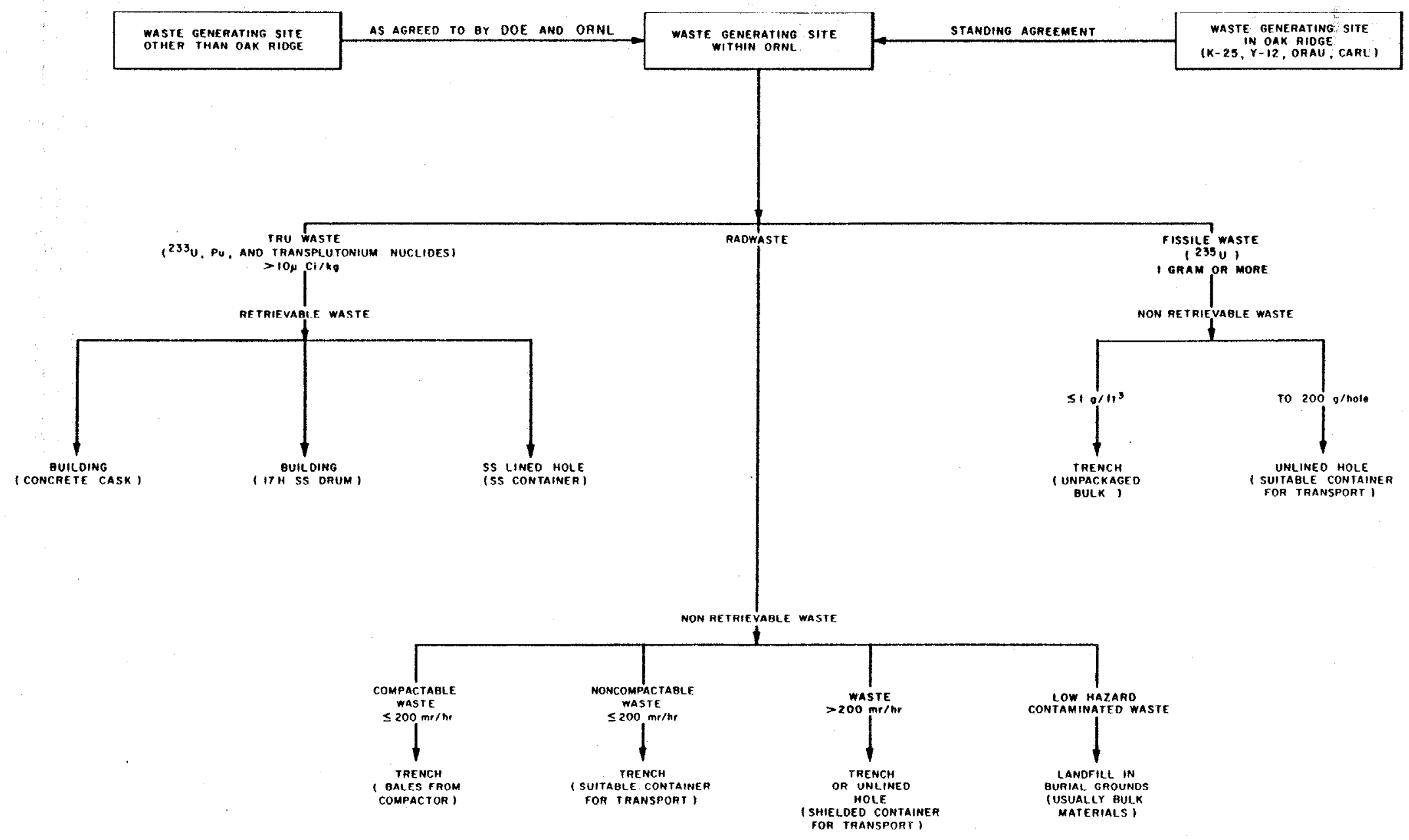

Fig. 4.1. ORNL Solid Radioactive Waste Disposal Operations. 
Off-site waste is generated by other DOE contractors, licensees, or Federal Contractors not in the oak Ridge area and consequently not under the authority of DOE-ORO. Off-site waste is accepted only through mutual agreement with ORNL and DOE-ORO. No distinction is made in the disposal method of either of these waste categories. The major differences are in the transportation requirements for waste from outside ORNL and in the recovery of disposal costs. Both the on-site and off-site generators are responsible for transportation of their waste to ORNL and are charged for the cost of handling and disposing of the material. Specific responsibilities and practices for handing these three types of waste will be discussed in Section 7.2, Operating Practice and Procedure.

Any of the above three categories may be classified as routine or nonroutine. Routine waste is defined as "those repetitive shipments of waste for which procedures have been prepared and/or which mect package content requirements and surface radiation limits or radioactivity with sufficient consistency that they represent no significant hazard in handling/disposal/storage operations." 3 Most ORNI generated wastes fall into this category and are handled in accordance with standard practices and procedures.

Nonroutine waste is that waste which presents some unique problem due to radionuclide content, shape, size, dose rate, etc. and cannot be assured of proper handling under standarl practices and procedures. Each case of nonroutine waste requires special consideration and, in some cases, special procedures are required and/or safety conmittee reviews are necessary prior to disposal of the waste.

Al1 routine and nonroutine, ORNL, on-site, and off-site generated waste is segregated, depending on the radionuclide content, into transuranic waste, fissile waste, or radwaste. Transuranic waste, as defined in DOE order 5820 (Manual Chapter 0511) is all waste contaminated above a specified limit with isotopes of atomic number greater than uranium (transuranic) and including the isotope ${ }^{233} \mathrm{U}$. The current specified Iimit is greater than $10 \mathrm{nCi} / \mathrm{g}$ for any of the transuranic isotopes. This waste is generally fissile and contains long-lived alpha emitters. 
As mentioned previously, since October 1970 all transuranic waste has been stored in special facilities to adequately contain the longlived isotopes and allow for the future removal of the waste if desired. Only transuranic waste is placed in retrievable storage facilitles and thus transuranic waste and retrievable waste is synonymous. Frequently this waste exhibits high beta-gamma radiation background levels and adequate shielding must be provided during handling, packaging, transporting, and storing. Currently, most transuranic waste is generated by three facilities at ORNL, the Transuranium Research Laboratory (Building 5505), the 3019 Pilot Plant, and the Transuranium Processing Plant (Building 7920). It should be observed that much of the waste generated prior to October 1970 is also transuranic by the current definition; however, no attempt was made to retrievably store this type waste prior to that date.

Waste is classified as fissile when it contains either one gram or more of nontransuranic fissionable isotopes or exceeds a concentration of one gram of these isotopes per cubic foot of waste. (Transuranic waste is also generally fissile but is not specifically identified as such.) Most all fissile waste generated at ORNL is contaminated with the isotope $235 \mathrm{U}$. Fissile waste is not required to be stored retrievably as is the transuranic waste. The major concern with the fissile waste is in maintaining a sufficiently low concentration of fissionable material to prevent the possibility of criticality within the waste. The fissile waste is buried, nonretrievably, in unlined auger holes with due regard for both the specific concentration of fissile isotopes in the waste and also the total quantity of fissile material in a given auger hole. Waste containing one gram or more of fissile material but whose physical size prevents burial in a standard auger hole may be handled in one of two ways. If the fissile concentration of the waste is less than or equal to one gram per cubic foot, the waste may be disposed of in a trench with normal radwaste. If the fissile concentration is greater than one gram per cubic foot, the auger hole concept will be applied by excavating a hole large enough to accomodate the waste and 
following the proceduras for auger hole disposal. In both cases, the waste would be treated as nonroutine waste and would be subject to special procedures and/or comittee reviews.

General radioactive waste, or radwaste, is basically any waste which is not categorized as transuranic or fissile waste. General radwaste will contain varying amounts of beta-gamma emitting isotopes and possibly small amounts of nonfissionable alpha activity such as $238_{\mathrm{U}}$. Radwaste is defined as low-level radwaste or high-level radwaste on the basis of its beta-gamma radiation background. Low-level radwaste exhibits a radiation level of $200 \mathrm{mrem} / \mathrm{h}$ or less at the surface of the unshielded package or container. High-level radwaste exhibits greater than $200 \mathrm{mrem} / \mathrm{h}$ at the surface of the unshielded container. Low-level radwaste is generally disposed of in trenches and high-level radwaste is generally disposed of in unlined auger holes with increased consideration for radiation exposure during transport and disposal. In some cases, high-level radwaste may be categorized as nonroutine waste and external shielding or a shielded carrier may be required.

Low-level radwaste is further segregated into compactible and noncompactible waste. Compactible waste is dry waste consisting of basically compressible materials such as plastic bags and plastic bottles, paper, rubber and cloth gloves, shoe covers, or rags. Noncompactible waste is either slightly wet waste such as mop heads or rigid structural materials such as wood, pipe, metal angle and frames, or heavy glass bottles and containers. Wastes which are considered compactible are separated at the point of origin by the generator and sent to the Waste Compactor Facility for volume reduction before disposal. Only low-level radwaste is compacted at the compactor facility. Transuranic waste, fissile waste, or high-level radwaste are never compacted prior to disposal.

Some solid waste which has no measurable contamination as determined by radiation survey but is judged by the generator to have contamination potential due to its history is classified as low-hazard contaminated waste. Most low-hazard contaminated waste consists of 
construction debris or processing equipment or machinery. This lowhazard material is generally disposed of by normal commercial solid waste landfill techniques in designated areas of the SWSAs.

Combinations of the above categories occur frequently in SWSA operation. For example, transuranic waste may be fissile; or fissile waste may be largely beta-gamma radwaste. Mixed waste is always handled with regard to the most sensitive component which it contains. For example, all transuranic waste will be stored retrievably regardless of the remainder of the composition. All waste containing greater than one gram total or one gram per cubic foot of fissile material will be stored as fissile waste unless the waste also contains transuranics, In which case it would be stored in a retrievable facility with due consideration for the criticality problem. Only waste not exceeding the specified limits for both transuranic and fissile waste would be handled as general radioactive waste.

\subsubsection{Waste Collection and Packaging}

Waste collection and packaging prior to transport for disposal is primarily the responsibility of the waste generator. The generator collects the waste, completes radiation surveys as necessary, segregates the waste in accordance with the previously discussed categories, completes any necessary decontamination, and finally packages the waste in an approprlate and acceptable form for disposal. Industrial Safety and Applied Health Physics personnel are responsible for radiation surveys and for spot verification of appropriate waste segregation and packaging. When these steps have been completed, SWSA personnel will pick up and assume responsibility for the waste either by specific request from the generator or by routine scheduled pickup. SWSA personnel transports the package to the SWSA and disposes of the waste in the appropriate manner. The detailed responsibility and procedure for these operations will be discussed in further detall in Section 7. 
Rigid procedures have been developed for the packaging of solid waste. The ORNL Health Physics Procedure Manual, Chapter 5.1, lists acceptable containers to be used for each waste category (Table 4.1). Waste received at the storage areas which has not been properly packaged will be returned to the generator for repackaging. In addition to proper packaging and segregation, the waste must also be accompanied by certain forms supplying necessary information for ORNL SWSA records. The required forms indicated in Table 4.1 are discussed in detail in Section 7 .

Low-level radwaste is normally disposed of in conventional waste can type containers designated by appropriate marking for contaminated waste (Fig. 4.2). These containers, sometimes known as "hot cans," are Ined with plastic bags to facilitate emptying and to protect the container interior against contamination. Compactible and noncompactible waste is placed in separate containers. When the container is full or is determined by the area supervisor to be ready for removal, the bag is securely closed and placed in a collection dumpster. If the container holds compactible waste, it is closed and tagged to show date, source (building and room number), principle radioisotopes present, any special hazards, and the originator. The container is then reused by inserting a new plastic bag. Periodic checks by Health Physics personnel ensure that the container remains below acceptable contamination levels. If the container does become contaminated above the acceptable limits, it is either cleaned or disposed of.

In some cases, it may be necessary or desirable to place low-level waste in disposable containers (Fig. 4.3). Disposable containers are normally used for materials containing higher levels of activity or heavy or sharp objects which could puncture plastic bags. These contalners are available from ORNL stores in various capacities from 1 to 20 gallons. Waste placed in these containers is normally removed from the work area as soon as possible. 
Table 4.1. Radioactive solid waste disposal schedule

\begin{tabular}{|c|c|c|c|}
\hline Waste category & $\begin{array}{l}\text { Approval or } \\
\text { form required }\end{array}$ & $\begin{array}{l}\text { Type } \\
\text { container }\end{array}$ & $\begin{array}{l}\text { Disposal or } \\
\text { storage site }\end{array}$ \\
\hline $\begin{array}{l}\text { General high-level radioactive } \\
\text { waste (beta-garna }>200 \mathrm{mrem} / \mathrm{h} \\
\text { at the surface of unshielded } \\
\text { container) }\end{array}$ & UCN-2822 & $\begin{array}{l}\text { Closed plastic; } \\
\text { closed can; } \\
\text { shielded cask; } \\
\text { shielded yellow } \\
\text { Dumpster; } \\
\text { "hot" truck }\end{array}$ & $\begin{array}{l}\text { SWSA- } 6 \text {, in auger } \\
\text { hole or trench }\end{array}$ \\
\hline $\begin{array}{l}\text { General low-level radioactive } \\
\text { waste (beta-gamma } \leq 200 \mathrm{mrem} / \mathrm{h} \text { ) }\end{array}$ & UCN-2822 & $\begin{array}{l}\text { Plastic bag; } \\
\text { fiber carton } \\
\text { yellow can; } \\
\text { walk-in yellow } \\
\text { Dumpster }\end{array}$ & $\begin{array}{l}\text { SWSA-6, in trench } \\
\text { (after compaction } \\
\text { in SWSA-5) }\end{array}$ \\
\hline $\begin{array}{l}\text { Genera1 low-1eve1 radioactive } \\
\text { noncompactible waste (beta- } \\
\text { garnma } \leq 200 \mathrm{mrem} / \mathrm{h} \text { ) }\end{array}$ & UCN-2822 & $\begin{array}{l}\text { Plastic; } \\
\text { fiber carton; } \\
\text { yellow can; } \\
\text { yellow Dumpster; } \\
\text { "hot" truck. }\end{array}$ & SWSA-6, in trench \\
\hline $\begin{array}{l}\text { Transuranic waste } \\
(>10 \mathrm{nCi} / \mathrm{g} \text { TRU } / 233 \mathrm{U}) \\
(<200 \mathrm{mrem} / \mathrm{h} \text { beta-gamma })\end{array}$ & $\begin{array}{l}\text { UCN-2822 } \\
\text { UCN-2681 }\end{array}$ & $\begin{array}{l}\text { Sealed stainless } \\
\text { drum }(17 \mathrm{H}) \\
\text { sealed concrete } \\
\text { cask }\end{array}$ & $\begin{array}{l}\text { SWSA-5, in building } \\
\text { or trench }\end{array}$ \\
\hline $\begin{array}{l}\text { Transuranic waste } \\
(>10 \mathrm{nCi} / \mathrm{g} \text { TRU/233 } \mathrm{U}) \\
(>200 \mathrm{mrem} / \mathrm{h} \text { beta-gamma })\end{array}$ & $\begin{array}{l}\text { UCN-2822 } \\
\text { UCN-2681 }\end{array}$ & $\begin{array}{l}\text { Sealed concrete } \\
\text { cask; } \\
\text { sealed special } \\
\text { container }\end{array}$ & $\begin{array}{l}\text { SWSA-5, in lined } \\
\text { auger hole or trench }\end{array}$ \\
\hline
\end{tabular}


Table 4.1. (continued)

\begin{tabular}{|c|c|c|c|}
\hline Waste category & $\begin{array}{l}\text { Approval or } \\
\text { form required }\end{array}$ & $\begin{array}{l}\text { Type } \\
\text { container }\end{array}$ & $\begin{array}{l}\text { Disposal or } \\
\text { storage site }\end{array}$ \\
\hline $\begin{array}{l}\text { Fissile waste } \\
\left(>1 \mathrm{~g} \text { total or }>1 \mathrm{~g} / \mathrm{ft}^{3}\right)\end{array}$ & $\begin{array}{l}\mathrm{UCN}-2822 \\
\mathrm{UCN}-2681\end{array}$ & $\begin{array}{l}\text { Closed package; } \\
\text { bulk }\end{array}$ & $\begin{array}{l}\text { SWSA- } 6 \text {, in unlined } \\
\text { auger hole or trench }\end{array}$ \\
\hline $\begin{array}{l}\text { Mixed wastes } \\
\text { (combinations of those } \\
\text { listed above) }\end{array}$ & $\mathrm{UCN}-2822$ & Governed by types & $\begin{array}{l}\text { Governed by wastes } \\
\text { present }\end{array}$ \\
\hline $\begin{array}{l}\text { Low hazard contaminated waste } \\
\text { (waste with no measurable con- } \\
\text { tamination by radiation survey } \\
\text { but judged by the generator, } \\
\text { because of its history, to be } \\
\text { radioactively contaminated above } \\
\text { "green tag" limits, hence unsuit- } \\
\text { able for release from Waste } \\
\text { Management control) }\end{array}$ & UCN-2822 & $\begin{array}{l}\text { Plastic can; } \\
\text { Dumpster; } \\
\text { truck }\end{array}$ & SWSA-6 \\
\hline
\end{tabular}




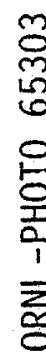

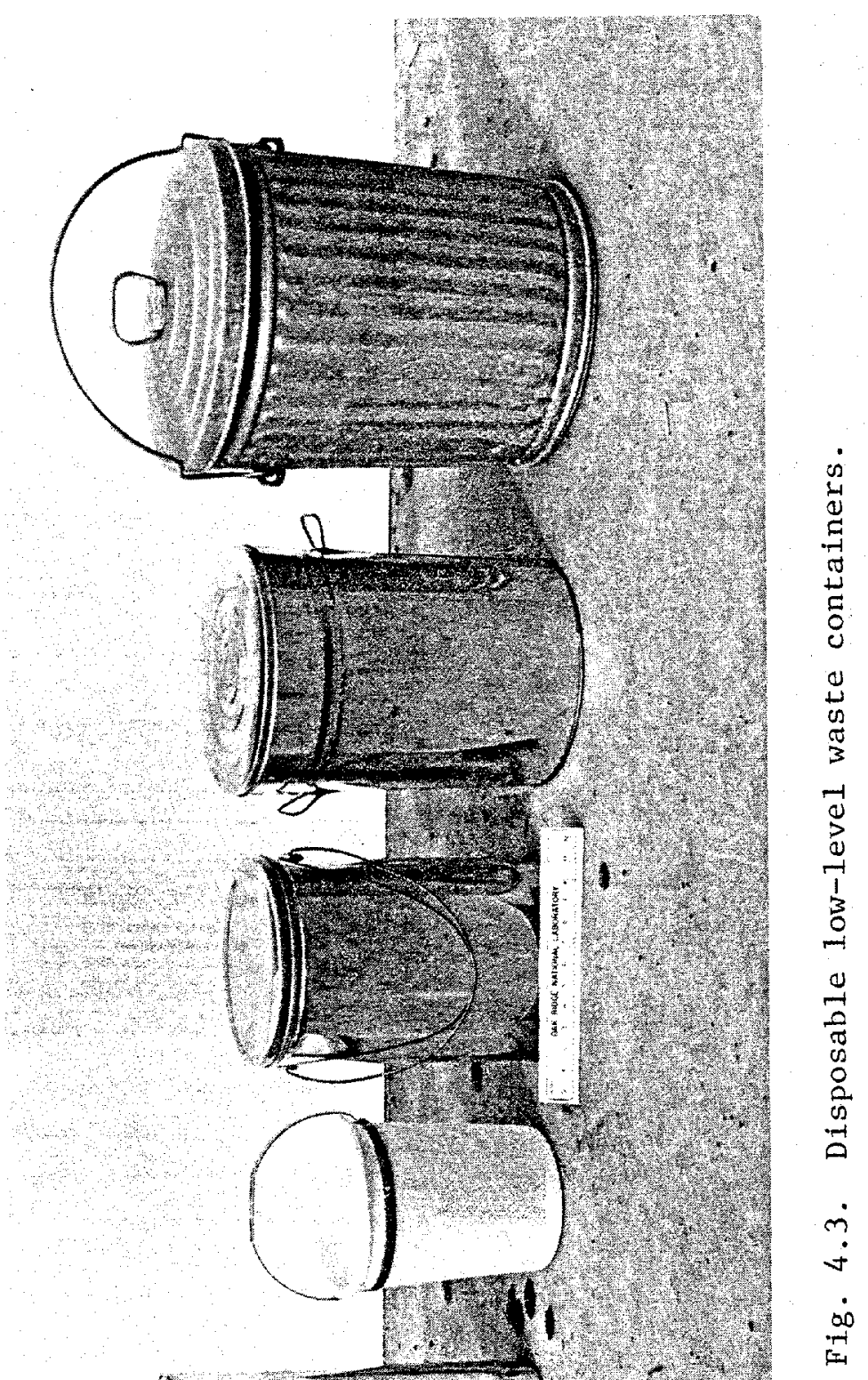


All sorting of compactible and noncompactible waste is accomplished by the generator at the time of packaging. Table 4.2 gives some examples of compactible and noncompactible waste and the acceptable container types for each. Compactible waste is normally packaged in plastic bags, but other containers may be acceptable as long as the container itself is also easily compactible.

Locked waste collection dumpsters (yellow - Fig. 4.4) are provided In most areas for collection of low-level waste packages. Separate dumpsters are provided for compactible and noncompactible waste. All wastes are packaged in one of the container types mentioned above prior to being placed in a dumpster. All compactible waste packages are tagged and the dumpsters are kept locked. The local Health Physics Surveyor holds the key to the locked dumpsters and observes transfers into the dumpsters. If dumpsters are not available in a particular area, special arrangements will be made by SWSA personnel to collect the waste. A special truck periodically picks up the dumpsters and transports them to the SWSA where the waste is either dumped into a trench or removed and compacted. The dumpster is then returned to its original location.

General high-level radloactive waste is packaged in a manner which provides sufficlent shielding for transport to the SWSA. Most high-level radwaste is generated in hot cells or other special control areas. Arrangements are made to provide proper shielding before the material is removed from the controlled area. Bottom discharge carriers (Fig. 4.5) are normally used to transport high-level radwaste. If a shielded carrier is used, the waste is packaged in another container (Fig. 4.3) before being placed in the carrier. The carrier is then transported to the SWSA and the container holding the waste is lowered by an attached wire or cable into the storage hole or trench. 
Table 4.2. Examples of compactible and noncompactible contaminated waste and acceptable containers

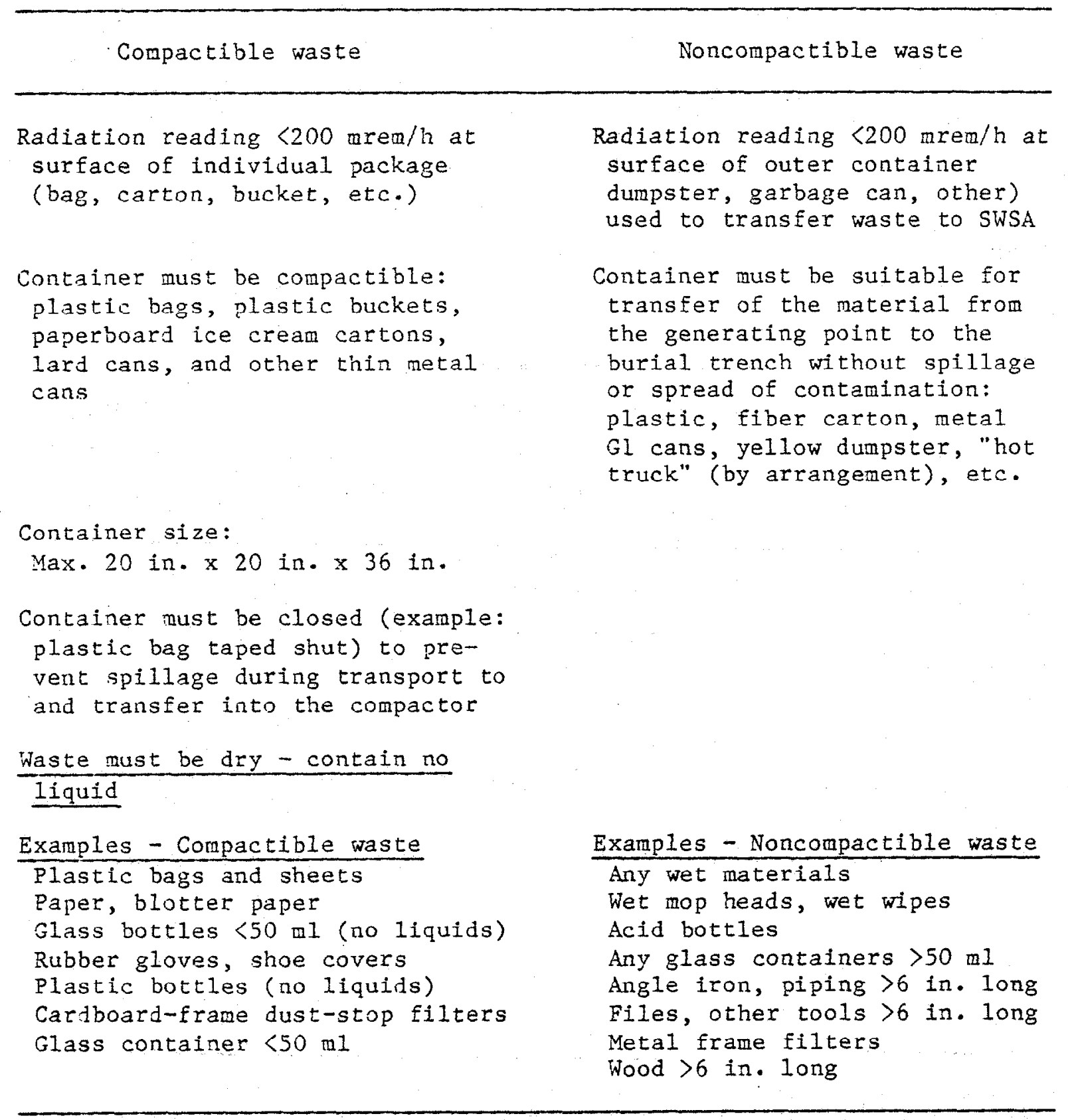




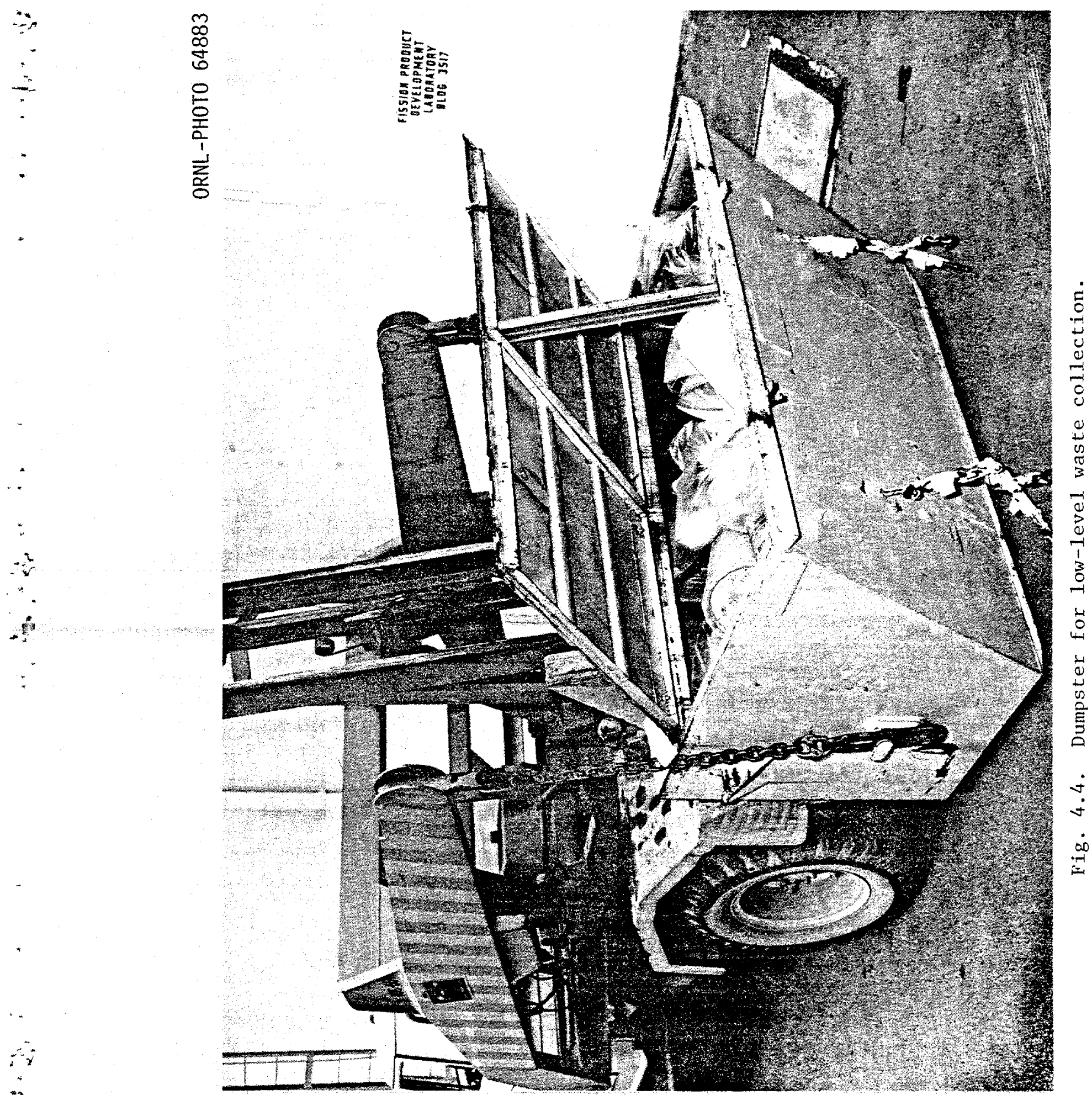




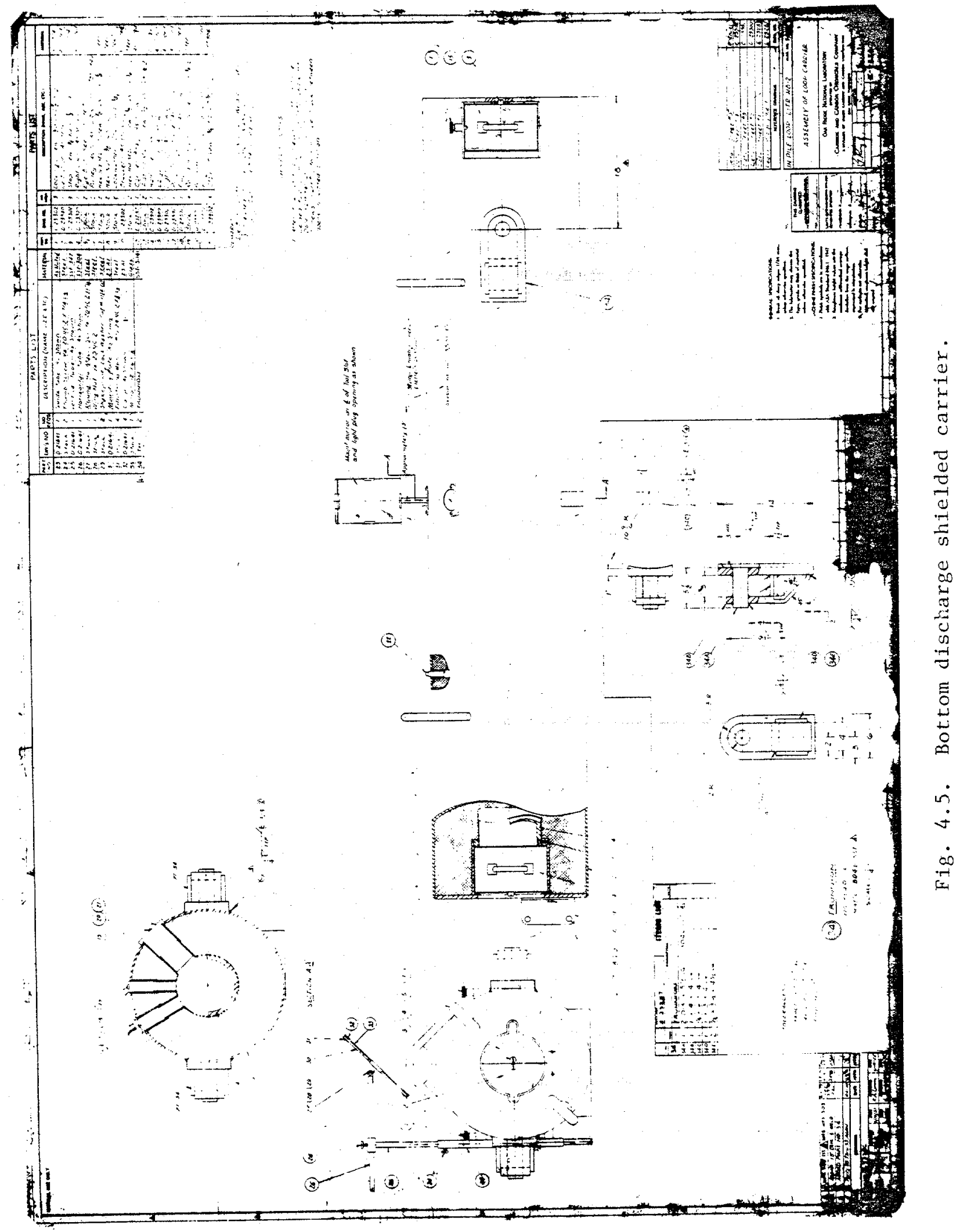


In some cases involving more routine generation of high-level radwaste, lead shielded dumpsters (Fig. 4.6) are used for temporary storage and transport of the waste. Shielded transport trucks may also be used for high-level waste transportation if the situation requires them (Fig. 4.7). High-level radwaste is not compacted; and therefore, segregation is not required.

All waste from glove boxes and hot cells where work is being done on pure beta emitters are defined as high-level radwaste due to the difficulty of detection. For these wastes, double packaging is required to prevent the possibility of a container rupture during transport to the SWSA. These wastes also are not considered for compaction but go straight to burial.

The requirement for the retrievability of all currently generated transuranic waste places special restrictions on the packaging of the waste. There are three basic types of containers used for transuranic waste with the selection among the three based on the radiation level of the particular waste. The three containers are stainless steel drums, concrete casks, and sealed stainless steel canisters of various shapes and sizes.

Low-level transuranic waste is placed in stainless steel drums which in turn are placed in a retrievable storage facility (see section 4.4). The drums (Fig. 4.8) are available in 30- and 55-gallon capacities and are designed and built in accordance with Department of Transportation (DOT) specification $17 \mathrm{H}$. The drums are sealed with a gasket and compression ring arrangement. Each drum is tagged by the originator with such information as date, source, principle radioisotopes present, special hazards, and the originator. This information is later transferred to a stainless steel tag which is permanently attached to the drum. The drums are sent temporarily to a staging facility (see section 4.4) and eventually to the retrievable storage facility where they are kept indefinitely. 


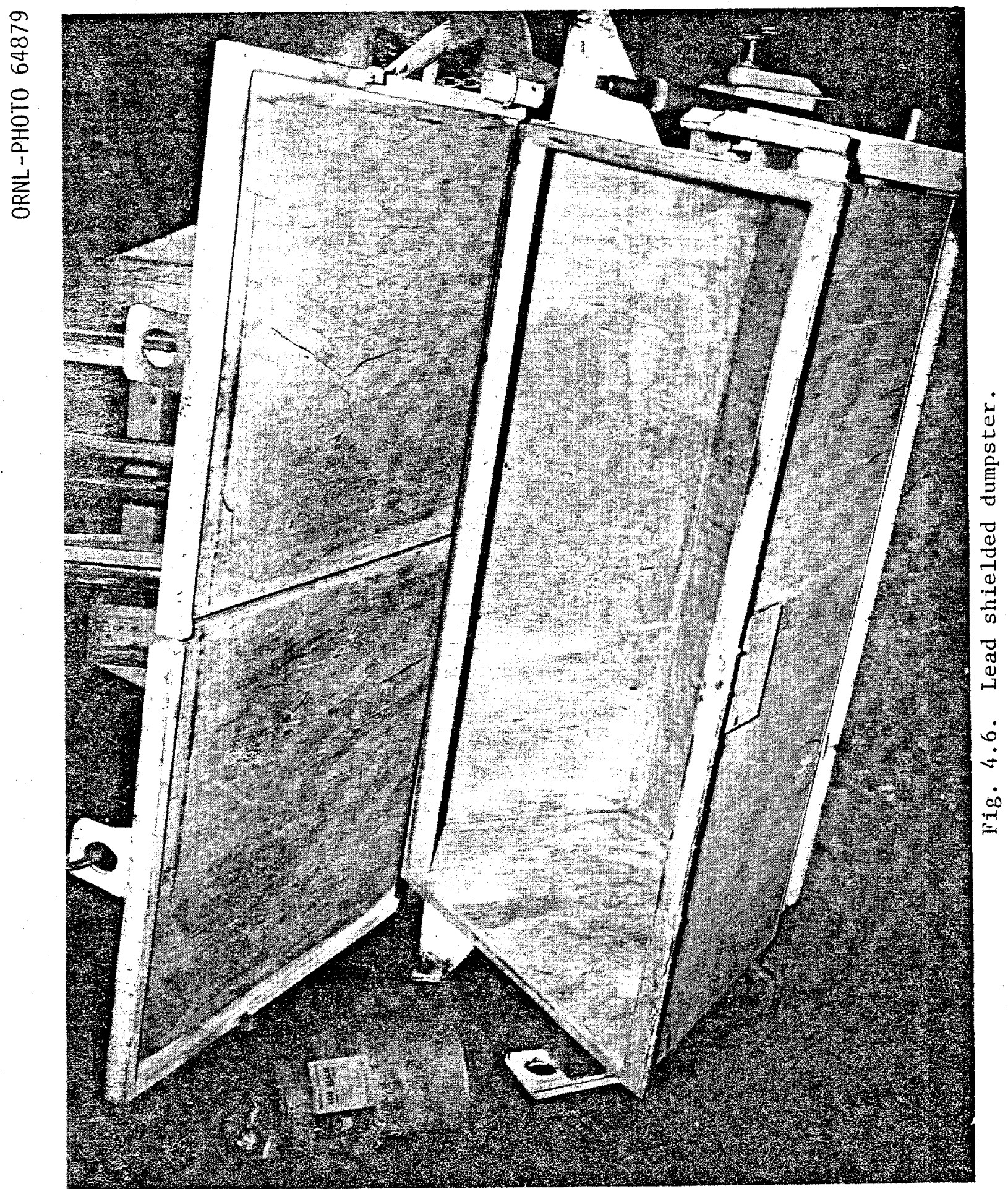



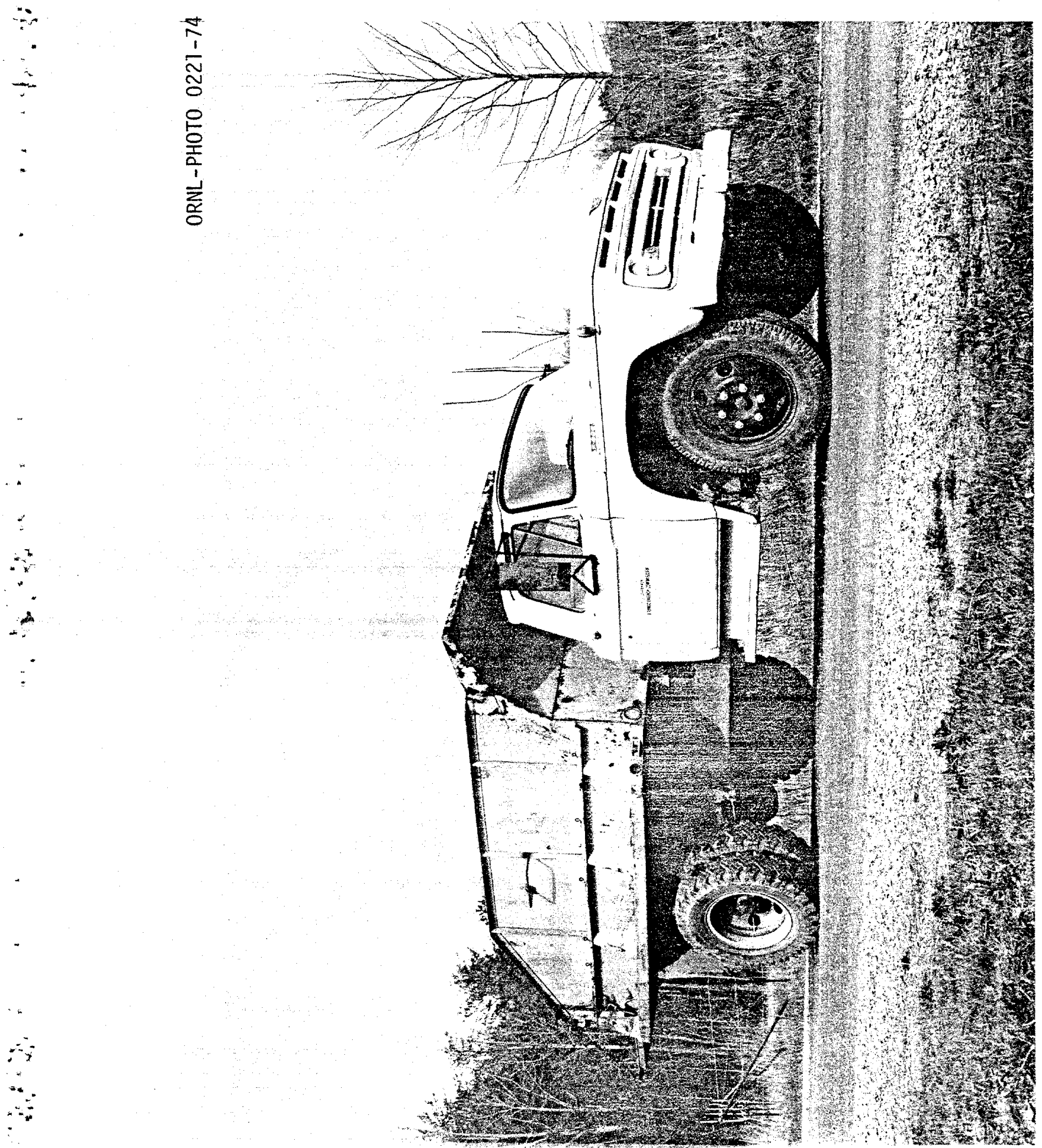

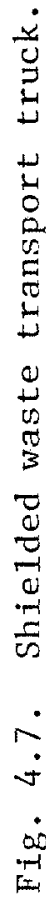




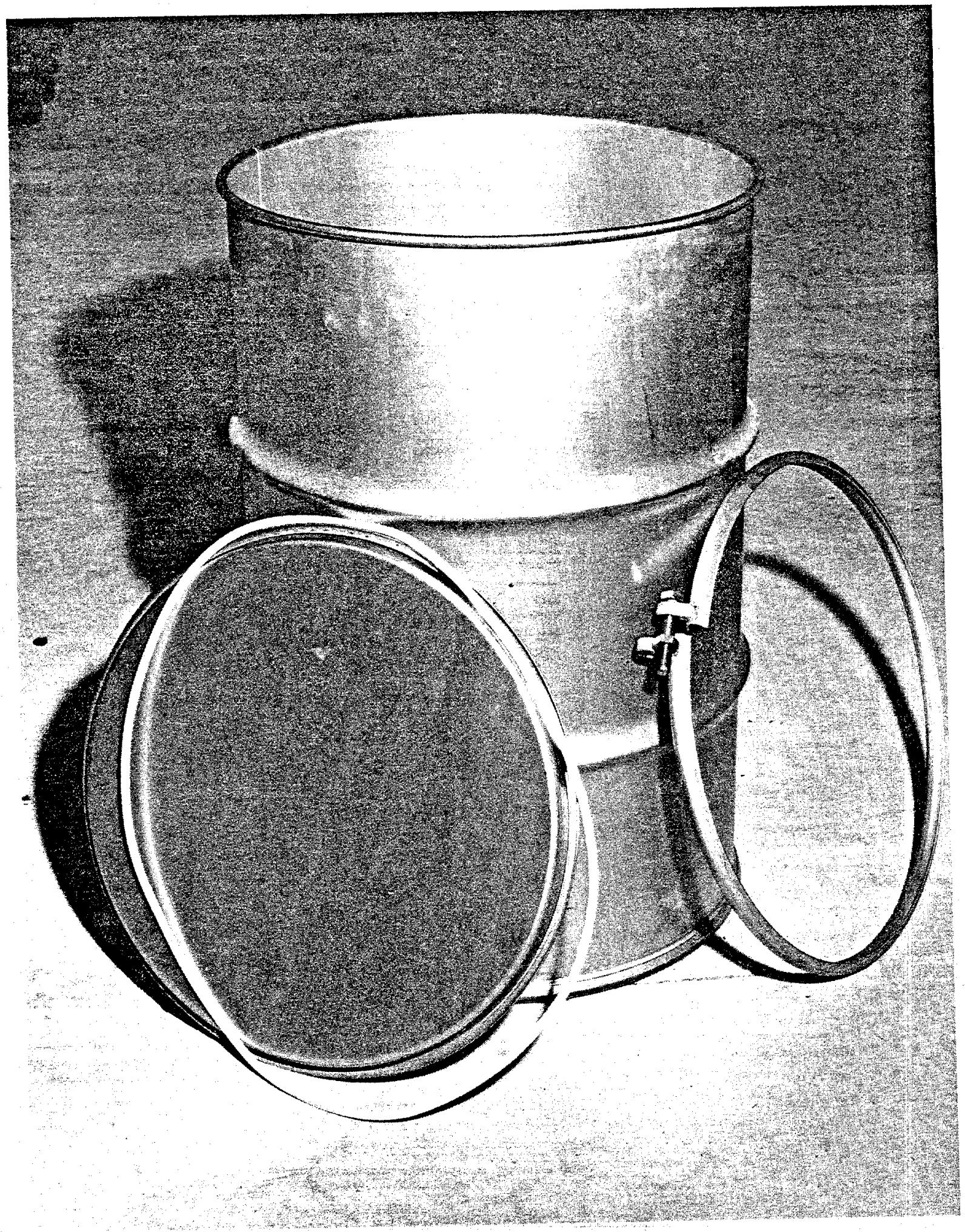

Fig. 4.8. Stainless steel retrievable storage drum and closure hardware. 
Transuranic wastes with higher beta-gamma backgrounds ( $>200$ $\mathrm{mrem} / \mathrm{h}$ ) which require shielding are stored in concrete casks. These casks (Figs. 4.9, 4.10, and 4.11) have been designed in three wal1 thicknesses: $41 / 2,6$, and $12 \mathrm{in.}$ The casks are currently available only in the 6- and 12-in sizes. The cask chosen depends entirely on the amount of shielding necessary for the particular waste. The casks are approximately $41 / 2$ feet in diameter by 7 -ft tall. Waste is placed in the casks by the generator and the cover is sealed using a tar type caulking material. The casks are transported to the SWSA and are currently disposed of in a special concrete storage facility (see Section 4.4). In the past, the casks were buried in speclal trenches, in some cases with a concrete overburden.

Transuranic wastes exhibiting extremely high beta-gama backgrounds are sealed in stainless steel containers prior to transport. These containers (Fig. 4.12) may either be fully welded construction or may have a bolted cover. Each container is fabricated to the required dimensions for a specific disposal problem and has a stainless steel cable permanently attached for lifting purposes. The containers are placed in a shielded carrier and transported to the SWSA where they are lowered into a stainless steel lined auger hole using the attached cable (Fig. 4.13). The hole, with the cable exposed, is sealed by a concrete stepped plug.

Whenever feasible, transuranic wastes are separated into burnable and nonburnable fractions and are disposed of in separate containers. When this is not feasible, the percentage of burnable material is estimated and indicated on the tag for future reference. All containers are identified as either burnable, nonburnable, or some percent burnable. In either case, handling and disposal of the container remain the same.

Fissile waste is placed in any of the previously described containers, as appropriate, and is disposed of nonretrievably in auger holes or trenches. Container types for mixed waste, as with the disposal method, is determined by the most hazardous material contained in the waste. 


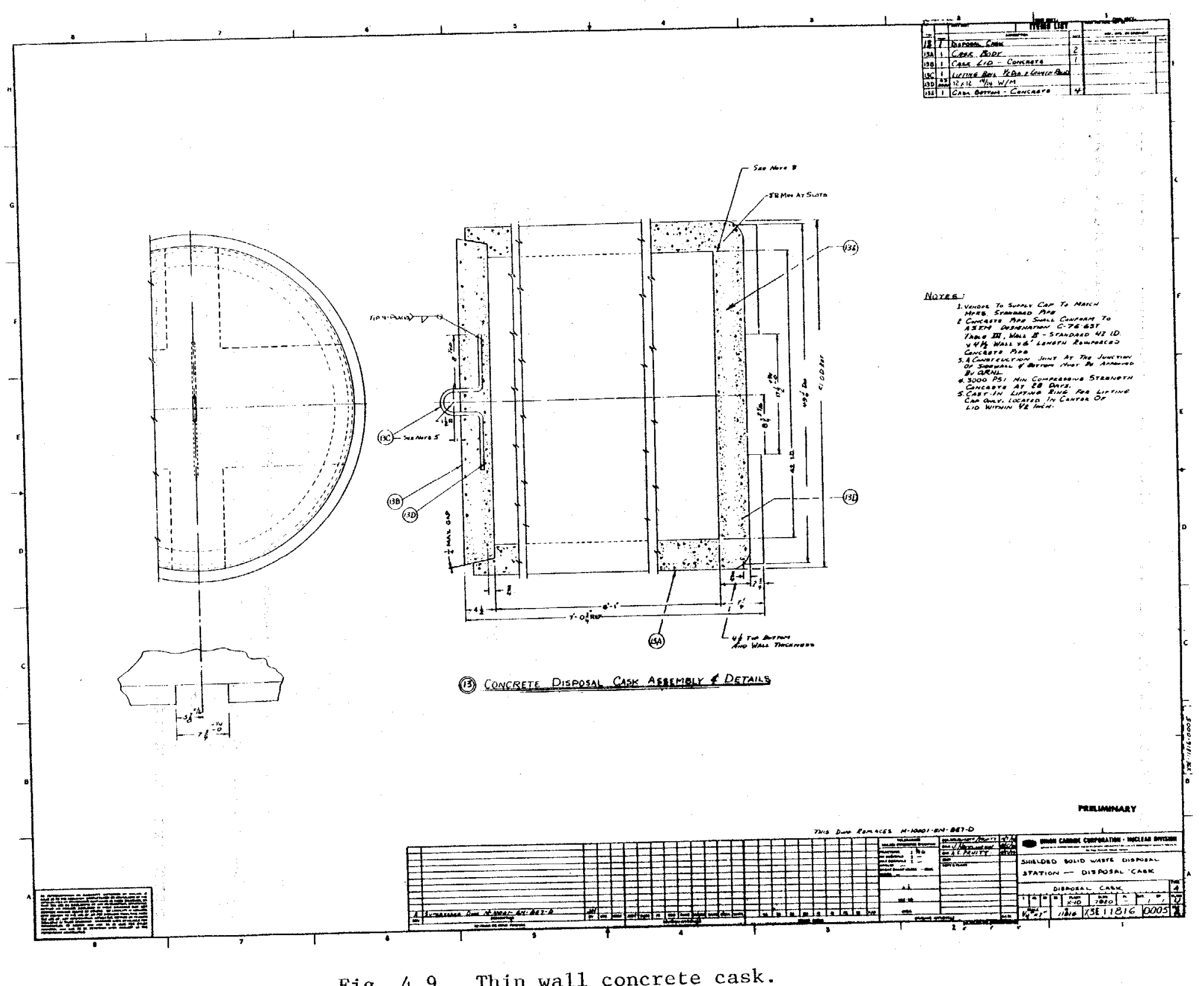

i
N 

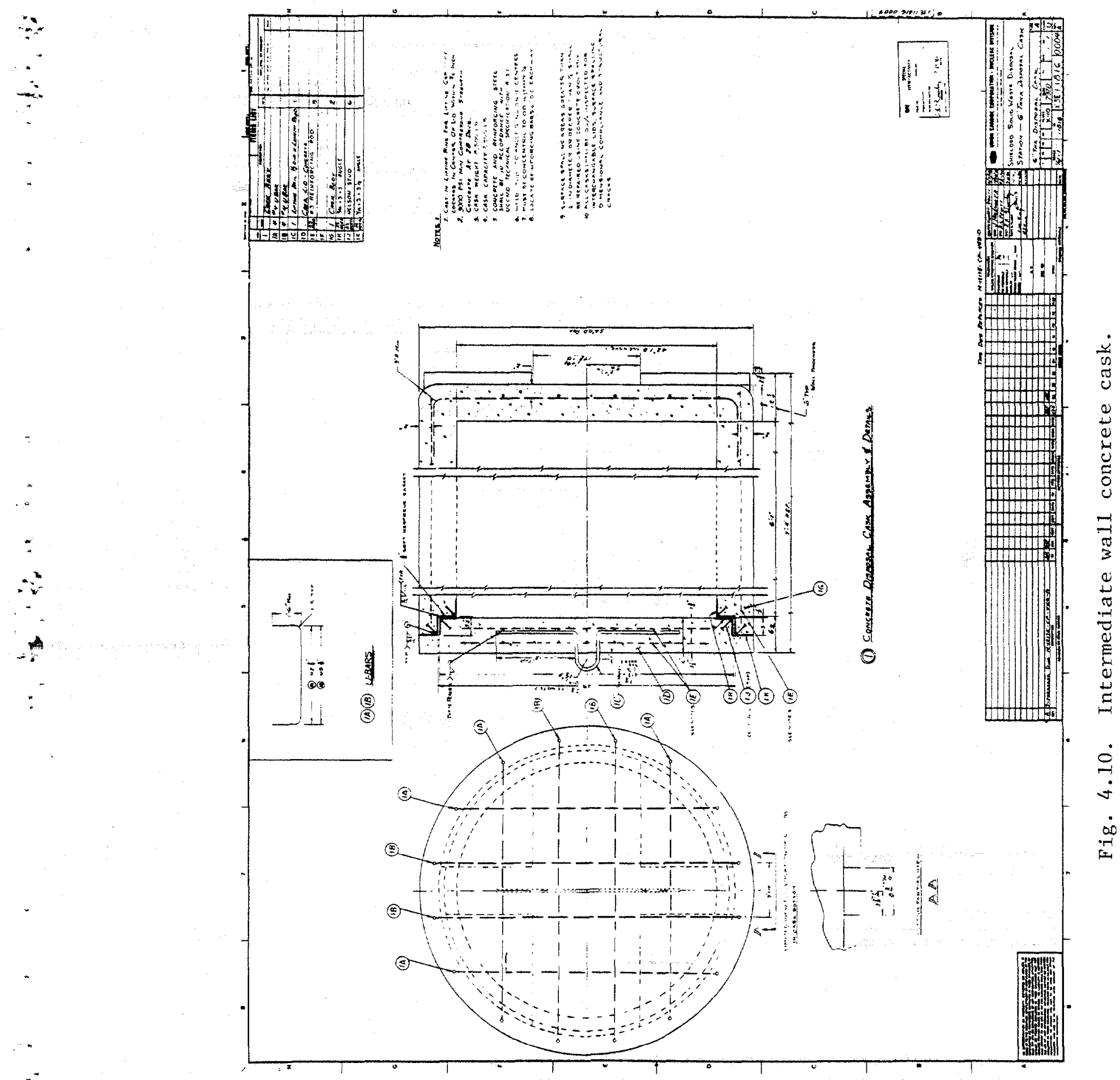


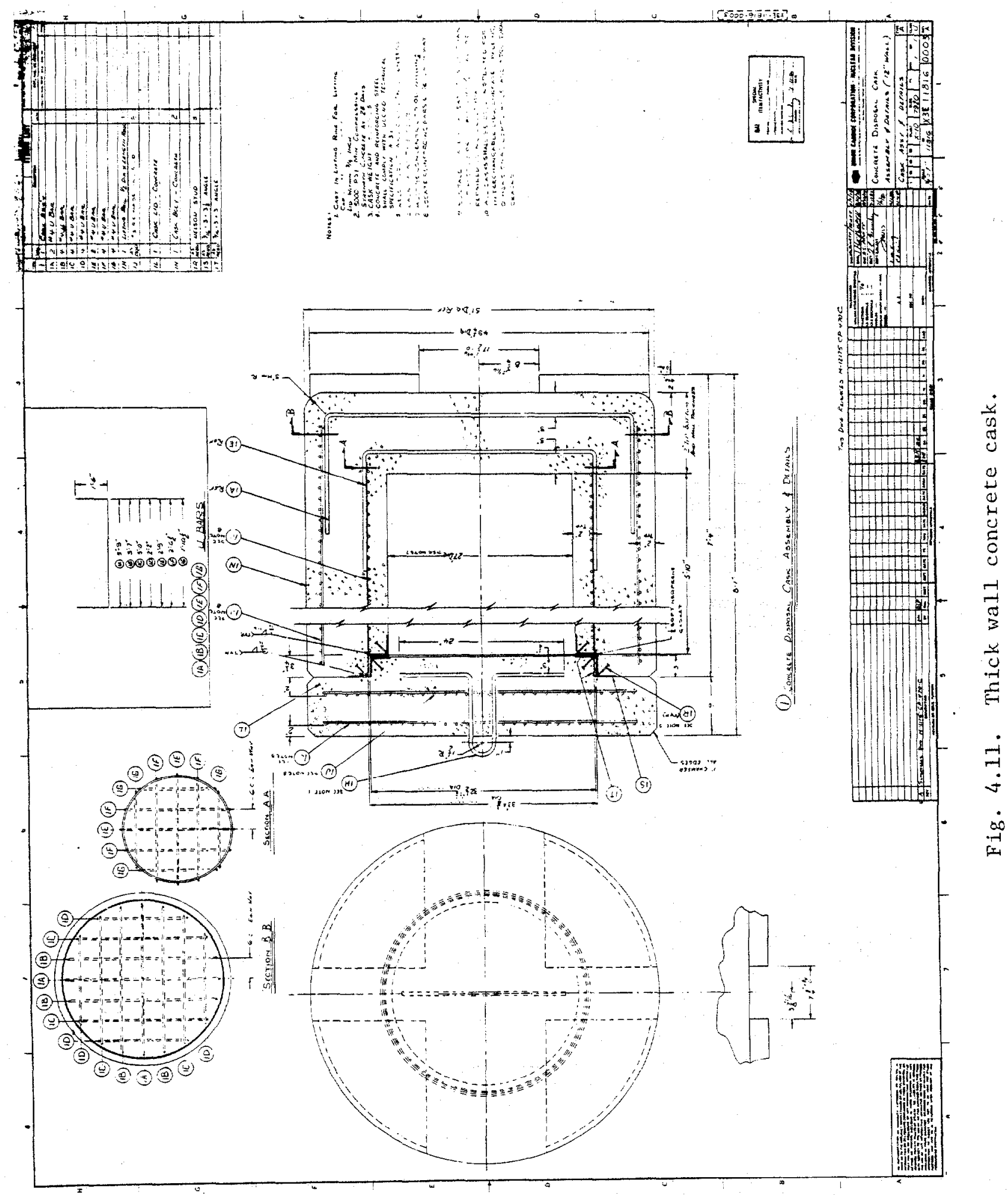




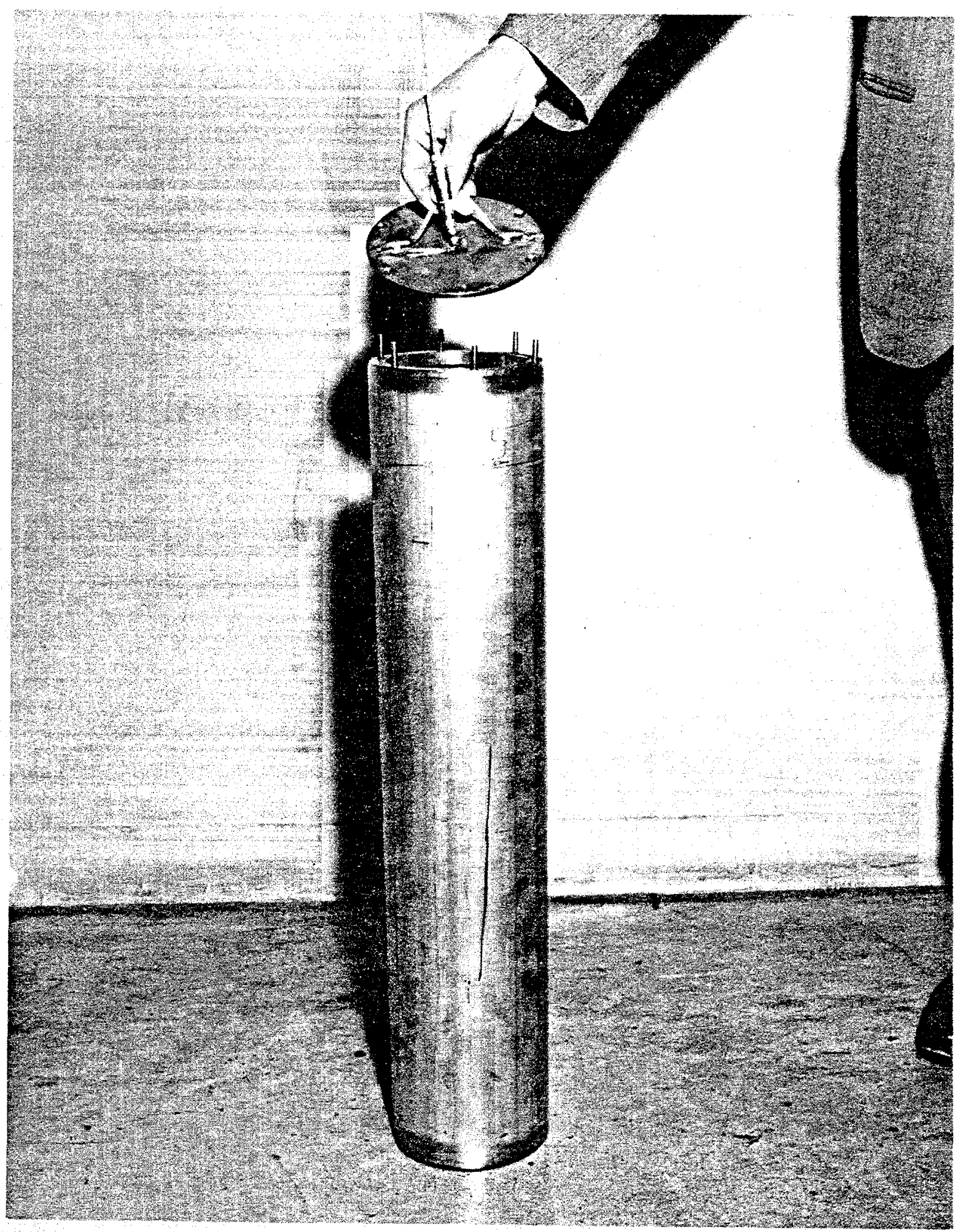

Fig. 4.12. Typical stainless steel high-level retrievable waste container. 


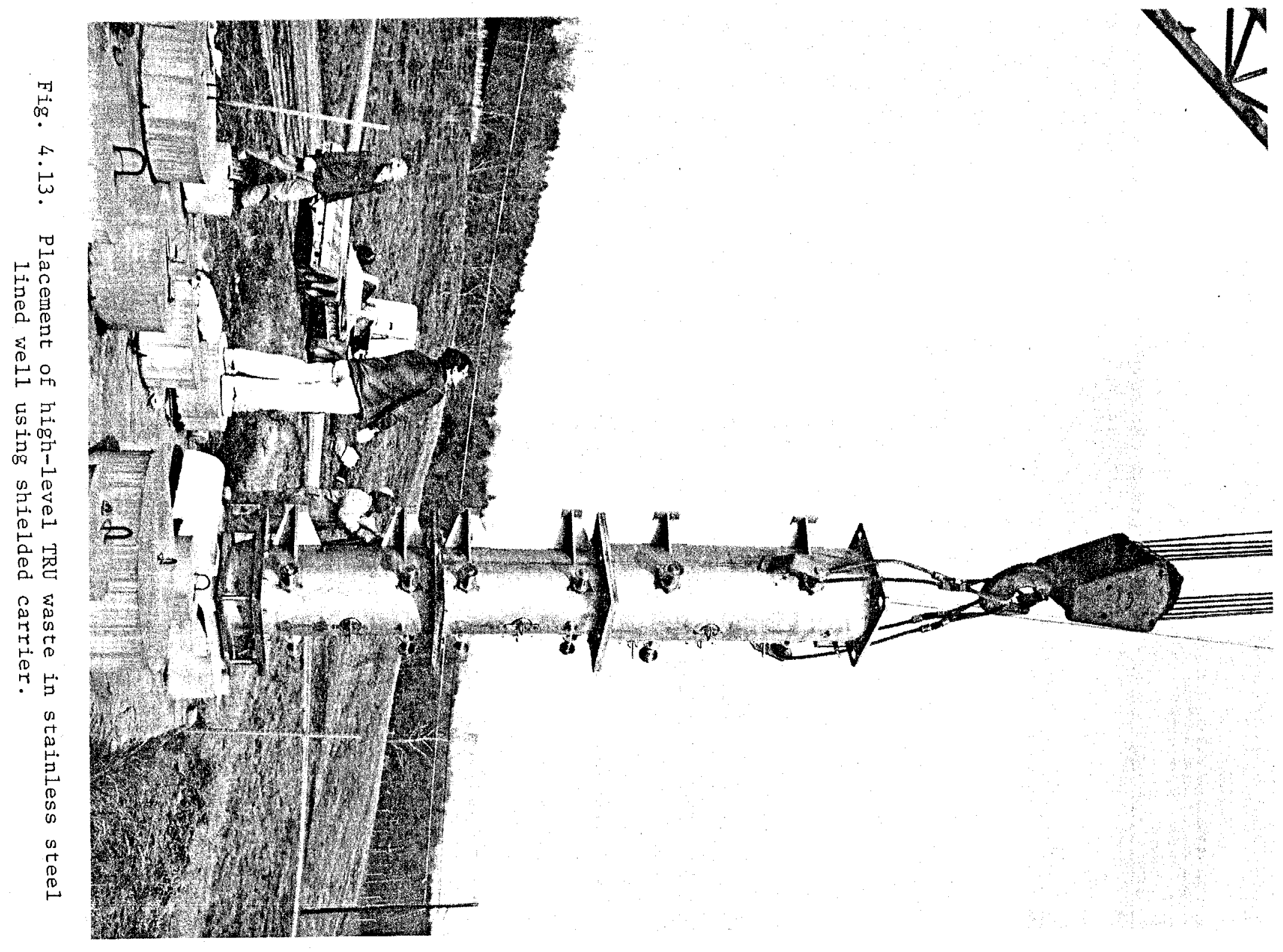




\subsection{SOLID WASTE STORAGE AREAS}

\subsubsection{Introduction}

The problem of radioactive waste disposal arose in the initial stages of the wartime effort when small quantities of radioactive material began to be generated. ${ }^{6}$ The Laboratory, at that time operated by the DuPont Company, recognized early the need for segregation and special disposal procedures for radioactive material and items contaminated with radioactive material. This is illustrated in a memorandum issued in early 1944 suggesting that "a metal trash can with cover, with red lettering on the can, be provided for the disposal of actively contaminated broken glassware or materials not sufficiently clean to be used on other work." The letter further suggested that "a suitable location for the burying of this material could be provided over on the burning ground. A suitable pit with enclosed fence could be made." This pit became the site of the first solid waste burial ground at the Laboratory and initiated a practice which has continued, with numerous refinements, to the present day.

Six different SWSAs have been designated and utilized during the life of the Laboratory. The first three, located in Bethel Valley near the site of the current Laboratory complex (Fig. 3.5), were selected with little knowledge or regard for the mobility of the various isotopes being buried. Selection of sites was instead based on convenience and similar use of the surrounding area, as in the siting of SWSA-1 near the burning ground as illustrated above. The most recent three SWSAs have been sited in Melton Valley to take advantage of certain soil properties which help to immobilize the radionuclides. The first three burial grounds were small and intended to satisfy short term needs for disposal. This is reasonable to expect considering the dedicated mission and anticipated short lifetine of the Laboratory during its early history. The latter three burial grounds were observed as facilities to satisfy the long term needs of a rapidly expanding research and development facility and consequently were much larger, better organized, and better planned. 
Table 4.3 lists each of the SWSAs along with dates of operation and the total area contained in each SWSA. SWSA-1 through -5 are currently closed for normal burial operations. SWSA-3 was used until recently for the above ground storage of reusable equipment but this practice has been discontinued and all material in above ground storage has been removed and disposed of in other areas. SWSA-5 is currently used for the retrievable storage of transuranic waste. Several retrievable storage facilities are located in the northern end of SWSA-5. SWSA-6 is the only SWSA currently open for trench burial of general radioactive waste.

Table 4.3. ORNL solid waste storage areas

\begin{tabular}{ccccc}
\hline SWSA & Operating & Status & Acreage & $\mathbf{m}^{2}$ \\
\hline 1 & $1943-1944$ & closed & 1 & $4 \times 10^{3}$ \\
2 & $1944-1946$ & closed & 4 & $1.5 \times 10^{4}$ \\
3 & $1946-1951$ & closed & 6 & $2.4 \times 10^{4}$ \\
4 & $1951-1959$ & closed & 23 & $9.3 \times 10^{4}$ \\
5 & $1959-$ & operating & 50 & $2.0 \times 10^{5}$ \\
6 & $1969-$ & operating & $68^{2}$ & $2.8 \times 10^{5}$ \\
\hline
\end{tabular}

$1_{\text {Retrievable storage facilities only. Area closed for trench }}$ burial in 1973 .

2 only approximately 14.5 acres is useable based on present practice.

The following sections will describe each SWSA in detail. 


\subsubsection{SWSA-1}

As mentioned previous1y, SWSA-1 was selected due to its proximity to the incineration area in use at that time. The site was located at the southern edge of the main Laboratory area, at the foot of Haw Ridge and about $7.6 \mathrm{~m}(25 \mathrm{ft})$ south of White oak Creek. The site is a triangular shaped area encompassing approximately $4.0 \times 10^{3} \mathrm{~m}^{2}$ (one acre) (Fig. 4.14). Conflicting reports exist as to whether some waste was placed in auger holes at the east end of the site. It is known that only a small number of trenches were excavated before the site was abandoned when water was found in an excavated trench in the northern section of the site. Figure 4.14 is based primarily on memory relayed through oral communication and thus is subject to error. No records were maintained on the burial operations and thus there is no way of knowing the nature or quantity of the materlal buried in the area. Figure 4.15 is a current Laboratory photograph showing SWSA-1. The storage area is now fenced and grassed and maintained as necessary. The access road to the Laboratory's south parking lot passes through the central area of the SWSA. Some surface drainage from Haw Ridge flows across the SWSA in route to White oak Creek. Ground water movement in the area is also into White Oak Creek and is subsequently monitored via the Stream Monitoring System.

\subsubsection{SWSA-2}

SWSA-2 is located on the south side of a hill near the East entrance and main parking area of the Laboratory, northwest of Building 4500. The area is currently unfenced with a grass cover. An access road to a transformer station passes through the SWSA. Figure 4.16 is an aerial view of the site. Figure 4.17 is a diagram of the original site boundaries with respect to current landmarks.

SWSA-2, containing approximately $1.6 \times 10^{4} \mathrm{~m}^{2}$ (4 acres) was opened shortly after the closing of SWSA-1. The area was selected due to its proximity to the graphite reactor and processing facilities to provide easier access to the burial area. Personal interviews have indicated 

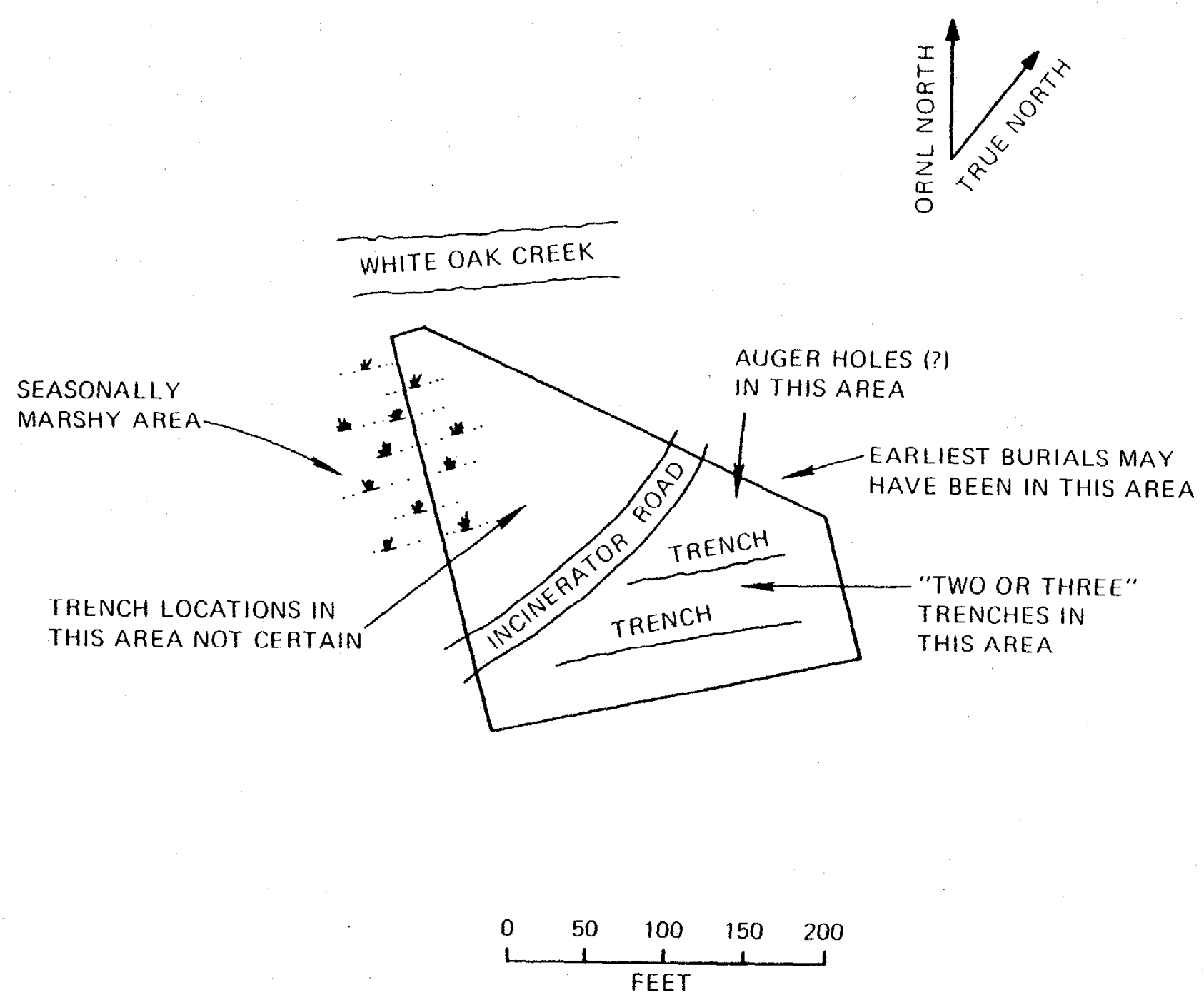

Fig. 4.14. Schematic diagram of SWSA-1 during operation. 

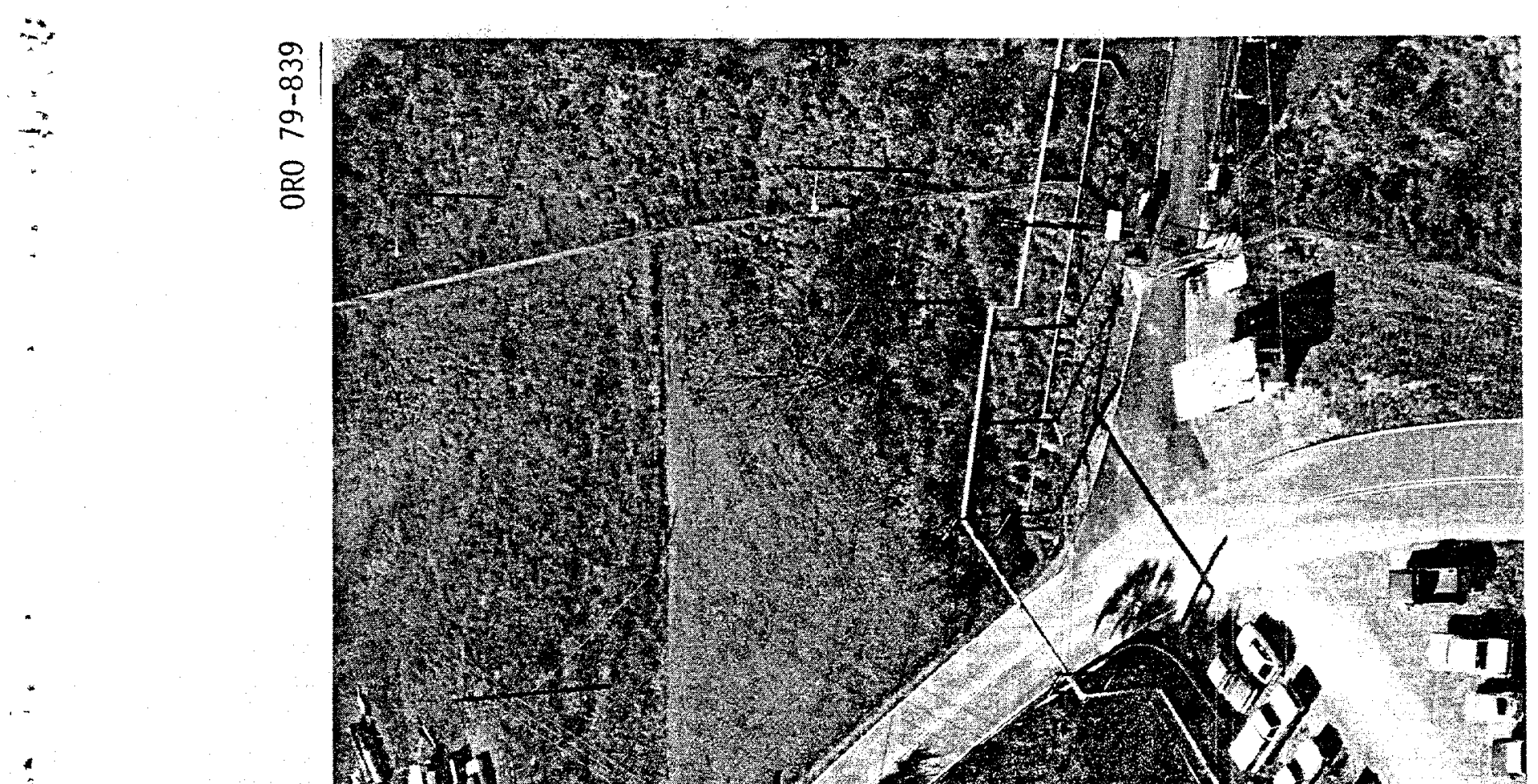

a, 11

$\because$

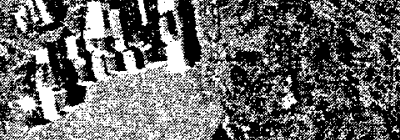

roments

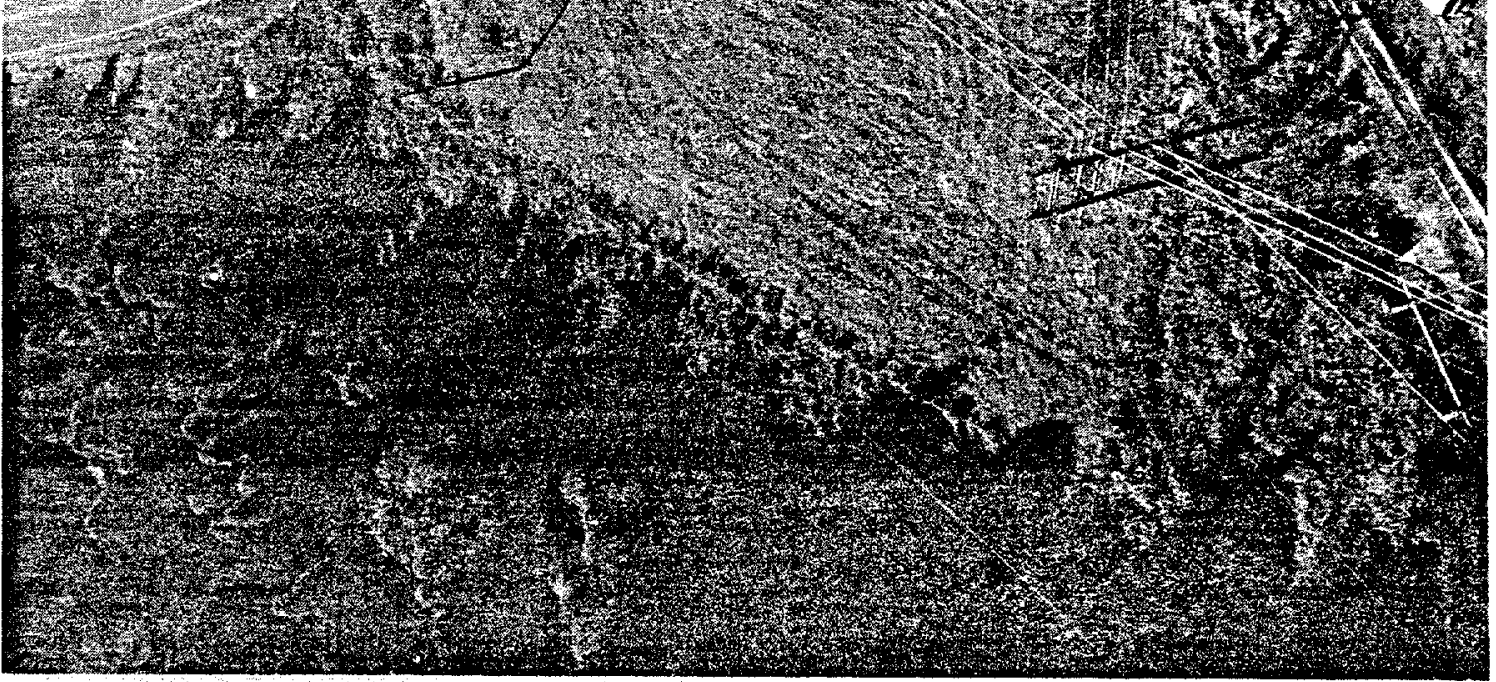

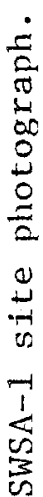

in

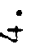

.

.0

I. 


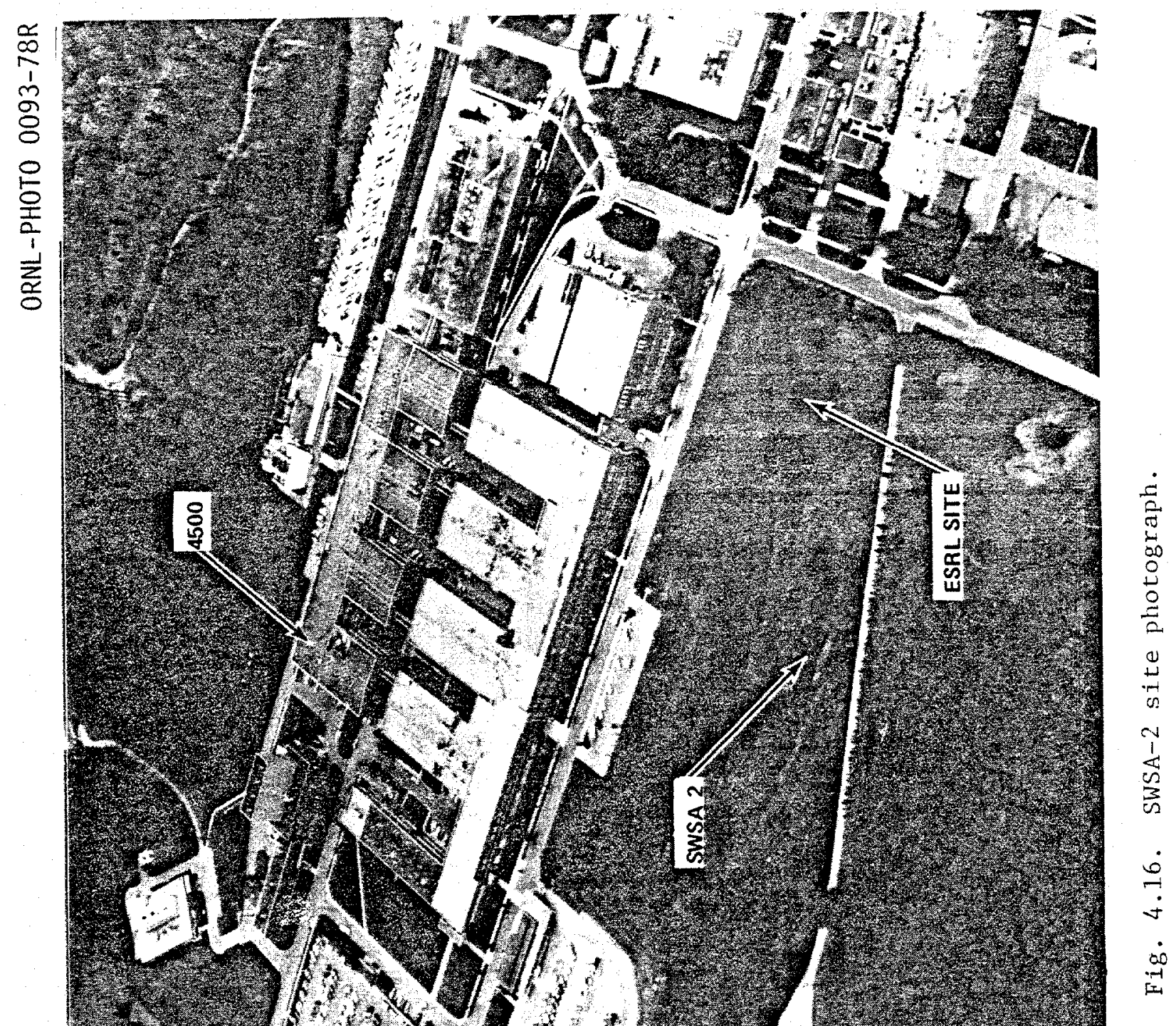




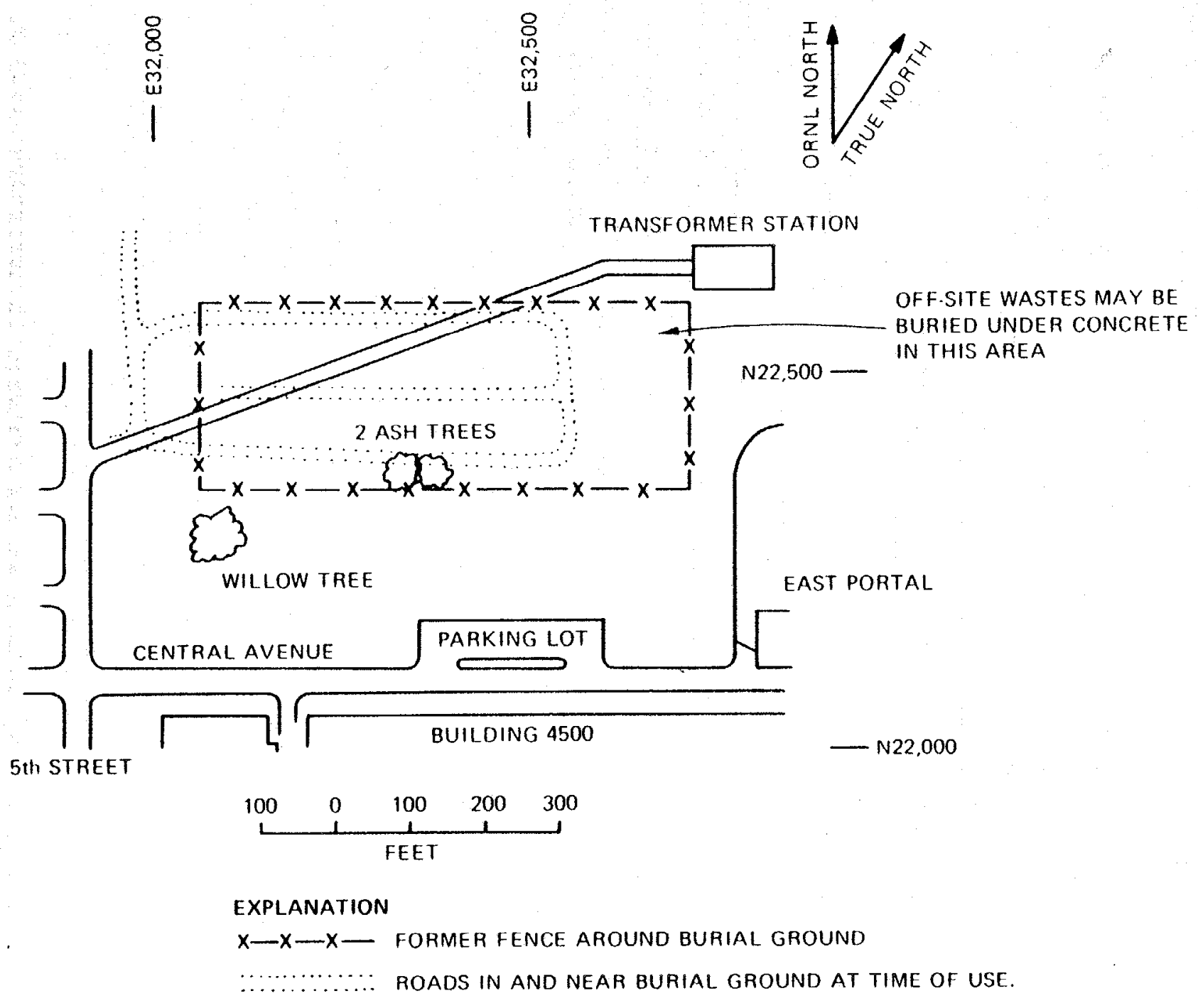

Fig. 4.17. Diagram of SWSA-2 site relative to present features. 
that the site initially had one trench cut in an east-west direction, probably between the roads indicated on Fig. 4.17, and then a second trench cut to the north of the first. 6 Solid waste contaminated by beta or gamma activity was placed in black iron drums and then buried in the trenches. Liquid waste contaminated with plutonium was placed in stainless steel drums and either buried in trenches or stored without burial in a "natural ravine" eroded in the site. 6 The northeast corner of the site is believed to have been used for the burial of alpha-contaminated material from off-site. This material was covered with a slab of concrete after burial.

Long-range land use planning soon indicated that the area was unacceptable as a burial ground and the site was closed. After closure, all the waste was reported to have been exhumed and reburied at a new burial site (SWSA-3). The stainless steel drums containing liquid plutoniun waste were removed intact, but the black iron drums containing the beta-gamna waste had deteriorated and required removal of the surrounding soil. The area was then bulldozed and seeded with grass. Surface water runoff from above the area has been diverted around the trenches to minimize erosion.

Conflicting reports have existed in regard to the removal of the buried waste from SWSA-2 with some accounts indicating that not all the waste was removed, in particular, larger equipment such as storage tanks and vehicles which had been disposed of at the site. Extensive core sampling has been completed in and around SWSA-2 since 1976 to determine the nature of the subsurface materials for a proposed Laboratory facility, the Energy Systems Research Laboratory (ESRL). 9 The proposed ESRL site includes the southwestern part of SWSA-2 and the area between SWSA-2 and Central Avenue (Fig. 4.16). A total of 25 cores were taken, ranging in depth from 1.2 to $2.7 \mathrm{~m} \mathrm{(4} \mathrm{to} 9 \mathrm{ft}$ ), and the soil samples were analyzed for gamma-, beta-, and alpha-emitting isotopes. Water taken from 13 of the core holes was analyzed to determine tritium, gross beta, and gross alpha levels. None of the samples analyzed were found to be significantly higher than background samples collected throughout 
eastern and central Tennessee. Results of these analyses indicate that there has been no significant migration of radionuclides from SWSA-2 and that probably most if not all of the contamination has been removed from the area. Figure 4.18 shows the sampling locations used in the above analysis.

\section{2 .4 SWSA-3}

SWSA-3 is located in a fenced area at the foot of Haw Ridge approximately $1.0 \mathrm{~km}$ ( 0.6 miles) west of the Laboratory complex. The site was opened in April 1946, and remained operational for approxinately five years. In recent years, after being closed for trench disposal, the site. was used for above ground storage of reuseable equipment. Figure 4.19 illustrates the location of the SWSA.

Trenches were cut parallel to each other across the width of the site as shown in Fig. 4.20. Alpha contaminated waste was placed in trenches and then covered with concrete whereas the beta-gama waste trenches were backfilled with native soil. Trenches in the area were generally $4.5 \mathrm{~m}$ (15 ft) deep or less. ${ }^{7}$ The site was expanded westward until hard rock was encountered which made excavation difficult, and the site was closed in 1951 after utilizing some $2.4 \times 10^{4} \mathrm{tn}^{2}$ (6 acres).

During 1978 and 1979 , a cleanup program was initiated to remove the above-ground stored material from SWSA-3. Laboratory personnel were notified to identify and tag any items which they wanted to save. All material not tagged was removed from the area. Stored items with detectable contamination levels were removed and buried in trenches in SWSA-6. Stored items with contamination levels undetectable by field survey instruments were buried in a landfill in SWSA-5. Radioactively contaminated items which were tagged for continued storage were renoved to an improved storage area near SWSA-4. After removal of above-ground stored items, the east section of SWSA-3 was covered with about $20 \mathrm{~cm}$ ( 8 in.) of dirt and sown with grass. A ditch was dug along part of the south fence line to divert runoff from across the surface of the area. All trees which had grown in the area were removed. Figure 4.21 shows SWSA-3 after completion of the clean-up program. 


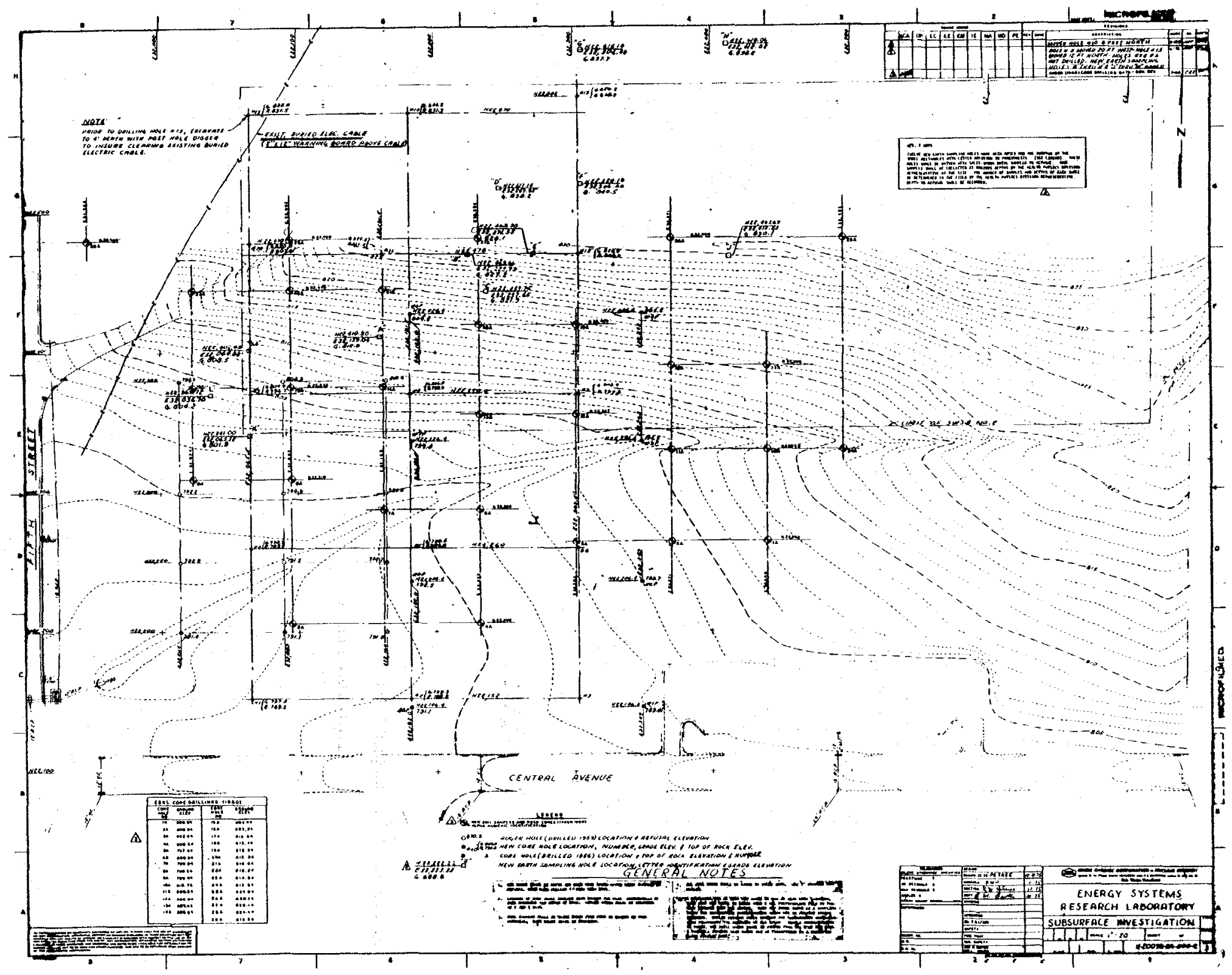

Fig. 4.18. Locations of core samples taken in area of proposed ESRL. 


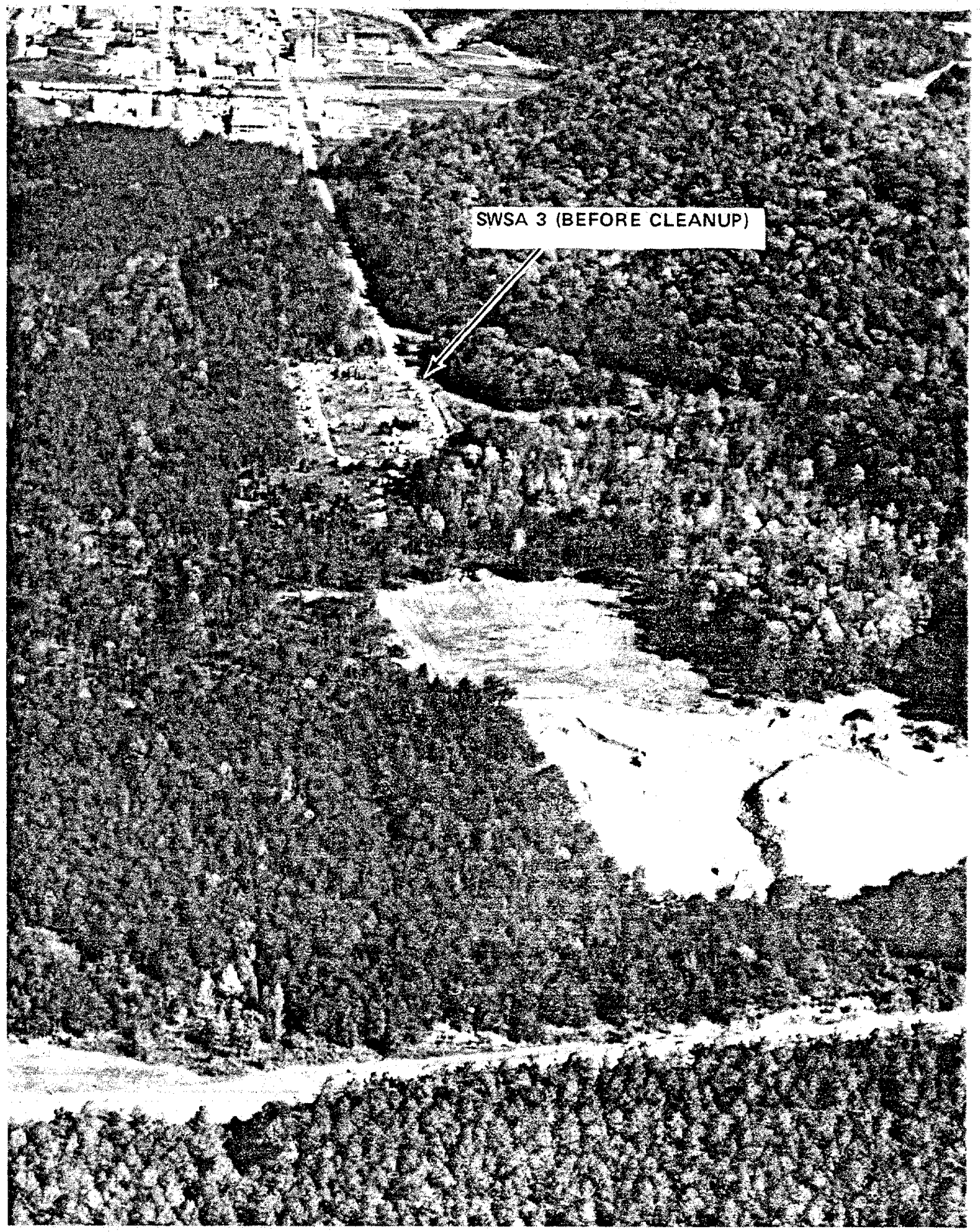

Fig. 4.19. SWSA-3 site photograph. 

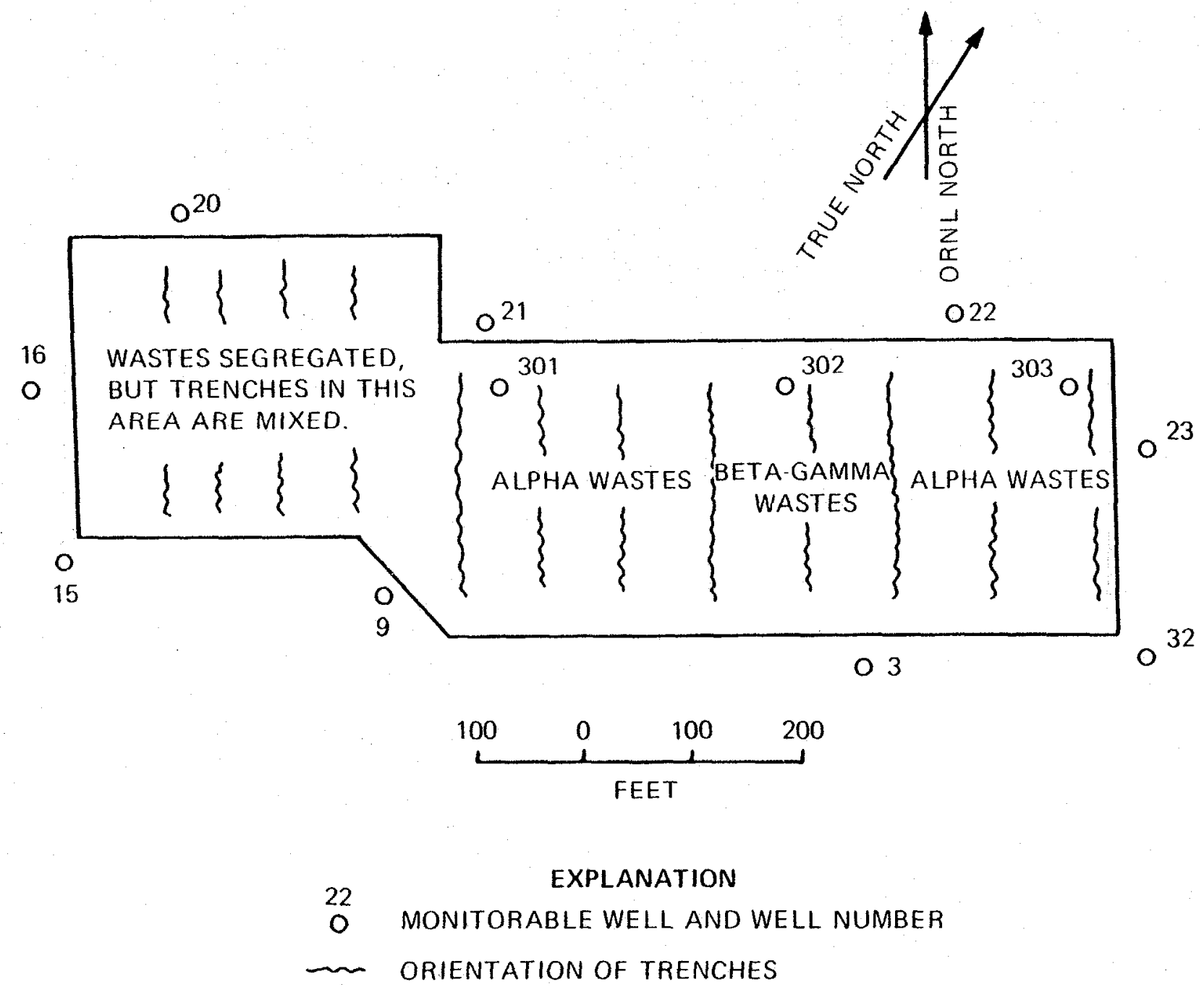

Fig. 4.20. Schematic diagram showing the orientation and general location of alpha and beta-gamma trenches in SWSA-3. 


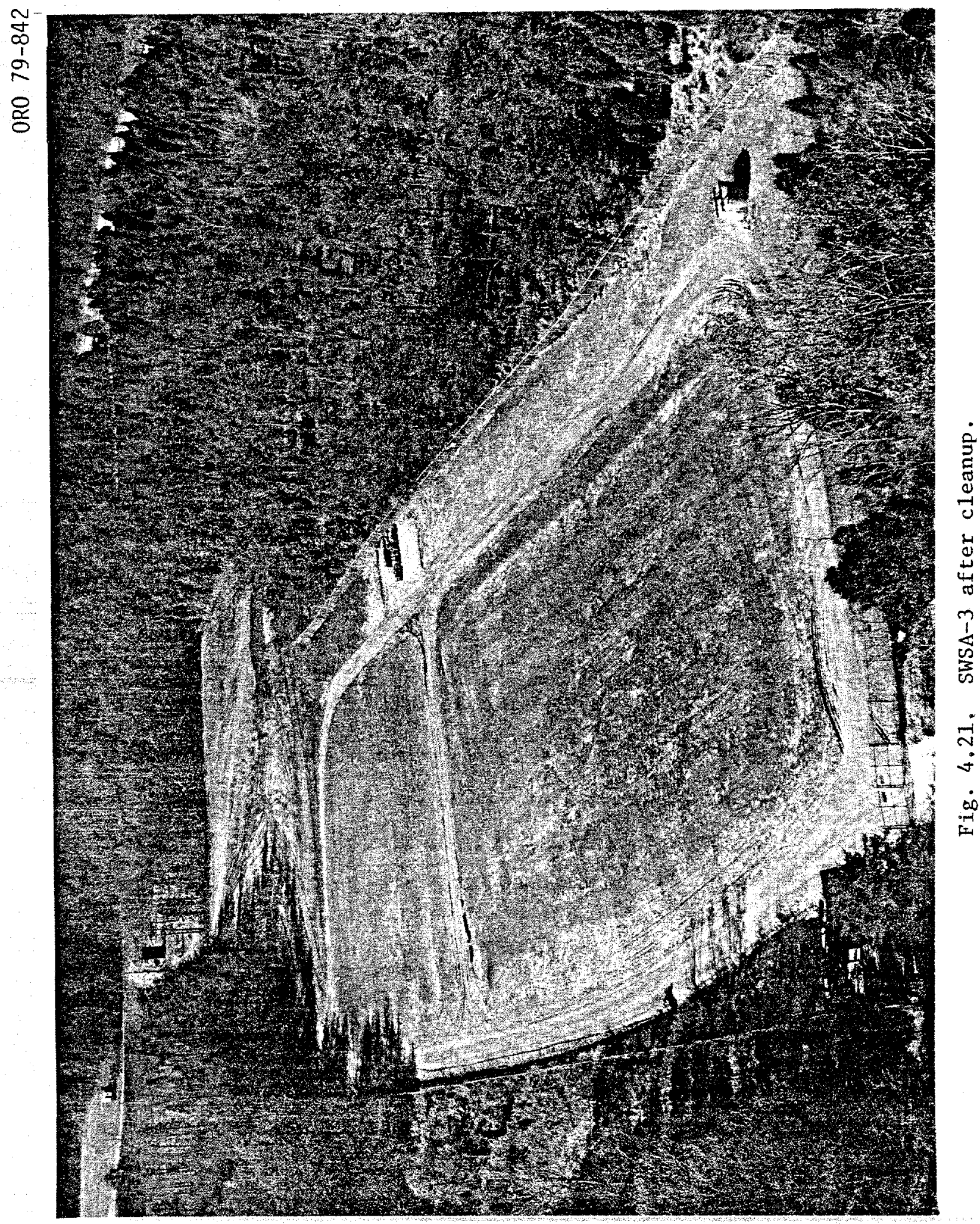




\subsubsection{SWSA-4}

Sufficient studies had been completed on radionuclide movement within burial areas by 1951 to indicate the potential of the Conasauga shale for absorption of radionuclides. SWSA-4 was sited in Melton Valley in areas underlain by Conasauga shale to take advantage of this property. The site selected is located within the White Oak Creek drainage basin approximately $0.8 \mathrm{~km}(0.5$ miles) southwest of the Laboratory complex. The SWSA is bounded on its western border by Lagoon Road, an ORNL access road. The site is currently fenced and grassed. Figure 4.22 is a recent aerial photograph of the area.

SWSA-4 was opened for routine burial in February 1951, and remained in operation for approximately 8.5 years encompassing a total area of $9.3 \times 10^{4} \mathrm{~m}^{2}(23$ acres $)$. The site was utilized at a rate of around 1.0 $x 10^{4} \mathrm{~m}^{2}$ (2.5 acres) per year. Development of the SWSA proceeded gradually from the low-lying northeast end to the higher southwest end. Trench orientation was variable and lacked any consistent relationship to the original site topography. A trench for burning noncontaminated material was also operated within the area. Much of the site, primarily in the northeastern portion, has been covered with rock and dirt from building excavations at ORNL. In some places as much as $6 \mathrm{~m}$ ( $20 \mathrm{ft}$ ) of this material overlies the original ground contour. 8

Trench burial was utilized in SWSA-4 for routine beta-gamma wastes. Trenches ranged from 15 to $120 \mathrm{~m}$ (50 to $400 \mathrm{ft}$ ) in length, 2.4 to $9 \mathrm{~m}$ (8 to $30 \mathrm{ft}$ ) in width, and 2.4 to $4.3 \mathrm{~m} \mathrm{(8} \mathrm{to} 14 \mathrm{ft}$ ) in depth. Burial was limfted to high elevations within the burial area during the drier wet periods, while the low topography was utilized during the drier summer months. Alpha-contaminated wastes were disposed of in trenches with the addition of an $0.5 \mathrm{~m}(1.5 \mathrm{ft}$ ) concrete slab poured over the trench. Higher-level wastes and some "special high-level" wastes were placed in auger holes 0.3 to $0.6 \mathrm{~m} \mathrm{(} 1$ to $2 \mathrm{ft}$ ) in diameter and approximately $4.6 \mathrm{~m}$ (15 ft) deep. 

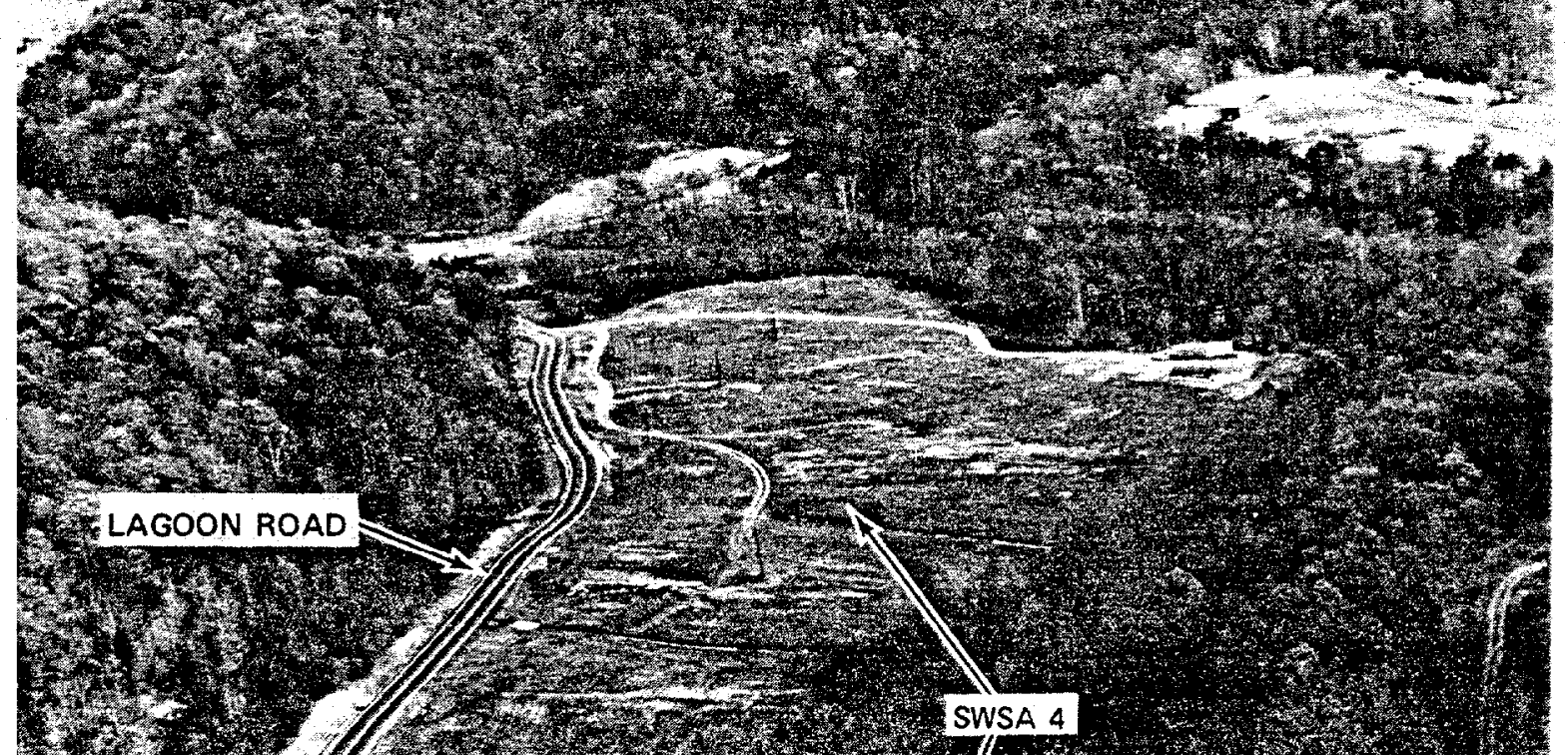

ROAD

3

36.

(3)

4.

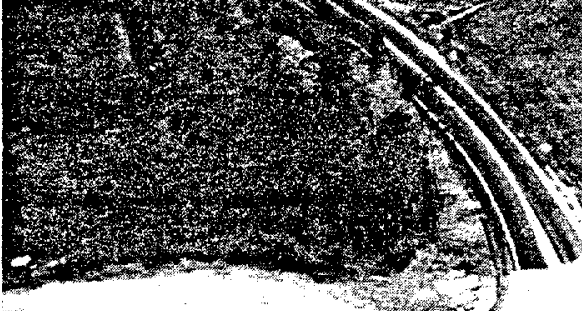

3.t.

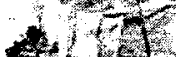

3.t.

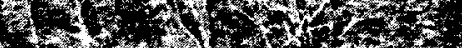

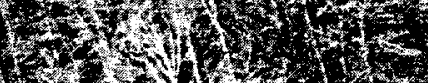

$+2 \times 14$ W

$x^{2}+x^{2}+2 x_{2}$

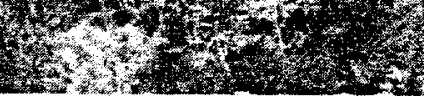

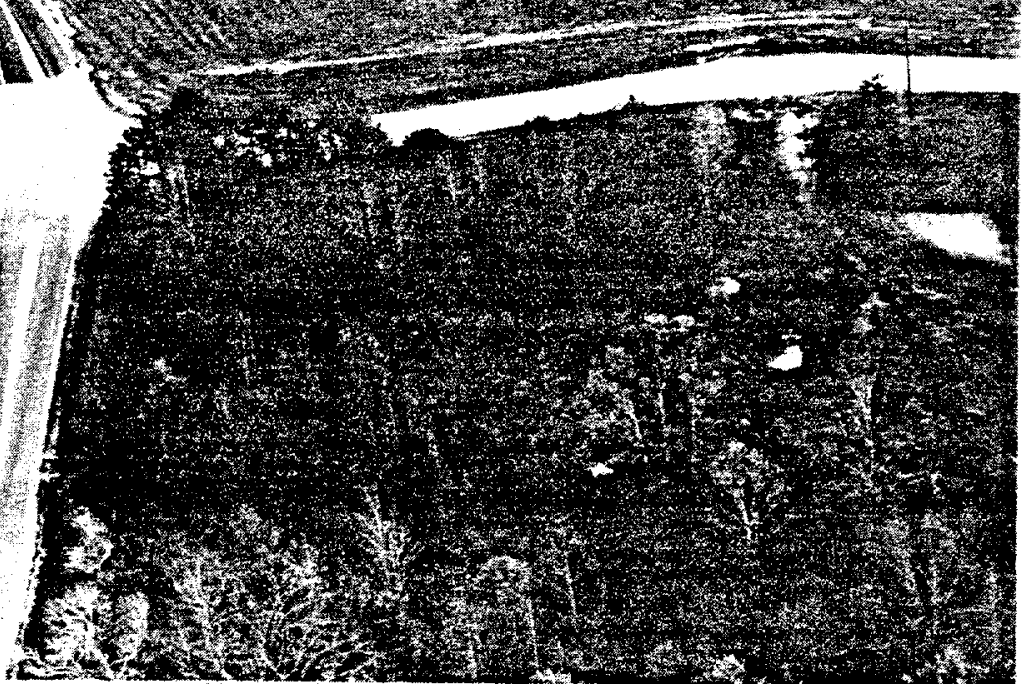

Fig. 4.22. SWSA-4 site photograph. 
Auger holes were also used for the temporary storage of materials contaminated by fission products of short half life. About 50 of these auger holes are located in the northern part of the SWSA along Lagoon Road. ${ }^{8}$. Figure 4.23 shows the SWSA-4 trench alignment, type of cover (shale or concrete), the high-level waste burlal areas, and the noncontaminated burning pit.

A wide variety of contaminated waste was buried in SWSA-4 in a wide variety of contalner types. The list includes materlals such as paper, glassware, scrap metal, dirt, filters, olls, powders, depleted uranium, aninal carcasses, and large pieces of equipment. In one case a small metal building was buried at the site. ${ }^{8}$ Records were maintained of the waste inventory of SWSA-4, but were destroyed in 1957 by fire. Records are available for 1957 and 1958 which may be representative of the immediately previous years. During 1957 approximately $7220 \mathrm{~m}^{3}\left(255,000 \mathrm{ft}^{3}\right)$ of waste was buried in SWSA-4 and during 1958 approximately $9510 \mathrm{~m}^{3}$ $\left(336,000 \mathrm{ft}^{3}\right)$ was buried. Approximately 50 percent of this waste was generated by ORNL with the remalnder being shipped in from off-site. Table 4.4 illustrates the diversified group of generators of the burled waste during 1957 and 1958. Little information exists to characterize the type, concentration, or quantity of radionuclides placed in SWSA-4 for any of its years of operation. The curie content description of off-site wastes was frequently incomplete and in many cases was specifled in "less than" quantities which may differ greatly from the actual quantity.

Although the existence of Conasauga shale was the determining factor in the site selection for SWSA-4, 1ittle consideration was given to other geologic and hydrologic parameters. Consequently, much of the waste in SWSA-4 is located in or very near the water table as 11lustrated by the shift to higher ground during the wet winter months. This factor has resulted in radionuclide transport within the burial area with the development of a number of "seeps" near the lower portion of the SWSA. Radionuclide movement into White oak Creek is relatively small, but these seeps are a major concern in SWSA operation and monitoring. 

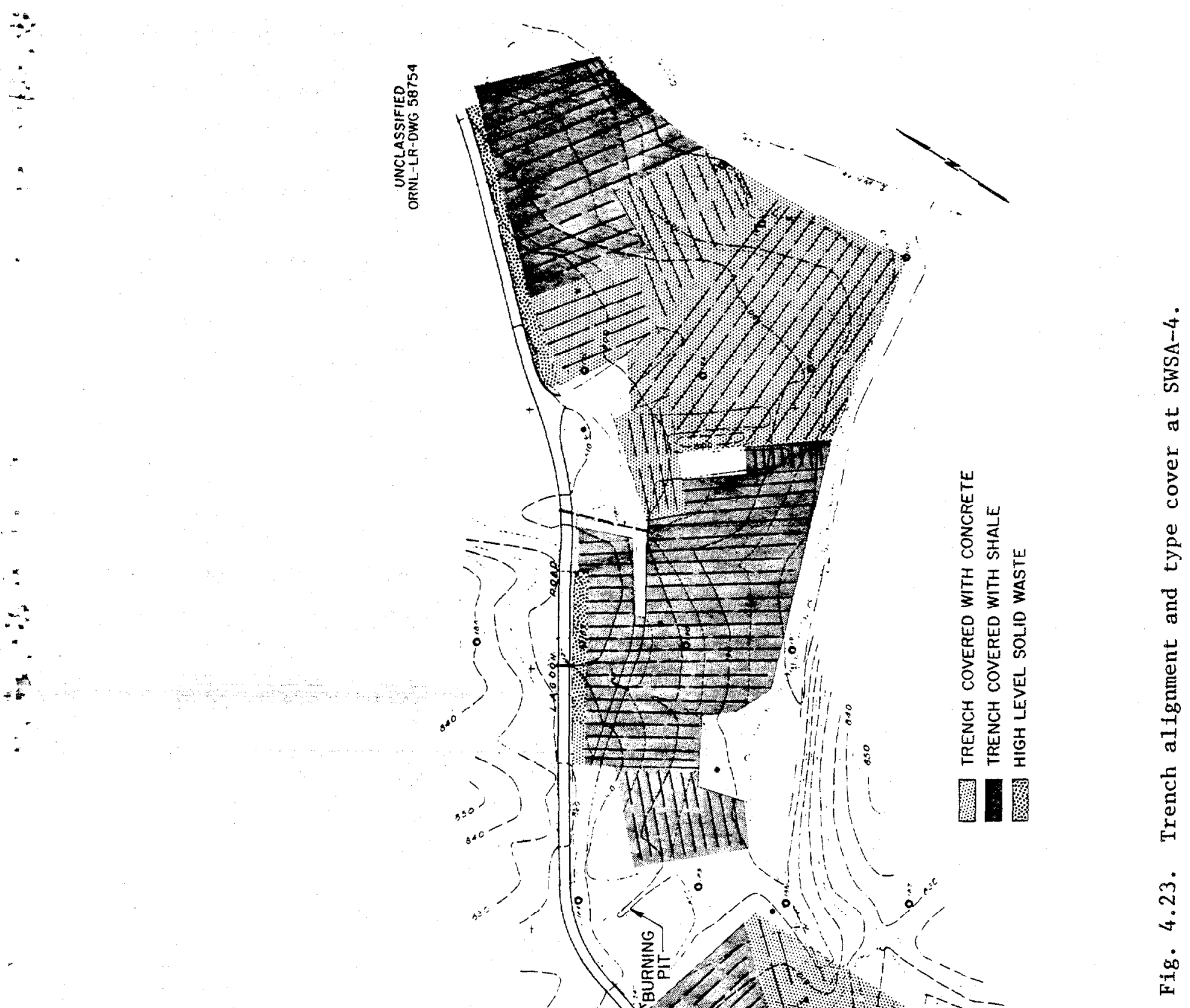
Table 4.4. Solid-waste burials for 1957 and 1958

\begin{tabular}{|c|c|c|c|c|c|c|}
\hline & \multicolumn{3}{|c|}{1957} & \multicolumn{3}{|c|}{1958} \\
\hline & \multicolumn{3}{|c|}{ Volume } & $\left(\mathrm{ft}^{3} \times 10^{3}\right)$ & \multicolumn{2}{|c|}{ Volume } \\
\hline ORNL & 142 & 4020 & 55.7 & 158 & 4470 & 47.0 \\
\hline $\mathrm{Y}-12$ & 10 & 280 & 3.9 & 15 & 420 & 4.4 \\
\hline $\begin{array}{l}\text { U. T. Agricultural } \\
\text { Experimental Station }\end{array}$ & 4 & 110 & 1.6 & 4 & 110 & 1.3 \\
\hline ORINS & 1 & 28 & 0.4 & 1 & 28 & 0.3 \\
\hline Oak Ridge Processing Co. & 6 & 170 & 2.3 & 16 & 450 & 4.8 \\
\hline Knoxville Iron Co. & 4 & 110 & 1.6 & 11 & 310 & 3.2 \\
\hline $\mathrm{k}-25$ & 4 & 110 & 1.6 & & & \\
\hline off-Site Shippers & & & & & & \\
\hline KAPL & 25 & 710 & 9.8 & 52 & 1470 & 15.5 \\
\hline ANL & 29 & 820 & 11.4 & 34 & 960 & 10.1 \\
\hline$G E$ & 7 & 200 & 2.7 & 19 & 540 & 5.6 \\
\hline Mound Laboratory & 14 & 400 & 5.5 & 11 & 310 & 3.3 \\
\hline Radiological Service Co & . & 110 & 1.6 & 4 & 110 & 1.2 \\
\hline BMI & & & & 4 & 110 & 1.2 \\
\hline Others & 5 & 140 & 1.9 & 7 & 200 & 2.1 \\
\hline TOTALS & $255^{a}$ & $7208^{a}$ & 100.0 & $336^{a}$ & $9488^{a}$ & 100.0 \\
\hline
\end{tabular}

asome discrepancies exist with respect to these numbers. The numbers currently considered to be accurate are given in Table 4.7. This table is presented simply to show the diversity of generators. 


\section{2 .6 SWSA -5}

SWSA-5 was opened in 1959 as SWSA-4 neared full capacity. The selection of the site for SWSA-5 was based on experience gained as a result of previous burial operations as well as studies which were completed on radionuclide transport within soil. Criteria were established for selection of the SWSA-5 site including such considerations as depth to groundwater, ease of operation, flood potential, soil erosion by surface runoff, easy excavation, short hauling distance, restricted access roads, and underlying geology. The site selected is located on a hillside east of White Dak Creek, between SWSA-4 and Melton Branch. SWSA-5 is composed of two distinct geographical areas providing different solid waste storage functions. These areas will be referred to as SWSA-5/north and SWSA-5/south. SWSA-5/south is used for disposal of routine buried waste; whereas, SWSA-5/north has been used for retrievable storage of transuranic contaminated waste.

SWSA-5 (north and south) is a fenced area of approximately $3.2 \mathrm{x}$ $10^{5} \mathrm{~m}^{2}$ (80 acres) of which only approximately $2.0 \times 10^{5} \mathrm{~m}^{2}$ (50 acres) has actually been used for waste disposal. The majority of this area is contained in SWSA-5/south. SWSA-5/south is a moderately sloping hillside with a grass cover (Fig. 4.24). The area is fenced and contains several unpaved access roads. Portions of the area are topographically or hydrologically unsuitable for trench disposal and thus have not been used for burial of waste. The original ORNL Hydrofracture Facility, utilized for many years for permanent disposal of ORNL generated 11quid waste, but now deactivated, is located at the southwestern corner of SWSA-5/south.

Waste disposal in SWSA-5/south was accomplished in similar manner to the previous storage areas. Beta-gamma contaminated waste was disposed of by normal trench burial. Trenches in the area vary considerably in size from approximately 12 to $150 \mathrm{~m}$ ( 40 to $500 \mathrm{ft}$ ) in length. The trenches were located at right angles to the strike of the shale to prevent collapse of the trench walls and thus, most trenches are located 


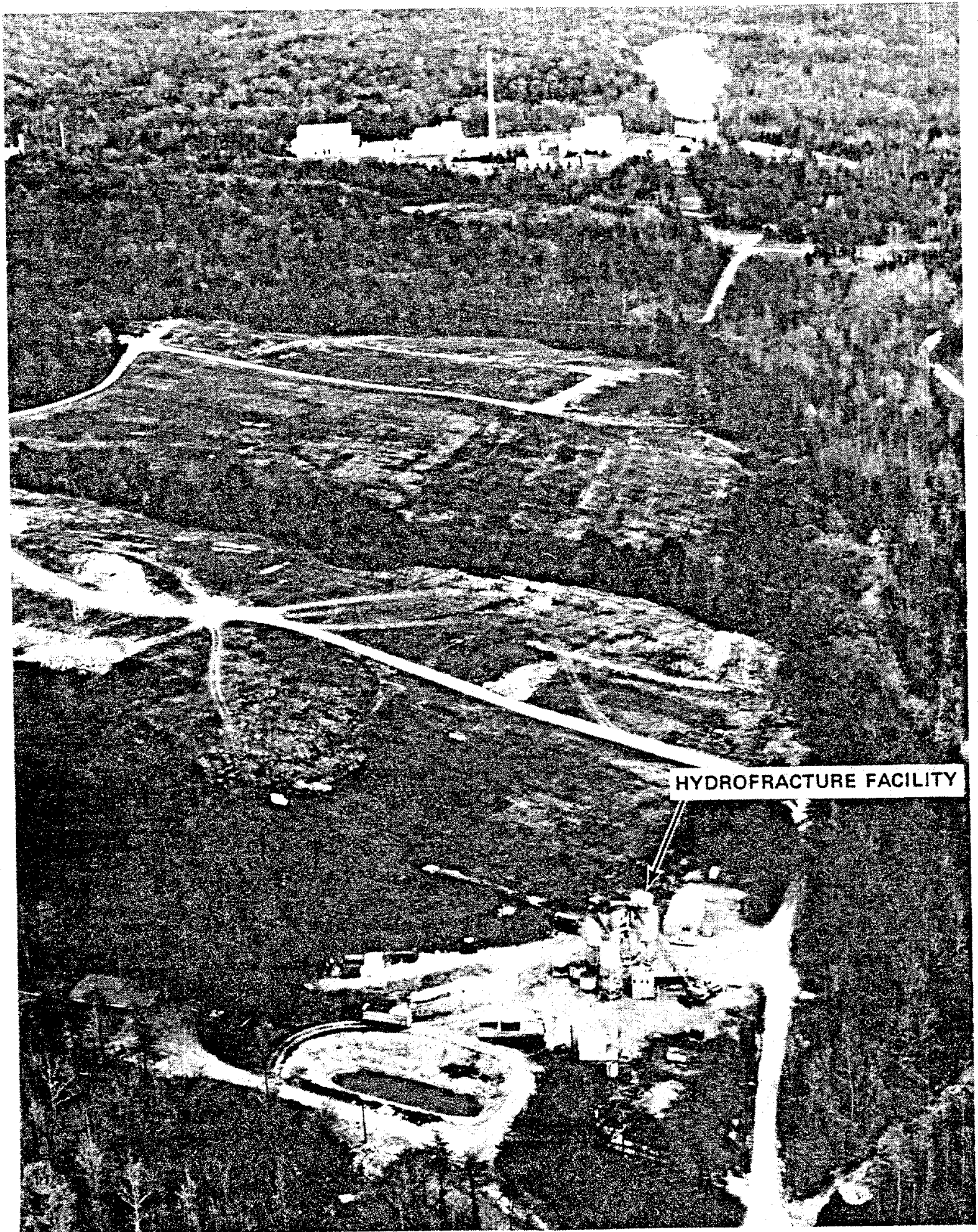

Fig. 4.24. SWSA-5 (south - nonretrievable) site photograph. 
parallel to the slope. Figure 4.25 illustrates the location and alignment of the trenches in SWSA-5/south. The records for the "undefined area" were destroyed in the fire which destroyed the SWSA-4 records. This "undefined area" was used primarily for disposal of segregated alpha contaminated waste which was trench buried and then covered with a slab of concrete. Auger holes were utilized for disposal of higher level waste and fissile waste in the areas designated on Fig. 4.25. SWSA-5/north has been used almost exclusively for the retrievable storage of transuranic waste. Figure 4.26 is an aerial photograph showing the numerous retrievable facilities in SWSA-5/north. Figure 4.27 also show these facilities along with the locations of trenches where waste has been retrievably buried.

TRU waste is stored in SWSA-5/north in three basic modes. Lowlevel TRU waste are placed in stainless steel drums which are held temporarily in a staging facility, Building 7823 , before being placed in partially underground storage facilities, Buildings 7826 and 7834 . Hot cell waste requiring shielding before disposal is placed in concrete casks which were previously buried in the trenches shown in Fig. 4.26. Currently, these concrete casks are being placed in the concrete storage facility, Building 7855. Waste with a high-level beta-gamma background is sealed in stainless steel containers and placed in stainless steel lined auger holes in Buildings 7827 and 7829 .

Also located in SWSA-5/north is Building 7824, which is primarily a storage building for miscellaneous equipment and also currently houses an experinental waste assay system. Some transuranic waste, which due to physical size or composition cannot be stored in the manner described above, has been disposed of by normal trench burial in the hillside just east of Building 7823 and across the access road from Buildings 7824 and 7826. SWSA-5/north is surrounded by a second security fence inside the primary SWSA-5 fence to further restrict access to the area. Outside the interior fence, near the main SWSA-5 entrance gate (Fig. 4.26) is located Builing 7331, the solid Waste Compactor Facility. This facility is used for volume reduction and packaging of low-level, nontransuranic and nonfissile, compactible wastes. 


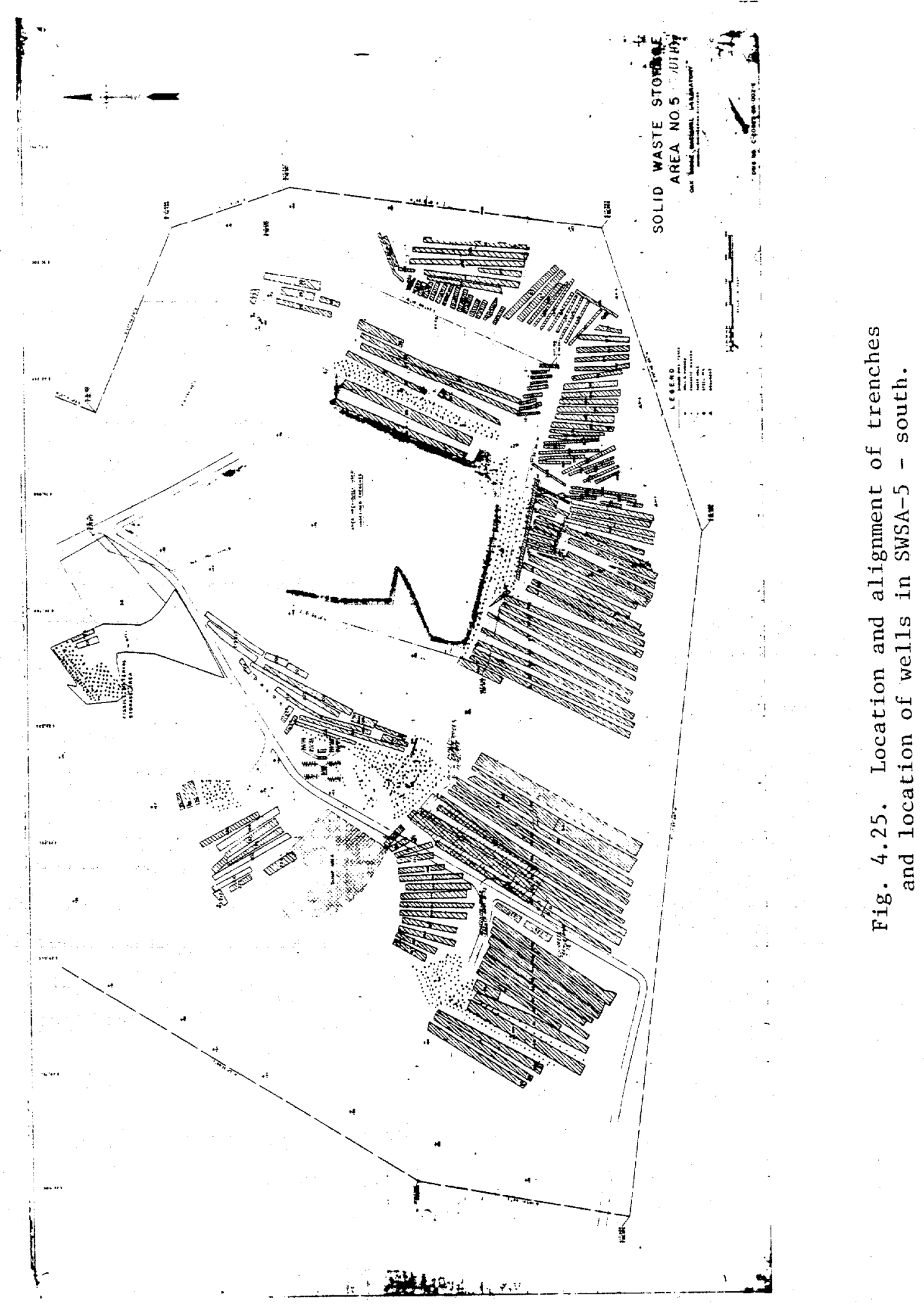




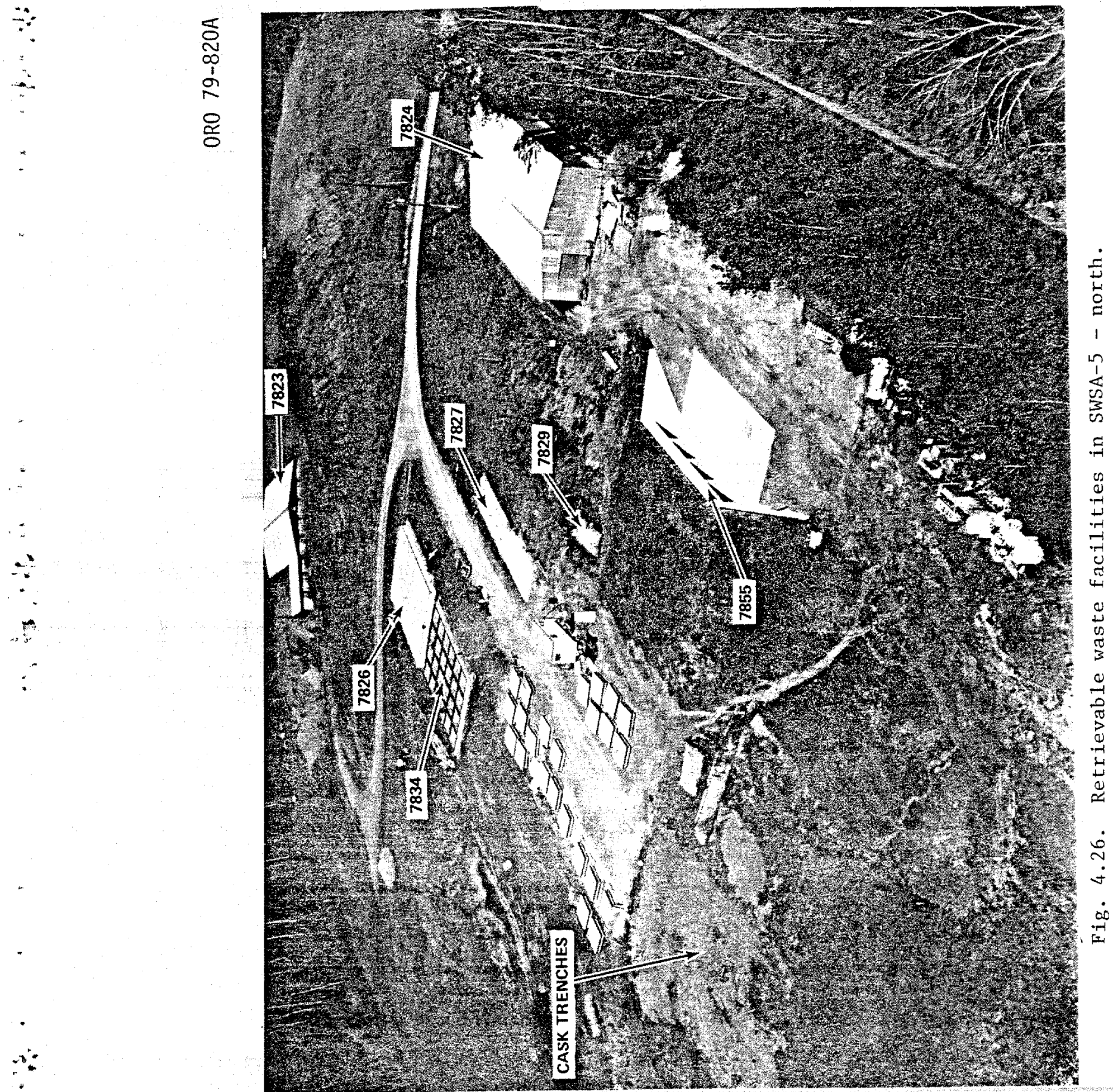




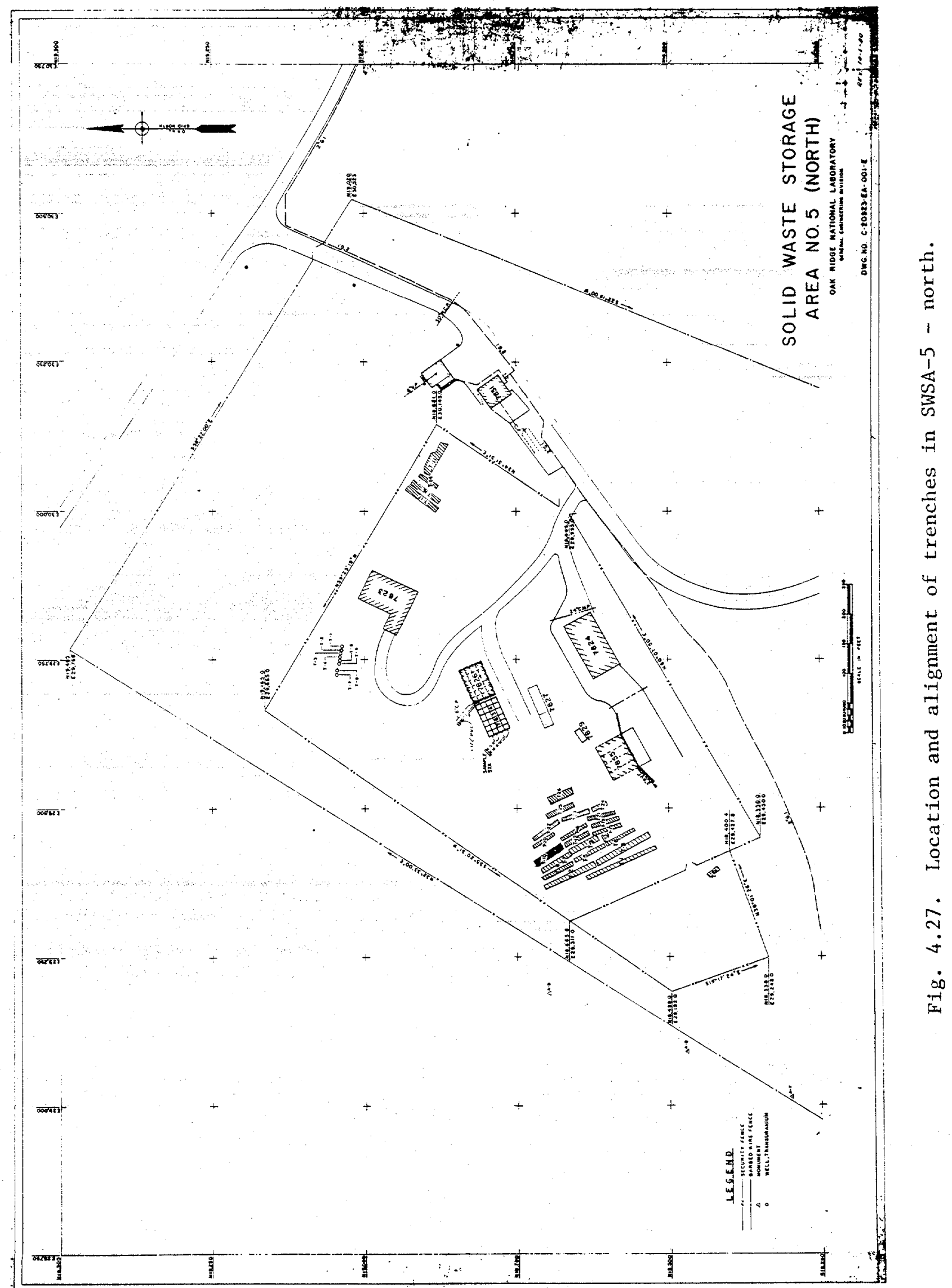


SWSA-5/south is currently clased for routine trench burial (1973) but SWSA-5/north continues to be used for storage of retrievable waste. Waste composition in SWSA-5/south is characteristic of the heterogeneous mixture described for the previous storage areas. Waste burials in SWSA-5 have varied from 0.7 to $1.5 \mathrm{~m}^{3} / \mathrm{m}^{2}(100,000$ to 220,000 cubic feet per acre) depending on terrain and water table depth.

\section{2 .7 SWSA-6}

SWSA-6 is the site currently used for routine nontransuranic waste burial. The site, opened in 1969, consists of a total area of $2.7 \mathrm{x}$ $10^{5} \mathrm{ta}^{2}$ (68 acres); however, only approximately $5.9 \times 10^{4} \mathrm{~m}^{2}$ (14.5 acres) of that area is useable due to the rough terrain. The site is located just northwest of White Oak Lake near White Oak Dam and Tennessee Highway 95. The area is generally sloping with wooded as weIl as cleared and grassed areas. The site is fenced and numerous unimproved access roads exist throughout the area. Since SWSA-6 is currently in use, open trenches and freshly filled trenches will be found in the area. Figure 4.28 is an aerial photograph of the SWSA- 6 site and Fig. 4.29 illustrates the topography and water table elevations of the site as well as location and alignment of existing trenches.

Selection of the site for SWSA- 6 was based on essentially the same criteria as was used in selecting the SWSA-5 site. The site is underlain by Conasauga shale and has similar hydrology to SWSA-5. Trenches are excavated as long as topographically convenient, but most are limited to approximately $15 \mathrm{~m}(50 \mathrm{ft})$. Auger holes are utilized in designated areas of the site for disposal of fissile waste and high level waste (Fig. 4.28). Special trenches have been designated in SwSA-6 for the disposal of biological waste and also for baled compactible waste. 
ORNL-PHOTO 0015-78R

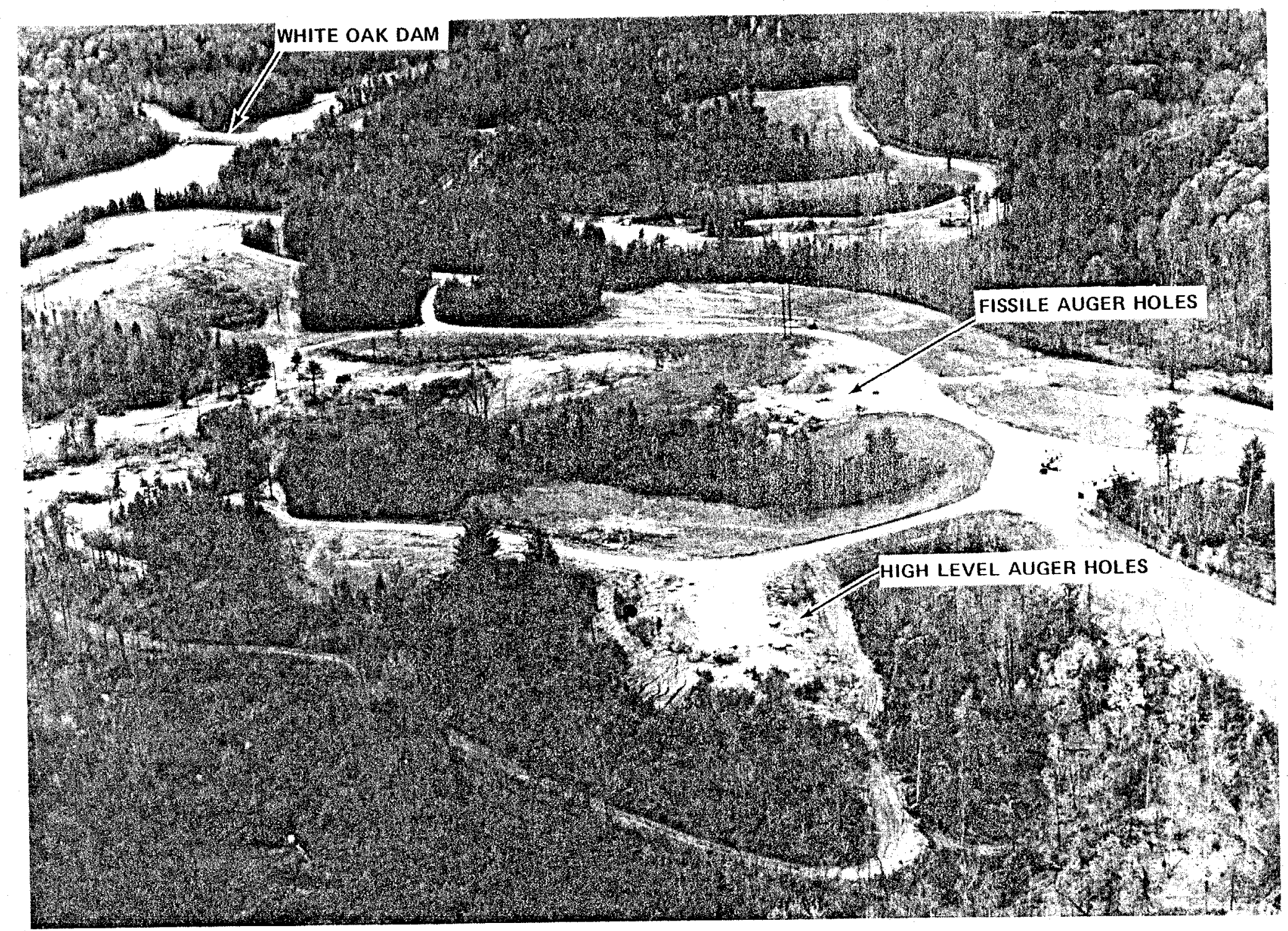

Fig. 4.28. SWSA-6 site photograph.

$\therefore \quad 3, x, y$

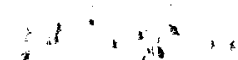

$\cdots \quad y^{2} a^{3}$ 

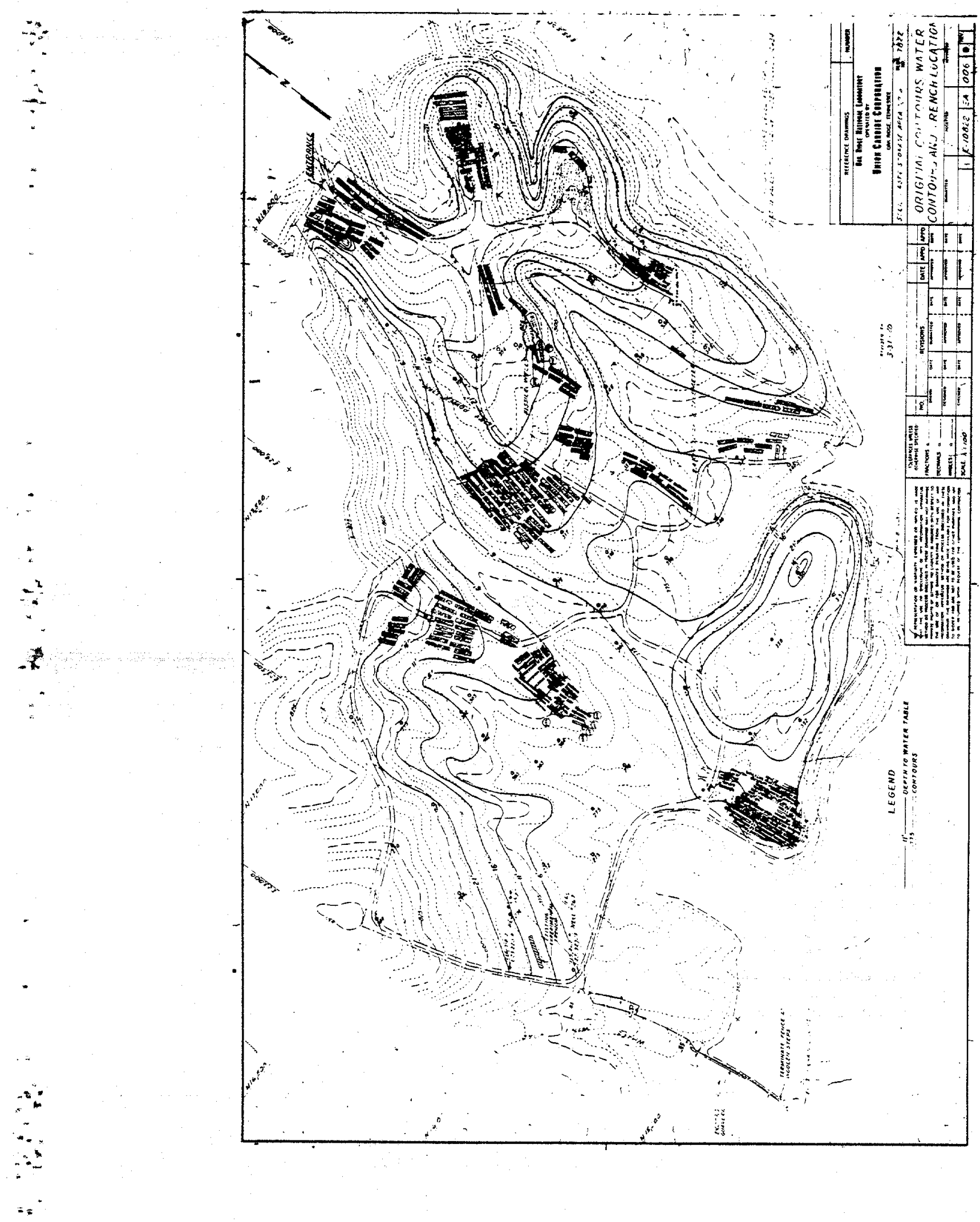

Dี 


\subsection{GENERAL SOLID WASTE DISPOSAL}

\subsubsection{Introduction}

The majority of solid radioactive waste disposed of at Oak Ridge National Laboratory is disposed of by one of two methods: trench burial or unlined auger holes. Trench burial is utilized for practically all low-level, nontransuranic, and nonfissile waste. Auger holes are used for waste containing fissile nontransuranic isotopes or waste exhibiting a high beta-gamma background, or both. Transuranic waste has also been disposed of in the past by trench burial normally accompanied by a layer of concrete over the top of the trench. Current practice does not allow tranch burial of transuranic waste except in very special cases. Instead, they are placed in special retrievable facilities to be discussed in Section 4.4 .

Trench burial was initlated at ORNL in accordance with standard nonradioactive landfill operation with little apparent consideration given to the design or layout of the trench. Investigations soon revealed that special procedures and precautions were necessary in trench burial of radioactively contaminated waste. Current practice utilized in SWSA-5 and SWSA-6 follows set procedures in the excavation, filling, and subsequent monitoring of trenches. A11 subsequent discussions regarding trench burial are based on current practice and procedure which may not accurately describe some of the earlier solid waste burials. The implication of this will be discussed in the subsequent sections on SWSA safety.

Auger holes are basically a specialized form of trench burial utilized to allow greater control of radiation exposures during disposal and to limit excessive quantities of fissionable material from accumulating in a given area. As with trench burial, detailed practices and procedures have been developed through numerous years of experience. 


\subsubsection{Trench Burial}

Trench development is dependent, to a large extent, on the specific topography, geology, and hydrology of the burial site. Trenches are constructed and maintained, using good engineering judgment and practice, in a manner which, to the extent possible, isolates the wastes and their radionuclide content from surface and ground water infiltration, and consequently, prevents any significant movement of the radionuclides. Figure 4.30 illustrates a typical trench layout.

Trenches are nominally $15 \mathrm{~m}$ (50 ft) long and $3 \mathrm{~m}(10 \mathrm{ft}$ ) wide depending on specific site topography. Depth is nominally 3 to $4.25 \mathrm{~m}$ (10 to $14 \mathrm{ft}$ ) with the depth of a specific trench being determined by the depth of the water table. Depth of all trenches is limited to at least $0.6 \mathrm{~m}(2 \mathrm{ft})$ above the known high water table as defined by the best currently available hydrologic profiles. If due to an unknown variance in the water table, a trench excavation is found to fall below the water table, the trench is backfilled prior to use with Conasauga shale to a depth at least $0.6 \mathrm{~m}$ ( $2 \mathrm{ft}$ ) above the observed high water table. Spacing between adjacent trenches in a storage area is limited to a mininum of $5 \mathrm{ft}$. Trenches are excavated with a slight slope toward one end and surface water drainage is controlled by appropriate ditching around trenches to meet prevailing surface drainage requirements.

The monitoring pipe in the trench of Fig. 4.30 illustrates a now abandoned practice of installing a monitoring well in each trench prior to addition of the waste. The pipe served as a trench marker and also as a sampling well. Monitoring wells continue to be used but are not installed until after the trench is filled as described in the following paragraphs.

When a trench has been properly excavated as illustrated in Fig. 4.31, the trench is ready to be filled. Filling of the trench occurs over a period of time with appropriate markers and barricades identifying the open trench. Waste is deposited in the trench in various 


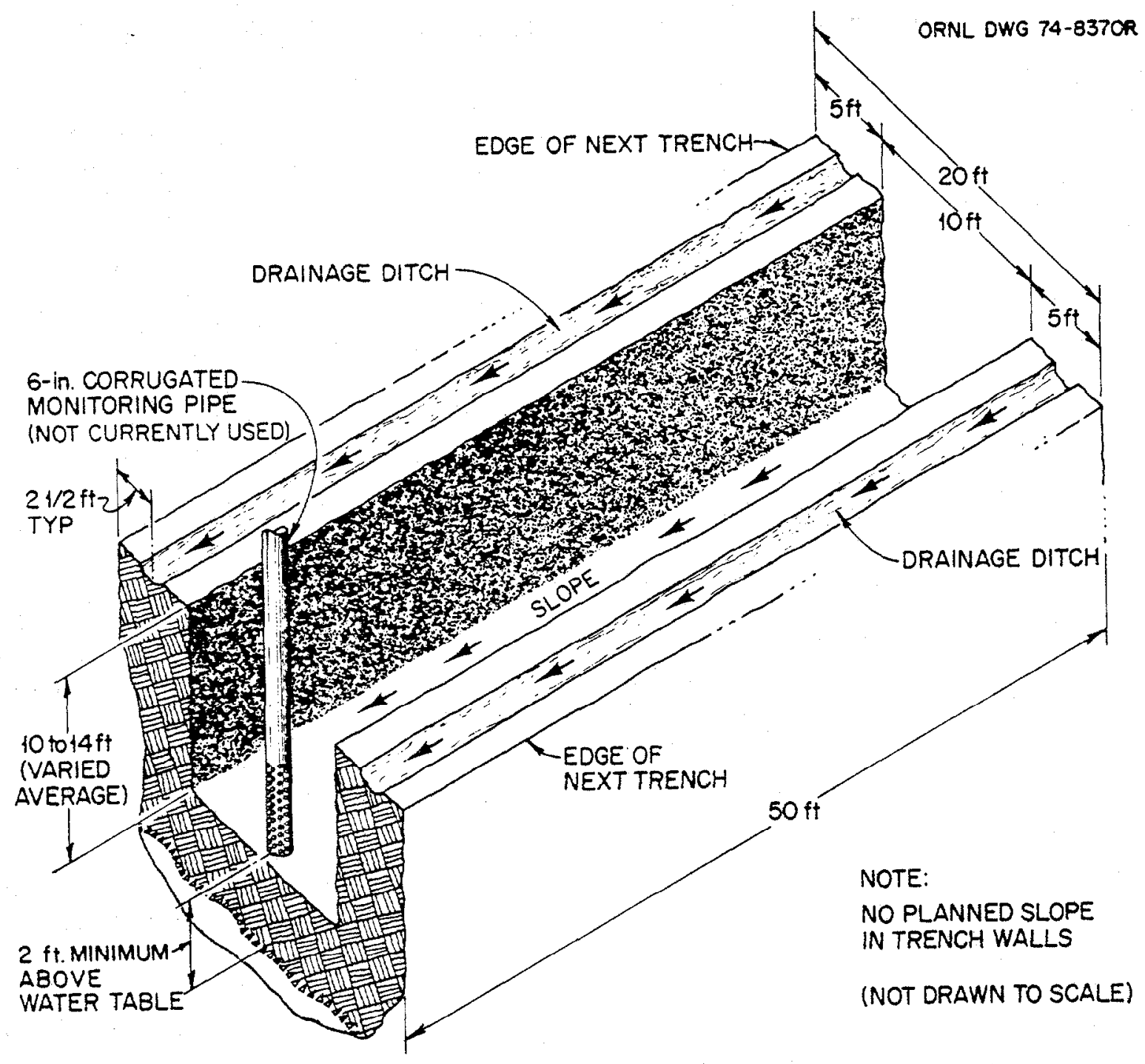

Fig. 4.30. Typical disposal trench layout. 

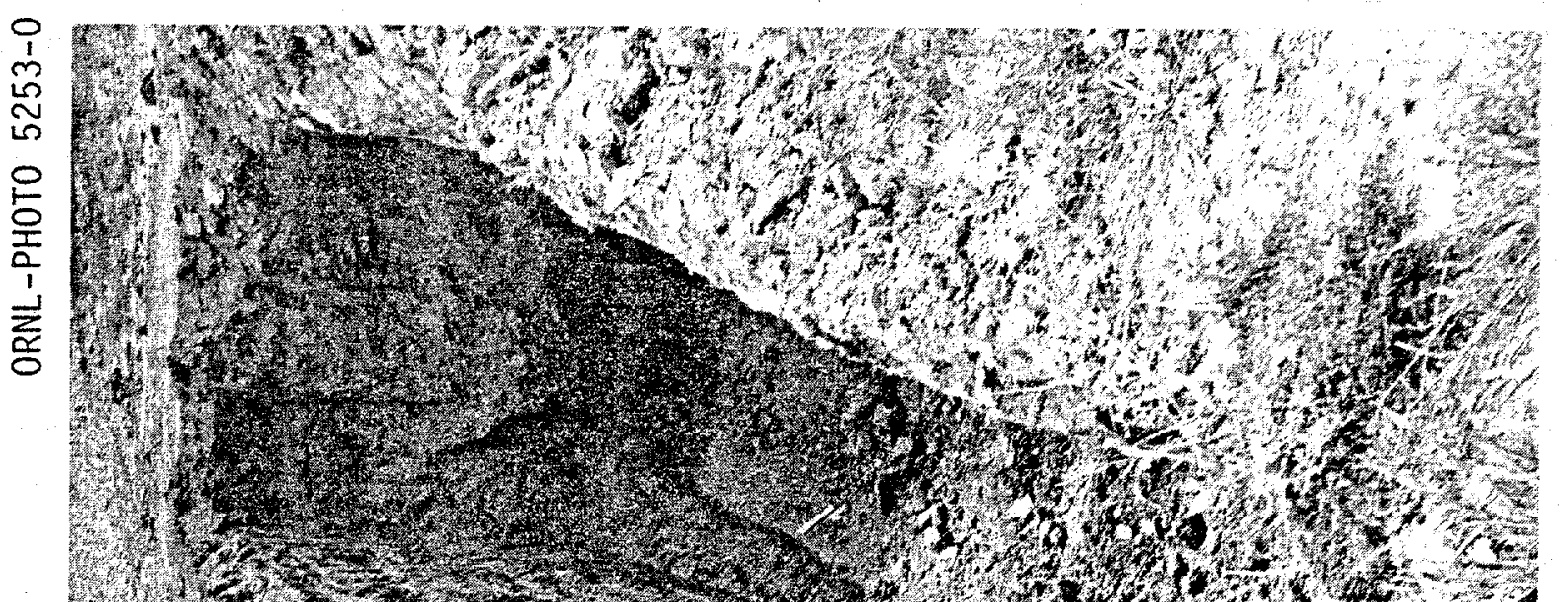

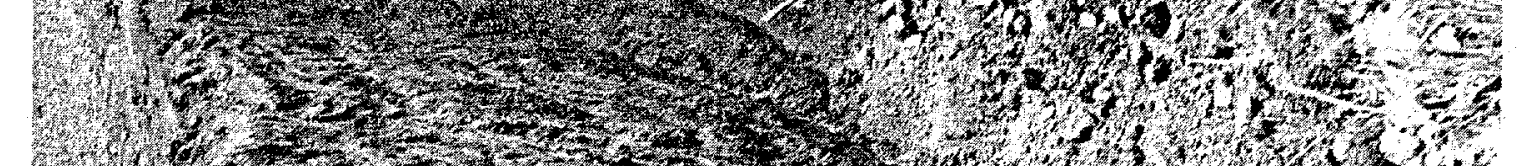
m,

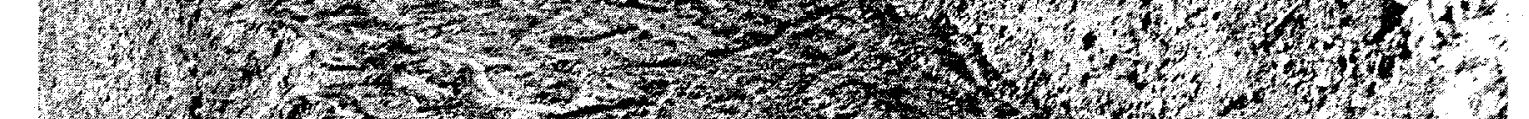
mor 1.7. 1.7. W.

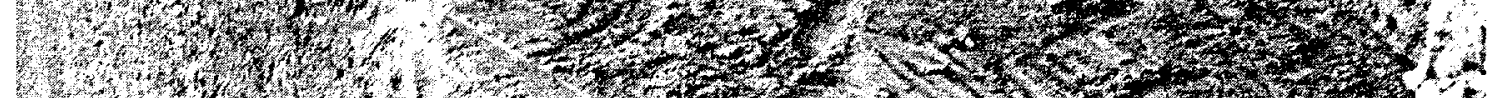

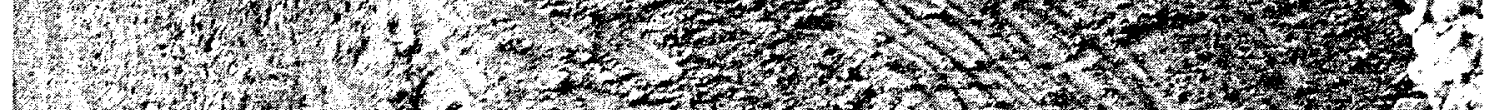

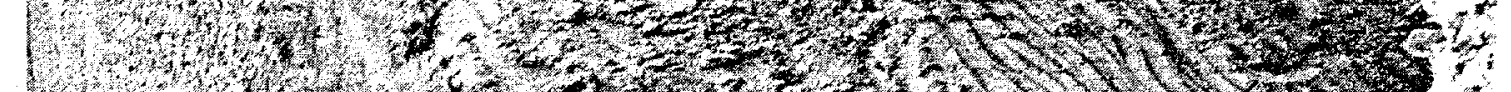

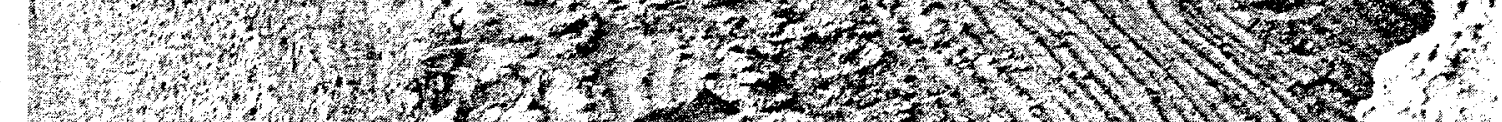
(1)

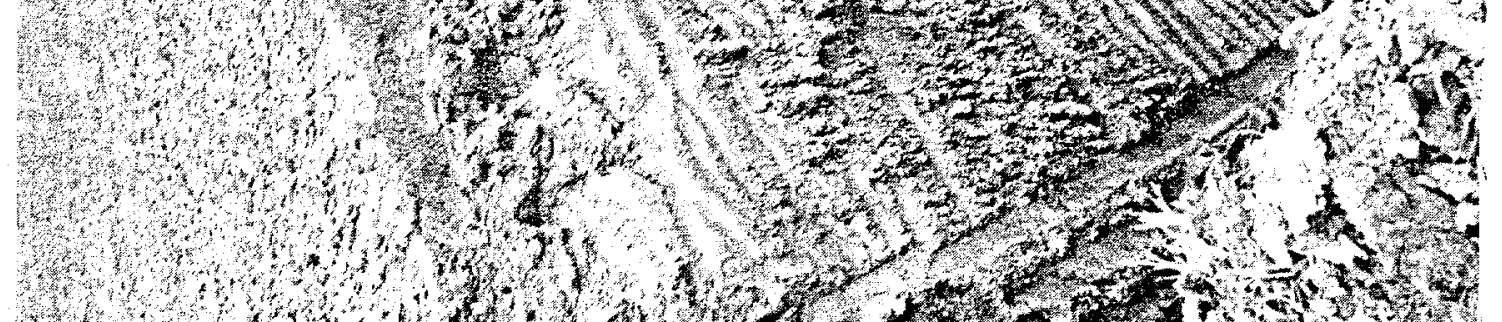

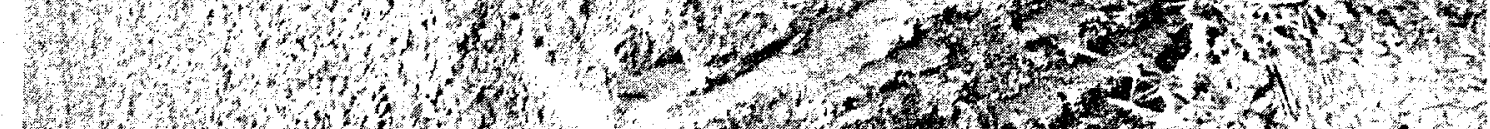

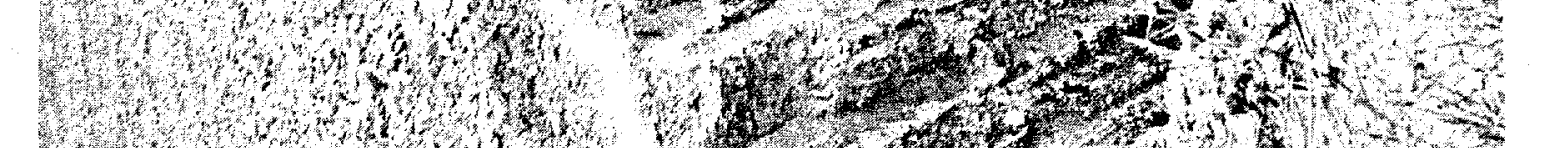

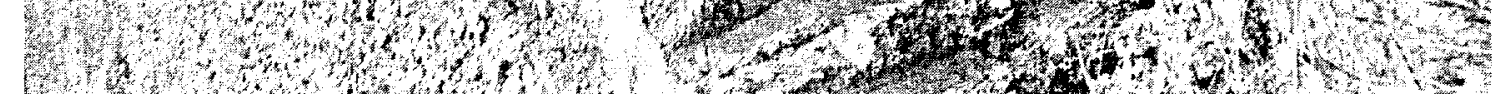
W.

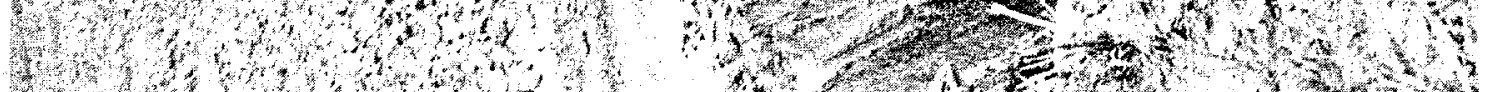
What, 
ways primarily by dumping of radwaste dumpsters by special trucks (Fig. 4.32), placement of individual packages, or as bulk waste in truck load 1ots. These operations comply with all procedures and requirements of the Health Physics Procedure Manual and are routinely monitored by Health Physics personnel, as necessary.

Waste is deposited in the trench to a level which allows not less than 3 ft of earth cover over the disposed material (Fig. 4.33). At this point, the trench is backfilled with native soil and packed by running heavy equipment over the area. Once the trench is closed, the area is grassed, mowed, and maintained free of trees. Periodically (approximately annually), trench areas that have been recently filled with waste are sealed with a bentonite clay-Conasauga shale cover to reduce water infiltration. The seal is at least $10 \mathrm{~cm}$ ( $4 \mathrm{in}$ ) thick and contains not less than $12 \%$ by volume granular bentonite clay. The mixture is sprayed with water to obtain a $20 \%$ moisture content and then covered with not less than 2 ft of shale/dirt before seeding.

After the bentonite clay/Conasauga shale seal has been installed over a group of trenches and the surface has stabilized, the corners of each trench are identified by civil engineering survey. Approximately on the centerline and $4 \mathrm{ft}$ frow the lower end of each trench, an auger hole is made to the bottom of each trench. A 4 in. diam plastic pipe slotted in the lower $3 \mathrm{ft}$ is inserted in the auger hole. The space in the auger hole surrounding the pipe is filled with gravel to within 3 ft of the surface; and then with a bentonite-shale mixture to within about 8 in. of the surface to seal around the pipe. A concrete collar (approximately $30 \mathrm{in.} \mathrm{diam)} \mathrm{is} \mathrm{then} \mathrm{installed} \mathrm{around} \mathrm{the} \mathrm{top} \mathrm{of} \mathrm{the}$ sampling well. The collar is marked with the well number, and the well is closed with a loose cover. Figure 4.34 shows a completed monitoring well with collar and identification. 


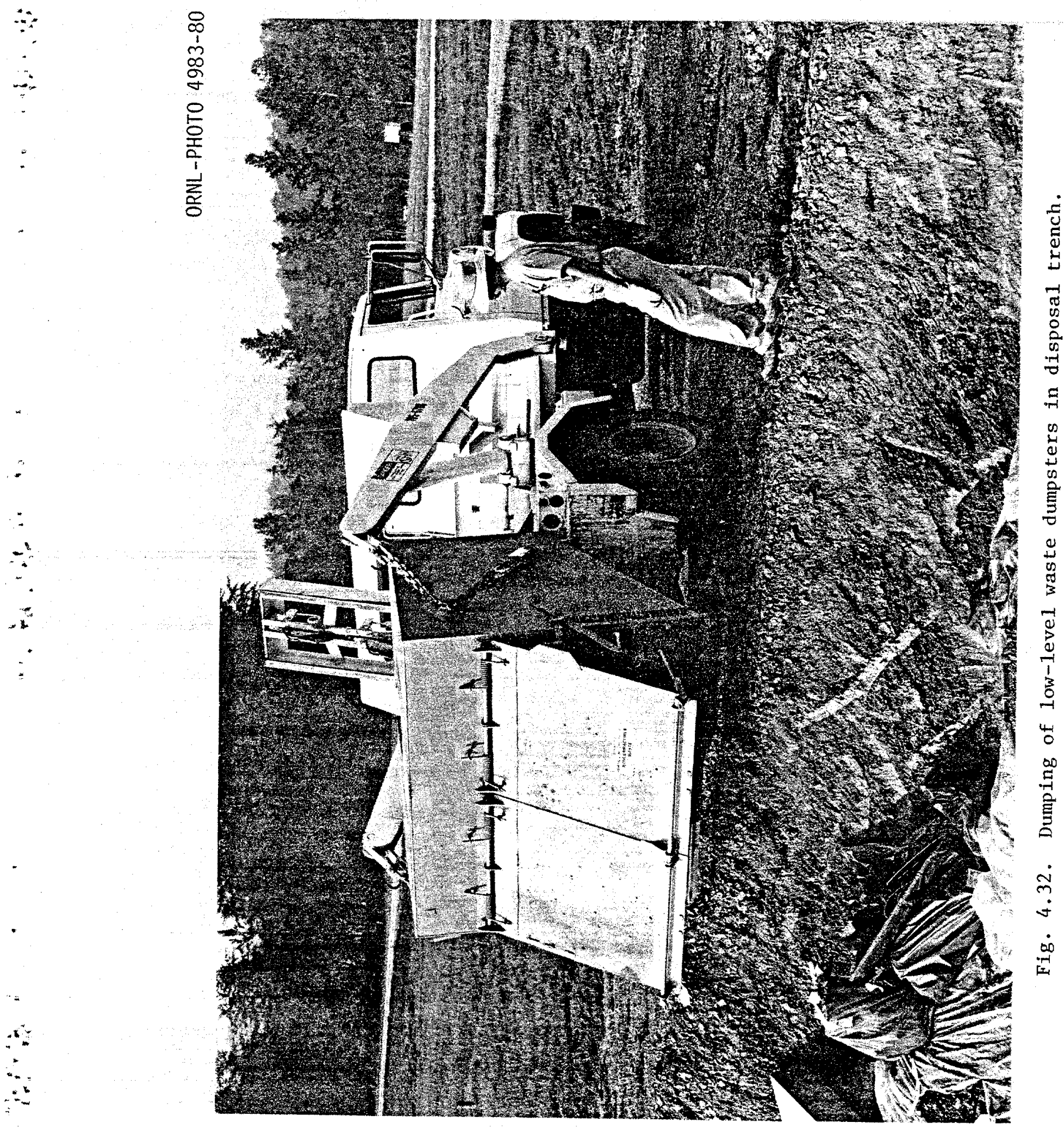




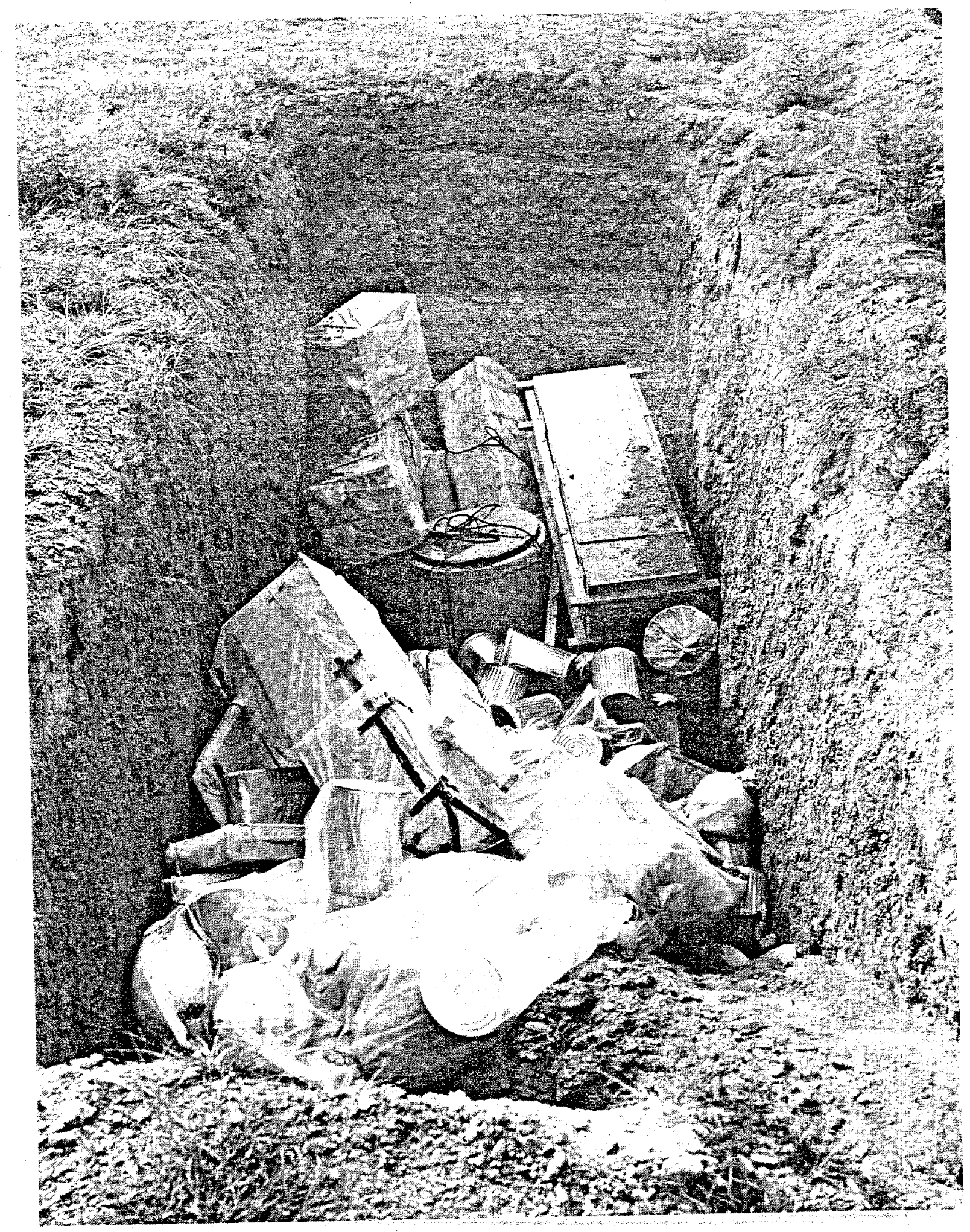

Fig. 4.33. Typical waste in disposal trench before back filling. 


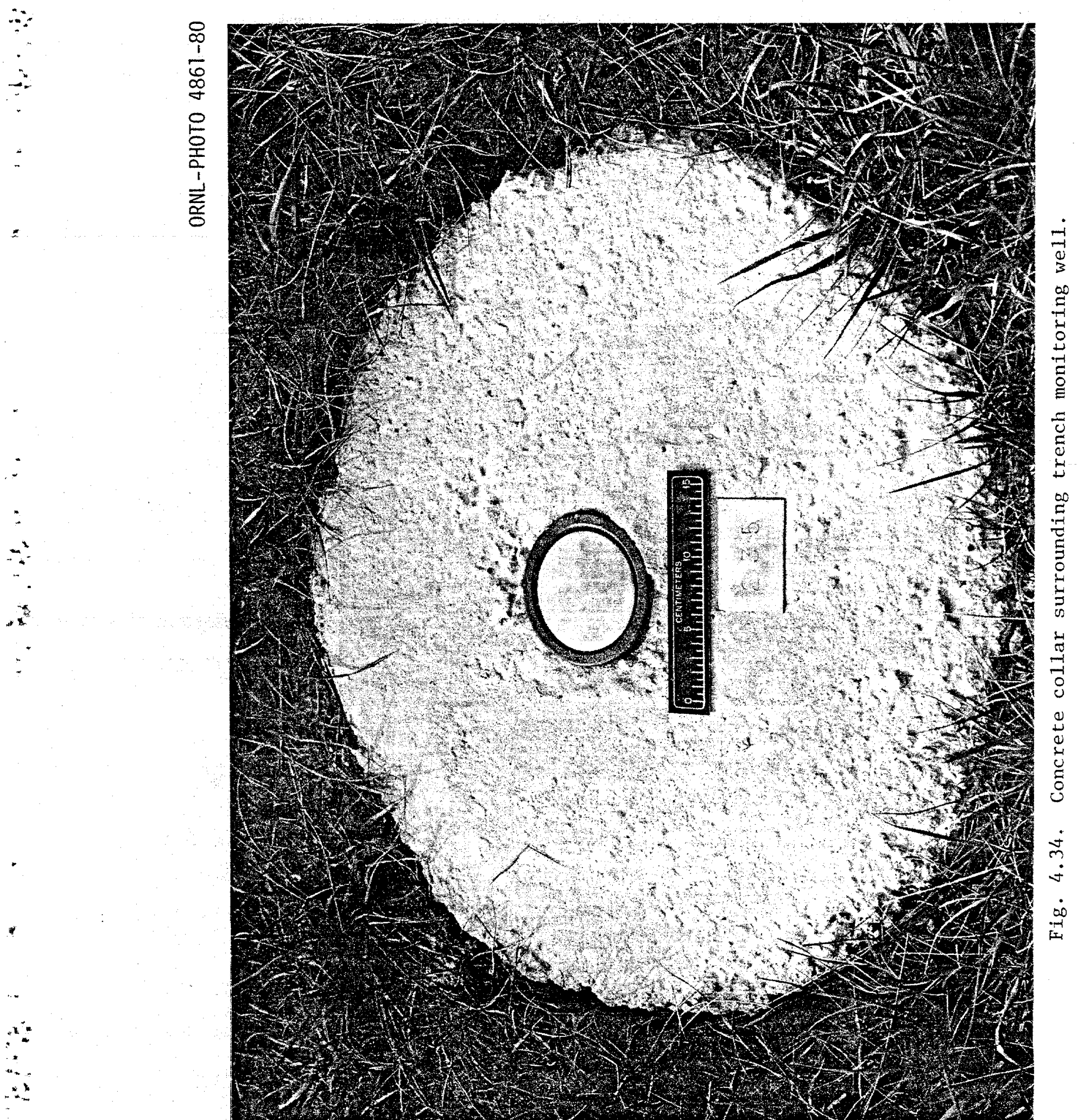


Surveillance of the closed trench is initiated immediately after closure. If surveillance indicates additional action is required to prevent entry of water, appropriate action is taken. This may involve additional ditching, improving contouring, compacting the trench backfill, or installing the aforementioned impervious membrane ahead of normal schedule.

An engineering survey is conducted on the location of each trench and the results are recorded and maintained by ORNL Engineering.

\subsubsection{Auger Holes}

Auger hole disposal is utilized for either high-level waste or fissionable (primarily 235U) waste following the same basic principles as outlined for trench disposal. The auger holes are constructed and maintained, with due regard for local hydrology and topography, to ensure maximum possible isolation of the waste from infiltration of ground and surface water.

Auger hole diameters are variable, depending primarily on the function of the Individual hole, but are normally $1 \mathrm{~m}$ (40 in.) or less. Depth of the hole is limited to at least $0.6 \mathrm{~m}$ ( $2 \mathrm{ft}$ ) above the currently known high water table. Auger holes are spaced a minimum of $0.9 \mathrm{~m}$ ( $3 \mathrm{ft}$ ) from edge to edge.

Auger holes are closed when the hole has been filled to within 0.9 m (3 ft) of the surface or, in the case of fissile material, when the hole contains 200 grams of fissile isotopes, whichever occurs first. High-level and fissile auger holes are closed by backfilling with native sol1 to within approximately $0.6 \mathrm{~m}$ ( $2 \mathrm{ft}$ ) of the surface, then $0.25 \mathrm{~m}$ (8 to $12 \mathrm{in.)}$ of concrete is added, and finally the remainder of the hole is filled with native soll and the surface is grassed.

Each auger hole is assigned a unique number with records being maintained of the contents of each hole. Hole locations are indicated on site drawings maintained by ORNL Engineering. 


\subsection{RETRIEVABLE SOLID WASTE STORAGE FACILITIES}

\subsubsection{Introduction}

The Atomic Energy Commission Immediate Action Directive of October 1970 requires that all radioactive waste contaminated above $10 \mathrm{CI} / \mathrm{g}$ with transuranic isotopes be stored in a fashion to allow future removal of the waste for subsequent processing or shipment for a period of 20 years. This requirement has been met at ORNL by a group of special facilities located in the security area of SWSA-5/north (Fig. 4.26). Depending on their radiation backgrounds, TRU wastes are packaged retrievably in 30- or 55-gallon stainless steel drums, in concrete casks of various wall thicknesses, or in stainless steel cylinders. The lowlevel drums are stored in one of two storage facilities, Buildings 7826 or 7834. The concrete casks are disposed of through trench burial in a designated area in SWSA-5/north or more recently in a concrete storage facility, Building 7855. The high-level material is placed in stainless steel lined auger holes, Buildings 7827 and 7829 . Each of these special facilities will be described in detail in the following sections.

\subsubsection{Staging Facility}

The staging facility, Building 7823 (Fig. 4.26), is a partially underground shed currently used for temporary storage of low-level transuranic waste, primarily drums, before it is placed in permanent storage facilities. Initially, the building was used for extended storage of various types of $10 \mathrm{w}-1$ evel $(<200 \mathrm{mrem} / \mathrm{h})$ retrievable waste including drums, metal boxes, etc. All these items have been removed to permanent storage and the facility is currently used only for temporary holding of packaged wastes until enough have acumulated to justify transfer to one of the permanent facilities.

Building 7823 is approximately $15.3 \mathrm{~m}(50 \mathrm{ft}$ ) wide by $24.4 \mathrm{~m}$ ( 80 ft) long in the main building with an extension on the south side for a truck entrance. The total area of the building is approximately 390 $\mathrm{m}^{2}\left(4200 \mathrm{ft}^{2}\right)$. The facility is approxinately two-thirds below grade 
and has a gable roof open at each end. The walls are curved, galvanized metal culvert sections of 12-gauge corrugated steel. The roof is $0.08 \mathrm{~cm}(0.032 \mathrm{in.})$ corrugated aluminum with four sections of plastic skylight. There is an interior ceiling of 9-gauge galvanized steel wire fencing located $4.25 \mathrm{~m}$ (14 ft) above the floor to prevent removal of the waste containers during a tomado. The floor is a $0.3 \mathrm{~m}$ (12 in.) deep bed of crushed rock. There are no utilities inside the building (Fig. $4.35)$.

\subsubsection{Drum Storage Facility No. 1}

Building 7826 is a facility designed for retrievable storage of low-level transuranic waste in 55-gallon drums (Fig. 4.8). The building is a one-story concrete block and reinforced concrete structure approximately $11.6 \mathrm{~m} \times 17.4 \mathrm{~m} \times 4 \mathrm{~m}$ (38 ft $\times 57 \mathrm{ft} \times 13 \mathrm{ft}$ ) high. The structure is approximately $85 \%$ below grade ( $\mathrm{Fig} \cdot 4.36$ ). The facility is divided into 24 compartinents or cells (Figs. 4.37 and 4.38 ). Each cell will accomodate sixty-four 55-gallon drums, stacked in four layers with sixteen drums per layer. A thin sheet of plywood is placed between each layer. Each cell contains a floor drain and a sump to monitor for ground-

water leakage and possible movement of radionuclides from the facility. Each sump can be sampled individually and the drains can be monitored and sampled at external catch basins. There are no utilities in the facility.

Access to the cells is by removal of roof sections, with each section accomodating two cells. The roof sections are composed of a structural steel framework covered with 22-gauge galvanized metal decking. The spacing on the roof franework is designed to prevent removal of the drums in the event of a tornado. When sufficient drums have accumulated in the staging facility, one of the roof panels is removed and the drums are placed in the cells with a crane, four at a time. 
? in

$\cdots, D_{2} \therefore \therefore$

ORNL-PHOTO 2566-71

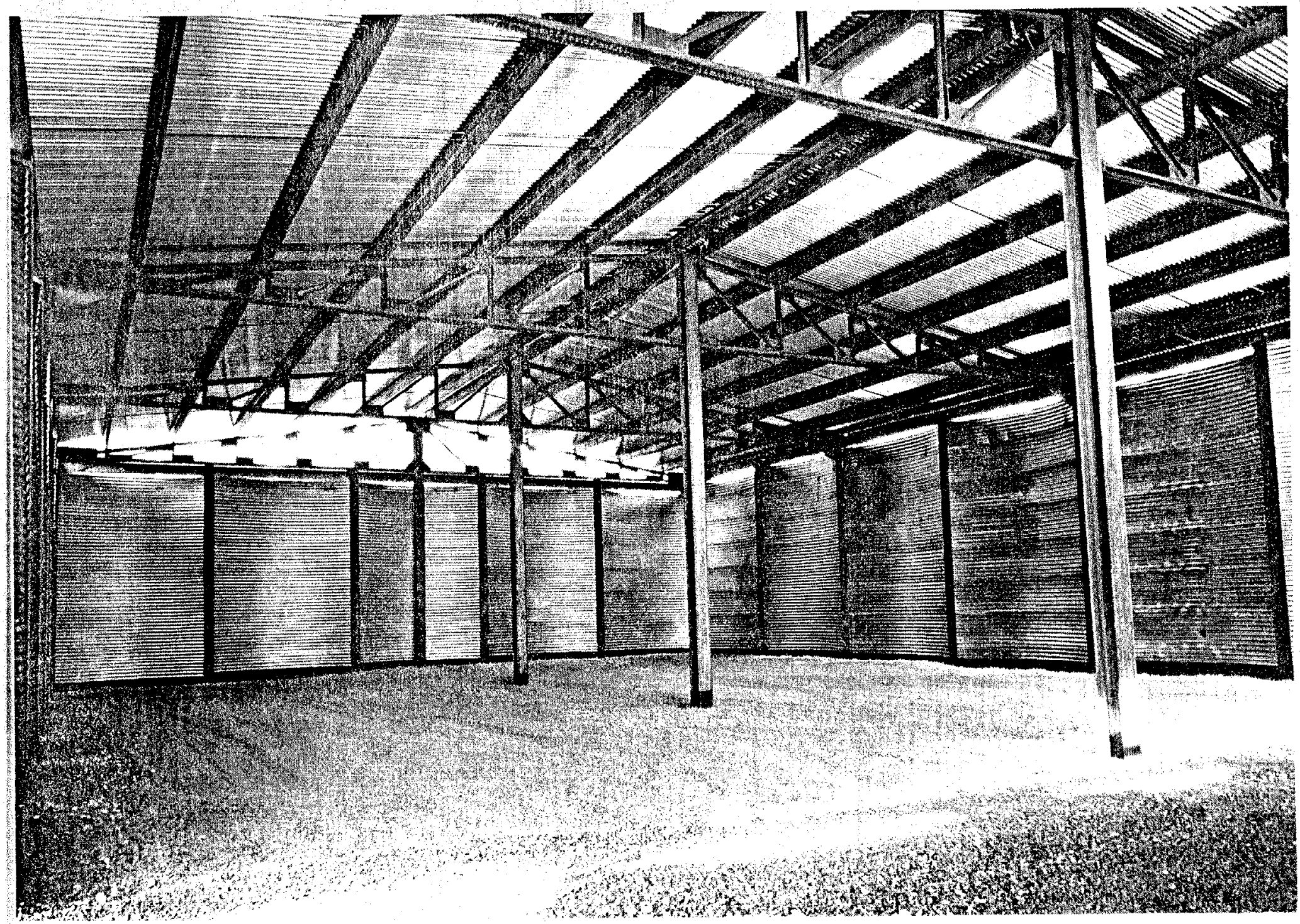

Fig. 4.35. Interior of staging facility (7823). 
ORNL-PHOT0 4862-80A

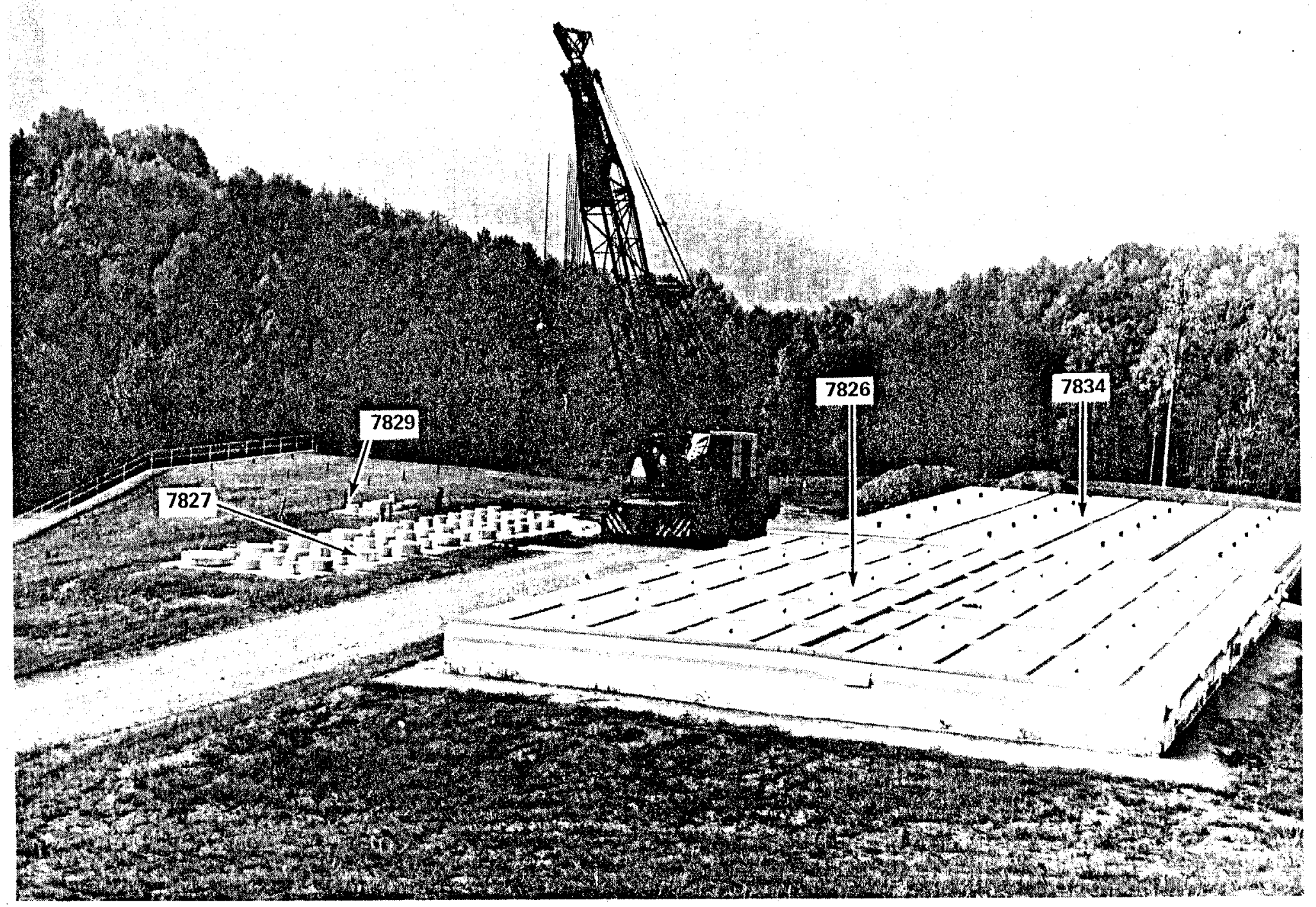

Fig ".36. Drum storage buildings (7826 and 7834)

high-1evel storage we11s (7827 and 7829). 
$\frac{\overline{5}}{\mathbf{8}}$
$\mathbf{8}$
$\frac{5}{5}$
$\frac{1}{5}$

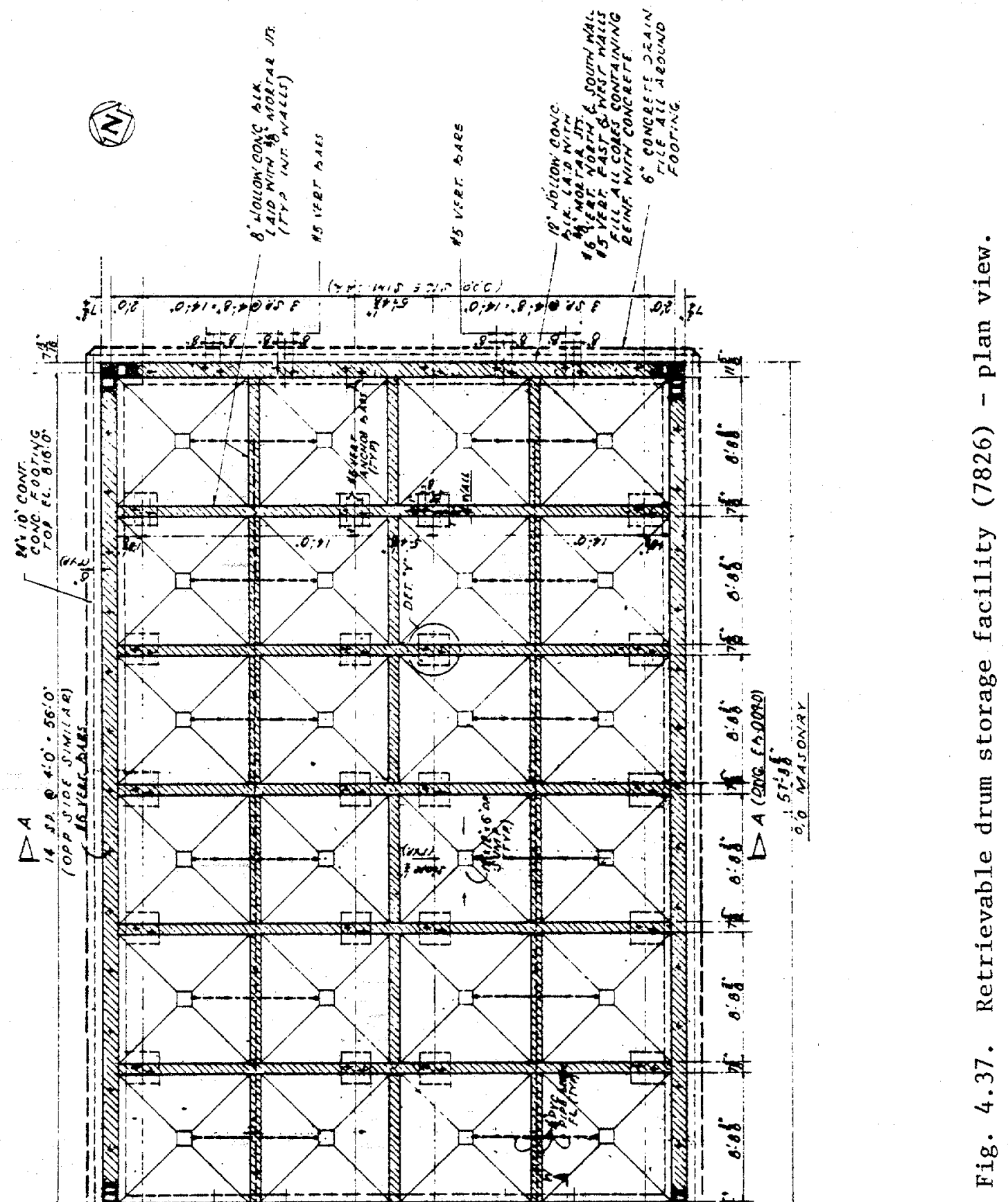

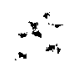

$\because$

$\therefore$

$\because$

$\because$

点 


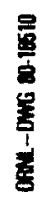

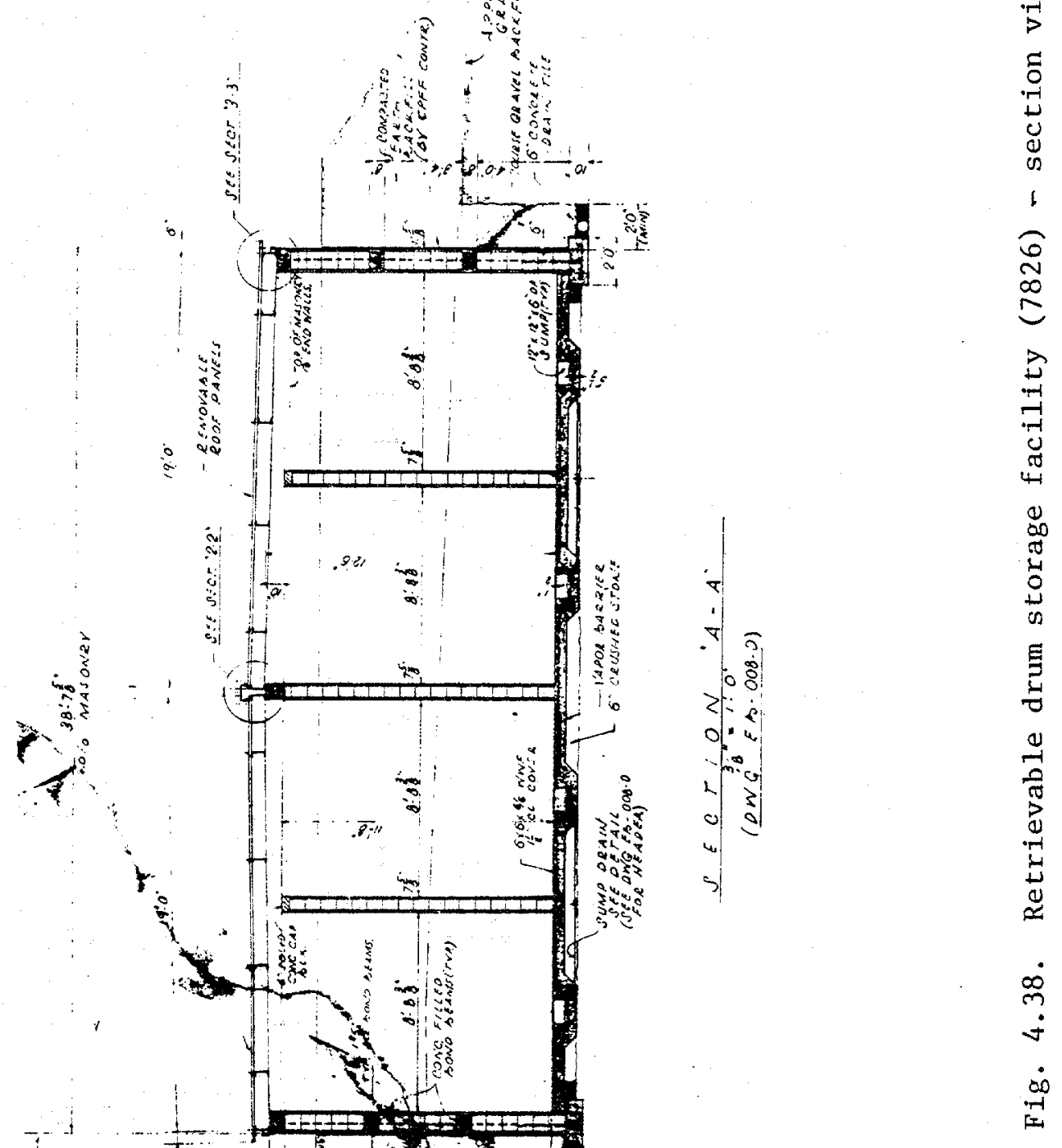


The structure is designed for seismic loading in accordance with the Uniform Building Code for Seismic Zone 2 and tornado resistance in accordance with NRC Regulatory Guide 1.76. Criticality control is accomplished through restrictions on the amount of fissionable material allowed in each drum based on calculations assuming an infinite array of drums.

\subsubsection{Drum Storage Facility No. 2}

As Building 7826 neared its capacity of drums, a new storage facility was designed and constructed adjacent to 7826 (Fig. 4.36). This facility, Building 7834, was completed in early FY-80 and is currently available for use as needed. It is expected to have sufficlent capacity for approximately eight years at current generation rates.

Building 7834 utilizes the same basic design as 7826 with two exceptions. The roof of Building 7834 consists of removable concrete plugs with sufficient weight to prevent removal during a tornado. One plug is utilized for each cell. The plugs contain a $10 \mathrm{~cm}$ ( $4 \mathrm{in.}$ ) pipe sleeve to allow sampling of the sumps in each cell without removal of the plug (Fig. 4.39). Building 7834 contains 24 cells with a sump and drain arrangenent similar to 7826. Building 7834, however, accommodates drums in five layers instead of the four layers in 7826 . This gives a capacity of 80 drums per cell.

Placement of drums is similar to the procedure for Building 7826. When sufficient drums have accumulated in the staging facility, one of the concrete cell plugs is removed and the drums are placed in the cell, four at a time, with the layers separated by plywood. Building 7834 is designed to the tornado and earthquake requirements of NRC Regulatory Guide 1.76 and the Uniform Building Code for Seismic Zone 2, respectively. 
OFN-DWG Ba-16000

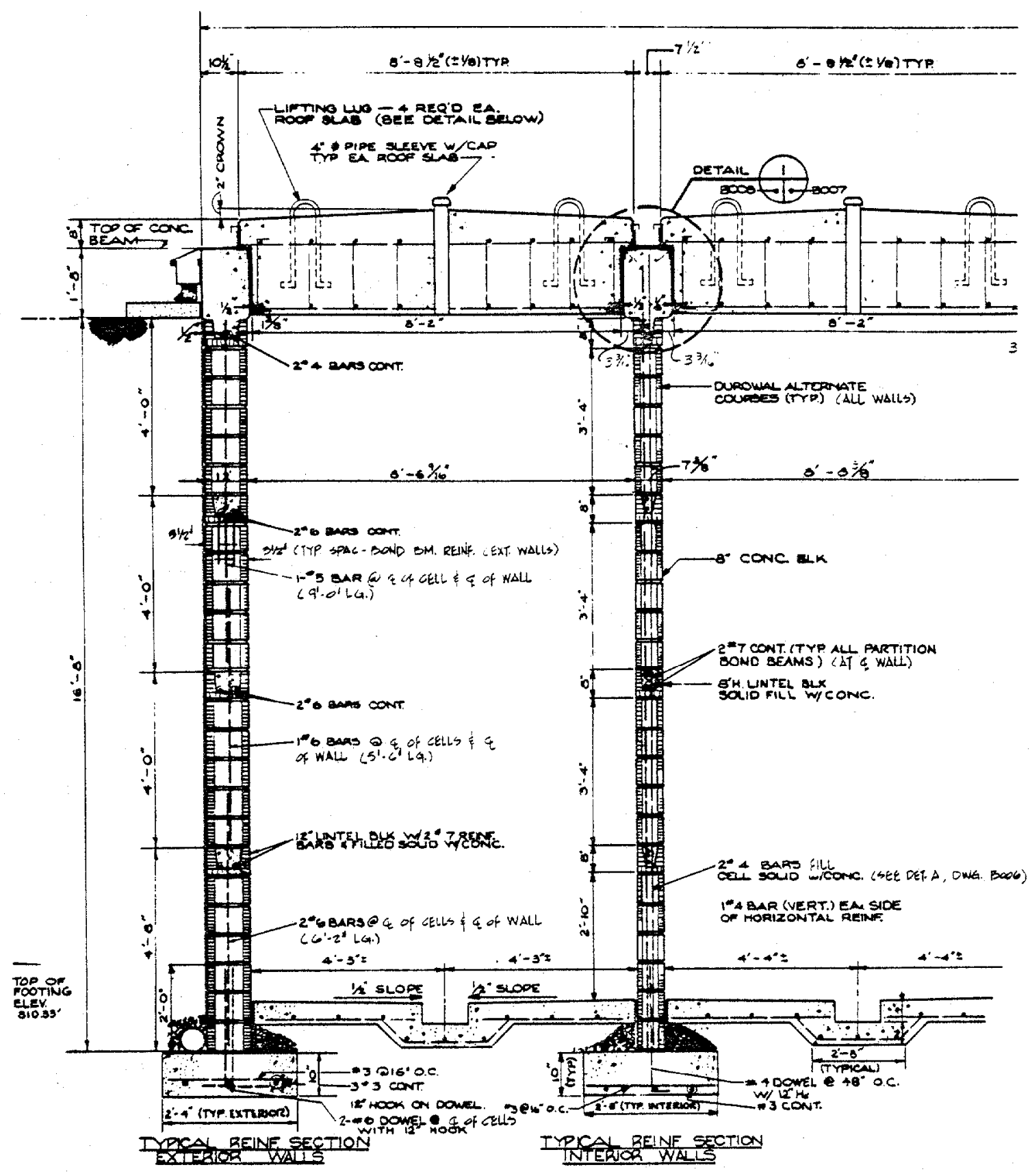

Fig. 4.39. Retrievable drum storage facility (7834) - section view. 


\subsubsection{Concrete Cask Storage Area}

The cleared area to the west of the drum storage buildings (FIg. 4.25) has been used since October 1970 through FY-79 for the retrievable burial of concrete casks containing higher level transuranic waste. Disposal procedure for the casks is normal trench burial described in Section 4.3.2. The concrete package ensures that the wastes w111 remain retrievable in the future. Earlier practice prior to october 1970 involved placing the casks in the trench and then pouring concrete over and around the casks. These casks are not in the SWSA-5/north area and are not considered to be retrievable. Figure 4.40 illustrates the storage method for the casks. A total of sixteen trenches containing concrete casks are located in this storage area.

\subsubsection{Concrete Cask Storage Building}

With the ever increasing emphasis on retrievability of transuranic wastes, it was determined that burial of the concrete casks was not completely acceptable due to the difficulty in exhuming the containers. on this basis, a concrete storage building was constructed which will be used for concrete casks generated subsequent to FY-79. This storage building, Building 7855, was located in the southeast of the cask burial area (Fig. 4.26) and was completed in January 1980.

Building 7855 is a concrete block and reinforced concrete structure containing four bays for cask storage. Figures $4.41,4.42$, and 4.43 illustrate the design of the facility. The building is largely below grade with access on the southern face of the structure. Each bay contains a sump and drain system for collection of groundwater leakage into the facility. Pipe sleeves in various locations in the roof above the sump allow sampling of the sump contents or sampling of the atmosphere in the facility. No closure is provided on the exposed face of the facility. 


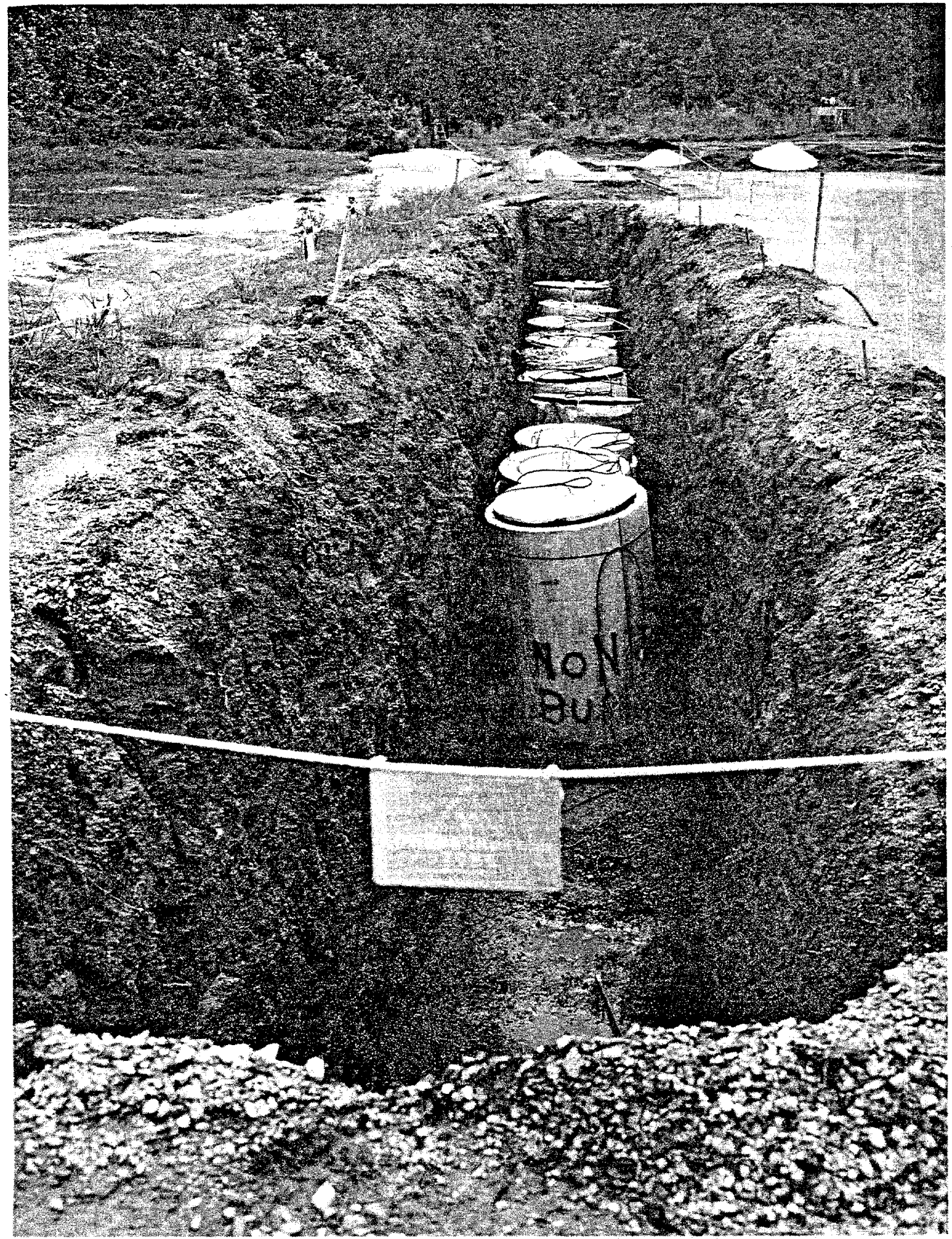

Fig. 4.40. Retrievable burial of concrete casks. 


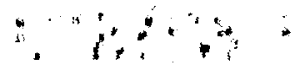

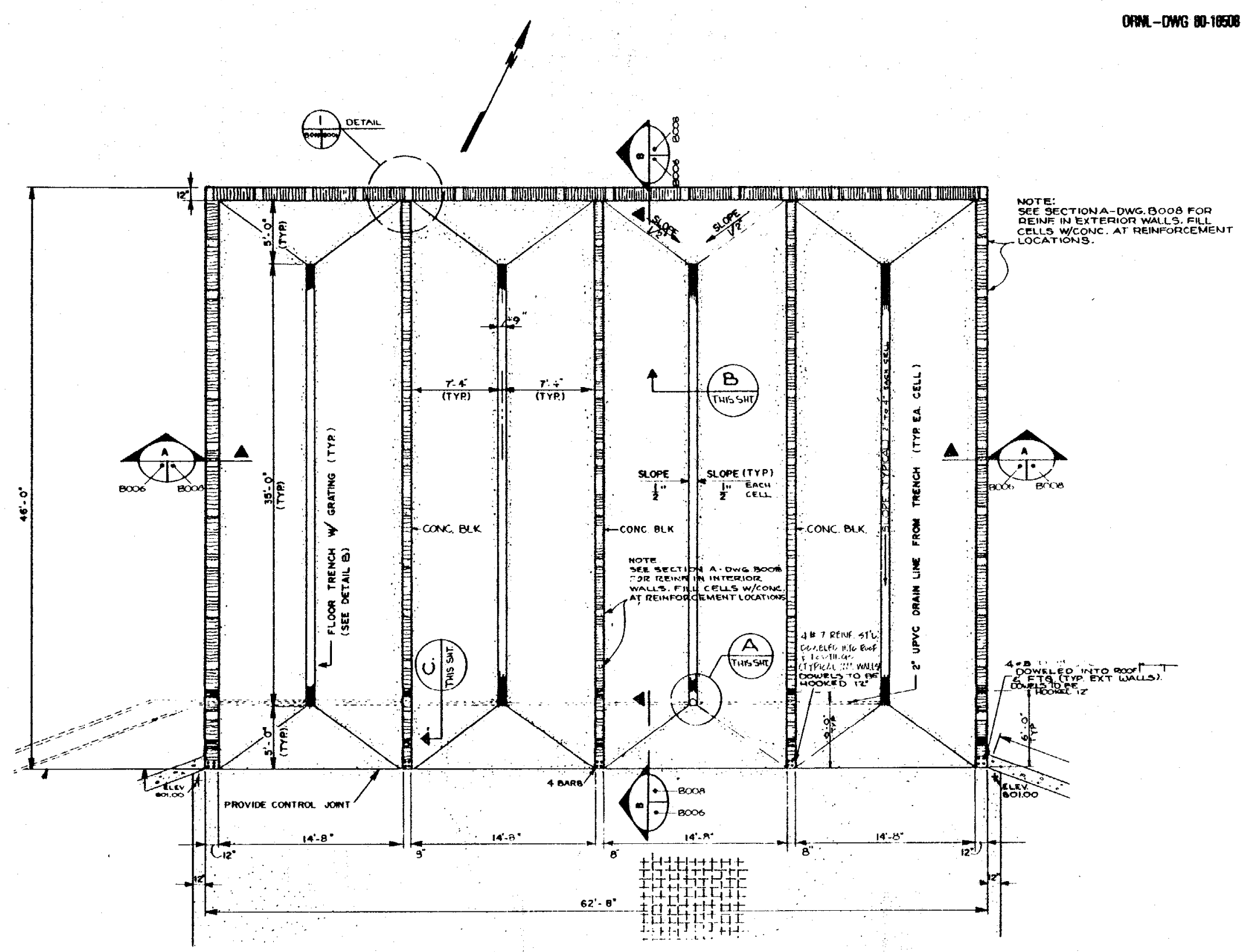

Fig. 4.41. Concrete cask storage building (7855) - plan view. 


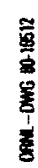
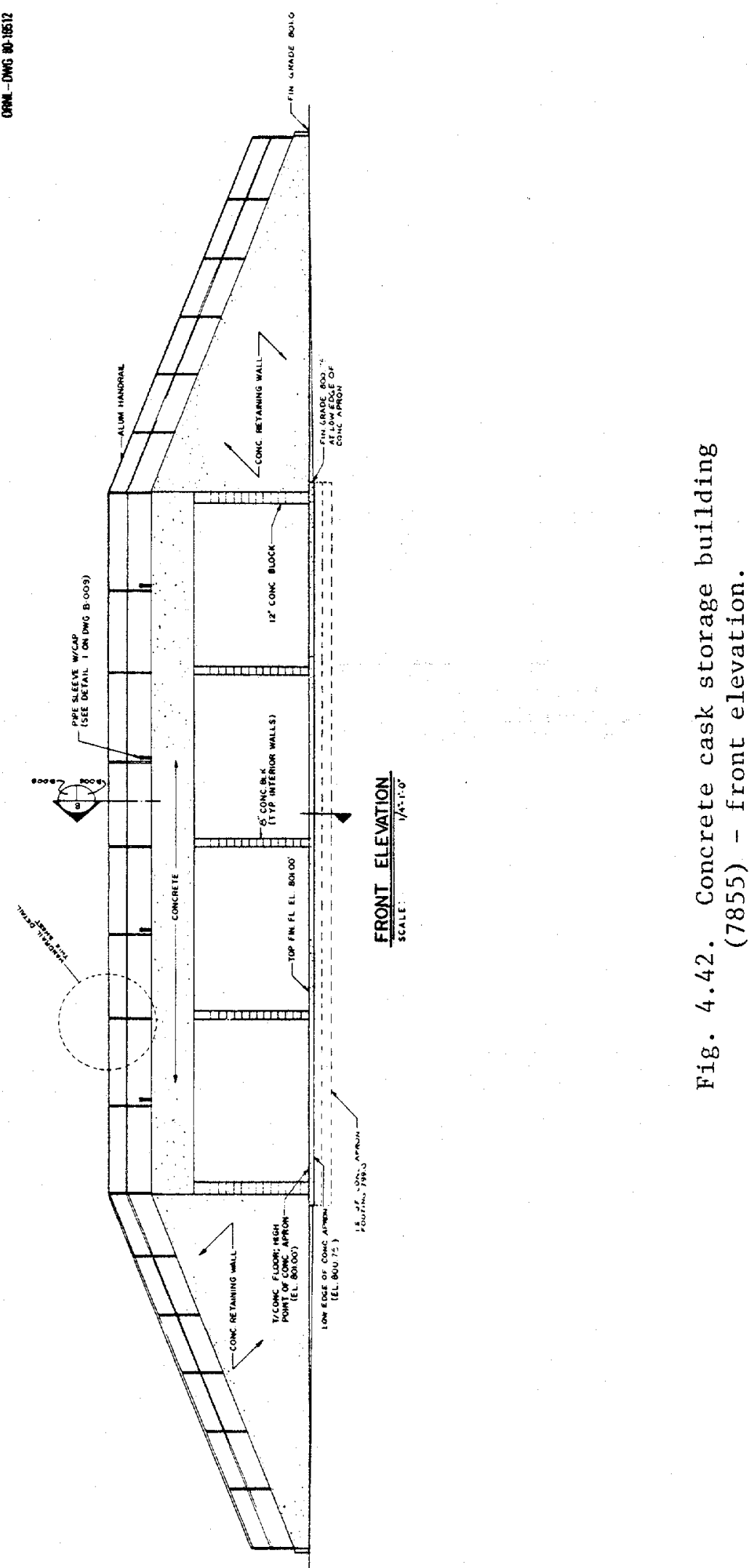

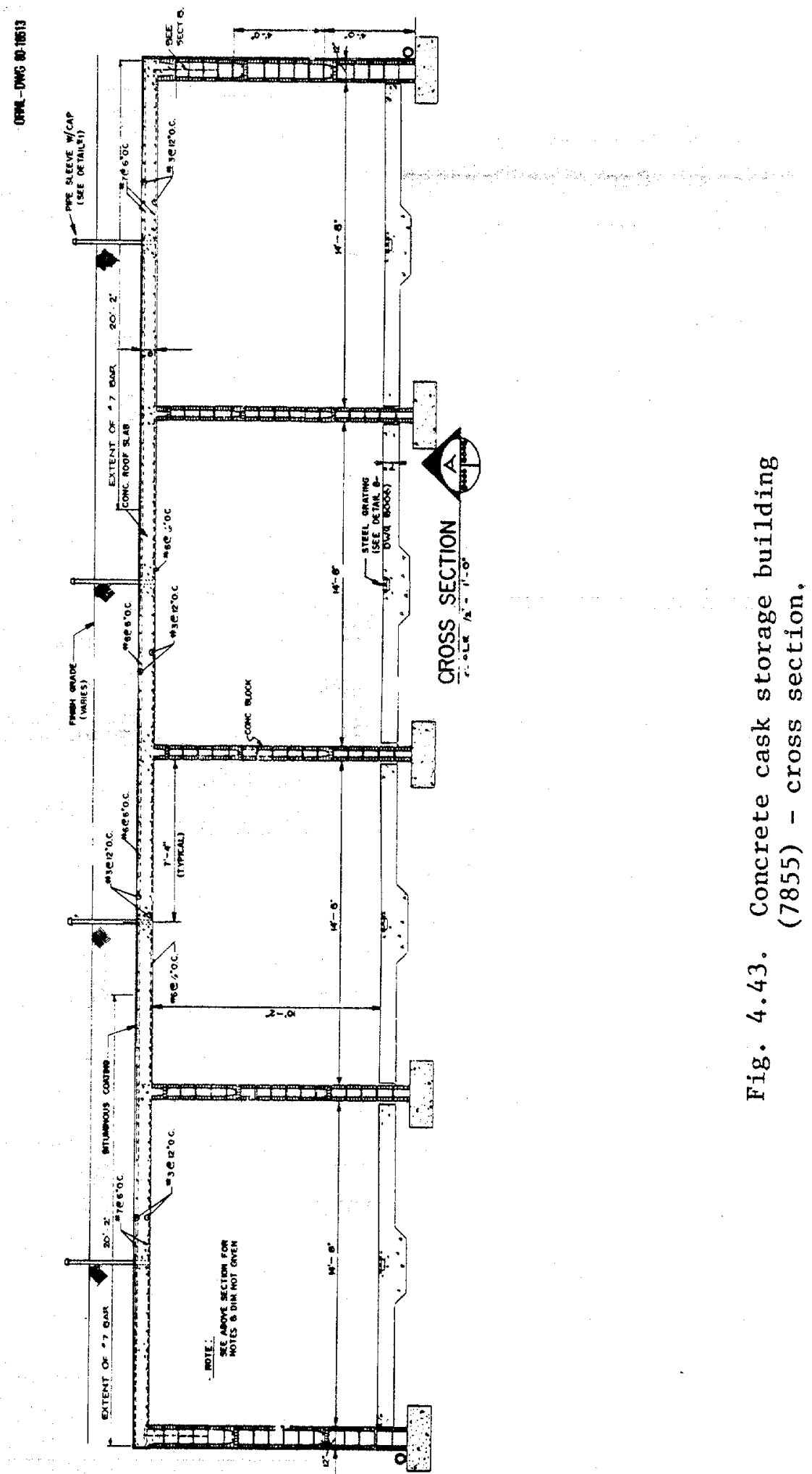
Each bay of the building is approximately $4.6 \mathrm{~m}$ (15 $\mathrm{ft}$ ) wide by $3 \mathrm{~m}$ (10 ft) high by $13.75 \mathrm{~m}(45 \mathrm{ft}$ ) deep and has a capacity of 27 casks giving a total capacity for the facility of 108 casks. This capacity should be sufficient for approximately five years at current generation rates. Casks are transported to the facility utilizing the same procedure as burial storage and are placed in one of the bays using a forklift with a special lifting attachment. When a bay is filled or when the radiation level becomes excessive inside the bay, a concrete block wall will be constructed across the bay opening to provide shielding. If an intermediate wall is found to be necessary, casks would continue to be placed in the bay outside the intermediate wall until it is filled and then a final wall would be constructed across the outside face of the bay. If and when retrieval becomes necessary, the wall would be removed and the casks would be retrieved using the reverse of the above process. The facility is designed for seismic loading in accordance with the Uniform Building Code for Seismic Zone 2 and tornado loading as described in NRC Regulatory Guide 1.76. Figure 4.44 shows concrete casks in place in one bay of the facility.

\subsubsection{High Level Wells}

Transuranic waste containing very high beta-gamma background radiation is placed in a group of stainless steel lined storage wells designated as Buildings 7827 and 7829. These facilities are located just to the south of the drum storage buildings as shown on Fig. 4.26.

A typical stainless steel well is either 3 or $4.6 \mathrm{~m}$ ( 10 or $15 \mathrm{ft}$ ) deep and may be either $20,25,30.5,35.5,40.5$, or $76 \mathrm{~cm}(8,10,12$, 14, 16, or $30 \mathrm{in.)}$ in diameter. The well is rolled from 16-gauge stainless steel and seam-welded. The bottom is welded to the liner and all welds are dye-checked. The stainless steel well is placed on a $15 \mathrm{~cm}$ (6 in.) thick concrete slab. Native soil is backfilled around the well and another similar concrete $s$ lab is poured around the well at grade

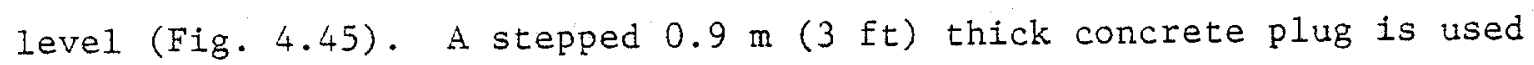
to seal the well. Spacing of the holes is limited to a minimum of $0.9 \mathrm{~m}$ ( 3 ft) edge to edge to assure criticality control. 


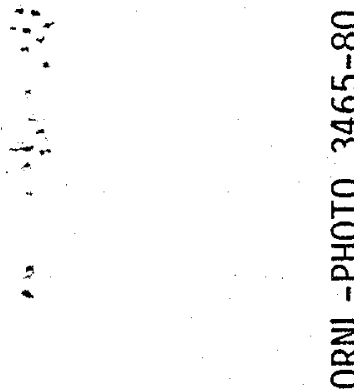

$\because$

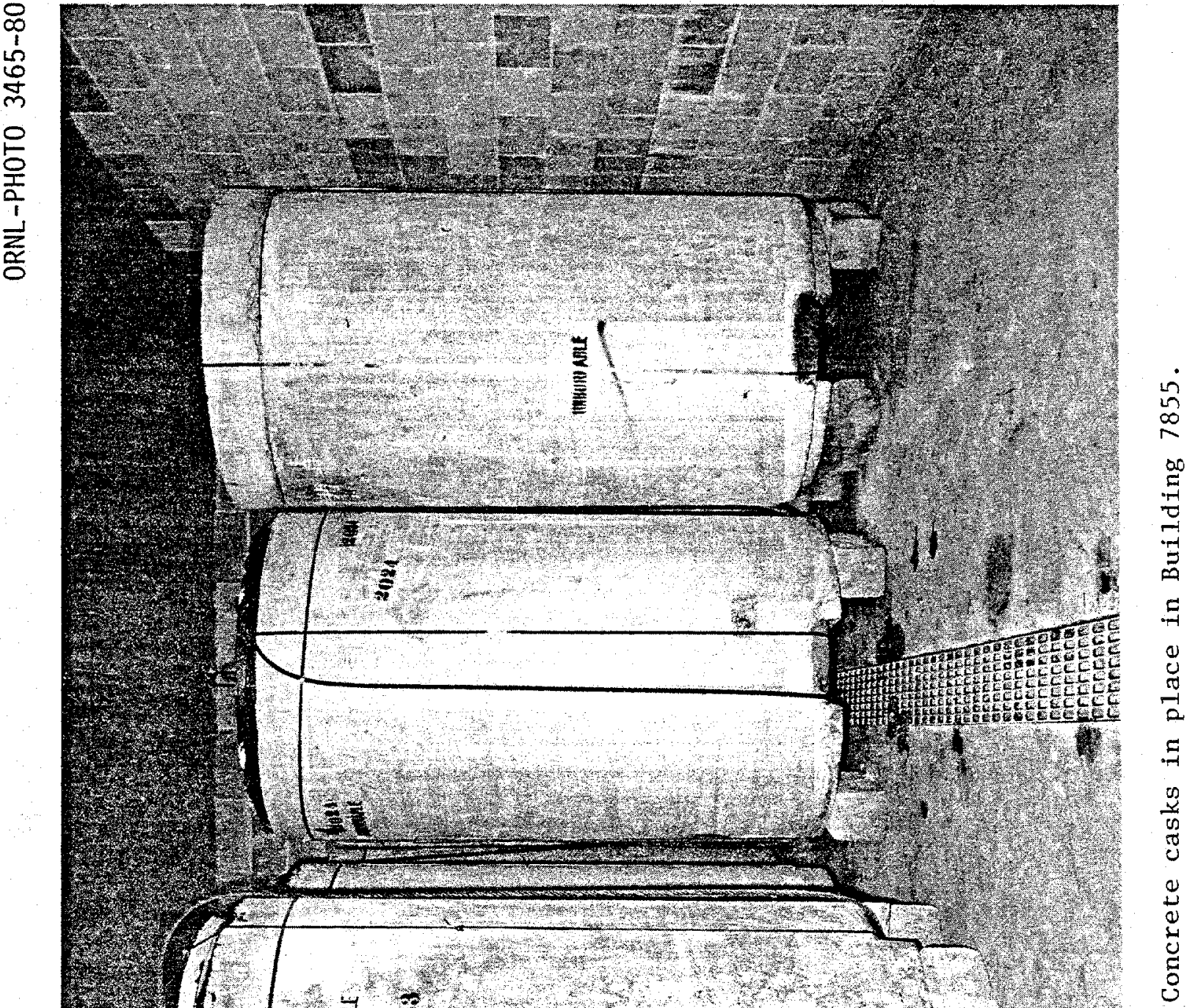

$=$

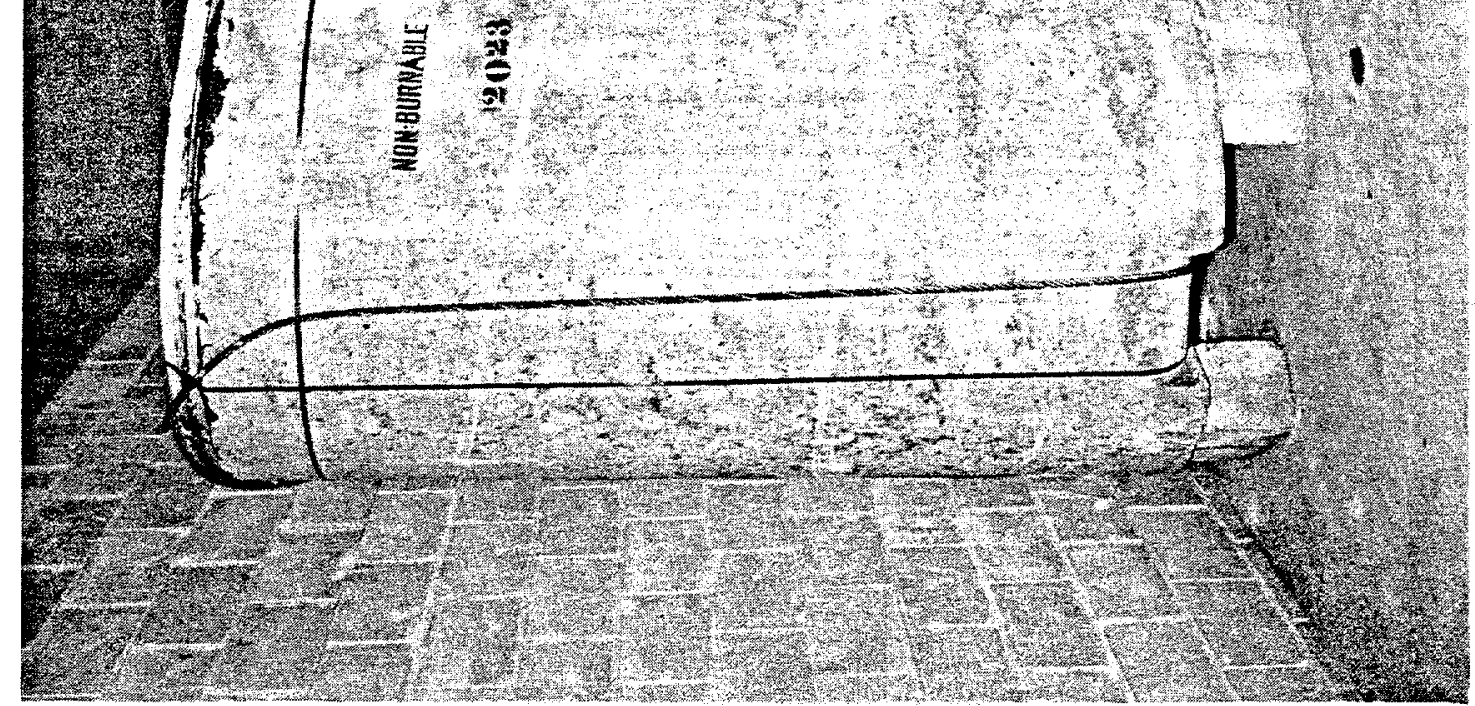




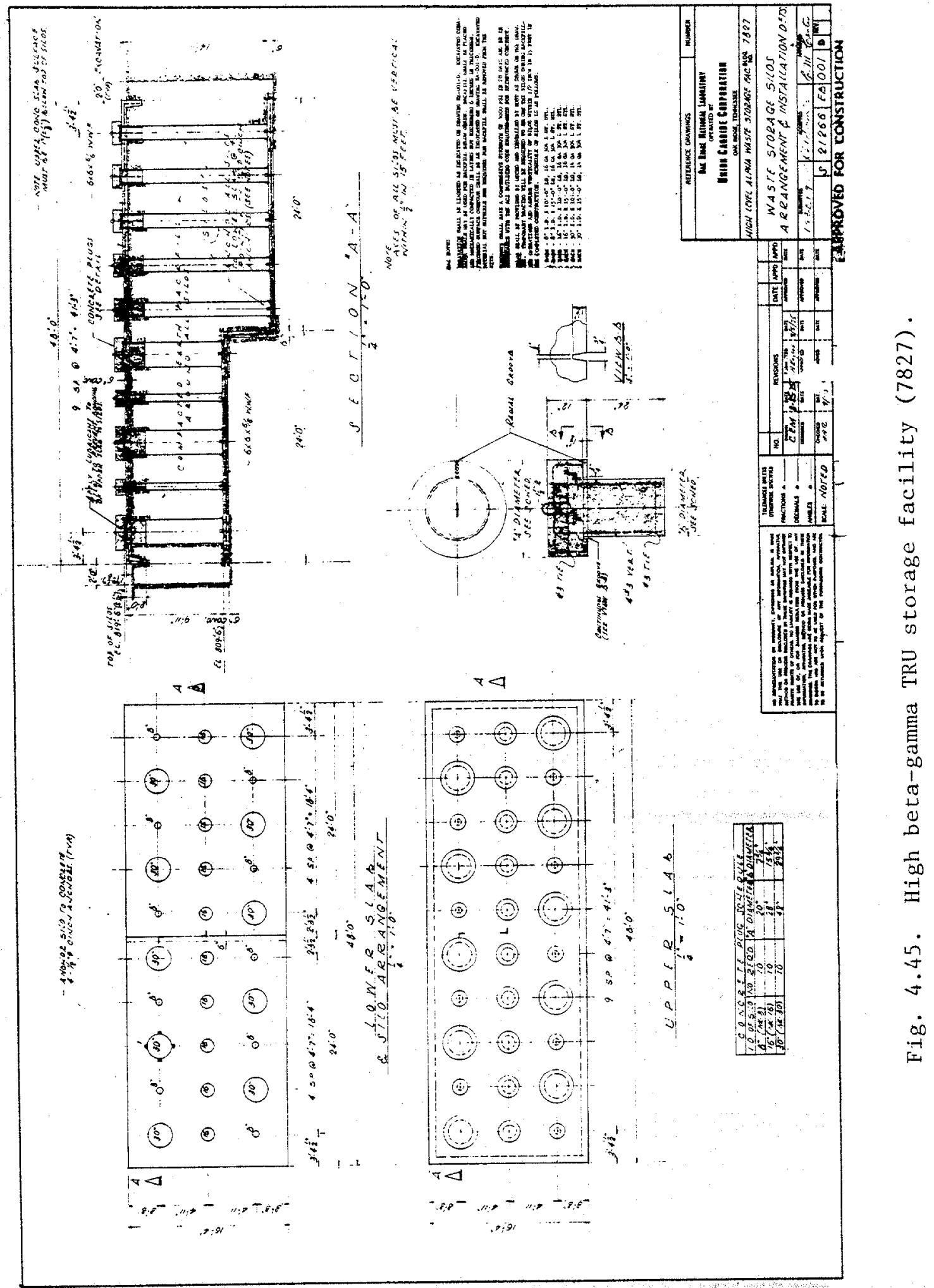


Waste to be placed in a storage well is packaged in stainless steel 55-gallon drums or other smaller stainless steel cylindrical packages. These packages are designed and built for a specific situation and are either all welded construction or possibly have a bolted flanged cover. The waste in the package is transported to the well in a shielded container and lowered into the well. The concrete plug is then placed in the well with the lifting cable from the canister and the identification tag exposed. Wastes are removed through a reverse of the above process, by placing the shielded carrier over the well and lifting the canister into the bottom of the carrier using the attached cable.

Bullding 7827 is a two section structure, constructed primarily below grade, and containing 30 wells in one section with 24 wells in the second section. The wells in the first section have diameters of $20,40.5$, and $76 \mathrm{~cm}(8,16$, and $30 \mathrm{in.})$. Half of the wells are $3 \mathrm{~m}$ (10 ft) deep and the other half are $4.6 \mathrm{~m}$ (15 ft) deep. All 24 wells in the second section are $20 \mathrm{~cm}(8 \mathrm{in.})$ in diameter by $4.6 \mathrm{~m}$ (15 ft) deep. Figure 4.46 is a cross-section of the first section of the facility.

Building 7829 is similar in design to Building 7827 but contains only ten wells. All ten wells are $30.5 \mathrm{~cm}$ (12 in.) in diameter by $4.6 \mathrm{~m}$ (15 ft) deep.

\subsection{SOLID WASTE COMPACTION}

\subsubsection{Introduction}

The very limited availability of areas suitable for the disposal of solid radioactive waste at ORNL has caused the initiation of several programs to reduce the volume of buried radioactive waste. One of the most significant of these volume reduction campaigns has been the design and operation of a radioactive solid waste compactor. The Compaction Facility, Building 7831, is located just outside the entrance of the transuranic waste storage area in SWSA-5/north. Compactible waste, primarily very low level, is segregated by the generator into special 
collection dumpsters and is transported to the facility for compaction and subsequent disposal in special trenches in SWSA-6. No fissile or transuranic contaminated wastes are allowed in the compactor facility.

\subsubsection{Solid Waste Compactor Facility}

The Solid Waste Compactor Facility was designed and constructed for receiving and processing general low-level compactible waste having a beta-gama background of $200 \mathrm{mrem} / \mathrm{h}$ or less. The building housing the compactor is approximately $12.2 \mathrm{~m} \times 13.1 \mathrm{~m}$ (40 ft $\times 43 \mathrm{ft}$ ) with an inside height of approximately $4.6 \mathrm{~m}(15 \mathrm{ft})$ in the compactor area. It is constructed of structural steel concrete block inside walls. The interior of the building consists of three zones: a work area housing the compactor machinery, the personnel area of the building which includes change room, lunch room, hallway, and office, and a storage and building service equipment area above the personnel area. The compactor area also includes space for two dumpster pans and short-term bale storage. Access to the upper storage level is by means of stairs inside the compactor area. One personnel door in each of the ground floor areas and one roll-up door in the compactor area provide access to and from the building. Figure 4.46 illustrates the layout of the facility. The area outside the compactor room is a covered concrete storage pad for storage of supplies and equipment and short-term storage of waste bales.

The compactor is a Model DHBS-2 MR upright hydraulic compactor from Consolidated Baling Machine Company, Brooklyn, NY. It is rated $4.45 \times 10^{5}$ newtons (50 tons) compressive force and has a chamber capacity sufficient to produce a nominal $0.38 \mathrm{~m}^{3}$ (1/2 cubic yard) bale 96.25 $\mathrm{cm} \times 52.23 \mathrm{~cm} \times 75.41 \mathrm{~cm}(37$ 1/2 in. $\times 20$ 9/16 in. $\times 29$ 11/16 in.) high. The primary hydraulic system operates at $1.38 \times 10^{7}$ pa (2000 psi), has a cylinder with $20.3 \mathrm{~cm}$ ( $8 \mathrm{in.}$ ) bore and $92.71 \mathrm{~cm}$ (36 1/2 in.) stroke, and is powered by a 11,200 watt ( 15 horsepower) electric motor. 


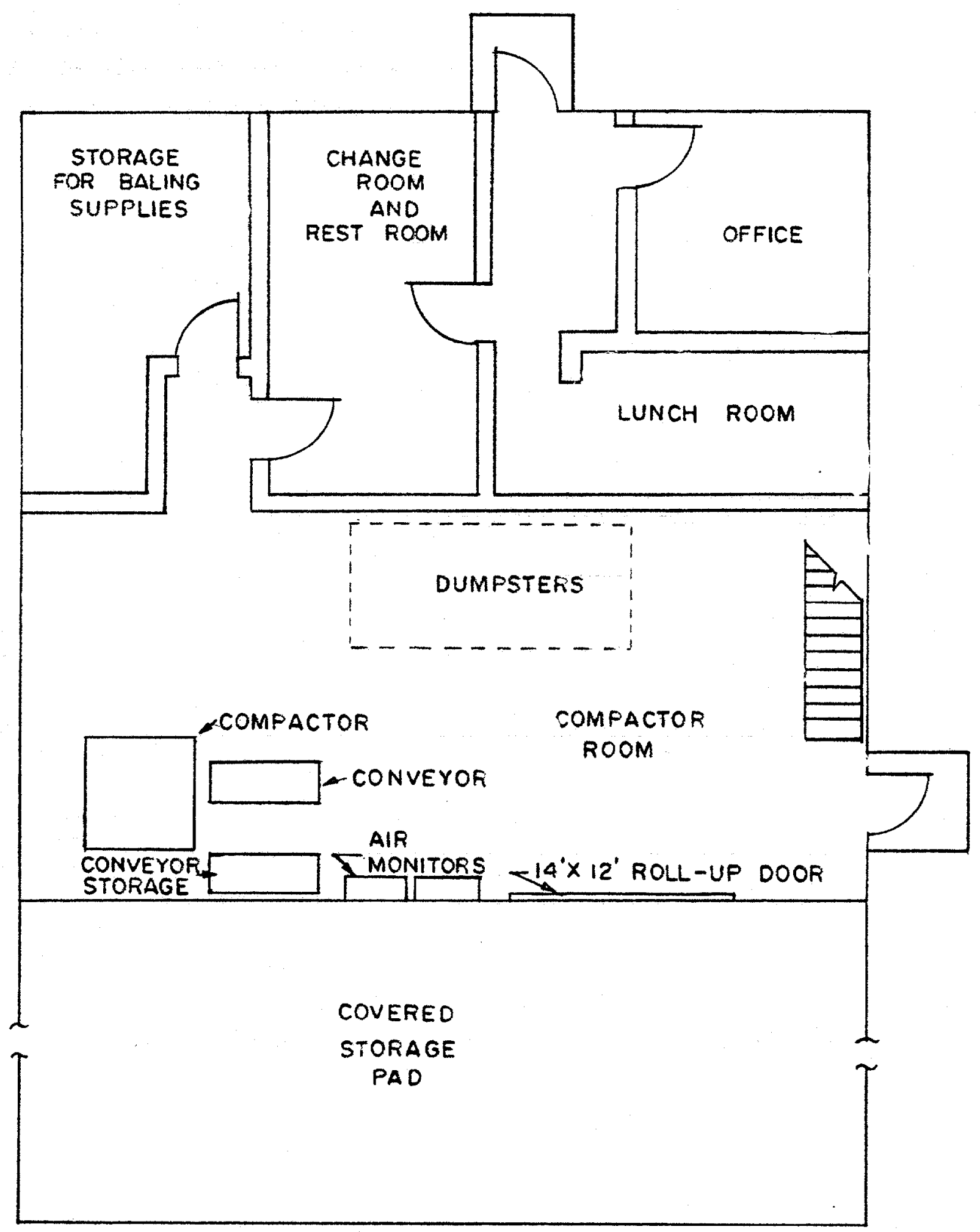

Fig. 4.46. Solid Waste Compactor Facility Building 7831 - floor plan. 
The compactor has a self-contained ventilation system capable of $1.2 \mathrm{~m}^{3} / \mathrm{s}$ ( $2600 \mathrm{CFM}$ ) at $15.2 \mathrm{~cm}$ (6 in.) of water pressure differential. The system exhausts air from inside the compaction chamber to the outside through two prefilters and two HEPA filters in parallel. A filter is placed upstream of the prefilters to trap any large particles which may enter the system. Differential pressure indicators across the filters actuate an alarm when a preset pressure drop across the filters is reached. The system maintains a minimum flow velocity of $0.5 \mathrm{~m} / \mathrm{s}$ ( $100 \mathrm{ft} / \mathrm{min}$ ) through the opening when the door is open.

The bales are banded in the compression chamber, while still under compression, and then are removed by a hydraulic bale ejector system onto a $1.5 \mathrm{~m}$ ( $5 \mathrm{ft}$ ) movable roller conveyor. Operation of the waste compactor is illustrated in Figs. 4.47 through 4.49. The waste is compacted into a box which is first placed inside the compaction cavity and lined with a polyethylene bag. The main door is then closed and waste is added through the upper door. Each bag of waste is compacted into the box as it is added. Then the box is filled with waste, it is strapped and ejected from the chamber onto the roller conveyor for removal.

\subsubsection{Disposal of Compacted Waste}

When a compacted bale is removed from the compactor, it is placed in a plastic bag which is closed with tape. The bale is then transported to SWSA-6 where it is placed in a designated trench. Sompacted waste trenches are similar to normal trenches except for a covering of corregated metal (Fig. 4.50). Compactible waste trenches generally fill slower than other trenches and the metal cover is required to prevent significant deterioration of the trench while it is open. The bales are placed in the trench using the same criteria as described in Section 4.3.2 (Fig. 4.51). When the trench is full, it is backfilled and grassed. 


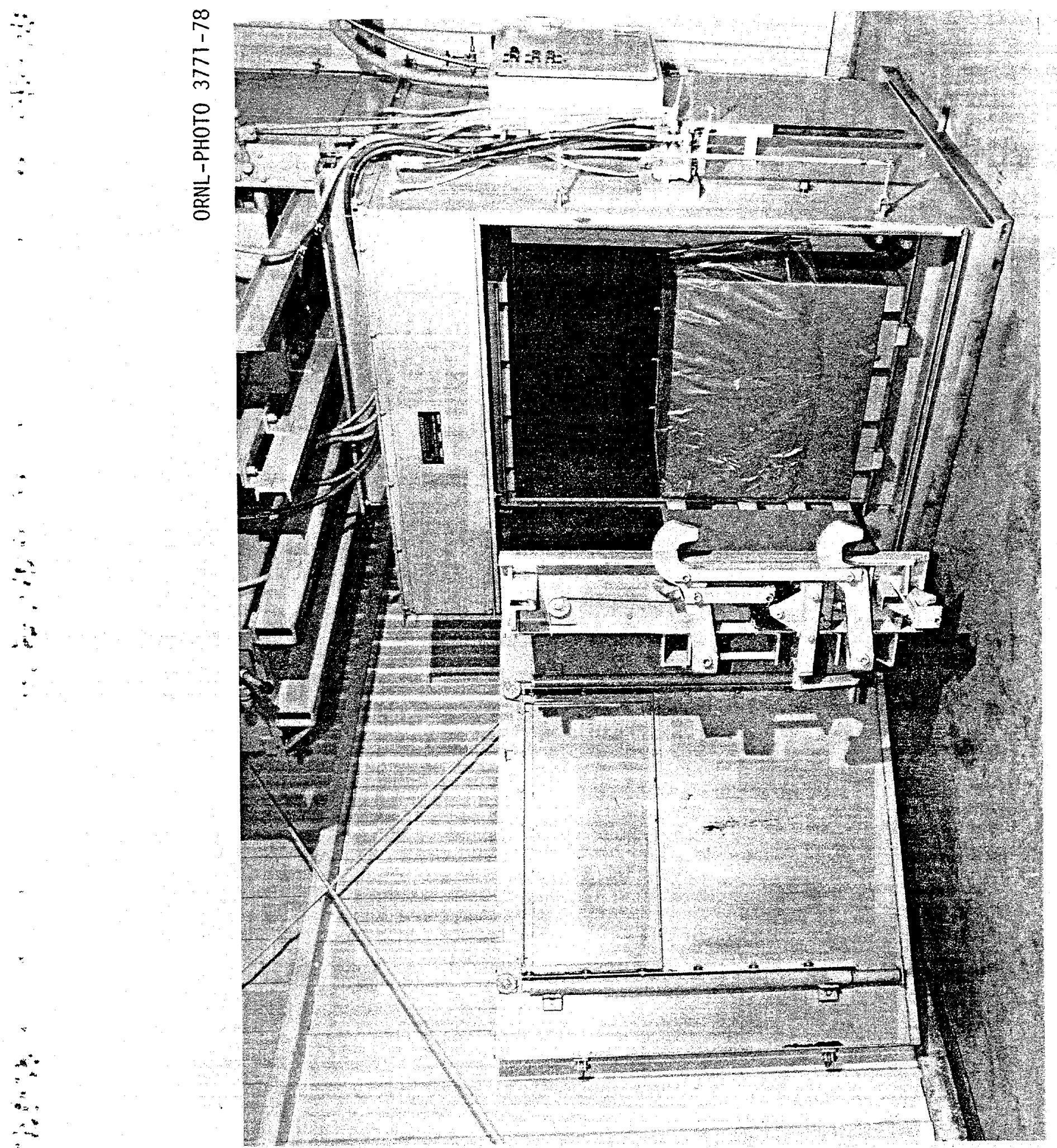




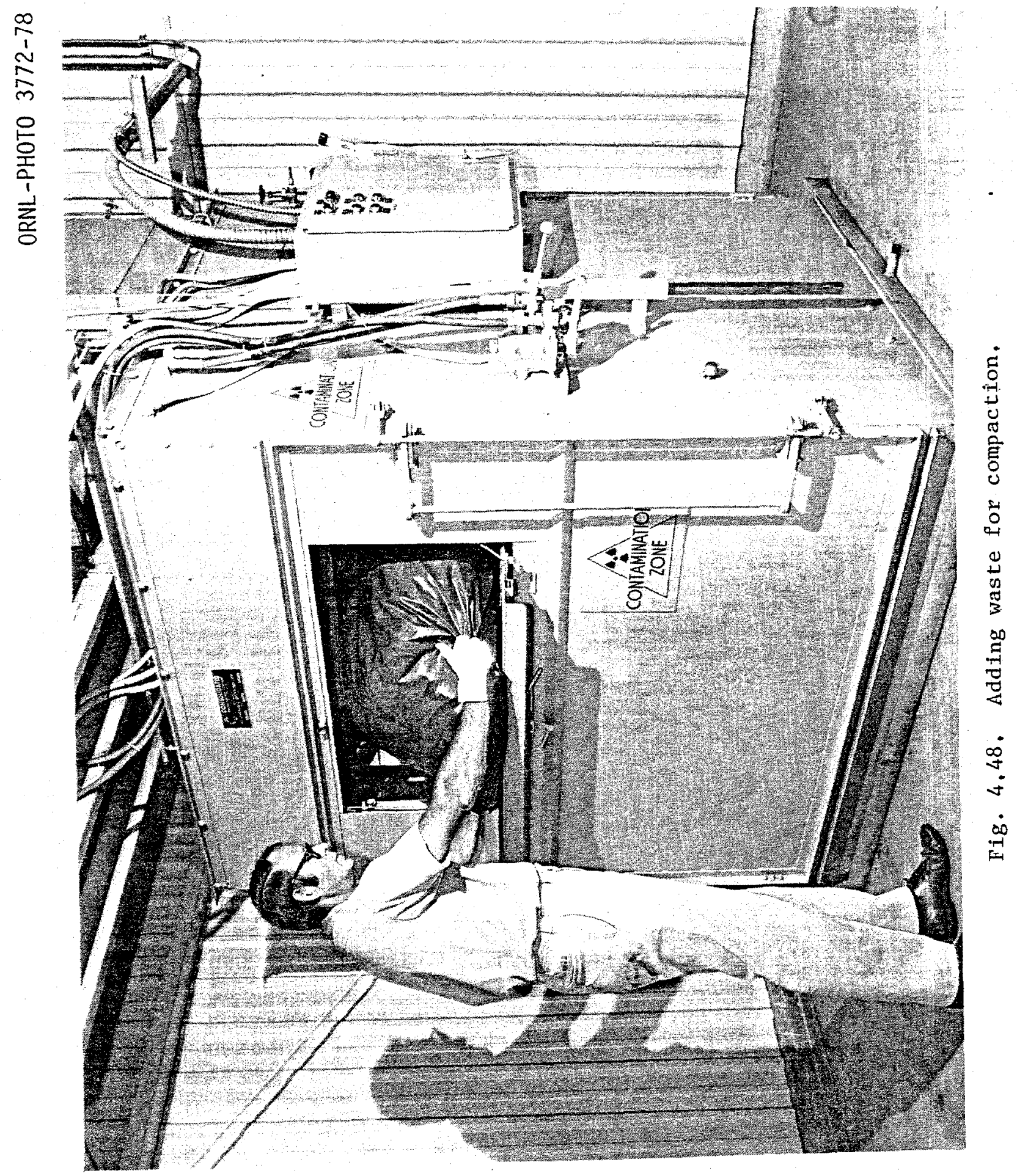



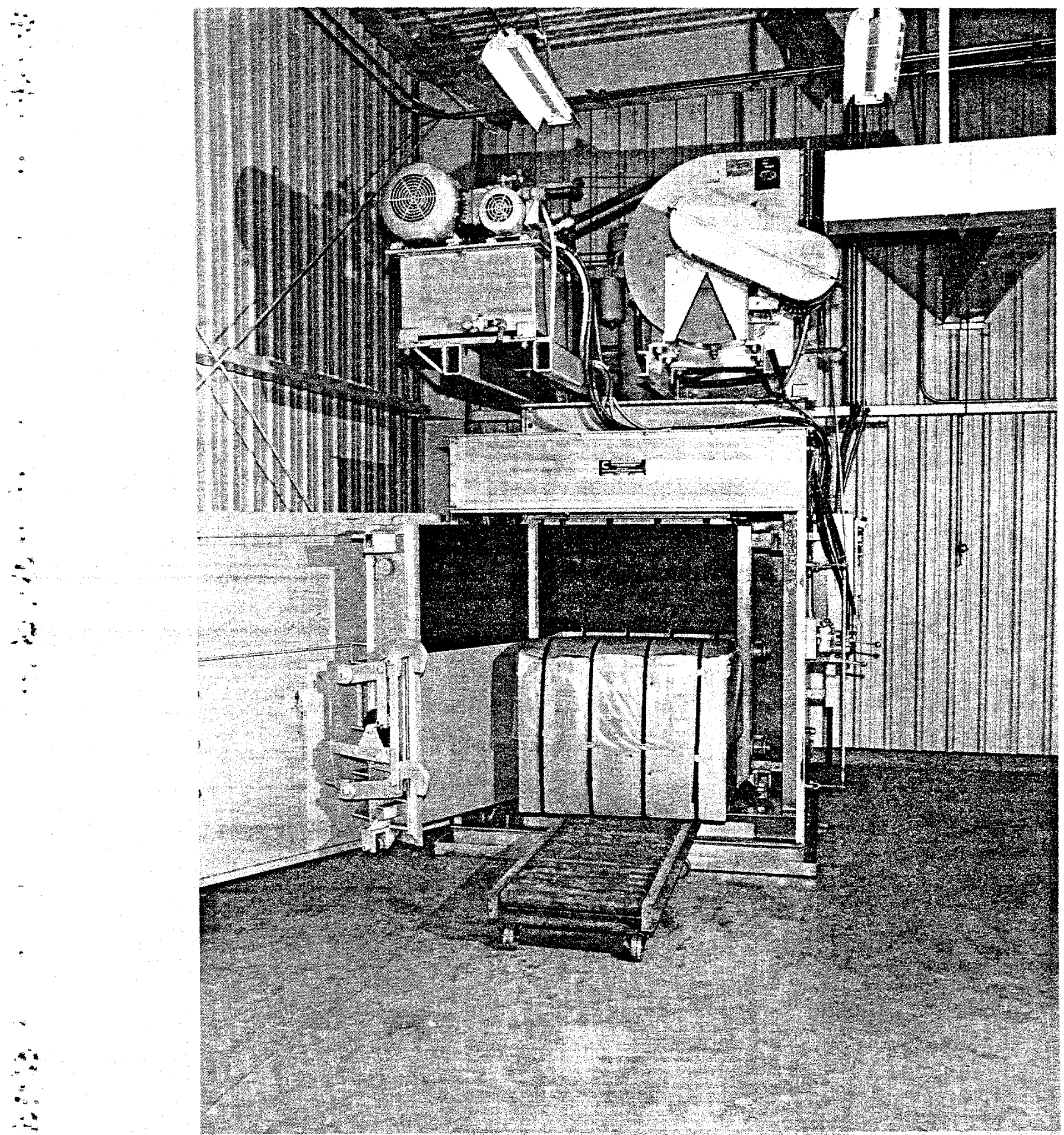

Fig. 4.49. Banded bale of compacted waste ready for removal. 


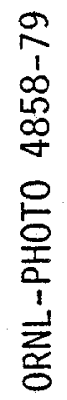

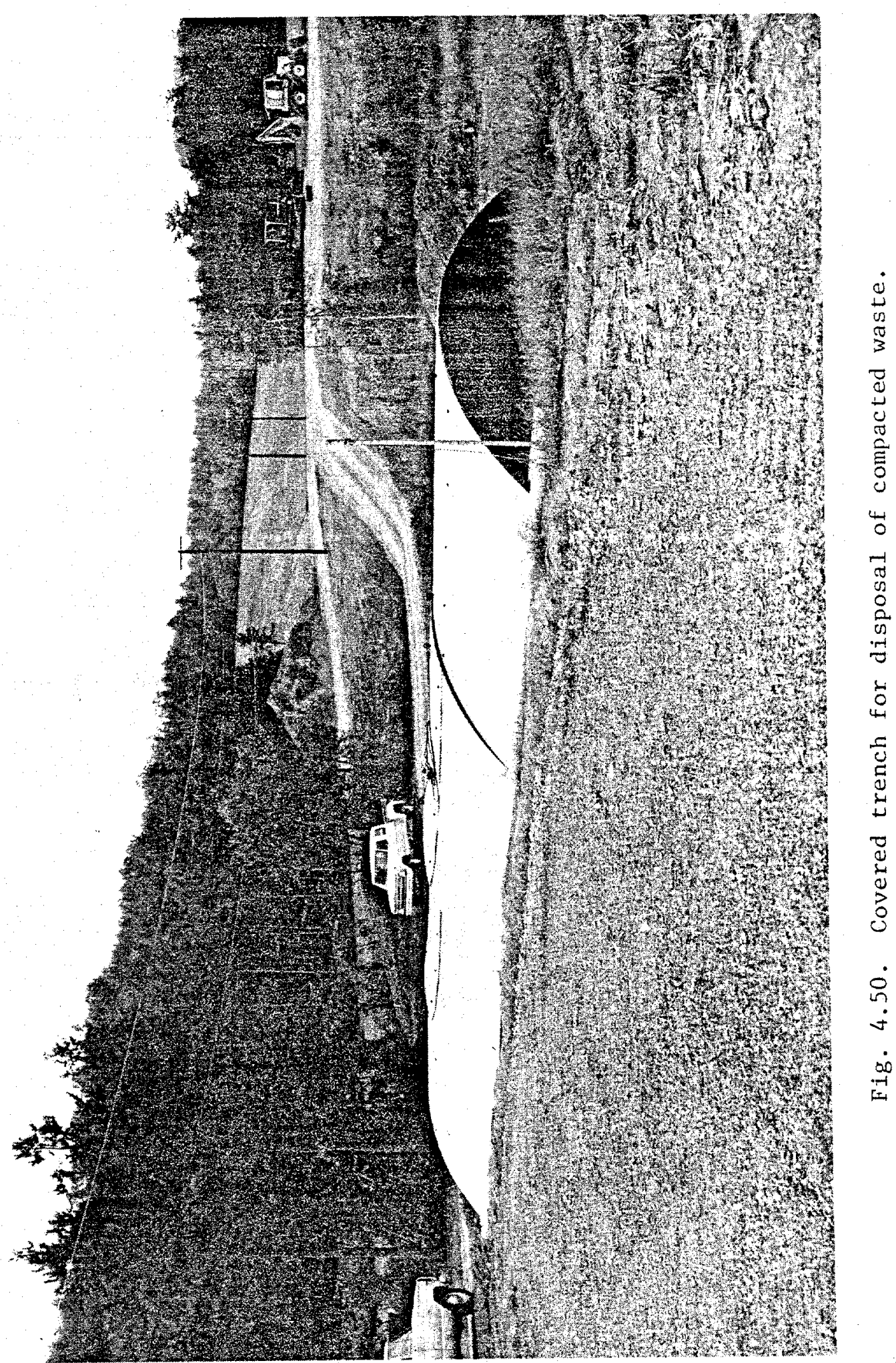




\subsubsection{Introduction}

To monitor the movement of radionuclides from the SWSAs, two systems are utilized. These are (1) a series of monitoring wells located in and around the SWSAs to provide groundwater samples and (2) a series of flow measurement and sampling devices in white Oak Creek and its tributaries known as the Streamflow Monitoring System. Data from these systems provide information regarding the retentive capabilities of the storage areas and also provide information regarding the total releases of radionuclides to the Clinch River to ensure conformance with effluent release requirements.

\subsubsection{Monitoring We11s}

Monitoring wells have been used with some degree of effectiveness for monitoring radionuclide movement in the ORNL SWSAs since 1950. Early wells were drilled primarily for the purpose of determining degree of contamination, hydrologic conditions, etc. Only recently have the wells been used for routine monitoring of radionuclide movement.

Most of the existing monitoring wells are simply shallow auger holes with uncapped, corrugated casings perforated throughout their length. Through several years of existence, many of these wells have been destroyed or have deteriorated to the point where they can no longer be found or are no longer useful for obtaining representative samples. Questions also arise as to whether samples taken from the uncapped perforated well casings are truly representative of groundwater movement or whether they may reflect infiltration of surface water into the well. The system has been improved through the addition of new wells strategically placed in optimum locations for monitoring of groundwater movement. All recent wells and those planned for the future are constructed using a $10 \mathrm{~cm}$ ( $4 \mathrm{in.)}$ diam PVC tube casing. Despite the inadequacies of the system, much useful information has 
been obtained from the monitoring wells to characterize radionuclide transport quantities and mechanisms within the SWSAs.

As of 1974 , a total of $12,60,30$, and 47 monitoring wells were present in and around SWSA $-3,-4,-5$, and -6 respectively. These wells are illustrated on Figs. 4.52, 4.53, 4.25, and 4.29 respectively. At the request of the ORNL Environmental Coordinator, a revised monitoring well design for the swsAs was developed early in 1981.16 The design utilized many of the existing wells plus the previously mentioned construction of several new wells. The current monitoring system consists of a total of 101 wells which are monitored routinely by Industrial Safety and Applied Health Physics Division personnel.

\subsubsection{Streamflow Monitoring System}

A network of monitoring stations (Fig. 4.54), known as the Streamflow Monitoring System, is utilized to monitor flow and radionuclide concentration of surface waters both within the Laboratory and at the point of release from the Laboratory Reservation to the Clinch River. The original system consisted of five stations. Station I is located a short distance below the now abandoned process waste setting basin and the Process Waste Treatment Plant and monitors the effluent discharge from the Plant. Station 2 is located a short distance upstream of Station 1 and the Waste Treatment Plant and provides a baseline for evaluating the data received from Station 1 . Stations 3 and 4 are located on White Oak Creek and Melton Branch, respectively, a short distance upstream of their confluence and provide information on the contaminant contribution from each valley. Station 5, located at White Oak Dam, collects data on the radionuclide content of water leaving white Oak Lake and serves as the final reporting station for surface water effluents before they leave Laboratory control and enter the Clinch River. 
ORNL DWG 74-9602

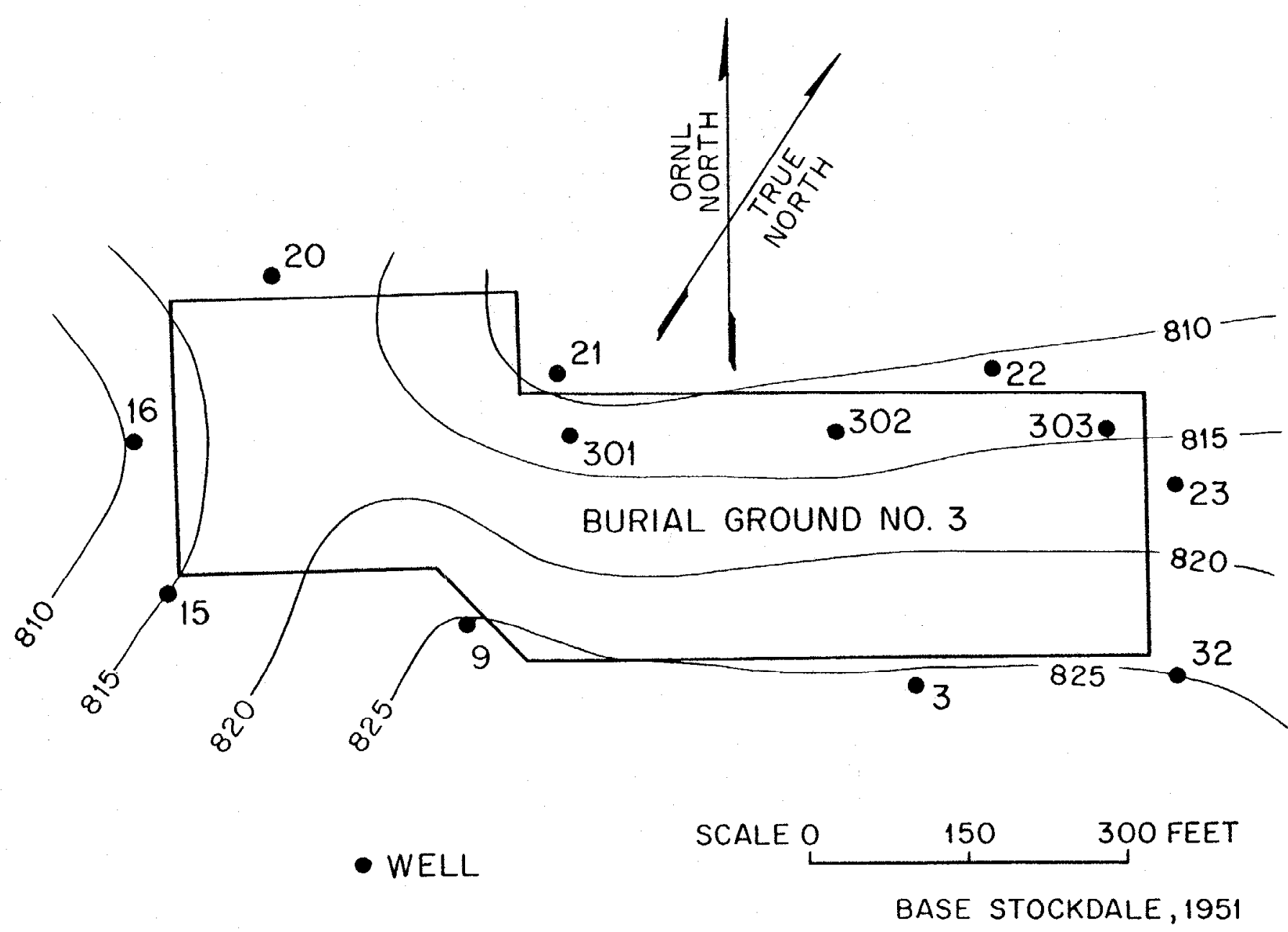

Fig. 4.52. Sketch of SWSA-3 showing groundwater contours and well locations. 


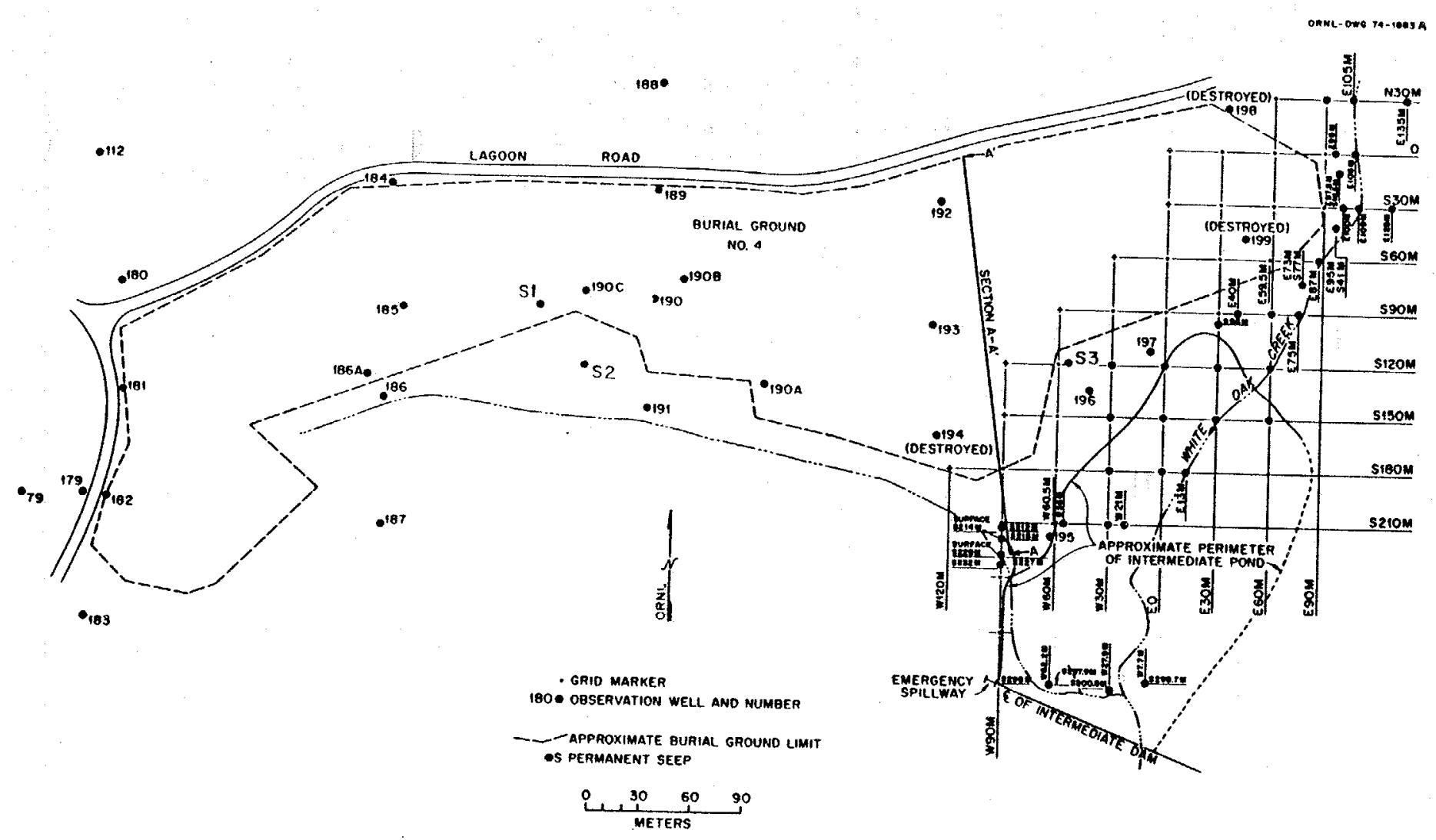

Fig. 4.53. Location of groundwater monitoring wells for SWSA-4. 


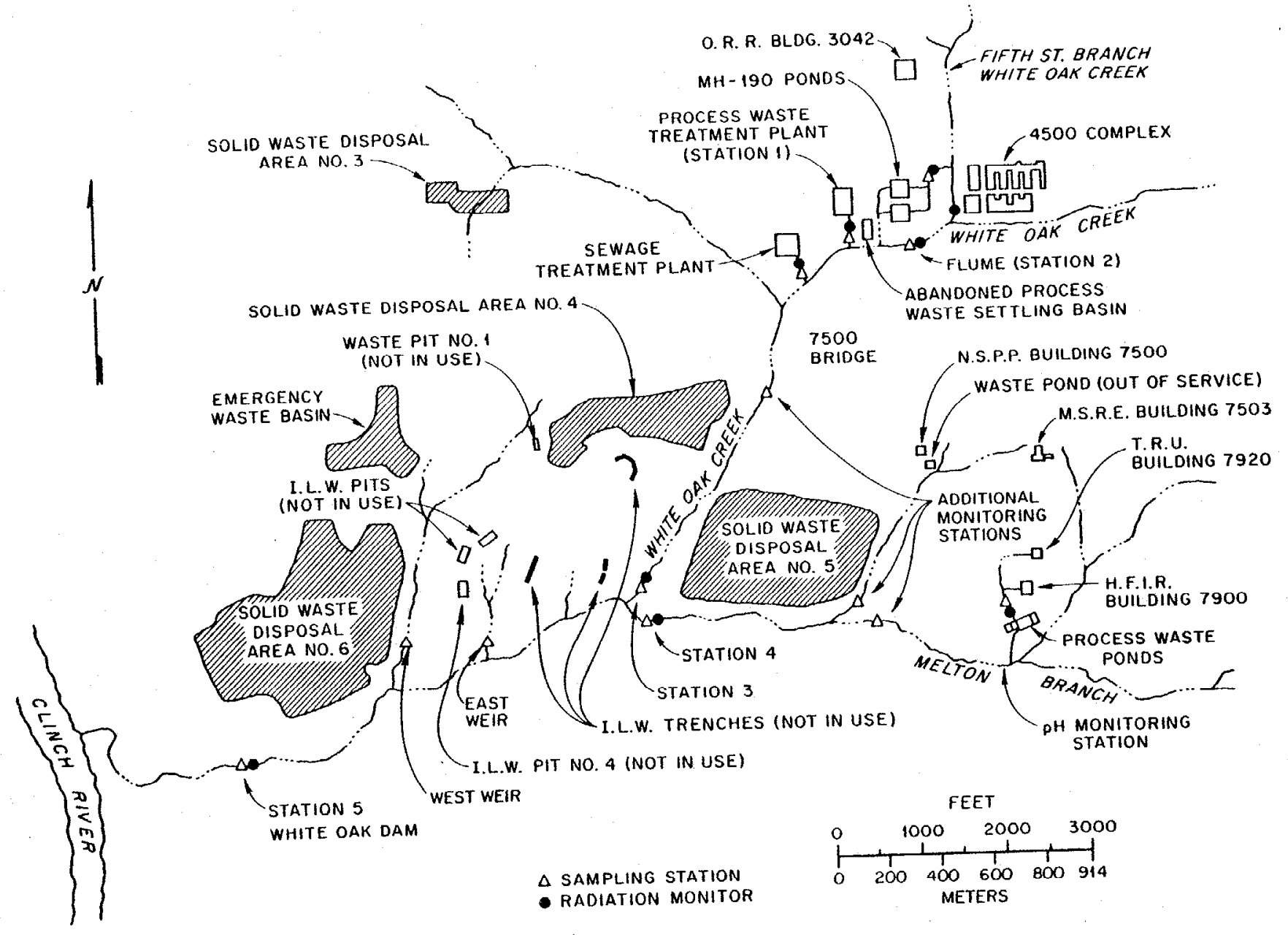

Fig. 4.54. Location plan for White Oak Creek sampling stations and radiation monitors. 
Stations 1 and 2 continuously monitor beta-gama activity in the streamflow. Flow-proportional samples are collected at Station 2 and composited for monthly analysis. At Stations 3 and 4 , discharge is measured by Cipolletti Weirs, and water is purned continuously through the system for counting of beta and gama activity and for proportional sampling. Dissolved oxygen, temperature, and $\mathrm{pH}$ are also monitored. Samples are collected at station 5 by a continuous proportional sampler also and are analyzed for gross activity and for specific isotopes as well as heavy metal content.

This system functioned very well for monitoring total effluent releases but was not adequate for identifying the source of these releases, in particular, releases from the SwSAs. To gain better definition of the radionuclide sources, five additional monitoring stations have been either constructed or reactivated. One of these additional stations is located on White Oak Creek between Stations 1 and 3 and upstream of SWSA-4 to provide additional information on releases from SWSA-4. The other two new stations are located near the southeast corner of SWSA-5 on Melton Branch and one of its tributaries to provide better definition of the effluents frou SWSA-5. Two other stations, the East Weir and West Weir, have recently been reactivated primaxily to determine radionuclide movement from the abandoned ILW pits and trenches. These stations are located on two tributaries of White Oak Creek between Stations 3 and 5. Flow proportional samples are collected at all these locations and provide a greater understanding of radionuclide movement within the White oak Creek Watershed.

One other deficiency in the system involves the inability of Stations 3, 4, and 5 to measure high flow sometimes encountered during periods of unusually high rainfall. This situation, occurring, on the average, two to three times per year, causes the weirs to overflow thus rendering them ineffective for measuring the streamflow and consequently making it impossible to obtain a flow proportional sample. A multimillion dollar project is currently under construction to rebuild stations 3, 4, and 5 and provide sufficient capacity for obtaining flow proportional samples under the maximum expected flow conditions. The new stations should be operational during FY-83. 


\subsection{SOLID WASTE STATISTICS}

Detailed records are kept of SWSA usage and are published quarterly in the "Solid Waste Storage Management Quarterly Report." In recent years the wastes have been segregated into transuranic, fissile, highlevel, etc.; and totals have been accumulated for individual categories. The following tables summarize information from the quarterly reports and other sources and provide data regarding the total waste volumes, curies, land usage, etc., through FY-81.

Table 4.5. Land used for solid waste disposal

\begin{tabular}{|c|c|c|c|c|c|c|}
\hline & \multicolumn{2}{|c|}{ Total (a11 SWSA) } & \multicolumn{2}{|c|}{ SWSA -5} & \multicolumn{2}{|c|}{ SWSA-6 } \\
\hline & meters ${ }^{2}$ & (acres) & meters ${ }^{2}$ & (acres) & meters ${ }^{2}$ & (acres) \\
\hline Prior to & & & & & & \\
\hline$F Y-82$ & $356,744^{a}$ & $(88.17)^{a}$ & $202,452^{\mathrm{a}}$ & $(50.04)^{a}$ & $30,466^{\mathrm{a}}$ & $(7.53)^{\mathrm{a}}$ \\
\hline FY 1981 & 1,875 & $(0.46)$ & 63 & $(0.02)$ & 1,510 & $(0.38)$ \\
\hline FY 1980 & 2,840 & $(0.70)$ & 3 & $(0.002)$ & 2,832 & $(0.70)$ \\
\hline FY 1979 & 3,277 & $(0.81)$ & 81 & $(0.02)$ & 3,196 & $(0.79)$ \\
\hline FY 1978 & 3,237 & $(0.80)$ & 81 & $(0.02)$ & 3,156 & $(0.78)$ \\
\hline FY 1977 & 3,196 & $(0.79)$ & 202 & $(0.05)$ & 2,994 & $(0.74)$ \\
\hline TQ $1976^{b}$ & 1,052 & $(0.26)$ & 41 & $(0.01)$ & 1,012 & $(0.25)$ \\
\hline FY 1976 & 4,046 & $(1.00)$ & 364 & $(0.09)$ & 3,582 & $(0.91)$ \\
\hline FY 1975 & 4,248 & $(1.05)$ & 41 & $(0.01)$ & 4,208 & $(1.04)$ \\
\hline
\end{tabular}

${ }^{a}$ Corrected to most recent civil engineering data.

${ }^{b}$ Third Quarter FY 1976 - see Note (A) Table 4.7. 
Table 4.6. Total radioactive waste in SWSAs

\begin{tabular}{|c|c|c|c|c|c|c|c|c|c|c|}
\hline & \multicolumn{2}{|c|}{ Volume } & \multicolumn{2}{|c|}{ General radwaste } & \multicolumn{2}{|c|}{ Landfill waste } & \multicolumn{2}{|c|}{ Transuranic } & \multicolumn{2}{|c|}{ Fissile waste } \\
\hline & $\mathrm{m}^{3}$ & $\left(\mathrm{ft}^{3}\right)$ & $\mathrm{m}^{3}$ & $\left(\mathrm{ft}^{3}\right)$ & $\mathrm{min}^{3}$ & $\left(\mathrm{ft}^{3}\right)$ & $\mathrm{m}^{3}$ & $\left(\mathrm{ft}^{3}\right)$ & $\mathrm{m}^{3}$ & $\left(\mathrm{ft}^{3}\right)$ \\
\hline Prior to FY-82 & $194,158.1$ & $(6,858,288)$ & $191,569 \cdot 2^{a}$ & $(6,766,840)^{a}$ & 499.4 & $(17,640)$ & $1,953.3$ & $(68,998)$ & 325.8 & $(11,508)$ \\
\hline FY $1981^{b}$ & $1,784.1$ & $(63,021)$ & $1,609 \cdot 3^{b}$ & $(56,845)$ & 111.9 & $(3,954)$ & 62.2 & $(2,200)$ & 0.4 & (12) \\
\hline FY 1980 & $2,343.4$ & $(82,775)$ & $2,046.1$ & $(72,275)$ & 230.3 & $(8,135)$ & 55.5 & $(1,961)$ & 2.7 & (96) \\
\hline FY 1979 & $2,109.0$ & $(74,496)$ & $1,917.3$ & $(67,726)$ & 116.0 & $(4,099)$ & 75.2 & $(2,658)$ & 0.4 & (13) \\
\hline FY 1978 & $2,384.5$ & $(84,228)$ & $2,265.6$ & $(80,028)$ & 41.1 & $(1,452)$ & 74.9 & $(2,647)$ & 2.9 & (101) \\
\hline FY 1977 & $2,223.3$ & $(78,534)$ & $2,133.1$ & $(75,348)$ & & & 84.5 & $(2,986)$ & 5.7 & $(200)$ \\
\hline TQ FY 1976 & 788.8 & $(27,862)$ & 714.8 & $(25,250)$ & & & 73.7 & $(2,604)$ & 0.2 & (8) \\
\hline FY 1976 & $2,788.5$ & $(98,498)$ & $2,643.5$ & $(93,376)$ & & & 141.5 & $(4,999)$ & 3.5 & (123) \\
\hline FY 1975 & $3,196.3$ & $(112,904)$ & $3,001.6$ & $(106,027)$ & & & 144.2 & $(5,093)$ & 50.5 & $(1,784)$ \\
\hline
\end{tabular}

$a_{\text {Includes }} 2.01 \mathrm{~m}^{3}$ (71 cu $\mathrm{ft}$ ) of retrievab1e $\beta-\gamma$ contaminated storage.

balues corrected to most recent calculations. 
Table 4.7. Total annual activity, volume, and weight of solid waste buried or stored

Fiscal year Activity (Ci) Volume $\left(\mathrm{ft}^{3}\right)$ Volume $\left(\mathrm{m}^{3}\right)$ Weight (1b) Weight (kg)

$\begin{array}{llllllll}43 & 2.0 \times 10^{3} & 2.5 \times 10^{4} & 700 & 3.0 \times 10^{5} & 1.4 \times 10^{5} \\ 44 & 2.0 \times 10^{3} & 2.5 \times 10^{4} & 700 & 3.0 \times 10^{5} & 1.4 \times 10^{5} \\ 45 & 2.0 \times 10^{3} & 2.5 \times 10^{4} & 700 & 3.0 \times 10^{5} & 1.4 \times 10^{5} \\ 46 & 2.0 \times 10^{3} & 2.5 \times 10^{4} & 700 & 3.0 \times 10^{5} & 1.4 \times 10^{5} \\ 47 & 1.0 \times 10^{4} & 1.4 \times 10^{5} & 3960 & 2.0 \times 10^{6} & 1.4 \times 10^{5} \\ 48 & 1.0 \times 10^{4} & 1.4 \times 10^{5} & 3960 & 2.0 \times 10^{6} & 1.4 \times 10^{5} \\ 49 & 1.0 \times 10^{4} & 1.4 \times 10^{5} & 3960 & 2.0 \times 10^{6} & 1.4 \times 10^{5} \\ 50 & 1.0 \times 10^{4} & 1.4 \times 10^{5} & 3960 & 2.0 \times 10^{6} & 1.4 \times 10^{5} \\ 51 & 1.0 \times 10^{4} & 1.4 \times 10^{5} & 3960 & 2.0 \times 10^{6} & 1.4 \times 10^{5} \\ 52 & 1.0 \times 10^{4} & 2.0 \times 10^{5} & 5660 & 2.0 \times 10^{6} & 1.4 \times 10^{5} \\ 53 & 1.0 \times 10^{4} & 2.0 \times 10^{5} & 5660 & 2.0 \times 10^{6} & 1.4 \times 10^{5} \\ 54 & 1.0 \times 10^{4} & 2.0 \times 10^{5} & 5660 & 2.0 \times 10^{6} & 1.4 \times 10^{5} \\ 55 & 1.0 \times 10^{4} & 2.0 \times 10^{5} & 5660 & 2.0 \times 10^{6} & 1.4 \times 10^{5} \\ 56 & 1.0 \times 10^{4} & 2.0 \times 10^{5} & 5660 & 2.0 \times 10^{6} & 1.4 \times 10^{5} \\ 57 & 2.0 \times 10^{4} & 2.0 \times 10^{4} & 9060 & 4.0 \times 10^{6} & 1.8 \times 10^{6} \\ 58 & 2.0 \times 10^{4} & 3.2 \times 10^{5} & 9060 & 4.0 \times 10^{6} & 1.8 \times 10^{6} \\ 59 & 2.0 \times 10^{4} & 3.2 \times 10^{5} & 9060 & 4.0 \times 10^{6} & 1.8 \times 10^{6} \\ 60 & 2.0 \times 10^{4} & 3.2 \times 10^{5} & 9060 & 4.0 \times 10^{6} & 1.8 \times 10^{6} \\ 61 & 4.0 \times 10^{4} & 5.31 \times 10^{5} & 15000 & 6.0 \times 10^{6} & 2.7 \times 10^{6} \\ 62 & 3.0 \times 10^{4} & 4.24 \times 10^{5} & 12000 & 5.0 \times 10^{6} & 2.3 \times 10^{6} \\ 66 & 2.0 \times 10^{4} & 3.33 \times 10^{5} & 9430 & 4.0 \times 10^{6} & 1.8 \times 10^{6} \\ 67 & 2.0 \times 10^{4} & 3.21 \times 10^{5} & 9090 & 4.0 \times 10^{6} & 1.8 \times 10^{6} \\ 64 & 1.0 \times 10^{4} & 1.89 \times 10^{5} & 5350 & 2.0 \times 10^{6} & 9.1 \times 10^{5} \\ 65 & 1.0 \times 10^{4} & 1.59 \times 10^{5} & 4500 & 2.0 \times 10^{6} & 9.1 \times 10^{5} \\ 56 & 1.0 \times 10^{4} & 1.99 \times 10^{5} & 5640 & 2.0 \times 10^{6} & 9.1 \times 10^{5}\end{array}$


Table 4.7. (continued)

Fiscal year Actlvity (Ci) Volume $\left(\mathrm{ft}^{3}\right)$ Volume $\left(\mathrm{m}^{3}\right)$ Weight (lb) Weight (kg)

$\begin{array}{llllllll}68 & 2.0 \times 10^{4} & 2.42 \times 10^{5} & 6850 & 3.0 \times 10^{6} & 1.4 \times 10^{6} \\ 69 & 1.0 & \times 10^{4} & 1.92 \times 10^{5} & 5440 & 2.0 \times 10^{6} & 9.1 \times 10^{5} \\ 70 & 1.0 \times 10^{4} & 1.28 \times 10^{5} & 3630 & 1.0 \times 10^{6} & 4.5 \times 10^{5} \\ 71 & 1.1 \times 10^{4} & 1.67 \times 10^{5} & 4730 & 2.29 \times 10^{6} & 1.0 \times 10^{6} \\ 72 & 1.0 \times 10^{4} & 1.29 \times 10^{5} & 3650 & 1.90 \times 10^{6} & 8.6 \times 10^{5} \\ 73 & 9.0 \times 10^{3} & 1.07 \times 10^{5} & 3030 & 1.57 \times 10^{6} & 7.1 \times 10^{5} \\ 74 & 8.8 \times 10^{3} & 1.20 \times 10^{5} & 3400 & 1.55 \times 10^{6} & 7.0 \times 10^{5} \\ 75 & 2.0 \times 10^{3} & 1.12 \times 10^{5} & 3170 & 1.41 \times 10^{6} & 6.4 \times 10^{5} \\ 76(\mathrm{~A}) & 1.1 \times 10^{4} & 1.25 \times 10^{5} & 3540 & 1.49 \times 10^{6} & 6.8 \times 10^{5} \\ 77 & 2.0 \times 10^{4} & 7.77 \times 10^{5} & 2200 & 6.37 \times 10^{5} & 1.7 \times 10^{5} \\ 78 & 5.25 \times 10^{3} & 8.32 \times 10^{5} & 2360 & 9.24 \times 10^{5} & 4.2 \times 10^{5} \\ 79 & 5.55 \times 10^{4} & 7.45 \times 10^{4} & 2110 & 1.34 \times 10^{6} & 6.1 \times 10^{5} \\ 80 & 6.32 \times 10^{4} & 8.29 \times 10^{4} & 2350 & 1.31 \times 10^{6} & 6.0 \times 10^{5} \\ 81 & 1.16 \times 10^{5} & 6.37 \times 10^{4} & 1800 & 1.68 \times 10^{6} & 7.6 \times 10^{5}\end{array}$

(A) July 1, 1975 through September 30, 1976 - Reflects change in fiscal year to begin in October. 
Table 4.8. High-radiation level alpha wastes in retrievable storage below grade storage - Buildings 7827 and 7855 and trenches

\begin{tabular}{|c|c|c|c|c|c|c|}
\hline & \multicolumn{2}{|c|}{ Tota1 volume } & \multirow{2}{*}{$\frac{\text { Transuranium } \&{ }^{233} \mathrm{U}}{(\mathrm{g})}$} & \multicolumn{2}{|c|}{ Volume in Ss liners ${ }^{c}$} & \multirow{2}{*}{ Number of casks } \\
\hline & $\mathrm{m}^{3}$ & $\left(f t^{3}\right)$ & & $\mathrm{m}^{3}$ & $\left(f t^{3}\right)$ & \\
\hline Prior to $\mathrm{FY}-82$ & 586.6 & $(20,716)$ & $4,049^{a}$ & 3.7 & 130 & 202 \\
\hline FY 1981 & 25.5 & $(900)$ & 0 & 0 & $(0)$ & 9 \\
\hline FY 1980 & 25.5 & $(900)$ & 0 & 0 & $(0)$ & 7 \\
\hline FY 1979 & 42.5 & $(1,502)$ & 9 & 0.01 & (2) & 15 \\
\hline FY 1978 & 40.9 & $(1,443)$ & 151 & 0.8 & $(27)$ & 14 \\
\hline FY 1977 & 69.0 & $(2,438)$ & 565 & 1.1 & $(38)$ & 24 \\
\hline TQ FY 1976 & 22.9 & (808) & 34 & 0.2 & $(8)$ & 8 \\
\hline FY 1976 & 45.3 & $(1,601)$ & 168 & 0.9 & $(31)$ & 15 \\
\hline FY 1975 & 70.8 & $(2,500)$ & 15 & $\mathrm{NA}$ & NA & 25 \\
\hline FY 1974 & 82.2 & $(2,905)$ & 140 & NA & NA & 29 \\
\hline FY 1973 & 124.6 & $(4,400)$ & $889^{a}$ & NA & NA & 44 \\
\hline FY 1972 & 34.0 & $(1,200)$ & $2,066^{a}$ & NA & $\mathrm{NA}$ & $12^{b}$ \\
\hline FY 1971 & 2.8 & $(100)$ & $12^{a}$ & NA & $\mathrm{NA}$ & $a^{b}$ \\
\hline
\end{tabular}

${ }^{\mathrm{a}}$ Quantities of isotopes present were most often given as less than the maximum quantity approved for the specific container used; best estimates are now required.

${ }^{b}$ Forty-three casks for FY-71 and 44 casks for FY-72 are buried nonretrievably.

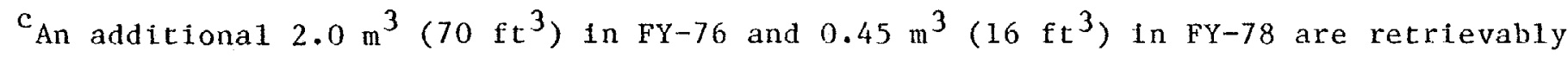
stored. 
Table 4.9. Low-level alpha wastes in retrievable storage Buildings 7826 and 7834

\begin{tabular}{|c|c|c|c|c|}
\hline & \multicolumn{2}{|c|}{ Volume } & \multirow{2}{*}{$\begin{array}{l}\text { Transuranium } \\
\text { and } 233_{\mathrm{U}}(\mathrm{g})\end{array}$} & \multirow{2}{*}{$\begin{array}{c}\text { Number of } \\
\text { stainless steel } \\
\text { drums }\end{array}$} \\
\hline & $\mathrm{m}^{3}$ & $\left(f t^{3}\right)$ & & \\
\hline Prior to $\mathrm{FY}-82$ & 404.4 & $(14,283)$ & 12,326 & $1504^{b}$ \\
\hline FY 1981 & 35.4 & $(1,220)$ & 814 & 129 \\
\hline FY 1980 & 30.0 & $(1,061)$ & 335 & 133 \\
\hline EY 1979 & 32.7 & $(1,156)$ & 818 & 145 \\
\hline FY 1978 & 34.1 & $(1,204)$ & 585 & 151 \\
\hline FY 1977 & 15.5 & $(548)$ & 1,294 & 69 \\
\hline TQ FY 1976 & 12.9 & $(456)$ & 1,053 & 57 \\
\hline FY 1976 & $46 \cdot 3^{a}$ & $(1,634)$ & 2,352 & 205 \\
\hline FY 1975 & $42.1^{a}$ & $(1,488)$ & 1,761 & 190 \\
\hline FY 1974 & $30.7^{a}$ & $(1,086)$ & 1,176 & 137 \\
\hline
\end{tabular}


Table 4.10. Fissile waste in SWSAs

\begin{tabular}{|c|c|c|c|c|c|}
\hline \multirow[b]{2}{*}{. } & \multicolumn{2}{|c|}{ Volume } & \multirow{2}{*}{$\begin{array}{l}\text { Fissile } \\
\text { isotopes (g) }\end{array}$} & \multirow{2}{*}{$\begin{array}{l}\text { Number of } \\
\text { auger holes }\end{array}$} & \multirow{2}{*}{$\begin{array}{l}\text { Number of } \\
\text { trenches }\end{array}$} \\
\hline & $\mathrm{m}^{3}$ & $\left(f t^{3}\right)$ & & & \\
\hline Prior to FY-82 & 325.4 & $(11,494)$ & 22,833 & 222 & 8 \\
\hline FY 1981 & 0.4 & (12) & 210 & 3 & 0 \\
\hline FY 1980 & 2.7 & $(60)$ & 953 & 3 & 0 \\
\hline FY 1979 & 0.4 & (13) & 39 & 2 & 0 \\
\hline EY 1978 & 2.5 & $(87)$ & 1,261 & 14 & 0 \\
\hline FY 1977 & 5.7 & $(200)$ & 1,728 & 8 & 0 \\
\hline TQ EY 1976 & 0.2 & (8) & 2 & 1 & 0 \\
\hline FY 1976 & 3.5 & $(123)$ & 1,225 & 6 & 1 \\
\hline FY 1975 & 50.5 & $(1,784)$ & 1,992 & 7 & 4 \\
\hline FY 1974 & 58.9 & $(2,082)$ & 1,915 & 9 & 1 \\
\hline FY 1973 & 33.8 & $(1,195)$ & 2,128 & 40 & 0 \\
\hline FY 1972 & 101.2 & $(3,576)$ & 7,289 & 76 & 1 \\
\hline FY $1971^{\mathrm{a}}$ & 48.3 & $(1,705)$ & 2,784 & 36 & 1 \\
\hline FY $1970^{b}$ & 17.4 & $(613)$ & 1,302 & 16 & 0 \\
\hline
\end{tabular}

Transuranium Naste Storage Facllity initiated October 1970.

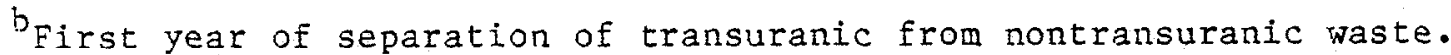
Prior to this, wastes containing isotopes ${ }^{233} \mathrm{U},{ }^{235} \mathrm{U}$, and ${ }^{239} \mathrm{Pu}$ were placed below grade in the same section, SWSA-5. 


\subsection{REFERENCES}

1. F. T. Binford and J. R. Gisse1, A Description and Safety Analysis of Solid Radioactive Waste Storage Facilities and Procedures at the Oak Ridge National Laboratory, ORNL/CF/75-2-23, March 1975.

2. J. 0. Duguid, et al., A Study of Low-Level Radioactive Solid Waste Disposal and Storage Areas at the Oak Ridge National Laboratory, ORNL/CF-77/376, Augist 1977 .

3. Operations Division, ORNL, Radioactive Solid Waste Operations Manual, current revision.

4. Nuclear Fuel and Waste Programs, ORNL, ORNL Waste Management Operations Annual Progress Report for Period Ending September 30, 1979, ORNL/NFW-79/72, November 1979.

5. Operations Division, ORNL, Solid Waste Storage Management Quarterly Report - First Quarter FY 1980 - October-December 1979, ORNL/CF-80/29, January 1980 , et al.

6. D. A. Webster, A Review of Hydrologic and Geologic Conditions Related to the Radioactive Solid-Waste Burial Grounds at Oak Ridge National Laboratory, Tennessee, U.S. Geologic Survey open file report 76-727, 1976 .

7. K. E. Cowser, T. F. Lomenick, and W. M. McMaster, Status Report on Evaluation of Solid Waste Disposal at ORNL: I, ORNL-3035, February 1961.

8. T. F. Lomenick and K. E. Cowser, Status Report on Evaluation of Solid Waste Disposal at ORNL: II, ORNL-3182, December 1961.

9. T. W. Oakes and K. E. Shank, Subsurface Investigation of the Energy Systems Research Laboratory Site at Oak Ridge National Laboratory, ORNL/TM-5695, July 1977.

10. J. R. Gissel, A Description and Safety Analysis Report of the Radioactive Solid waste Compactor Facility, Building 7831, ORNL/CF-78/242, July 1978.

11. Gilbert/Commonwealth, Programmatic Assessment of Radioactive Waste Management, ORNL/Sub-80/13837/3, June 1980 .

12. J. R. Gisse1, Proposed Monitoring Well System for ORNL Radioactive Solid Waste Storage Areas, ORNL/NFW-79/33, May 1979.

13. J. 0. Duguid, Status Report on Radioactivity Movement from Burial Grounds in Melton and Bethel Valleys, ORNL-5017, Environmental Sciences Division Publication No. 658 , July 1975. 
14. Dames \& Moore, Applicability of a Generic Monitoring Program for Radioactive Waste Burial Grounds at Oak Ridge National Laboratory and Idaho National Engineering Laboratory, ORNL/Sub-7167/1, July 1978.

15. Oak Ridge National Laboratory, Health Physics Procedure Manual, current revision.

16. J. Switek, ORNL Ground Water Monitoring, ORNL/NFW-31/1, Apri1 1981. 


\section{ACCIDENT ANALYSIS}

This section describes and discusses accident situations which could conceivably occur with respect to SWSA operation and evaluates their consequences. For ease in understanding, the discussion is grouped in terms of impact of normal operations, accidents related to buried (nonretrievable) waste, accidents related to stored (retrievable) waste, and accidents related to the waste Compactor Facllity. This grouping allows for an orderly discussion of all reasonable accident situations without addressing each of the numerous types of waste in the SWSAs.

This discussion is restricted primarily to the short-term safety considerations of SWSA operation and does not consider long-term occurrences such as are frequently considered in waste imobilization and disposal studies. This allows elimination from consideration of such events as meteorite strikes, long-term unchecked erosion, reclamation, and loss of institutional control which either have extremely low probabilities of occurrence in the near future or are beyond the scope of this study. In general, this study restricts itself to the day-to-day operational safety of the storage areas with consijeration for any health or safety hazards resulting from the collection handing, disposal and short-term physical containment of radioactive solid waste; but it does not address the question of long-term disposal and inmobilization of the material through its hazardous lifetime. This is the subject of another field of endeavor and is beyond the scope of this report.

\subsection{RADIOLOGICAL IMPACT OF NORMAL OPERATIONS}

All normal SWSA operations are conducted in a manner such that their radiological impact to personnel and the environment is minimal. A major portion of the solid waste collected and disposed of in the ORNL SWSAs is low-level waste which requires no special shielding considerations for handing and disposal. The waste is packaged by the 
generator in appropriate containers. This packaging minimizes the possibility of spreading the contamination during transport, handling, and disposal operations. Most low-level waste is transported and disposed of utilizing the dumpster in which the waste is accumulated resulting in minimal interaction between SWSA personnel and the waste. Handling of higher level waste is accomplished in accordance with the ORNL Health Physics Procedure Manual. Health Physics Procedure 3.6 requires a Radiation Work Permit when the expected dose is greater than 20 mren to the body or 300 mren to extremities during a regular work shift; when the dose rate is greater than $5 \mathrm{rem} / \mathrm{h}$ (total body); when airborne radioactivity is greater than the established MPC for a 40-h week; or when otherwise specified or required by established rules or procedure. The Radiation Work Permit is authorized by the nember of supervision responsible for the work being done and must be certified by a representative of Industrial Safety and Applied Health Physics. The permit describes the job, the location, contains information concerning the type and nagnitude of radiation hazard involved, and specifies the precautions and necessary protective equipment and monitoring instruments required.

Special approvals and possibly committee reviews are required when radiation or contamination levels exceed specified limits in Procedure 3.5 of the Health Physics Procedure Manual. All personnel involved in waste storage operations are required to wear personal dosimeters and pocket meters in addition to the normal badge dosimeter. These dosimeters and pocket meters are monitored by Health Physics personnel in accordance with the Health Physics Procedure Manual.

Solid waste disposal operations is somewhat unique in that it involves controlled releases of radioactivity to the environment through burial of the radioactive waste. With the exception of the retrievably stored transuranic waste, little attempt is made to permanently isolate the radionuclides from the soil in which they are deposited. Instead, the soil itself acts as the primary containment for the radionuclides. Although releases do occur, numerous years of disposal and monitoring 
has indicated that the ORNL SWSAs present no significant hazard to the environment or public population outside the Laboratory.

The monitoring and reporting of radionuclide seepage from the SWSAs are handied primarily by the Laboratory's Environmental Sciences Division and Environmental Coordinator's Office which periodically reports the release data. The magnitude of the problem can adequately be illustrated by Tables 5.1 and 5.2 which present the total ${ }^{90} \mathrm{Sr}$ discharge, the primary radionuclide of concern, from SWSA-4 and SWSA-5 respectively. This data was determined through analysis of proportional samples at various points in the Stream Flow Monitoring System. By sampling at different stations and observing the differences, the contribution from specific areas can be determined. To place these values in perspective it is necessary to look at the concentration of ${ }^{90} \mathrm{Sr}$ in the Clinch River just outside the reservation boundaries. The most restrictive MPC value given in DOE order 5480.1A, Chapter XI (ERDAM-0524) for ${ }^{90} \mathrm{Sr}$ in water is $3 \times 10^{-7} \mu \mathrm{Ci} / \mathrm{ml}$. With an average Clinch River flow of $133 \mathrm{~m}^{3} / \mathrm{s}$, an annual average release of over 12 curies yer year would be required to exceed an annual average of 1 percent of the above MPC in the Clinch River. Even the largest discharges in Tables 5.1 and 5.2 are less than half this amount.

All reasonable measures are taken to reduce these seepage releases from the SWSAs as much as possible. Land surface erosion is controlled through seeding with grass when an area is closed. Trees and underbrush that might send roots into a closed trench are removed and the areas are fenced and appropriately identified as hazardous waste storage areas. Paved conductor ditches have been installed in several areas of the storage areas to serve as runoff diversion systems and improve the surface drainage of the areas. Near-surface seals have been used in special problem areas to reduce seepage. One sealing method involves stripping away the overburden from the area, sealing with a PVC membrane and then 
Table 5.1. Discharge of ${ }^{90} \mathrm{Sr}$ from SWSA-4 and precipitation data for water - years 1963 through 1977

\begin{tabular}{|c|c|c|c|}
\hline $\begin{array}{l}\text { Water } \\
\text { year }\end{array}$ & $\begin{array}{l}\text { Precipitation } \\
\text { (cm) }\end{array}$ & $\begin{array}{c}\text { Total }{ }^{90} \mathrm{Sr} \\
\text { discharge } \\
\text { (Ci) }\end{array}$ & $\begin{array}{r}\text { Discharge } \\
\text { of } 90 \mathrm{Sr} \\
(\mathrm{mCi} / \mathrm{cm}) \\
\end{array}$ \\
\hline 1963 & 140.5 & 4.82 & 34.3 \\
\hline 1964 & 106.9 & 2.98 & 27.9 \\
\hline 1965 & 132.0 & 3.10 & 23.5 \\
\hline 1966 & 103.8 & 2.52 & $24 \cdot 3$ \\
\hline 1967 & 153.8 & 2.72 & 17.7 \\
\hline 1968 & 114.3 & 2.04 & 17.8 \\
\hline 1969 & 101.8 & 2.08 & 20.4 \\
\hline 1970 & 121.7 & 1.60 & $13 \cdot 1$ \\
\hline 1971 & 122.6 & 1.18 & 9.6 \\
\hline 1972 & 120.4 & 2.36 & 19.6 \\
\hline 1973 & 181.0 & 1.58 & 8.7 \\
\hline 1974 & 174.7 & 5.22 & 29.9 \\
\hline 1975 & 146.6 & 3.22 & 21.9 \\
\hline 1976 & 123.9 & 5.12 & 41.3 \\
\hline 1977 & 129.1 & 2.27 & 17.6 \\
\hline
\end{tabular}

${ }^{a}$ Water year is September 1 through August 31 . 
Table 5.2. Discharge of ${ }^{90} \mathrm{Sr}$ from SWSA-5 and precipitation data for water - years 1967 through 1977

\begin{tabular}{|c|c|c|c|}
\hline $\begin{array}{l}\text { Water } \\
\text { year }\end{array}$ & $\begin{array}{c}\text { Precipitation } \\
(\mathrm{cm})\end{array}$ & $\begin{array}{c}\text { Total }{ }^{90} \mathrm{Sr} \\
\text { discharge } \\
\text { (Ci) }\end{array}$ & $\begin{array}{r}\text { Discharge } \\
\text { of }{ }^{90} \mathrm{Sr} \\
(\mathrm{mCi} / \mathrm{cm}) \\
\end{array}$ \\
\hline 1967 & 153.8 & 0.89 & 5.8 \\
\hline 1968 & 114.3 & 2.84 & 24.8 \\
\hline 1969 & 101.8 & 0.88 & 8.7 \\
\hline 1970 & 121.7 & 0.93 & 7.6 \\
\hline 1971 & 122.6 & 0.58 & 4.7 \\
\hline 1972 & 120.4 & 0.81 & 6.7 \\
\hline 1973 & 181.0 & 1.43 & 7.9 \\
\hline 1974 & 174.7 & 1.39 & 7.9 \\
\hline 1975 & 146.6 & 2.07 & 14.1 \\
\hline 1976 & 123.9 & 0.75 & 5.8 \\
\hline 1977 & 129.1 & 0.43 & 3.4 \\
\hline
\end{tabular}


replacing the overburden and reseeding. Figure 5.1 illustrates a nearsurface seal in SWSA-5. In this instance, two concrete trench dams were also installed to compartmentalize the trench and retard groundwater inovement. A second method of surface sealing, illustrated in Fig. 5.2, involves installation of a bentonite-shale mixture in a manner similar to the PVC seal. Surface contouring is also used to divert runoff away from problem areas.

Improvements such as those above are being made and evaluated on a continuing basis to ensure maximum achievable confinement of the radionuclides in the storage areas.

\subsection{BURIED WASTE ACCIDENTS}

\subsubsection{Releases During Transport and Disposal}

The potential for release of radioactive material during transport of solid waste to the storage areas has been minimized. The requirements for packaging ensure that the waste is capable of being transported to the storage area and disposed of without undue personnel exposures or any releases of radioactive material under normal conditions. Low-level wastes are packaged in plastic bags or bucket type waste containers and then placed in the low-level dumpsters. High-level material is placed in an appropriate shielded container before being turned over to SWSA personnel for transport and disposal. Existing procedures adequately define transportation, 10 testing of equipment, 4 Health Physics considerations, ${ }^{3}$ responsibilities, ${ }^{2}$ and procedures to follow in the event of an accident during transport of a shielded carrier. ${ }^{3,5}$ Transportation of all radioactive waste to the storage areas is accomplished on ORNL Iimited access roads thus minimizing any exposures to the general public as a result of a transportation accident. Buried waste, by definition, contains less than $10 \mathrm{nCi} / \mathrm{g}$ of transuranics; and thus, exposure to, ingestion, or inhalation of long-lived alpha emitters is not a major consideration. 


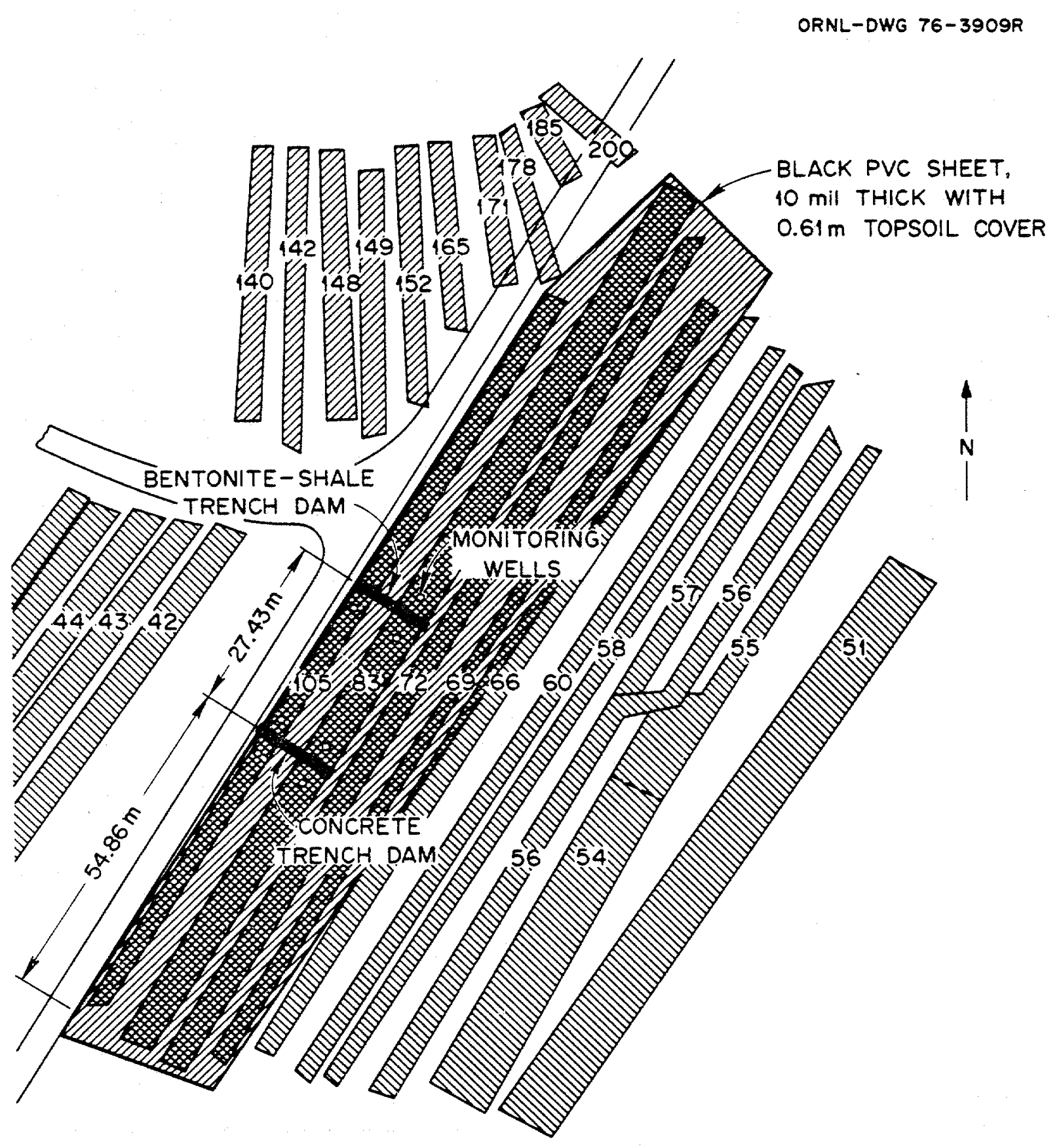

Fig. 5.1. Near-surface sealing of trenches in SWSA-5. 
ORNL-DWG $78-2159$

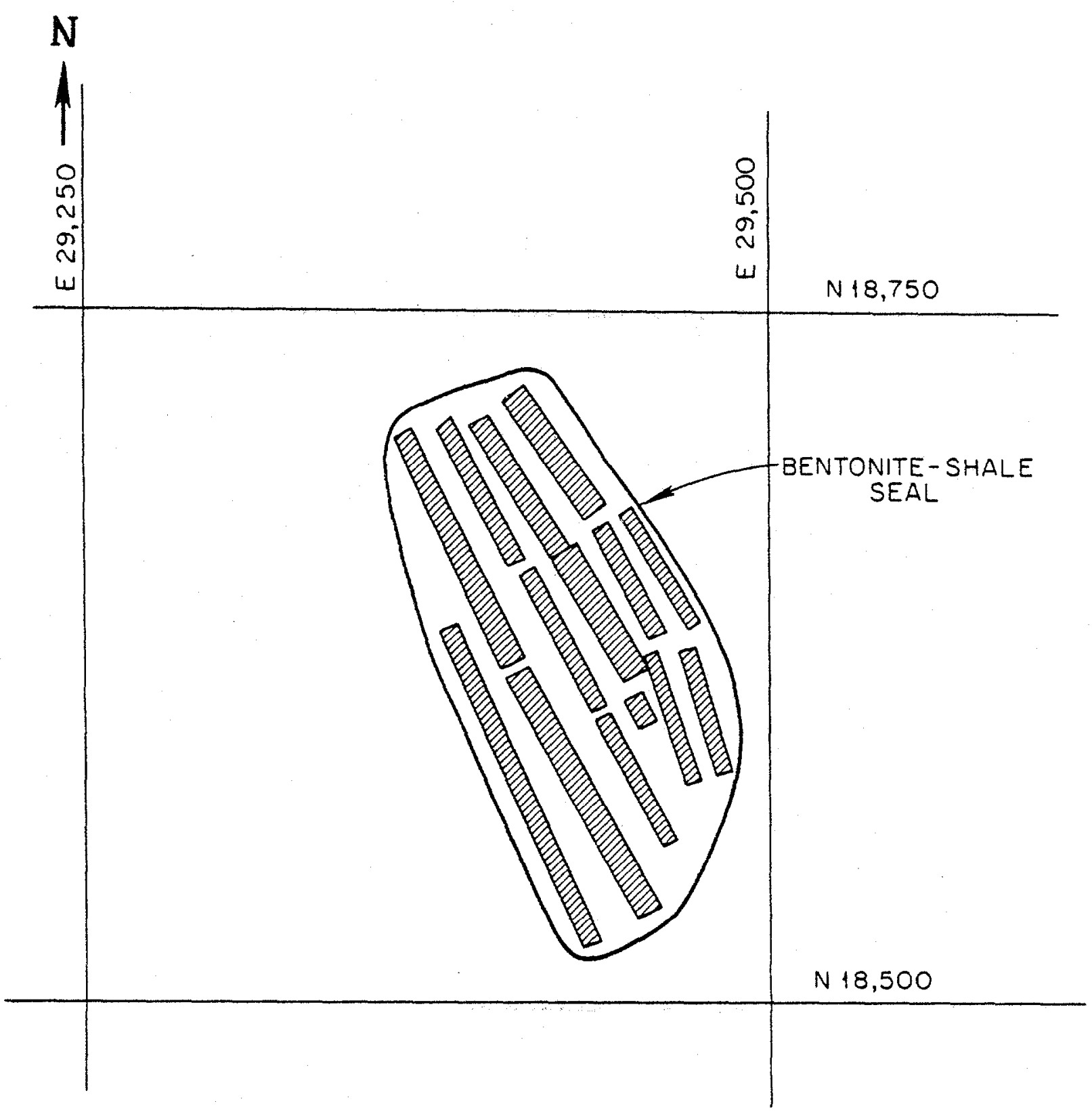

Fig. 5.2. Bentonite-shale surface seal in SWSA-5. 
Operating experience has demonstrated that little probability exists for a major release as a result of solid waste transportation and disposal operations. However, situations can be postulated where this could occur. A shielded cask could be dropped while being loaded or unloaded from the transport vehicle or could fall from the vehicle while in route to the storage area. The worst case would be for the cask to fall to the ground opening one door and exposing the inner container. The cask construction is such that no significant damage would occur to the cask in such a fall; and thus, the inner container would remain intact. Although the door is assumed to open, this is also somewhat improbable due to a safety latch on the door. With the inner container intact, there would be no significant spread of contamination from the cask but a radiation field would exist in the vicinity of the open end of the cask. The magnitude of this field would vary tremendously depending on the specific material in the cask. The area would be evacuated until Health Physics personnel had determined the extent of the problem, at which point neasures would be taken to close the cask or shield it in some appropriate manner.

A low-level waste dumpster could also be dropped during transport causing it to open and spill its contents. Since the waste is packaged before being placed in a dumpster, some contalnment of the waste would likely remain. The waste which is not contained would be spread around the area of the accident. Again, the first step would be to evacuate the area until Health Physics personnel are notified and have evaluated the situation. Since all low-level waste exhibits radiation levels less than $200 \mathrm{mrem} / \mathrm{h}$ at the surface of the container, radiation exposures would not be a major problem. Access to the area would be restricted until the spilled material could be cleaned up and the area surveyed and decontaminated as necessary.

The major result of either of the above situations would be lost time and expense for cleanup. Little environmental or personal injury would result. Speed limits within the Laboratory ensure that little probability exists for accidents involving high velocity impacts of elther dumpters or shielded casks. 


\subsubsection{Natural Phenomena}

The effects of natural phenomena on buried waste are minimal as the wastes are stored below grade. Tornados and other high winds would create little or no potential for an accident situation due to the minimum 3 ft of overburden in each waste trench. Floods also would have little influence on buried waste. As illustrated in Fig. 3.20, most of the SWSAs are outside of even the maximum probable flood plain. A small area of SWSA-6 and SWSA-1 would be covered during the maximum probable flood; however, this would do little more than temporarily increase the radionuclide transport in the trenches due to the excess groundwater. It is not probable that there would be enough sediment transport to remove the $3 \mathrm{ft}$ cover from a trench and expose or remove the waste.

A tornado could create a significant hazard in the event a tornado funnel were to pass directly over an open trench which contained waste but had not been backfilled. In this event, the waste could be scattered over a considerable area and would be difficult to clean up. Reference to Section 3, however, indicates a very low probability for a tornado on the reservation and this is not considered to be a significant risk.

An earthquake in the vicinity of the Laboratory could create an accident situation by opening a fissure through one or more trenches in one of the SWSAs and possibly exposing the waste in the trench. Some scattering of the material would probably occur locally. This situation would present a clean-up problem requiring radiation survey and removal of contaminated soil in the area for reburial. The trench could then be refilled with clean soil. Little personnel exposure would result if appropriate clean-up procedures are followed and little environmental insult would occur outside the immediate area. 


\section{$5.2 .3 \quad$ Fire}

Low-level buried waste contains wood, paper, cloth, and other combustible materials and thus presents a potential fire hazard. Small fires have occurred very infrequently in the past primarily in waste trenches. The resulting damage and contamination from these fires has been very minimal and demonstrates the effectiveness of Laboratory personnel in handling this situation. High-level buried waste is essentially noncombustible and presents little fire hazard.

Fire involving low-level buried waste could occur within a dumpster in the main Laboratory area or in route to the storage area, or by combustion of the waste emplaced in a trench which has not yet been backfilled. To this date a fire has not occurred in a dumpster. All the waste is packaged before being placed in a dumpster and has limited oxygen for combustion. Additionally, in recent years, the dumpsters are kept locked and Health Physics personnel must be present to unlock the dumpster and witness the transfer of waste to the dumpster. This ensures more rigid control on what is being placed in dumpsters. If, however, a fire did occur inside a dumpster, the event would be reported to the ORNL Fire Department which is on duty 24 hours per day and has firefighters trained in the handling of radioactive fires. A Health Physics surveyor responds to all fire alarms as a part of the emergency team and would ensure that the area was evacuated, if necessary, and that the individuals involved in combating the fire had adequate safety equipment. Then the fire is adequately contained, the area would be surveyed and any necessary clean-up or decontamination operation initiated. The dumpster, when closed, would provide some containment of the radioactivity released by the fire as well as restricting the flow of oxygen to the fire.

A fire occurring in a partially filled trench would be handled in basically the same manner with the fire department responding to the fire followed by appropriate cleanup of the area, burial of contaminated soil, etc. Trench fires have occurred in the past with little internal or external personnel exposure or spread of contamination. Appendix A contains an evaluation of the results of a hypothetical trench fire. 
No unreacted liquid metals, organics, or other flammable liquids are routinely disposed of in the SWSAs. Pyrophorics, oxidizing agents, and other such materials also are not routinely accepted in the storage areas. If materials such as these are disposed of in the storage areas, the disposal would be handled as a special case with special approvals, procedures, and precautions as necessary.

\subsubsection{Trench Subsidence}

As buried waste containers deteriorate and decompose in the SWSAs, trench subsidence sometimes occurs. This presents no major safety hazards and is handled routinely as a part of the SWSA maintenance operations. Normally, when there is trench subsidence, the waste is not exposed and there is no potential for radiation exposures or spread of contamination. In the event the waste is exposed, appropriate precautions would be taken to prevent radiation exposures either internally or externally. The surrounding area would be surveyed for contamination and cleaned if necessary.

When trench subsidence occurs, it is noticed quickly through routine surveillance operations. All individuals who normally perform maintenance activities or disposal activities in the storage areas are aware of the importance of reporting any subsidence to SWSA management. When trench subsidence is discovered, clean fill dirt is brought in and the trench is refilled to its original level.

\subsection{STORED WASTE ACCIDENTS}

\subsubsection{Releases During Transport and Disposal}

Little potential exists for a release of radioactive material during transport and disposal of stored waste. The stored waste is packaged in either stainless steel canisters or concrete casks for higher-level waste and in stainless steel drums for lower-level (less than $200 \mathrm{mrem} / \mathrm{h}$ ) waste. The packaging for all stored waste is designed to maintain integrity and prevent release of any of the transuranic waste for a minimum of 20 years. 
The stainless steel canisters are either fully welded construction or may contain a flanged end for loading the waste. The waste is loaded in the canister inside a hot cell, and the canister is placed in a shielded carrier similar to the ones used for tranport of the high-level buried waste. As in Section 5.2.1, the carrier could either be dropped by a crane or from the transport vehicle, and the access cover could conceivably open and expose the contents. The waste is contained in the stainless steel canister inside the cask and would not likely be released. A large radiation field would exist through the open carrier and appropriate Health Physics precautions would be taken until the carrier could be closed or sufficiently shielded. The radiation level of the inner canister varies widely, but experience indicates that most would indicate less than $2,000 \mathrm{rem} / \mathrm{h}$ at one foot. This would result in readings of $20 \mathrm{rem} / \mathrm{h}$ at $10 \mathrm{ft}$ and $0.2 \mathrm{rea} / \mathrm{h}$ at $100 \mathrm{ft}$. Both distance and temporary shielding could be used in minimizing personnel exposures in returning the canister to the carrier.

The concrete casks are also loaded in hot cells and transported to the storage areas on low-boy trailers. Detailed procedures exist for the loading and transport of the concrete casks. The procedure specifies the load capabilities of the transport vehicle and the lifting equipment. It calls for visual inspection of all lifting slings before each lift of the cask. All slings are certified for use through nornal ORNL safety procedures. The procedure also calls for an escort vehicle with flashing lights both in front and behind the transport trailer. The precautions outlined in the procedure minimize the possibility of a dropped cask or of a transport accident in route to the storage area. However, the cask construction is reinforced concrete, and there is little chance that the cask would be ruptured if dropped the short distances involved in loading and transporting to the storage area. Additionally, the waste inside the cask is packaged in metal or plastic containers and surrounded by a layer of plastic. The probability is very small that any contamination would be released from the cask as a result of any transport accident. 
The low-level stored waste is packaged in stainless steel drums with a plastic liner inside the drum as a minimum. The most likely situation for damaging one of these drums is during the loading process at the storage facility. The drums are placed in a staging facility, Building 7823, temporarily until several have accumulated and then are moved into the permanent storage facility, either Building 7826 or 7834 . The drums are lifted into the facility four at a time with a crane. If a drum were dropped during the loading operation into the storage facility, the drum could fall as far as 16 to $18 \mathrm{ft}$ to a concrete floor slab if the cell being loaded were empty. This drop could rupture the drum and expose the material inside. Due to the low level of the waste, radiation would not be a major problem. The problem would be in cleaning up any released material. If necessary, the cell could be sealed off and a temporary ventilation system placed in service to contain the radioactivity. Personnel appropriately dressed could then enter the cell and clean and decontaminate the cell. The ruptured container and its contents could either be placed in an overpack drum and stored in the facility, or the drum and its content could be bagged out and carried to a hot cell where the material could be repackaged into another drum and replaced in the facility.

The arums are approved transport drums for radioactive waste, DOT Spec $17 \mathrm{H}^{11}$; and there is little possibility that a drum would be ruptured during the low-speed transport from the Laboratory to the storage area.

\subsubsection{Natura1 Phenomena}

All stored waste is located in SWSA-5/north in special trenches or concrete storage facilities. All these facilities are well above the maximum probable flood elevation of $240.9 \mathrm{~m}$ (790.5 ft) and would not be subject to flood damage. The buried casks are in trenches below grade and would not be subject to tornado damage. An earthquake could expose a cask in the trench but would not likely rupture the cask. The concrete provides adequate shielding for personnel protection if the cask is exposed. 
The stainless steel wells also are below grade and would not be subject to either earthquake or tornado damage. The concrete plugs cannot be removed by the assumed design basis tornado, and the double stainless steel containment ensures that the material would remain contained during an earthquake. The concrete slab on the surface of the well facility would provide adequate shielding for personnel protection. All the concrete cask and drum storage facilities 7826,7834 , and 7855, are designed and constructed in accordance with the NRC Regulatory Guide 1.76 tornado specifications and the Zone 2 seismic requirements specified in the Uniform Building Code. The sheet metal roof sections of Building 7826 could be removed during a tornado, but the structural steel framework below would prevent the drums from being removed. The concrete plugs in Building 7834 are too heavy to be removed by the assumed design basis tornado.

The staging facility, Building 7823, is not designed for tornado and earthquake resistance and would be subject to damage. The facility, however, is mostly below grade with only the overhanging saddle roof exposed. A tornado would likely remove this roof, but the steel structure of the building should remain intact. The remaining structure and the below-grade position of the stored drums would offer protection from the tornado forces. The drums would be scattered within the structure and possibly some would be ruptured, but the fencing attached to the roof structure would prevent any drums from being removed from the facility. Some material from the ruptured drums would be removed from the facility and redeposited elsewhere. The use of the facility for temporary collection of drums until enough have accumulated to justify transfer to a cell in the permanent facility ensure that a maximum of one cell's drums, 80 drums, will be present in the staging facility at any given time and thus will minimize the amount of material which could be distributed. This, in conjunction with the very low probability of a tornado on the ORNL Reservation, greatly reduces the risk of a significant environmental insult from the drums in the staging facility. 


\section{3 .3 Fire}

The packaging of all stored waste in closed containers such as the canisters, drums, and casks leaves little chance for the initiation of a fire in any of the stored waste. Most of the combustible material is contained in the low-level stainless steel drums. In the event a fire did occur, the drums would reduce the probability of the fire spreading to another drum. Additionally, the compartmentalization of the storage facility would restrict the combustion to a single cell. The fire department would be notified and the fire would be extinguished after which cleanup would be initiated. If necessary, a temporary containment system could be placed on the subject cell to facilitate containment of any released material.

As with the stored waste, pyrophoric materials, organics, and other such materials are accepted only under special conditions and with special handling with due regard for the hazardous nature of the material.

\section{3 .4 Loss of Container Integrity}

The drum and casks in the Storage Facilities 7826, 7834, and 7855 can be monitored for loss of container integrity through use of sampling basins in the building drain system, through air sampling of the ports in the top of each cell, or possibly, through the use of a borescope or other optical device entering the facility through the roof ports. If a drum deteriorates to an unacceptable condition, the cell can be opened; and the subject drum can be placed in an overpack drum designed to contain the 55-galion drums. These overpack drums are constructed of mild steel and stocked in limited supply to be available when needed. The overpack drum can be restored in the facility or can be removed to a hot cell or other contained area for repackaging of the contents of the suspect drum.

If a drum has deteriorated to the point of releasing material into the cell, a containment enclosure could be constructed over the subject cell, the plug removed, and the material bagged out and removed to a hot cell for repackaging; or the material could be placed in an overpack drum. 
The concrete casks are not expected to deteriorate within the storage facility but may be inspected through the methods above for any signs of an unusual problem. The stainless steel canisters in the wells are likewise not expected to encounter any deterioration problems; however, they may be inspected if desired by removal of the plug and viewing the canister with a mirror or other optical method.

\subsection{WASTE COMPACTOR FACILITY ACCIDENTS}

\subsubsection{Releases During Transportation}

Compactible waste is a segregated form of low-level buried waste and thus is subject to the same transportation hazards as outlined in Section 5.2.1. Compactible waste is collected in special dumpsters and transported via the same methods as the buried waste. If a dumpster were to be dropped or damaged, some local spread of contamination wolld probably result. Appropriate measures would then be taken to clean up the area and little permanent damage or contamination would result. Once the waste has been compacted into bales and is ready for burial, the potential for release decreases due to the tightly bound nature of the bales. As additional protection, each bale is enclosed in plastic during the compaction process.

\subsubsection{Process Incidents}

The probability of a significant hazard resulting from a process incident at the Waste Compactor Facility is minimal. Only general lowlevel waste with a radiation level of $200 \mathrm{mrem} / \mathrm{h}$ or less is compacted at the facility. This material is segregated by the generator and is packaged and tagged for compaction. The generator ensures that the exterior surface of the package (plastic bag) is free of transferable surface contamination (transferable surface contamination measured by standard smear method is less than $30 \mathrm{dpm} / 100 \mathrm{~cm}^{2}$ for alpha emitters and $1000 \mathrm{dpm} / 100 \mathrm{~cm}^{2}$ for beta and/or gamma emitters). Compactor operating 
personnel are cautious not to open the package in normal operations. This ensures that the potential for spread of contamination inside the facility is very low.

The compactor contains a ventilation system with HEPA filtration. Air from the operating area is exhausted through the compactor ventilation system to the outside when the compactor is operating. The air in the operating area is sampled by constant air monitors (both alpha and beta/gamma) which activate a local alarm if abnormal amounts of airborne activity are detected. If the alarm sounds, the building would be evacuated and the equipment shut down until a Health Physics Surveyor monitors the area and determines that the facility is safe to enter.

Before compaction operations are initiated, the dumpster pan and its contents are visually checked by the operator to determine if the waste is properly packaged. Radiation readings are taken as deemed necessary and, if external contamination is suspected, smears are taken of representative packages and from the interior of the dumpster. The results of the survey will be evaluated by the SWSA supervisor and, if satisfactory, operations are initiated. The compactor exhaust must be functioning properly before compaction may begin. If any loose contamination is released by the compaction process, it is removed in the ventilation systern and captured in the HEPA filters. The compactor and compactor roon are monitored periodically during operation, and a Health Physics survey is completed at the end of each day in which the unit is operated.

After the dumpster is unloaded, the inside and outside surfaces are surveyed and cleaned as necessary prior to its being returned to collection service. Transferable contamination guidelines of $100 \mathrm{dpm} / 100 \mathrm{~cm}^{2}$ beta/gamma and $30 \mathrm{dpm} / 100 \mathrm{~cm}^{2}$ alpha are used in the cleaning process. The compacted bale is enclosed in plastic to contain any possible loose contamination during transport to the disposal trench. 


\subsubsection{Natural Phenomena}

The Waste Compactor Facility is located in SWSA-5/north near the retrievable waste storage facilities and is well above the maximum probable flood plain. Earthquakes and tornadoes were considered during the design phase of the facility and, due to the small amount of material present in the facility at any given time (equivalent to approximately one bale of compacted waste) and the low radiotoxicity of that material, it did not appear necessary or practical to design the facility for the design basis earthquake or tornado. The facility was designed to meet the Southern Building Code except for wind loading. A wind load of 25 $1 \mathrm{bs} / \mathrm{ft}^{2}$ ( $100 \mathrm{mph}$ wind) was used. In the highly improbable event an earthquake or tornado did destroy the facility, the small amount of radioactive material which would be scattered around the area would present a minimal environmental impact.

\section{4 .4 Fire}

The likelihood of a fire involving compactible waste is comparable to that of the buried waste (see section 5.2.3). If a fire occurs in a dumpster or in a trench, the Fire Department would be notified to extinquish it after which the appropriate clean-up operations would be initiated. Minimal hazard to personnel or the environment would result.

Inside the compactor facility, the amount of combustible material is maintained at a minimum. Only the volume of waste sufficient for the operation in progress is stored inside the facility. Presorting of the compactible waste by the generator ensures the absence of pyrophorics and other such hazardous materials. The bullding is equipped with smoke activated devices and manual pull boxes, both of which activate an alarm in the ORNL Fire Department headquarters. Portable fire extinguishers maintained and inspected by the ORNL Fire Department are located throughout the building. 


\subsubsection{Ventilation System Failure}

The ventilation system for the compactor consists of a fan, two roughing filters and two HEPA filters in parallel, and associated instrumentation. The fan removes air from inside the compactor chamber, passes it through the filters, and then releases the air outside the building. The air leakage into the chamber is from the operating area. The HVAC system in the operating area does not provide secondary containment but is primarily for heating and cooling. When the compactor ventilation system is operating, the operating area HVAC system is modified to eliminate recycle and avoid upsetting the temperature control of the area. This is necessary because the recycle configuration would not meet the increased air flow demands of the compactor ventilation and would pull unconditioned air into the operating area.

A failure of the ventilation system would present no serious problems. The system only operates when waste is being compacted during which time an operator is always present. If the ventilation system fails, the compactor would automatically be shut down by the monitoring instrumentation. With the compactor inoperable, there would be little potential for release of material inside the facility. Normal operating

procedure does not provide for containment ventilation of the waste either before or after but only during the actual compaction process. The compactor would remain inoperable until the ventilation was restarted.

If material were to be released into the operating area, it would be detected by one of the two constant air monitors. The area Health Physics Surveyor and the SWSA supervisor would immediately evaluate the situation and take appropriate action.

\subsubsection{Failure of Services}

Failure of services to the Waste Compactor Facility would present no hazard. A service failure would instantly shut down the compactor if it were operating. As demonstrated in Section 5.4 .5 above, the compactor presents no potential hazard when inoperable. Previous experience has demonstrated that loss of electricity at the Laboratory is a very unusual occurrence. 


\subsection{IMPACT ON ADJACENT OPERATIONS}

Any hazardous occurrence in the SWSAs would have a minimal impact on adjacent Laboratory operations. SWSA-5 and SWSA-6, the two currently operating storage areas, are located in Melton Valley and are reasonably secluded from the main Laboratory area. The only operating facility in the near vicinity of either of these areas is the Solid Waste Compactor, which is under the same supervision and control as the storage areas themselves. No through traffic is allowed in the SWSAs and access is limited to those involved in solid waste storage operations.

SWSA- 1 and -2 are located in the central Laboratory area; however, the dormant state of these storage areas provides little possibility of any hazardous occurrence which would provide an immediate and unexpected health hazard to Laboratory personnel. SWSA-6 is located ith the vicinity of Tennessee Highway 95 (White Wing Road), a public access road. However, adequate fencing and security is provided to prevent encroachment of any individual past the highway right-of-way. This provides an adequately safe distance from the operations in SWSA- 6 .

\subsection{HUMAN ERROR}

Human error could be a precursor to or contribute to several of the accident conditions identified in the previous sections such as transportation accidents, spread of contamination, fire, etc. The accidents as they are discussed are generic with respect to cause and, thus, would present no greater consequences or risk as a result of human error.

Two potential accidents with respect to waste compactor operations do result directly from human error. These are external contamination. of the waste packages from the generator and shutdown or failure to start the compactor ventilation system when compacting is in progress. Health Physics personnel involvement by way of radiation surveys and smears help reduce the risk from external contamination and autonatic shutdown circuitry prevent the compactor from operating without the ventilation system functioning. 
Operating procedures for all SWSA operations as well as assistance from Health Physics personnel in accordance with the Health Physics Procedure Manual help reduce the consequences of human error in SWSA operations.

\subsection{RISK}

The risk from potential abnormal operations and conceivable accident situations are summarized in Table 5.3. 
Table 5.3. Risk of solid waste disposal operations

\begin{tabular}{|c|c|c|c|c|}
\hline Incident & Reference & Consequence & Probability & Risk \\
\hline \multicolumn{5}{|l|}{ Impact of normal operations } \\
\hline $\begin{array}{l}\text { Spread of contamination during transport, } \\
\text { handling, or disposal }\end{array}$ & 5.1 & Low & Low & Low \\
\hline $\begin{array}{l}\text { Exposure of operating personnel to high } \\
\text { radiation field }\end{array}$ & 5.1 & Low & Low & Low \\
\hline $\begin{array}{l}\text { Unacceptable leakage from SWSAs (releases } \\
\text { to the Clinch River from White Oak Dam } \\
\text { in excess of established limits) }\end{array}$ & 5.1 & Medium & Very low & Very low \\
\hline \multicolumn{5}{|l|}{ Buried waste operations } \\
\hline $\begin{array}{l}\text { Transportation accident with high radia- } \\
\text { tion level waste (shielded carrier) }\end{array}$ & 5.2 .1 & Low & Low & Low \\
\hline $\begin{array}{l}\text { Transportation accident with low radia- } \\
\text { tion level waste (dumpster) }\end{array}$ & 5.2 .1 & Low & Low & Low \\
\hline Tornado traveling across open trench & 5.2 .2 & Medium & Very low & Low \\
\hline Earthquake exposes waste in closed trenches & 5.2 .2 & Low & Low & Low \\
\hline Fire in a waste collection dumpster & 5.2 .3 & Low & Low & Low \\
\hline $\begin{array}{l}\text { Fire in a full uncovered trench } \\
\text { (maximum credible accident) }\end{array}$ & $\begin{array}{l}5.2 .3 \text { and } \\
\text { Appendix } A\end{array}$ & Medium & Low & Medium \\
\hline Trench subsidence & 5.2 .4 & Very low & Medium & Low \\
\hline
\end{tabular}


Table 5.3. (continued)

\begin{tabular}{|c|c|c|c|c|}
\hline Incident & Reference & Consequence & Probability & Risk \\
\hline \multicolumn{5}{|l|}{ Stored waste oprations } \\
\hline Transportation accident with shielded carrier & 5.3 .1 & Low & Low & Low \\
\hline Transportation accident with concrete cask & 5.3 .1 & Low & Low & Low \\
\hline $\begin{array}{l}\text { Transportation accldent with stainless } \\
\text { steel drum }\end{array}$ & 5.3 .1 & Low & Low & Low \\
\hline $\begin{array}{l}\text { Dropping of stainless steel drum(s) in } \\
\text { storage facility }\end{array}$ & 5.3 .1 & Low & Low & Low \\
\hline Tornado damage to staging facility & 5.3 .2 & Medium & Very low & Low \\
\hline Fire in stored waste & 5.3 .3 & Very low & Very low & Very low \\
\hline Loss of container integrity & 5.3 .4 & Very low & Medium & Low \\
\hline Waste Compactor Facility operations & & & & \\
\hline Contamination of waste packages - human error & 5.4 .2 & Low & Low & Low \\
\hline Natural phenomena & $5.4 \cdot 3$ & Low & Low & Low \\
\hline Fire & 5.4 .4 & Low & Low & Lor \\
\hline Ventilation system failure & 5.4 .5 & Low & Low & Low \\
\hline $\begin{array}{l}\text { Shutdow or failure to start ventilation } \\
\text { system - human error }\end{array}$ & 5.4 .5 & Very low & Low & Low \\
\hline Failure of services & $5.4 \cdot 5$ & Very low & Very low & Very low \\
\hline
\end{tabular}




\subsection{REFERENCES}

1. F. T. Binford and J. R. Gissel, A Description and Safety Analysis of Solid Radioactive Waste Facilities and Procedures at the Oak Ridge National Laboratory, ORNL/CF/75-2-23, March 1975.

2. Operations Division, ORNL, Radioactive Solid Waste Operations Manual, current revision.

3. Oak Ridge National Laboratory, Health Physics Procedure Manual, current revision.

4. Oak Ridge National Laboratory, ORNL Safety Manual, current revision.

5. Oak Ridge National Laboratory, ORNL Emergency Manual, current revision.

6. J. R. Gissel, A Description and Safety Analysis Report of the Radioactive Solid Waste Compactor Facility, Building 7831, ORNL/CF-78/242, July 1978.

7. E. M. King, Personal Communication, August 1980.

8. T. Tamura, et al., Progress Report of Disposal Area Studies at Oak Ridge National Laboratory: Period of October 1, 1975 to September 30, 1977, ORNL-5514, January 1980.

9. T. L. Miller, Solid Waste Disposal Cask - TRU Facility, Plant and Equipment Division Procedure M.3.4, May 1968.

10. T. L. Miller, Handling and Transfers of Shielded Containers, Plant and Equipment Division Procedure M.3.6, April 1969.

11. Title 49, Code of Federal Regulations, Part 178, Shipping Container Specifications. 


\section{QUALITY ASSURANCE}

\subsection{QUALITY ASSURANCE PROGRAM DESCRIPTION}

The ORNL Quality Assurance (QA) Program was developed to satisfy requirements of OR 5700.6, "Quality Assurance,"I in which it is recognized "that normal industrial standard practice includes many actions of a quality assurance nature which are considered routine. These are quite sufficient to assure the quality of many DOE programs and projects, and may be relied upon when formal evaluation indicates that quality problems will not have significant consequences." The ORNL QA Program requires formal QA assessments by personnel from such disciplines as engineering, operations, QA, and safety. If the assessment leads to the conclusion that a failure has unacceptable consequences and that probability of failure is high or unknown, then additional actions are needed to lessen the probability of failure or to reduce the consequences of that failure. In the QA Plan, the additional actions, the responsible organizations or personnel, and dates for completion of the actions are identified.

In addition to the QA assessments and QA plans, the ORNL QA Program has procedures for controlling quality during all phases of a project. These procedures require complete review of all components and systems by appropriate personnel, including safety personnel. Design, construction, acceptance testing, operation, and maintenance of the project are all included.

\subsection{ORNL QUALITY ASSURANCE ORGANIZATION}

Quality Assurance activities at ORNL are coordinated by the QA Program Director, who reports to the Department Head for Quality Assurance and Inspection. The staff of $Q A$ specialists are principally responsible for $Q A$ audits, $Q A$ training and motivation, development of $Q A$ procedures, Engineering QA liaison, and QA application. Their activities are guided by the ORNL Quality Assurance Manual. ${ }^{2}$ Each division has one or more Quality Assurance Coorjinators appointed by the division director to 
coordinate the QA activities within that division. The QA coordinators, who are responsible to their division directors for the QA activities within their division, also inform the QA Program Director of division QA activities.

\subsection{OPERATIONS DIVISION QUALITY ASSURANCE PROGRAM}

The Operations Division QA Program supplements that of the Laboratory and is outlined in the "Operations Division QA Manual." 3 This manual contains instructions about $Q A$ implementation of the standard QA practices and job specifications for procurement of special materials and fabrications. The "Operations Division Procedures" 4 contains information about requirements for training and personnel qualifications, operating procedures, facility design changes, incident reporting, and operational audits.

\subsection{SWSA OPERATIONS QUALITY ASSURANCE}

The Division QA Manual ${ }^{3}$ is included by reference in the SWSA Operating Procedures which requires that all aspects of the QA program be met in SWSA operations. A Quality Assurance Assessment for SWSA operations is currently in preparation. This QA Assessment will identify the potential failure modes and concerns of the operations and will identify areas where special QA actions may be necessary. The assessment will be reviewed and approved by division management as well as divisional and ORNL QA Program representatives. 


\section{$6-3$}

\subsection{REFERENCES}

1. Quality Assurance, DOE-ORO, OR 5700.6, approved March 3, 1982.

2. Quality Assurance Office, ORNL, ORNL Quality Assurance Manual, current revision.

3. Quality Assurance Staff, Operations Division, ORNL, Operations Division Quality Assurance Manual, current revision.

4. Operations Division, ORNL, Operations Division Procedures, current revision. 


\section{CONDUCT OF OPERATIONS}

\subsection{ORGANIZATIONAL STRUCTURE}

The responsibility for the operation and maintenance of the SWSAs and associated facilities lies with the ORNL Operations Division. Responsibility was assumed by Operations from the Plant and Equipment Division in July 1973. Day-to-day operations are carried out by the Solid Waste Storage Group of the Radioactive Waste Management Operations Section (Fig. 7.1). All administrative functions of the operation are handled through division management.

Programmatically, Solid Waste Storage Operations are a part of the Nuclear Waste Program under the direction of the program manager for ORNL Waste Management Operations (Fig. 7.2). Operations Division management is responsible to the Executive Director for Support and Services; whereas, Nuclear Fuel and Waste Programs management is responsible to the Assoclate Director for Nuclear and Engineering Technologies, both of whom report to the Laboratory Director (Fig. 7.3).

Close liaison is maintained with the Industrial Safety and Applied Health Physics Division and the Plant and Equipment Division. The former provides Health Physics surveillance for the operation, and the latter supplies craft support personnel such as heavy equipment operators, truck drivers, laborers, etc., who perform much of the actual work. Technical support in the areas of hydrology and geology is provided by the ORNL Environmental Sciences Division.

Additionally, the operation is under the survelllance of the Division Safety and Radiation Control officer as well as the ORNL Office of Operational Safety and the various Director's Review Committees. All operations must conform to the requirements of the ORNL Health Physics Procedure Manual as well as the Operations Division Radioactive Solid Waste Operations Manual and other applicable division procedures. Conformance with the Operations Division Quality Assurance Manual and the ORNL Quality Assurance and Inspection Section Procedures must be maintained for all solid waste operations. Reviews will be held as necessary by 


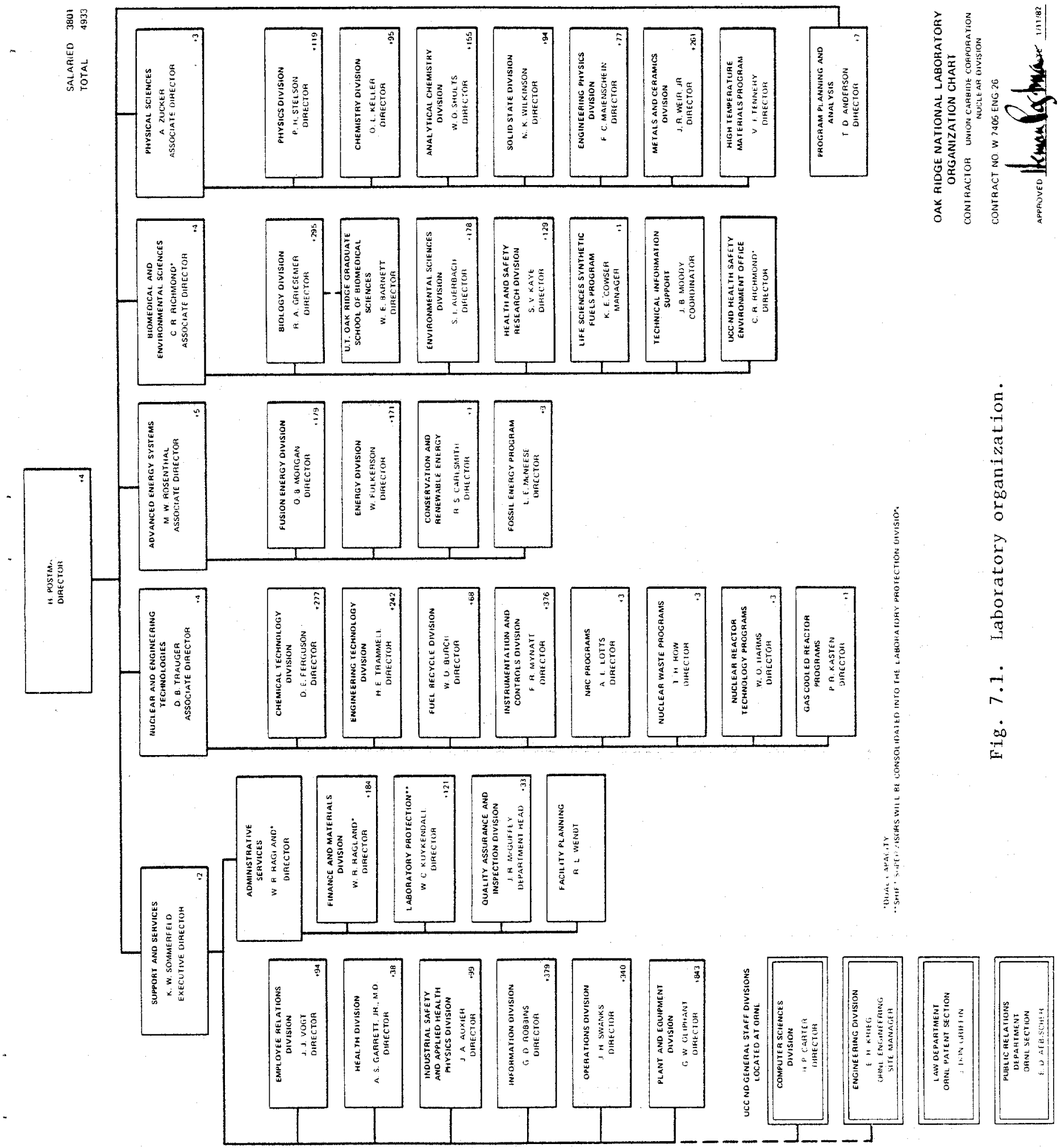




\section{PROGRAM MANAGEMENT IS STRUCTURED TO UNDERTAKE A BROAD EFFORT}

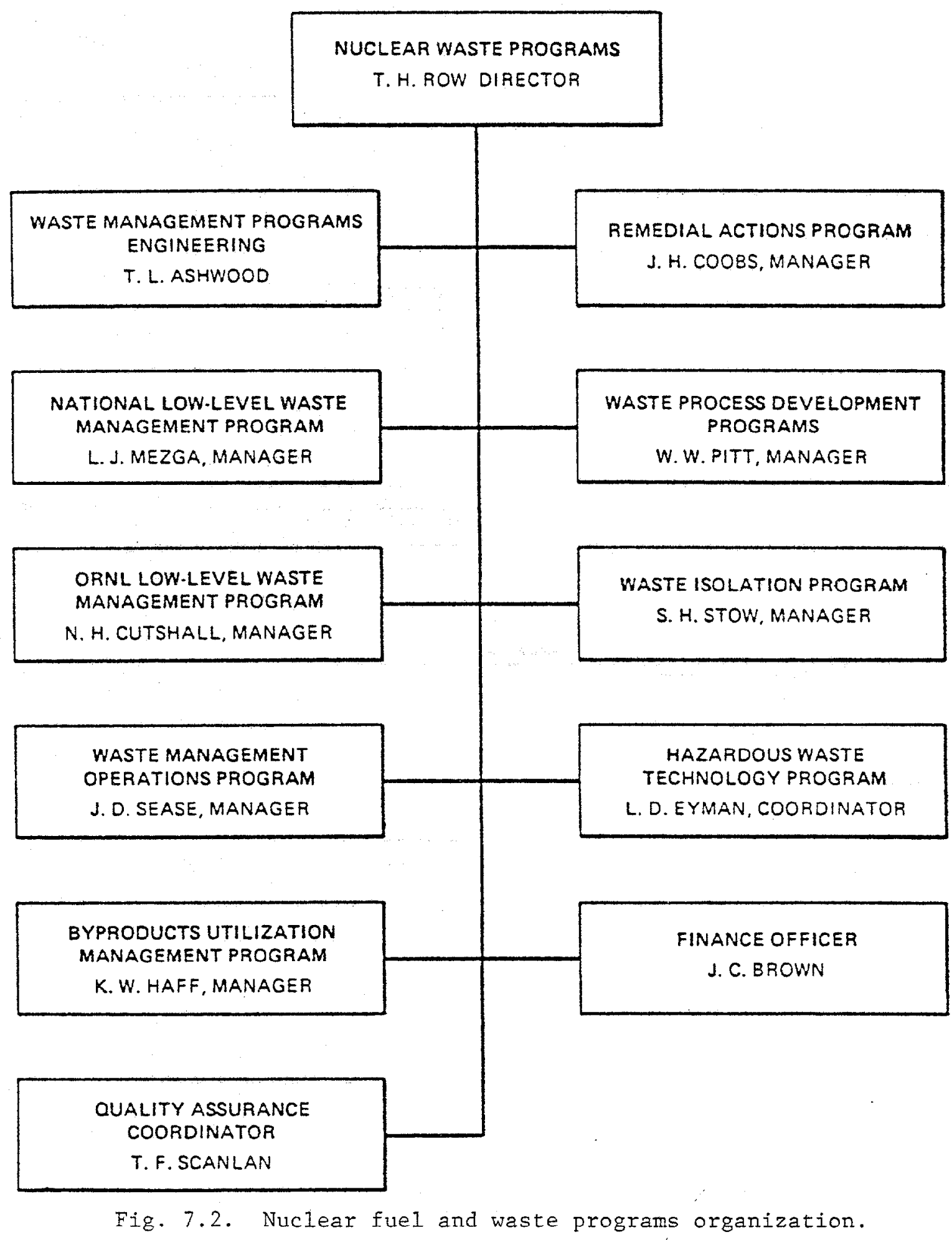




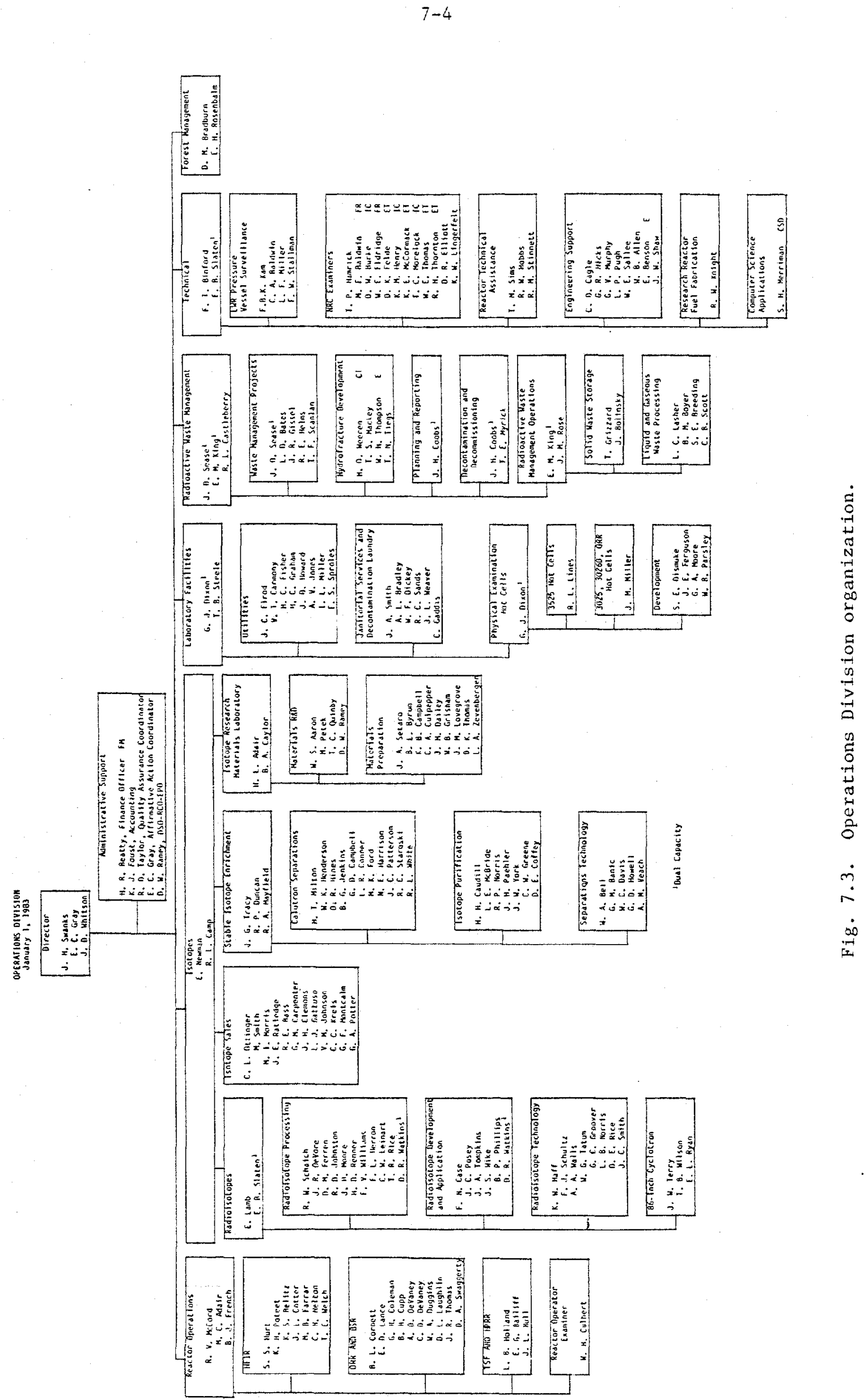


the Division Quality Assurance Coordinator. Quarterly operating reports and the Solid Waste Infornation Management System (SWIMS) reports reflect conformance with the Quality Assurance Program. Other groups such as the ORNL Environmental Coordinator's Office, the Laboratory Protection Division, and the Industrial Hygiene Section participate in operations as needed. The Safeguards and Special Materials Management Section (SSM Office) of the Laboratory protection Division maintains the official inventory records of source and special materials in the SWSAs.

Two Laboratory Director's Comittees, the Radioactive Operations Comittee and the Criticality Committee, are involved in review and approval of solid waste operations. The Radioactive Operations Committee is a group of knowledgeable individuals appointed by the Laboratory Director with primary interface through the Office of Operational Safety. The committee's dutles involve review and acceptance of Laboratory facilities or processes handling significant quantities of radioactive materials. These facilities include the solid, liquid, and gaseous waste disposal facilities. The committee is concerned with such items as containment of radioactive material, completeness and accuracy of the operator's safety analysis documentation, operating prodecure, and the possibilities of interactions which lead to unplanned exposures or contamination.

The committee reviews all new facilities prior to Initiation of operations; reviews existing facilities whenever changes in operation are proposed; and periodically reviews more important facilities at intervals of one to three years even through no changes in purpose or scope have been made or requested. Frequency is dependent on the magnitude of the operation and the hazard involved.

In adition to periodic review of SWSA operations, the committee also reviews, by request fron the Office of Operational Safety, special operations which are significantly different in some way such as radioactivity content, physical or chemical form, or bulk quantity or size for which normal approved procedures do not exist. 
The Criticality Committee is established and functions in much the same manner as the Radioactive Operations Comittee. The Criticality Committee has review and approval jurisdiction over operations which involve handling, storing, transporting, and disposing of signiflcant quantities of fissile materials. With respect to solid waste operations, the committee has established limits on the quantities of fissile material in each of the routinely used solid waste disposal containers and also disposal facilities such as auger holes. Approval for operations involving masses of fissile materials in excess of the established limits must be obtained by submission of a "Request for Nuclear Safety Review" to the committee. The comittee will then make recommendations regarding the specific operation. The committee provides information and assistance in problems involving criticality and conducts a periodic review of each facility or balance area possessing significant quantities of fissile material to ensure that approved procedures are being followed.

\subsection{OPERATING PRACTICE AND PROCEDURE}

\subsubsection{Waste Handling Responsibility}

The Radioactive Waste Management Operations Section of the Operations Division has responsibility for the operation of the facilities for the disposal and storage of radioactive waste at Oak Ridge National Laboratory. This responsibility within the section is delegated to a Solid Waste Storage Supervisor and a Solid Waste Storage Foreman. Other organizations both within and outside the division assist the foreman in carrying out his duties. All solid Waste Storage operations are conducted in accordance with formal operating procedures.

The Operations Division, and in particular the Solid Waste Storage Supervisor and Foreman, have responsibility for providing planning, organization, and leadership of activities related to storage or disposal of radioactive wastes within the SWSA. Operations Division generally is 
not responsible for sorting, packaging, identifying, perforning radionuclide assay, or other such descriptive Information. Responsibilities vary depending on the waste category; i.e., ORNL generated, on-site generated, or off-site generated wastes (see Section 4.1.2).

ORNL generated waste is that waste which is generated by ORNL personnel within the boundaries of Oak Ridge National Laboratory. The generating facility is responsible for preparing this type waste for disposal including necessary sorting, volume reducing, packaging, Health Physics surveying, identifying, documenting, depositing in approved containers, and contacting the Solid Waste Storage (SWS) Foreman to establish a schedule for transporting the waste from the collection point to the disposal site.

The Laboratory Protection Division Source and Special Materials Management Section is responsible for maintaining the official ORNL inventory records of source and special materials. The generator is responsible for informing the SSM office of transfers involving this type material by means of completing form UCN-2681, Record of SSN Transactions. No verification of the contents of the waste package is made by Operations personnel. Operations personnel will accept, transport (within the $X-10$ site), and deposit the waste package after the necessary reviews, approvals, procedures, and schedules are completed. The review process may include the Radioactive Operations Committee, the Environmental Coordinator's office, or others. Figure 7.4111 ustrates the responsibility for ORNL generated wastes.

On-site generated wastes are wastes generated by other Union Carbide and DOE facilities within the Oak Ridge area (see Section 4.1.2). The on-site generator is responsible for preparing the waste for disposal in accordance with approved ORNL and divisional practices and procedures for waste preparation and packaging. The generator is responsible for transporting the package in accordance with a prearranged schedule with the SWS Foreman and in accordance with all appl1cable Department of Transportation and State of Tennessee, City of Oak Ridge, and DOE-ORO traffic regulations. The SWS Foreman is responsible for scheduling the shipment, accepting the shipment, and disposing of the waste. The SWS Foreman will also initiate measures to recover the 
ORNL WASTE RESPONSIBILITY

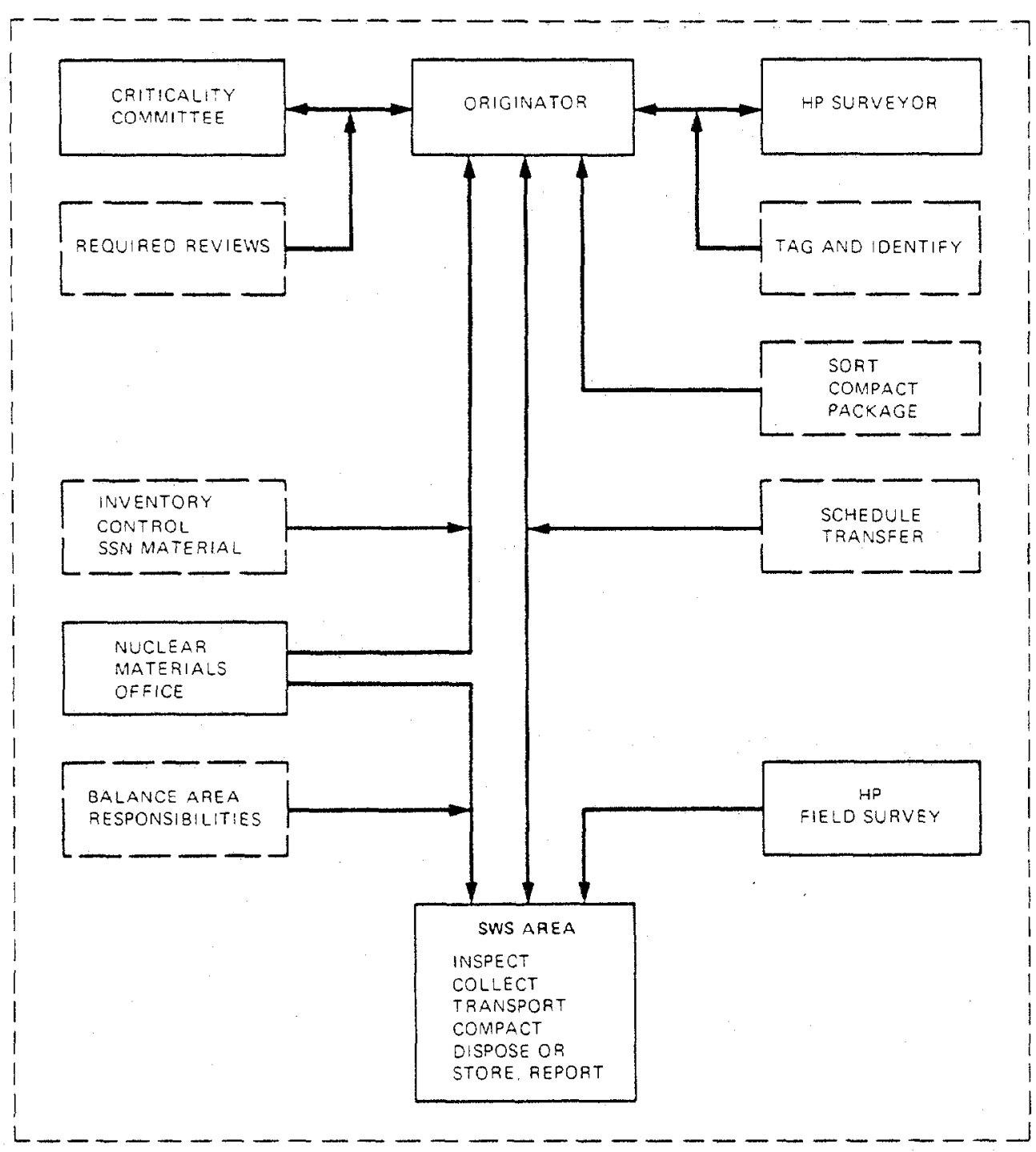

Fig. 7.4. ORNL waste disposal responsibility. 
costs of disposal. Nonroutine wastes are handled in a similar manner except the SWS Supervisor is responsible for obtainizg the necessary ORNL reviews and approvals for receipt of nonroutine wastes. Figure 7.5 illustrates the responsibility for on-site gererated wastes. The pricing schedule for routine disposal is reviewed periodically to ensure full cost recovery. Nonroutine disposal pricing is handled by the work order syster.

Off-site wastes are shipments of waste for disposal from generators outside the Dak Ridge area (see Section 4.1.2). The off-site generator is responsible for compliance with all applicable DOT and DOE regulations for shipment of the waste including approval for disposal of the waste at ORM from DOE-ORO. The Radioactive Waste Operations Section coordinates the details of the shipment and the acceptance of the waste fron the generator, including the required ORNL reviews and approvals. The SWS Supervisor and Foreman will be responsible for coorlinating the transport and disposal of the material once the carrier reaches the ORNL Reservation. Figure 7.6 illustrates the responsiblities for disposal of off-site generated waste.

\subsubsection{Disposal Practice and Limitations}

Waste disposal practices vary somewhat depending on the waste type such as fissile, trausuranic, general radwaste, low-hazard waste, etc.; but the differences are ninor and relate primarily to the disposal facility, i.e., trench, auger hole, storage building, etc., and the waste package. In general, all waste is packaged by the originator in accordance with the requirements of the Health Physics Manual for the type waste being packaged. At a minimum the waste package must be able to contain the waste until it is transported to the storage area and placed in the disposal facility. For transuranic waste, which are stored retrievably, the waste must be in doubly contained packages capable of maintaining integrity over long periods of time. The waste packages are sealed in some appropriate manner before transport to the storage area. Generally, packages exhibiting radiation levels in excess of $200 \mathrm{mrem} / \mathrm{h}$ 
ON-SITE WASTE RESPONSIBILITY

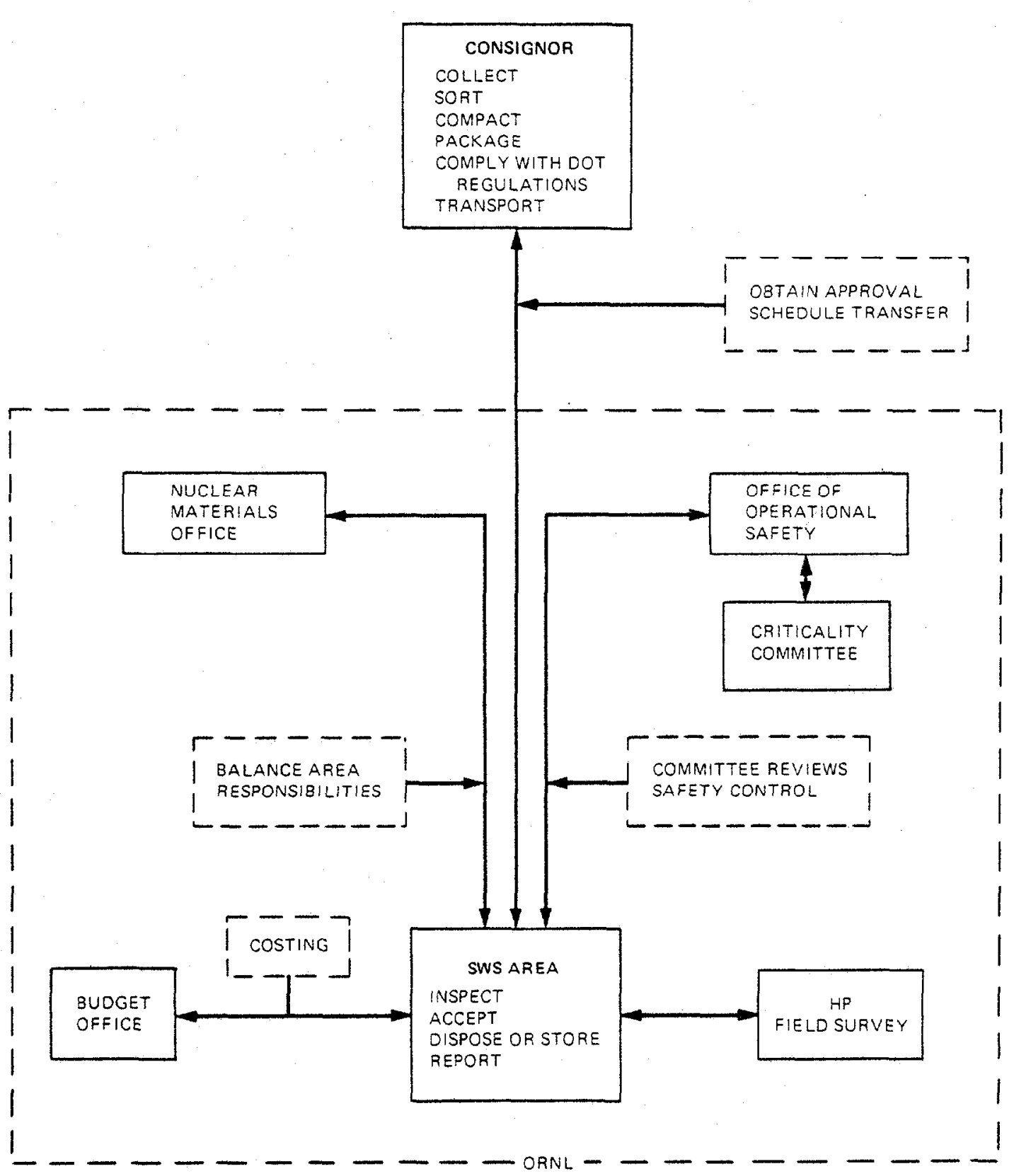

Fig. 7.5. On-site waste disposal responsibility. 
ORNL OWG $80 \cdot 16500$

\section{OFF-SITE WASTE RESPONSIBILITY}

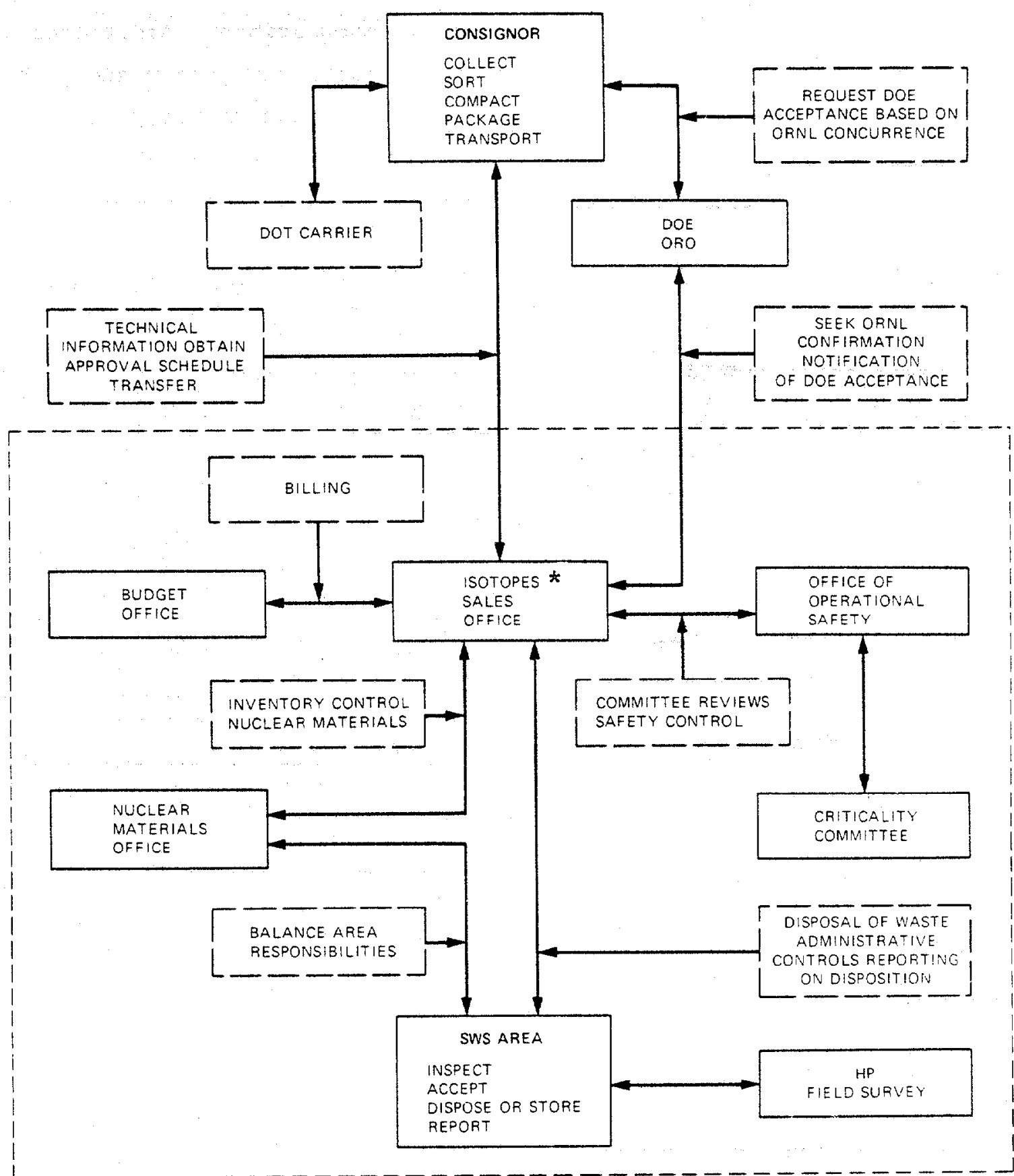

*Currently, the SwS personnel work directly with the consignor and other groups on the physical details of the transfer.

Fig. 7.6. Off-site waste disposal responsibility. 
will require some type of shielding for transport. When practical, the waste is segregated into combustible and noncombustible. Additionally, waste identified as compactible waste is packaged separately and placed in special dumpsters for transport to the compaction facility.

When the waste is packaged and appropriately surveyed and tagged, the generator completes a "Request for Storage or Disposal of Radioactive Solid Waste or Special Materials," UCN-2822 (Fig. 7.7), which gives information regarding the waste type, quantity, radiation level, surface contamination, and location of the waste as disposed of or stored.

Waste containing quantities of fissile material of one gram or more requires the completion of UCN-2681, "Record of SSN Transaction" before the waste can be transported to the storage area. Table 7.1 gives the maximum allowable quantities of fissile material for the various types of waste packaging. No special reviews are required when quantities of fissile material are maintained within these limits. These limits are based on a maximum concentration of $5 \mathrm{~g} / \mathrm{ft}^{3}$ or $200 \mathrm{grams} /$ container regardless of concentration.

When the necessary documentation and reviews have been completed, the waste is transported to the appropriate disposal or storage facility and emplaced there. In the case of auger holes and stainless steel wells, due consideration must be given to the limitation of 200 grams fissile material per well. The unique identification number and location of the wastes is recorded and transferred to the Solid Waste Inventory Management System computer program.

Waste which is nonroutine due to size, content, radiation level, or other characteristics is handled as a special case with appropriate review and approval. Special written procedures are prepared if the magnitude of the job requires it. If the waste or the packaging is found to be unacceptable in accordance with the established standards, the waste will be returned to the generator. If the unacceptable waste is from off-site, the problem is reviewed on an individual basis and appropriate action taken. The off-site generator would be notified of any problems and asked to correct them in the future. 
REQUEST FOR STORAGE OR DISPOSAL OF RADIOACTIVE SOLIO WASTE OR SPECIAL MATERIALS

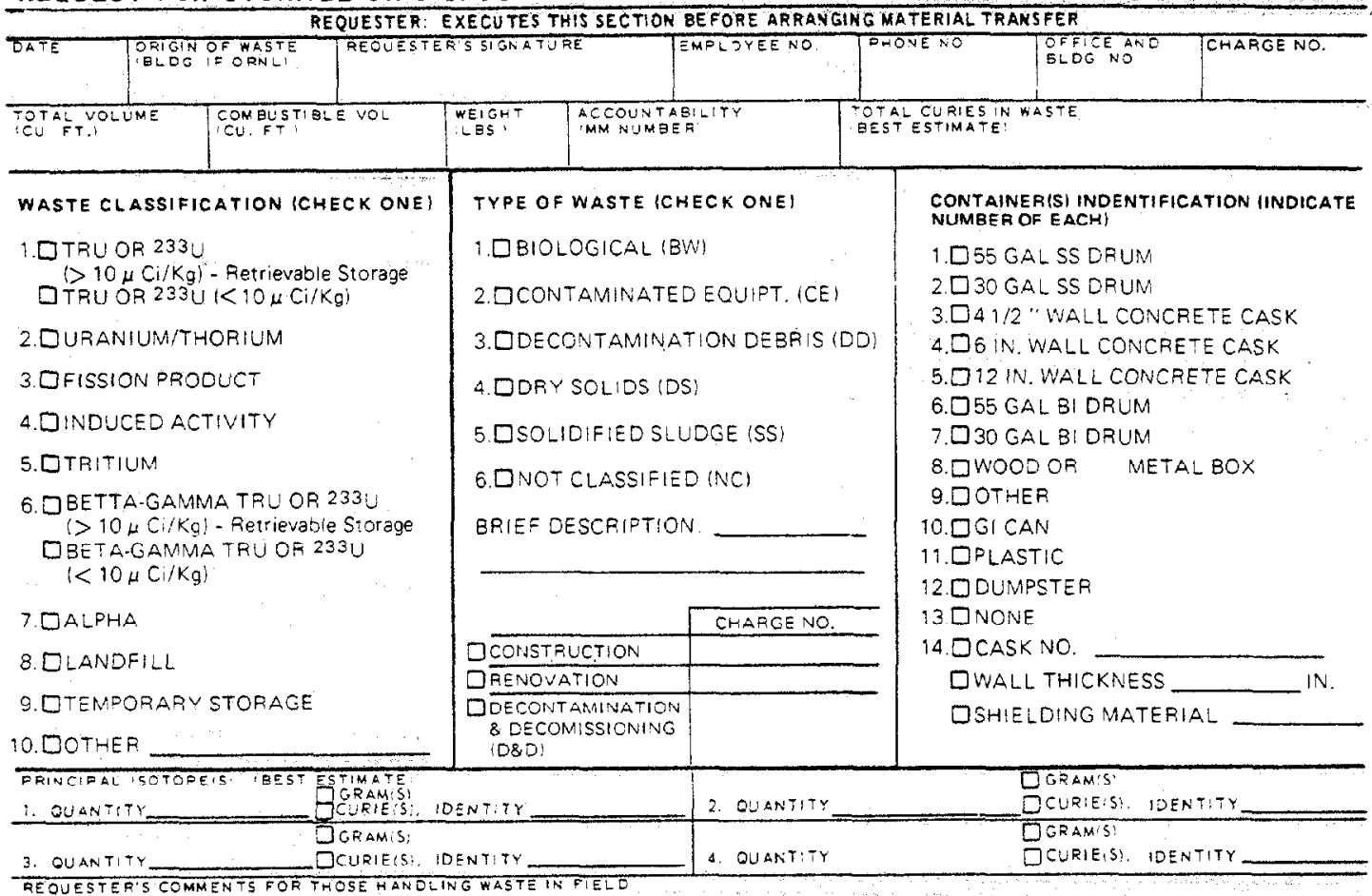

MEALTH PHYSICIST: EXECUTES THIS SECTION BEFORE MATERIAL TRANSFER

FROMTION DATA

BETA.GAMMA: FOR PACKAGE_ mrem in :_ IN OR FOR SHIELDEOCASK

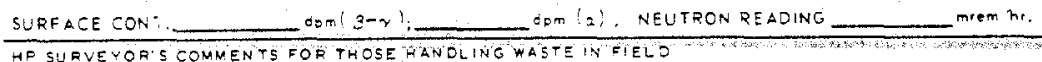

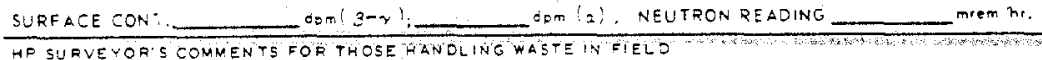

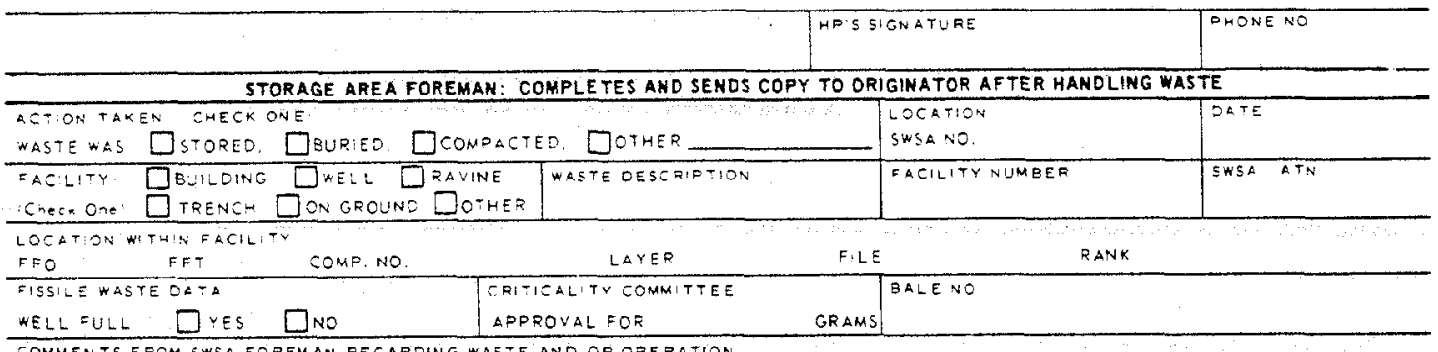

COMMENTS FFOM SWSR FOREMAN REGAROING WASTE AYO OR OPERATION

FOREMAN'S SIGNATURE

CANIRRY. RETAINEDGY ORIGINATOR

Fig. 7.7. Request for storage or disposal of radioactive solid waste or special materials. 
Table 7.1. Maximum operating limits for criticality control

\begin{tabular}{|c|c|c|c|}
\hline Disposal method & $\begin{array}{c}\text { Maximum fissile } \\
\text { content }\end{array}$ & $\begin{array}{c}\text { Departmental } 2 \\
\text { contro1 }\end{array}$ & $\begin{array}{c}\text { Disposal } \\
\text { classification }\end{array}$ \\
\hline Trench & $1 \mathrm{gram} / \mathrm{ft}^{3}$ & $1 \mathrm{gram} / \mathrm{ft}^{3}$ & Nonretrievable \\
\hline Unlined we11 & 600 grams & 300 grams & Nonretrievable \\
\hline $\begin{array}{l}\text { Stainless steel drum } \\
\text { 55-gallon }\end{array}$ & 200 grams & 100 grams & Retrievable \\
\hline $\begin{array}{l}\text { Stainless steel drum } \\
\text { 30-gallon }\end{array}$ & 100 grams & 55 grams & Retrievable \\
\hline Concrete cask $100 \mathrm{ft}^{3}$ & 800 grams & 500 grams & Retrievable \\
\hline $\begin{array}{l}\text { Stainless steel lined } \\
\text { wells (al1 except } \\
\text { Well 21) }\end{array}$ & 800 grams & 500 grams & Retrievable \\
\hline $\begin{array}{l}\text { Stainless steel } \\
\text { Well } 21 \text { (spent } \\
\text { fuel magazine) }\end{array}$ & 1600 grans & 1600 grams & Retrievable \\
\hline
\end{tabular}

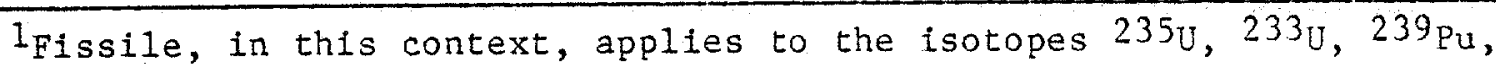
and $241 \mathrm{Pu}$. Other isotopes will require special approval.

2 Any disposal exceeding this quantity shall require prior approval from the office of Operational Safety. No disposal shall exceed the maximum fissile content without formal approval from the Criticality Comittee. 


\subsubsection{Volume Reduction Program}

An important aspect of current solid waste disposal operations is volume reduction. The available space on the ORNL Reservation satisfying the requirements for a solid waste storage or disposal area is very linited. Approximately 8.6 acres of usable space remains in SWSA-6. Current estimates indicate that 70 percent of this remaining space will be filled by 1985. Investigations are being conducted on a potential site for SWSA-7 but, at this time, no decisions have been made.

Early in FY 78, a formal program was initiated to reduce the volume of waste currently being buried at ORNL. This program has been very successful and continues to be emphasized. Some of the major actions of the program included: initiation of charging waste generators for waste disposal, procedural and operational changes placing emphasis on control of materials entering contamination zone, segregation of noncontaminated waste from the contaminated waste and locking of the major collection receptables (dumpsters), assignment of the key access control for the dumpsters to the Health Physics Surveyors, separation of low-level radioactive waste into a compactible fraction and a noncompactible fraction, initiation of a decontamination program, better packaging of waste to reduce voids and facilitate handing, and opening of a landf111 for suspect waste (no measurable contamination but judged to be unacceptable for disposal as noncontaminated waste).

The program has been heavily publicized by a series of posters identifying the major points of the program and stressing the importance of volume reduction. Figure 7.8 is a typical example of one of these posters. In addition to the publicity, team audits were made in all facilities generating solid radioactive waste to review the impact of the volume reduction program and to discuss any problems associated with the program.

The impact of the program can be seen by comparing the volume of waste buried in trenches and auger holes for FY-78 versus FY-79. (Table 7.2). A significant reduction in buried waste is obvious in FY-79 with the Volume-Reduction Program in effect. 


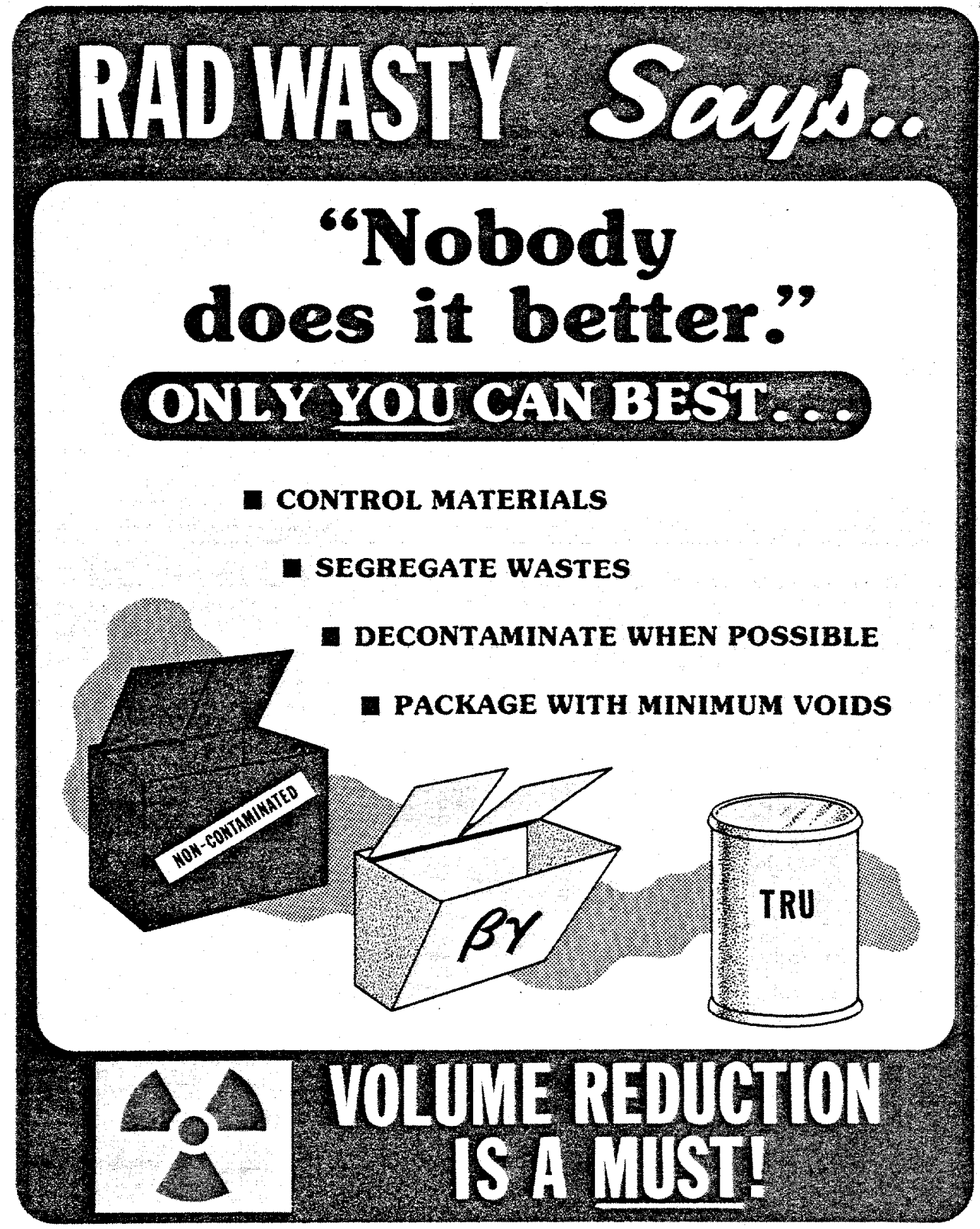

Fig. 7.8. Typical volume-reduction publicity poster. 
Table 7.2. Impact of Volume Reduction Program waste buried in trenches and auger holes, FY-78 versus FY-79

\begin{tabular}{|c|c|c|c|c|c|c|c|}
\hline \multirow[b]{2}{*}{ Quarter } & \multicolumn{2}{|c|}{ FY 1973} & \multicolumn{2}{|c|}{ FX 1979} & \multicolumn{3}{|c|}{ Reduction } \\
\hline & $\begin{array}{l}\text { Vo } \\
\mathrm{m}^{3} \\
\end{array}$ & $\begin{array}{r}\text { buried } \\
\mathrm{ft}^{3} \\
\end{array}$ & $\begin{array}{l}\text { Volume } \\
\mathrm{m}^{3} \\
\end{array}$ & $\begin{array}{r}\text { burled } \\
\mathrm{Et}^{3} \\
\end{array}$ & $\mathrm{~m}^{3}$ & $\mathrm{ft}^{3}$ & $\%$ \\
\hline October-December & 752.5 & 26,581 & 472.6 & 16,692 & 280.2 & 9,898 & 37 \\
\hline January-March & 600.7 & 21,218 & 311.0 & 10,986 & 289.7 & 10,232 & 48 \\
\hline Apri1-June & 420.1 & 14,840 & 266.5 & $9,413^{a}$ & 153.6 & 5,427 & 37 \\
\hline July-September & 481.2 & $16.997^{b}$ & 466.7 & $16,485^{c}$ & 11.7 & 412 & 2 \\
\hline
\end{tabular}

a Not including $12,070 \mathrm{ft}^{3}$ of waste from cleanup of Burial Ground 3 .

$\mathrm{b}_{\mathrm{A} 11}$ phases of the Volume Reduction Program were in operation during this period.

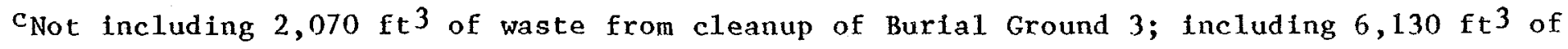
construction waste. 
Table 7.3 compares the total volume of beta-gama contaminated waste received in FY-79 to that finally buried in land suitable for trenches and auger holes. This illustrates the reduction in buried waste due to compaction of the compactible waste before disposal and the use of the landfill for low-hazard contaninated waste.

\subsection{SAFETY REVIEW SYSTEM}

As discussed previously (see Section 7.1) the Radioactive Operations Committee and the Criticality Comittee have responsibility for safety review and approval of Solid Waste Disposal operations. The Radioactive Operations Committee conducts periodic reviaws of the operation and makes approval and recommendations on special situations which are brought to their attention by SWSA management. The Criticality Comittee has reviewed the normal operation and established routine operating limits (Table 7.1). In addition to this, any operations which are abnormal or which exceed the specified limits are brought to the attention of the committee for resolution (form UCN-5917, "Request for Nuclear Safety Review").

All solid waste operations are under the review of the oRNL office of Operational Safety and the Division Safety and Radiation Control officer. Safety reviews of all divisional operations are conducted periodically by division management and other designated individuals.

Quality Assurance procedures are established and inspections are conducted by both division and Laboratory Quality Assurance personnel. The ORNL Environmental Coordinator's office monitors effluents from operations and advises on pollution and effluent control and regulations. Nonradioactive hazardous material problems fall under the direction and guidance of the ORNL Industrial Hygiene Section. 
Table 7.3. Impact of Volume Reduction Program FY-79 reduction due to compactor and landfill operations

\begin{tabular}{|c|c|c|c|c|c|c|c|}
\hline Quarter & $\mathrm{m}^{3}$ & $\left(f t^{3}\right)$ & $\begin{array}{c}\text { Buried in } \\
\text { and auger } \\
\mathrm{m}^{3}\end{array}$ & $\begin{array}{l}\text { trenches } \\
\text { holes } \\
\left(\mathrm{ft}^{3}\right)\end{array}$ & $\mathrm{m}^{3}$ & $\begin{array}{l}\text { Reduction } \\
\left(\mathrm{ft}^{3}\right)\end{array}$ & $\%$ \\
\hline October-December & 606.4 & 21,420 & 472.6 & 16,692 & 133.9 & 4,728 & 22 \\
\hline January-March & 432.0 & 15,259 & 311.0 & 10,986 & 121.0 & 4,273 & 28 \\
\hline Apri1-June & 374.4 & $13,224^{a}$ & 266.5 & $9,413^{a}$ & 107.9 & 3,811 & 29 \\
\hline July-September & 542.5 & $19,163^{b}$ & 466.7 & $16,485^{c}$ & 75.8 & 2,678 & 14 \\
\hline
\end{tabular}

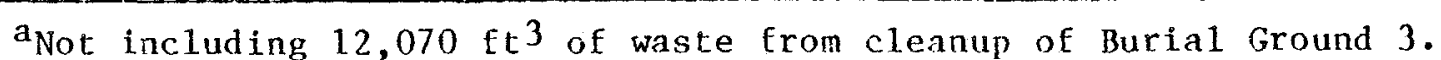

${ }^{b}$ All phases of the Volume Reduction Program were in operation during this period.

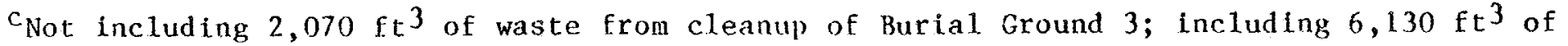
construction waste. 


\subsection{PERSONNEL TRAINING}

Organized training programs are conducted for all personnel involved in solid waste storage and disposal operations including SWSA supervisors, foremen, chemical operators, truck drivers, laborers, and riggers.

Supervisury persumel are trained in all aspects of radiation safety and control and radioactive solid waste disposal operations. This training includes familiarization with radiation/contamination hazards and proper safety procedures, operation of portable radiation survey equipment, familiarity with decontamination methods, and familiarity with all types of documentation and safety limits. On the job training is utilized along with instructional materials such as the Radioactive Solid Waste Operations Manual, the ORNL Health Physics Procedure Manual, the ORNL Safety Manual, the ORNL Emergency Manual, and the SWSA Safety Analysis Report and Operational Safety Requirements.

Candidates for SWSA supervisor and SWSA foremen will possess college degrees and high school diplomas or equivalent, respectively, with satisfactory achievenent in technical courses. Appropriate experience may be utilized interchangeably with education. Selection will include personal interviews, careful review of the candidate's employment history, and may include appropriate physical and aptitude tests.

Chemical operators must possess a high school diploma or equivalent experience and must be familiar with radiation safety and control and operational methods and procedures. Personnel such as power equipment operators, laborers, etc., are Plant and Equipment Division personnel, which are qualified for the special work they perform through the craft qualification system. Appropriate training is given in radiation control and safety.

Training of SWSA personnel is documented with the records maintained in the permanent files. Check-off sheets and oral reviews are utilized to ensure adequate completion of training. A formal program for retraining is not necessary. SWSA personnel must remain constantly 
familiar with all aspects of operating practice and procedure to effectively accomplish their job. Copies of the Operating Procedures, Health Physics Procedure Manual, OSRs, etc. are made available to personnel for reference as necessary. When changes in operation occur, SWSA management reviews the operating procedures and makes changes as required. All SWSA personnel are made aware of these changes as they occur.

\subsection{CONFIGURATION CONTROL}

Configuration control is maintained through adherence to operating procedures. Any deviation from normal operating procedures or limits requires special approval from knowledgeable groups such as the Radioactive Operations Committee, Criticality Committee, safety personnel, and Division management. All operations in the storage and disposal areas involving fissile material are covered by a "Request for Nuclear Safety Review." One such blanket authorization is maintained for normal operations covered by approved operating procedures with additional authorizations issued as needed for special occurrences. Operating procedures are reviewed and revised as necessary to accommodate changes in operating practice. Appropriate Quality Assurance reviews ensure that procedures are kept up to date with actual practice.

The Operations Division Procedure Manual outlines the appropriate method of handling design changes of operating facilities. This procedure requires that all design changes which require a modification of as-built drawings of a system or facility or is judged to represent a significant change to the facility or process shall be made through the use of a "Mechanical Design Change Memo" or an "Instrumentation and Controls Design Change Memo." The form identifies the required change, any drawing revisions or new drawings, and any required comittee reviews. The purpose of the form is to ensure that a design review is held and that the review is properly documented. When all changes have been properly completed, the change memo is signed by the facility supervisor 
or his designee to verify completion. If a change involves an unreviewed safety question or a change in operating safety requirements, a safety assessment shall also be prepared to accompany the change memo. Figure 7.9 illustrates the Mechanical Design Change Memo.

ORNL Engineering is responsible for maintaining current as-built drawings of trench and auger hole locations within the storage areas. Environmental Sciences Division routinely monitors to detect radionuclide movement within and away from the storage areas. Their results, conclusions, and recommendations are reported independent of Operations management.

\subsection{TESTING PROGRAM}

Continuous testing is conducted of Solid Waste Storage operations and facilities to ensure their continued safe operation. Ground water samples and surface stream samples are taken at specified frequencies and analyzed to evaluate storage area effectiveness. Sumps are provided in storage facilities to allow sampling of any water leakage in the facilities for contamination. Visual inspections are conducted as necessary to ensure integrity of the waste packaging.

Testing of the compactor filtration system as well as testing of various lifting and transporting components are done in accordance with standard Laboratory practice.

\subsection{EMERGENCY PLANNING}

Emergency response in the SWSAs is in accordance with standard ORNL emergency plans and philosophy as described in the ORNL Energency Manual. As defined in the plan, the person discovering the emergency takes immediate and appropriate action to protect personnel, prevent property damage, and bring the emergency under control. The individual would summon help by calling the ORNL Emergency Control Center phone number and reporting the nature of the emergency or by pulling the nearest fire alarm box and/or by notifying the local Emergency Supervisor. The individual would 


\section{OPERATIONS DIVISION \\ MECHANICAL DESIGN CHANGE MEMO}

\begin{tabular}{|c|c|}
\hline 1 FACILITr & CHANGENO \\
\hline 2 CWANGEMEMO PREATEEOTY & DATE \\
\hline 3 TITLE OF CMANGE & \\
\hline
\end{tabular}

S. PRIEF DESCRIPTION OF GMANGE IATTACH ADDITIONAL DETAILSIFNEEESSAAY

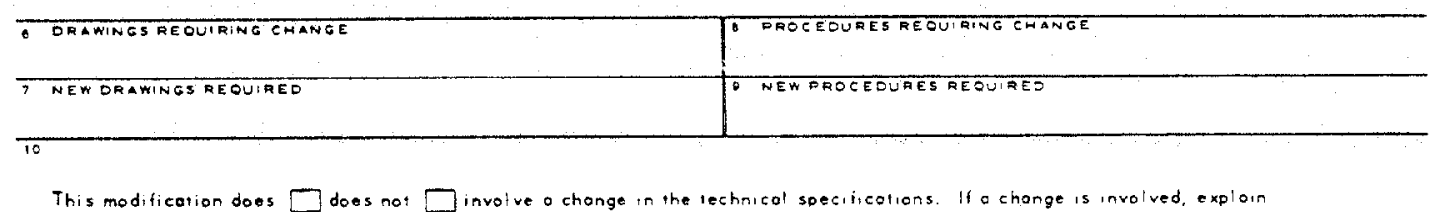

This modification does $\square$ does not $\square$ invotve o change in the lechnital specticetions. If a change is involved, explan

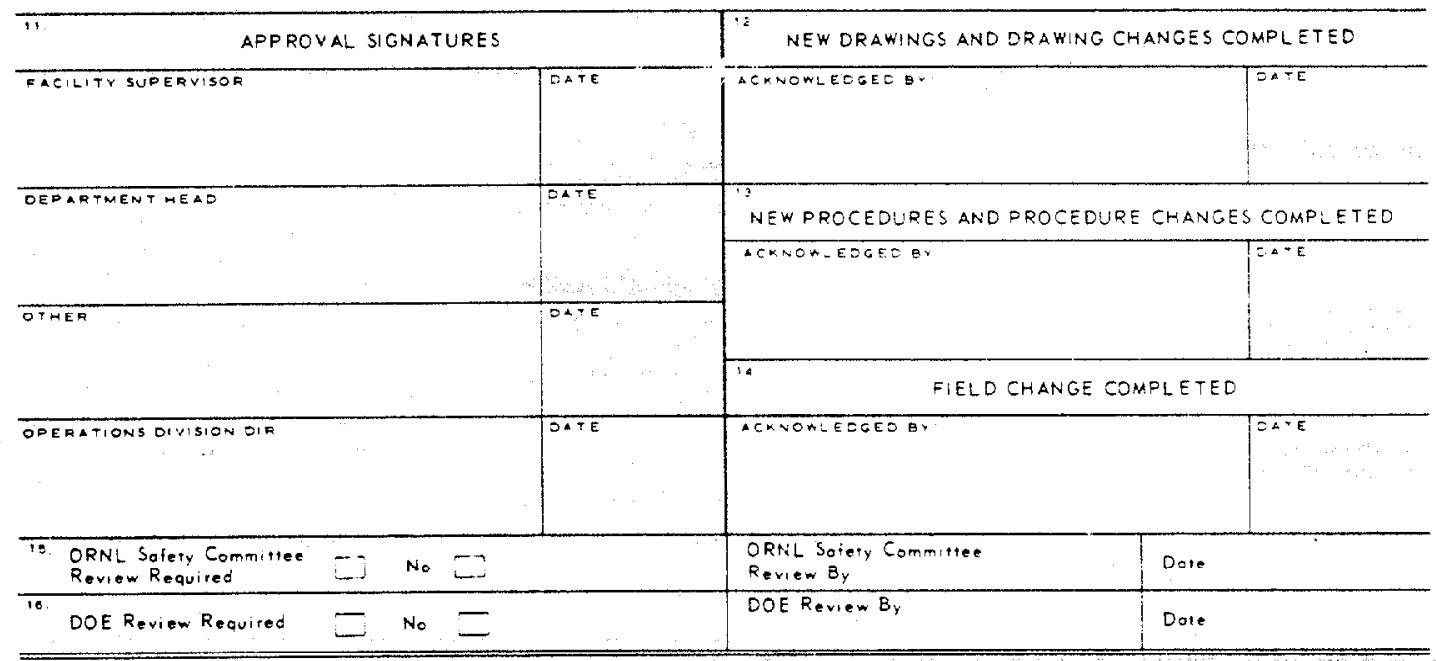

UCN.9798
(3.79)

Fig. 7.9. Mechanical Design Change Memorandum. 
take measures to combat the emergency if this can safely be done and would meet and orient the emergency service units as they arrive. The action of the Emergency Control Center after notification is detailed in the ORNL Emergency Plan.

The local Emergency Supervisor for the SWSAs is the SWSA Foreman on duty. The Laboratory Energency Director, the Laboratory Shift Supervisor on duty, is the overall coordinator for the operation. 


\subsection{REFERENCES}

1. F. T. Binford and J. R. Gissel, A Description and Safety Analysis of Solid Radiaactive Waste Facilities and Procedures at the Oak Ridge National Laboratory, ORNL/CF/75-2-23, March 1975 .

2. Operations Division, ORNL, Radioactive Solid Waste Operations Manual, current revision.

3. Nuclear Fuel and Waste Programs, ORNL, ORNL Waste Management Operations Annual Progress Report of Period Ending September 30, 1979, ORNL/NFW-79/72, November 1979.

4. Oak Ridge National Laboratory, Health Physics Procedure Manual, current revision.

5. P. M. Garrett, Technology for Energy Corporation, An Evaluation of Low-level Radioactive Waste Burial Ground Capacities at the Major DOE Reservations, ORNL/NFW-79/17, January 1979.

6. Oak Ridge National Laboratory, ORNL Safety Manual, current revision.

7. Oak Ridge National Laboratory, ORNL Emergency Manual, current revision. 
.

$*$ 
APPENDIX A - ACCIDENT ANALYSIS CALCULATIONS

Uncertainties in waste composition, the many varied types of wasto, variations in activity levels, etc., make it impractical and sometimes impossible to provide detailed quantitative safety evaluations of SWSA operations. In order to provide some quantitative basis to the evaluations of this safety analysis, a limiting case accident was chosen.

This accident, similar in concept to a "maximum credinle" or "design basis" accident, was chosen on the basis of its potential for occurrence as well as the severity of its consequences. This accident situation was identified in Table 5.3 of Section 5.7 as presenting the greatest overall. risk of all identified accidents. All other accident situations discussed in this safety analysis either present little potential for occurrence or have consequences potentially less hazardous than the limiting case.

The accident chosen for analysis is that of a trench fire in a completely full, but not yet backfilled, nontransuranic waste trench. The? fire is assumed to burn until all combustible material in the trench has been consumed and all activity in the waste is assumed to be entrained as particulate matter in the hot effluent from the fire.

\section{Assumptions regarding the trench and its contents}

The trench is assumed to be similar in design to that of Fig. 4.30 (ORNL Dwg. 74-8370R) with a length of $15.2 \mathrm{~m}(50 \mathrm{ft}$ ), a width of $3 \mathrm{~m}$ $(10 \mathrm{ft})$, and a depth of $3.7 \mathrm{~m}$ (12 ft). Allowing for a minimum $1 \mathrm{~m}$ ( $3 \mathrm{ft}$ ) of backfill above the waste, the total volume of waste would then be 127 $\mathrm{m}^{3}\left(4500 \mathrm{ft}^{3}\right)$.

A recent report by NUS Corporation for the Low-level Waste Pilot facility provides information on the average composition and activity level of the trench waste. 2 Type I waste is defined in the NuS report as waste having a surface contact dose rate of less than or equal to $200 \mathrm{mrem} / \mathrm{h}$. Type II waste is all waste above $200 \mathrm{mrem} / \mathrm{h}$. The waste in this accident analysis is assumed to have the following composition. 


$\begin{array}{ll}\text { Type } & \text { Combustibility } \\ 80 \% \text { Type I waste } & 50 \% \text { conbustible } \\ 20 \% \text { Type II waste } & 50 \% \text { combustible }\end{array}$

The corbustible fraction of the waste is assumed to have the following composition.

$\begin{array}{lr}\text { Paper and cloth } & 71 \% \\ \text { Plastic } & 23 \% \\ \text { Rubber } & 5 \% \\ \text { Wood } & 1 \%\end{array}$

The total heat content of the combustible fraction of the waste is assumed to be $1.6 \times 10^{8} \mathrm{BTU}$. The total activizy content of the waste in the trench is assumed to be 5,000 curies.

Meteorological Assumptions

Atmospheric dispersion calaulations shall be based on the annual. average wind speed of $2 \mathrm{~m} / \mathrm{s}$. Stabtlity Class D, neitral conditions, and stability Class $G$, very stable conditions, are assuned cor purpose of the analysis. Class $D$ is valid during a larger portion of the yeat than any other class (28\%) and thus represents the most probable case. class $G$ is generally accepted to provide the most conservacive analysis.

Isotopic Content

A detailed analysis of the isotopic content of the waste is provided in the NUS report. In order to sioplify the caloulations, a minimun number of different isotopes will be consjdered in the analysis. Analysis of the NUS data indicates that the following composition is representative of the isotopic content of the erench waste:

$\begin{array}{rr}25 \% & 1.37 \mathrm{Cs} \\ 75 \% & 90 \mathrm{Sr}\end{array}$


Theory

The basic equation used to estimate dispersion in an airborne plume downwind from a source is the standard Gaussian plume equation. With the receptor at ground level, the equation is as follows:

$$
\frac{X}{Q}=\frac{1}{\pi \sigma_{y} z^{\bar{u}}} \exp \left[-\left(\frac{Y^{2}}{2 \sigma_{y}{ }^{2}}+\frac{\Delta H^{2}}{2 \sigma_{z}^{2}}\right)\right] \text {, }
$$

where

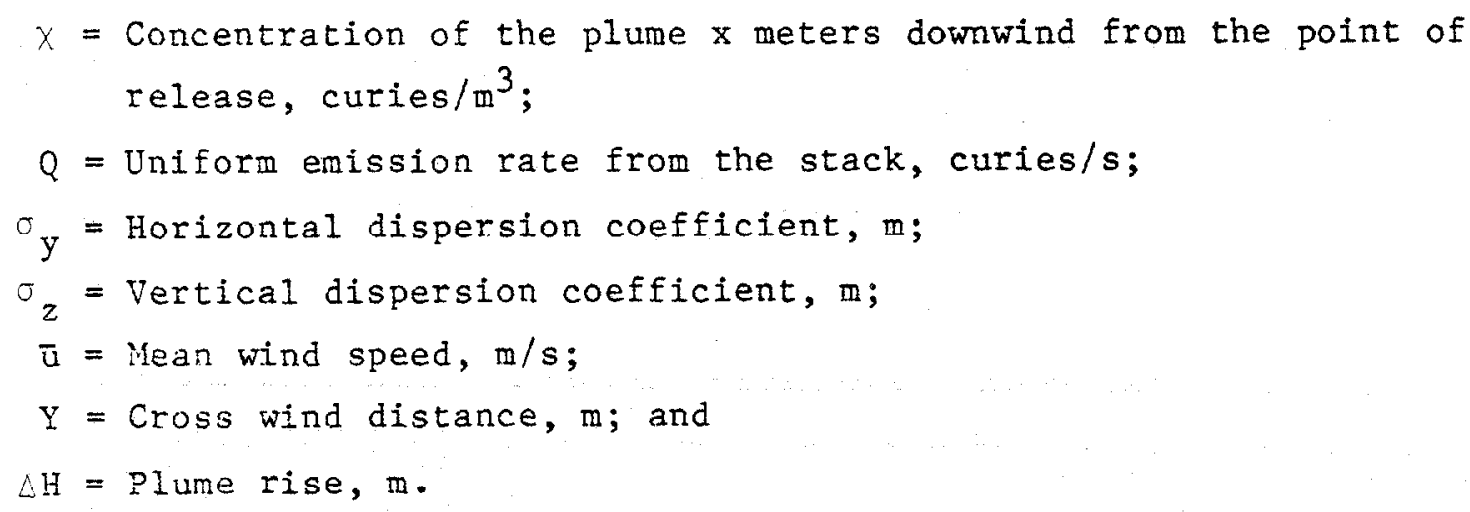

The analysis will utilize the maximum downwind concentration which occurs at the plume horizontal centerline and thus the cross wind distance, $Y$, is zero.

The dispersion coefficients, $\sigma_{y}$ and $\sigma_{z}$, have been approximated by Briggs ${ }^{4}$ for stability Class $D$ to be:

and

$$
\sigma_{y}=0.08 x(1+0.0001 x)^{-1 / 2}
$$

$$
\sigma_{z}=0.06 x(1+0.0015 x)^{-1 / 2}
$$

where $\sigma_{\mathrm{y}}$ and $\sigma_{z}$ are in meters and $\mathrm{x}$ is the downwind distance in meters. Similarly, the dispersion coefficients for stability Class $F$ are

and

$$
\sigma_{y}=0.04 x(1+0.001 x)^{-1 / 2}
$$

$$
\sigma_{z}=0.016 \times(1+0.003 x)^{-1 / 2}
$$


with the conversion to stability Class $G$ given by NRC Reg Guide $1.145^{8}$ as

and

$$
\sigma_{\mathrm{y}}(G)=2 / 3 \sigma_{\mathrm{y}}(\mathrm{F})
$$

$$
\sigma_{z}(G)=3 / 5 \sigma_{z}(F) \text {. }
$$

Methods of calculating the plume rise are provided by Briggs. 5 Buoyant plumes basically follow the " $2 / 3$ law" which is

$$
H=1.6 \mathrm{~F}^{1 / 3} \overline{\mathrm{u}}^{-1} \mathrm{x}^{2 / 3}
$$

where $F=3.7 \times 10^{-5} \frac{\mathrm{m}^{4} / \mathrm{s}^{3}}{\mathrm{cal} / \mathrm{s}} \mathrm{Q}_{\mathrm{H}}$, Buoyancy FIux Parameter and $\mathrm{Q}_{\mathrm{H}}=$ Heat emission in plume, cal/s or equivalent

$$
\begin{aligned}
& \overline{\mathrm{u}}=\text { Average wind speed, } \mathrm{m} / \mathrm{s} \\
& \mathrm{x}=\text { Horizontal distance downwind, } \mathrm{m} \text {. }
\end{aligned}
$$

The above equation is assumed to be valid up to a downwind distance of

$$
x=3 x^{*}
$$

at which point the rise becomes final.

The quantity $x^{*}$ must be approximated by the equation

$$
x^{*}=0.52 \frac{s^{6 / 5}}{f t^{5 / 6}} F^{2 / 5} h_{s}^{3 / 5}
$$

where $h_{s}$ is the estimated plume height. 


\section{Computations and Results}

Assuming the fire burns for a period of $30 \mathrm{~min}$ with a constant heat emission and activity release during the $30 \mathrm{~min}$ yields

$$
\mathrm{Q}_{\mathrm{H}}=2.2 \times 10^{7} \mathrm{cal} / \mathrm{s}
$$

and

$$
Q=2.8 \text { curies } / \mathrm{s} \text {. }
$$

On this basis, downwind plume concentrations, $x$, as a function of distance may be calculated. These concentrations converted to internal. and external dose rates are shown graphically in Figs. A.1 through A.4. The downwind plume concentration is highly dependent on the maximum plume rise which cannot be accurately predicted with the computational methods outlined herein. A study of Reference 5 indicates that $300 \mathrm{~m}$ plume rise may be reasonable to expect. This is based on actual plume rise data from the TVA Paradise Steam Plant which has an equivalent heat output. However, the plume is being emitted from a stack; and the wind speed during the measurements was considerably higher than assumed for the trench fire. Thus, the bounding cases of $200 \mathrm{~m}$ and $400 \mathrm{~m}$ plume rise were chosen for this analysis.

The internal dose estimates are based on a 50-year dose comitment from the inhaled activity during a $2 \mathrm{~h}$ constant exposure assuming that one percent of the airborne activity in the plume is respirable (Reference 1 ). The external dose is based on a $2 \mathrm{~h}$ immersion in a plume of constant concentration.

It should be noted that the calculations in this appendix are hand calculated estimates and should not be assumed to have the accuracy of modern computer models. However, the many assumptions necessary in defining the accident scenario preclude the necessity of such calculations. 
ORNL-DWG $82 \cdot 18519$

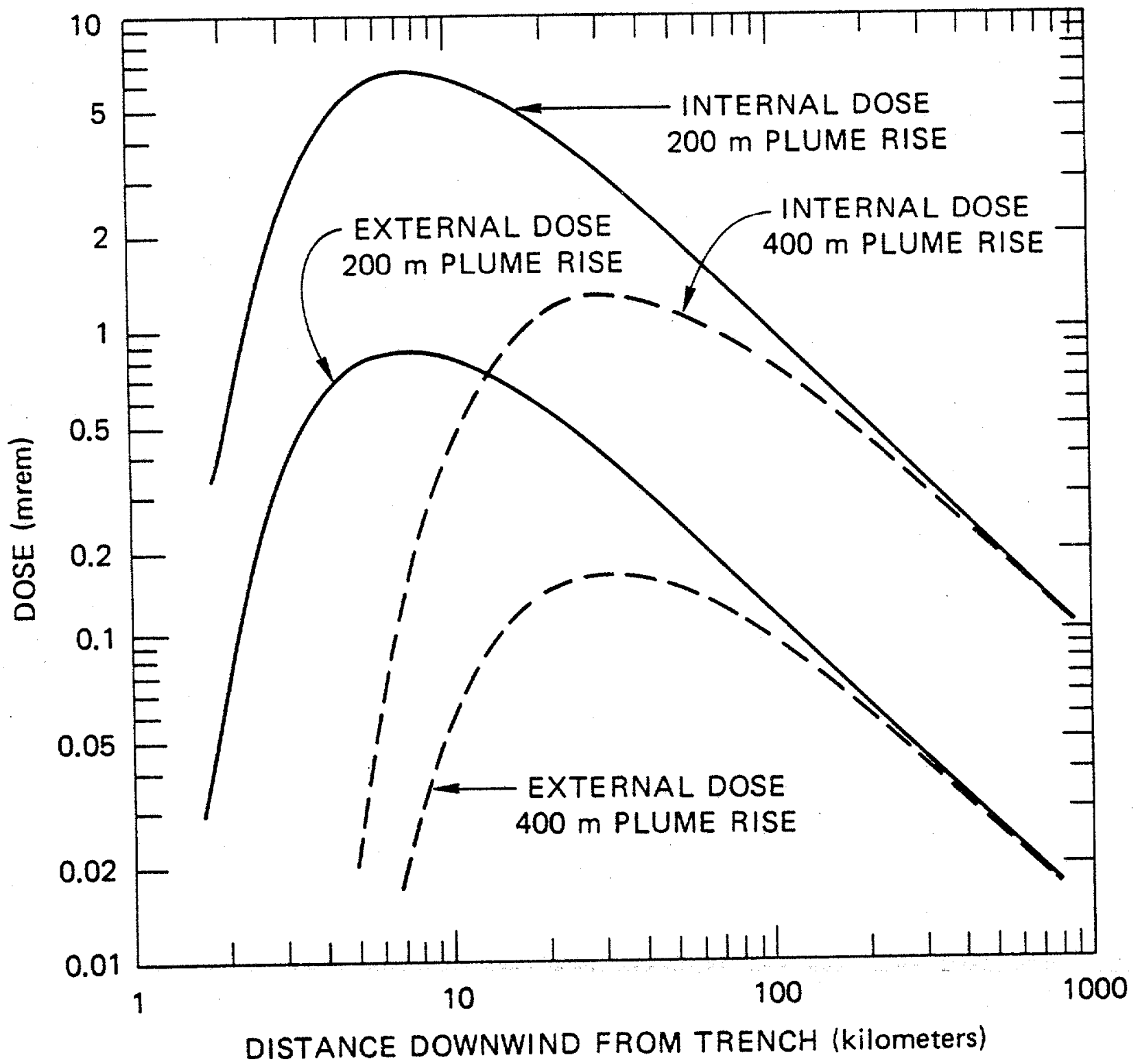

Fig. A.1. Downwind dose for a maximum plume height of $200 \mathrm{~m}$ and $400 \mathrm{~m}$ stability condition D. 


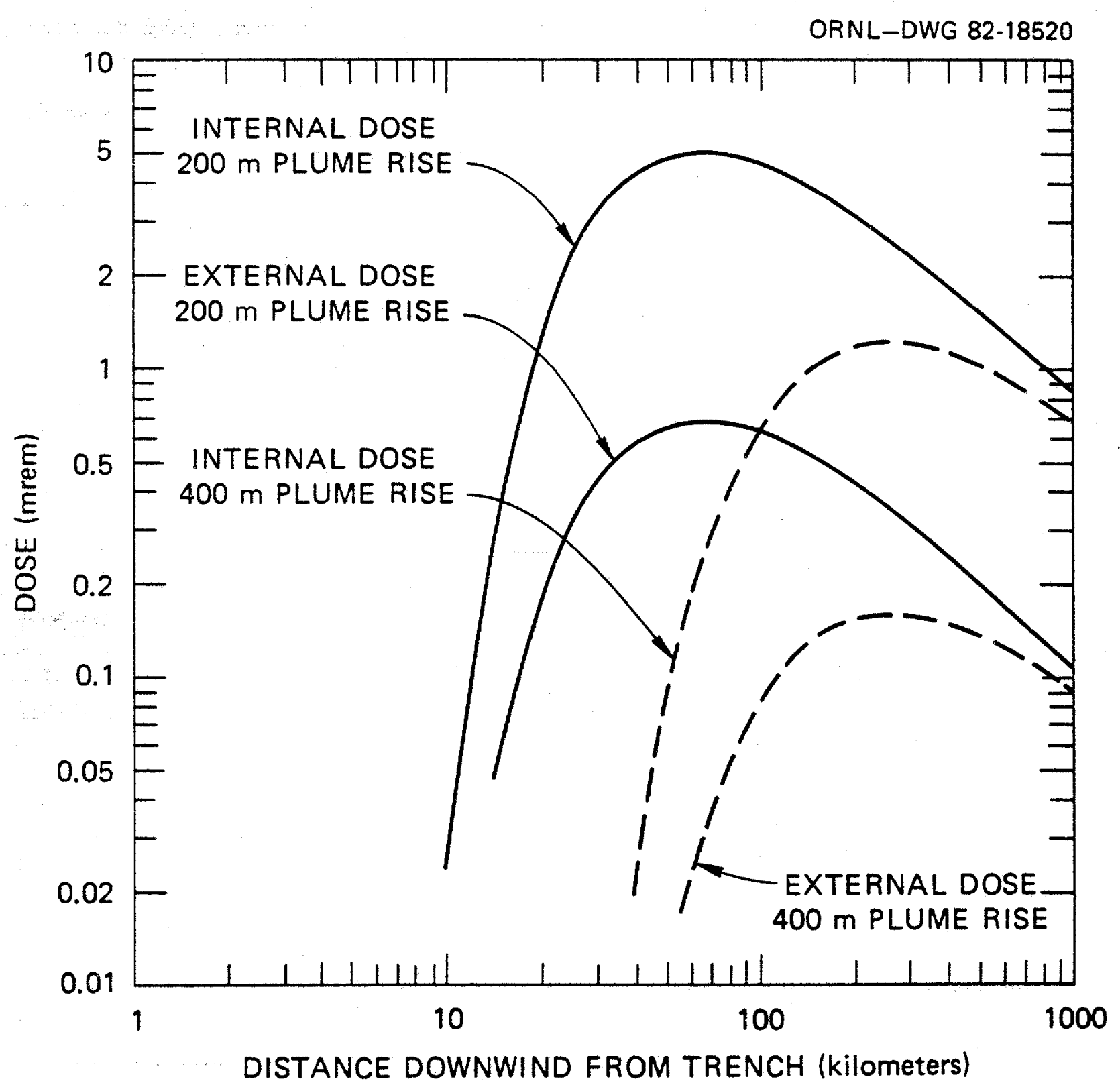

Fig. A.2. Downwind dose for a maximum plume height of $200 \mathrm{~m}$ and $400 \mathrm{~m}$ stability condition $\mathrm{G}$. 


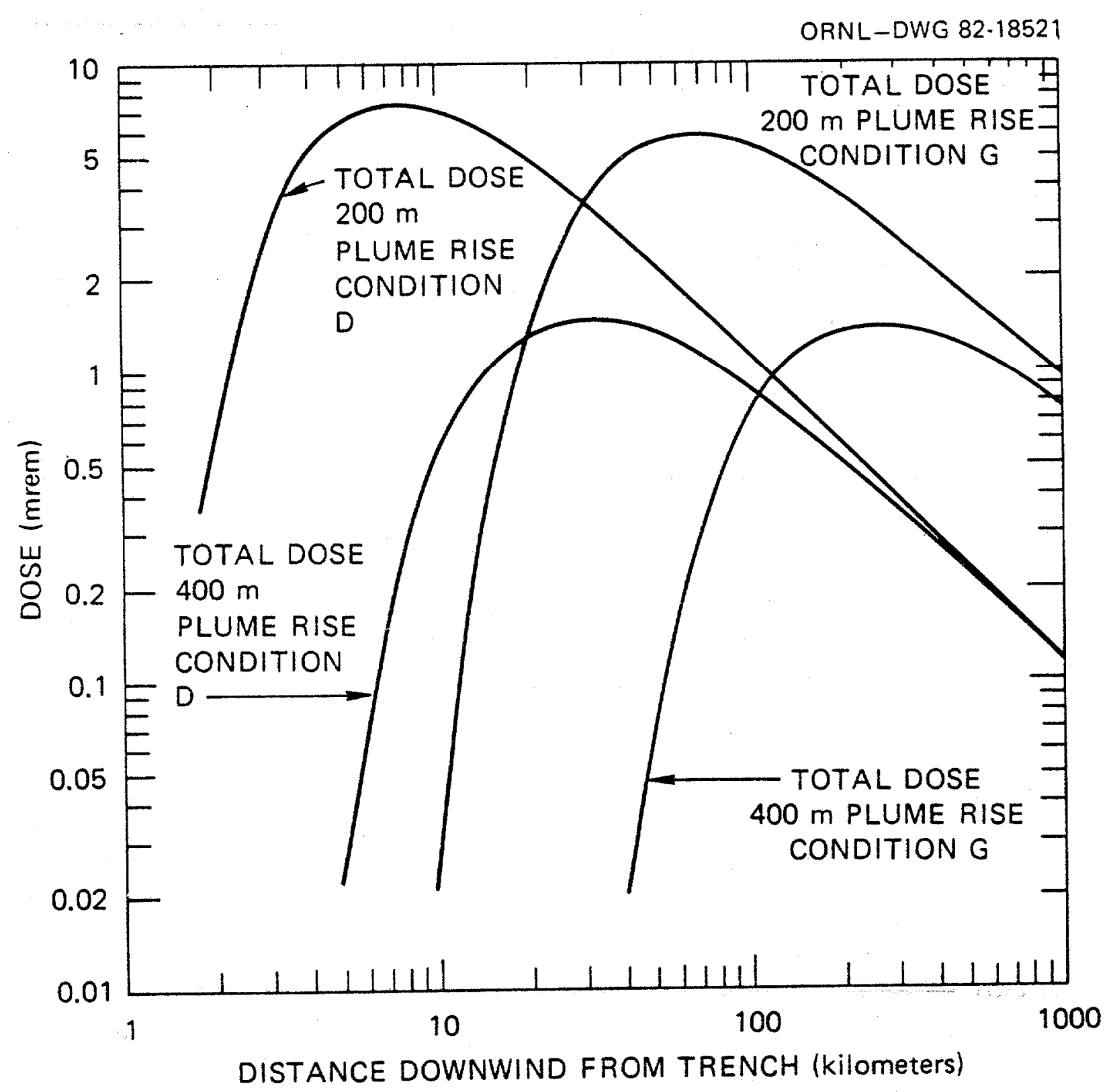

Fig. A.3. Total dose for $200 \mathrm{~m}$ and $400 \mathrm{~m}$ plume rise for 
ORNL-DWG 82.18522

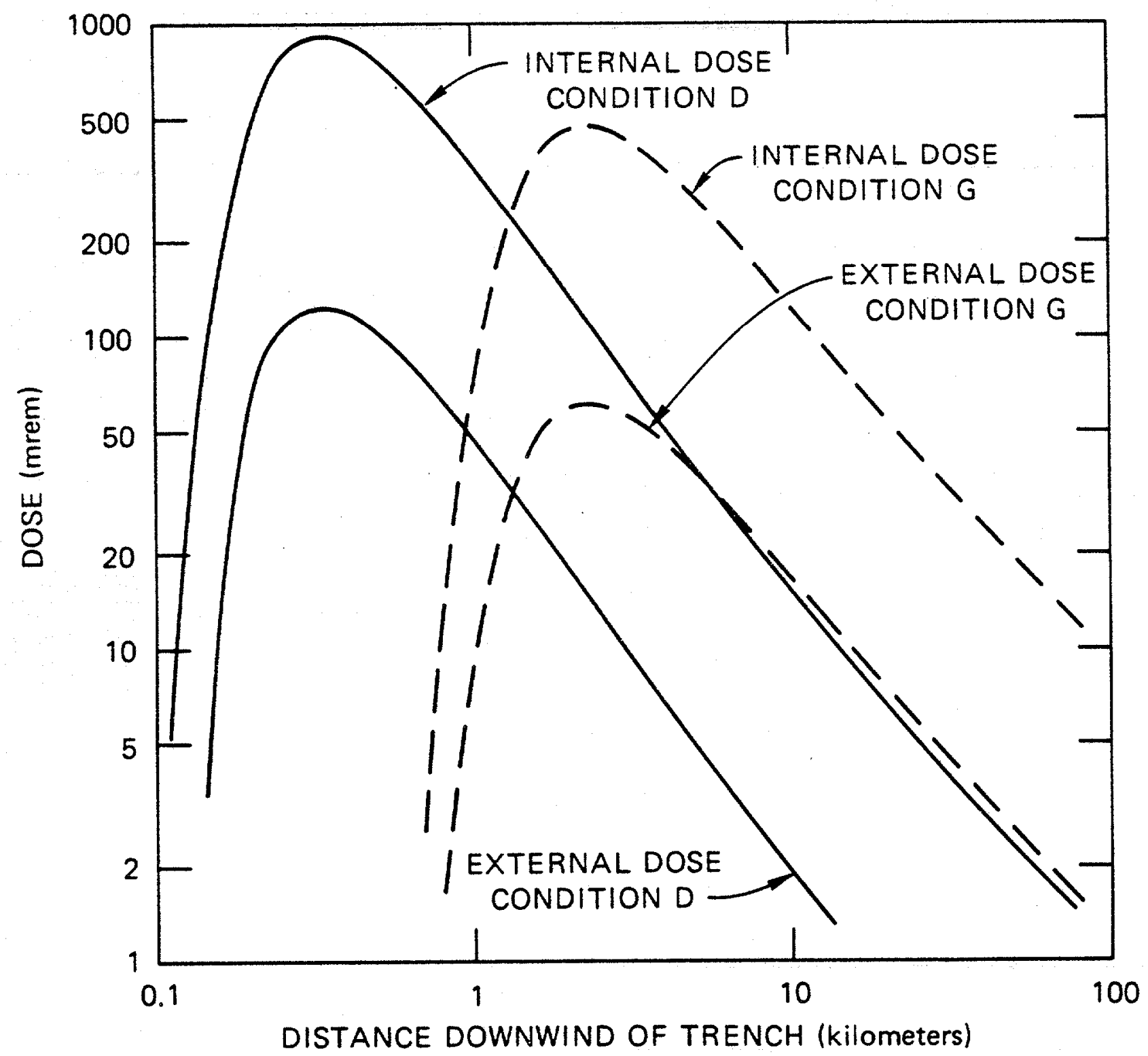

Fig. A.4. Downwind dose for an assumed plume rise of $25 \mathrm{~m}$ for stability conditions $D$ and $G$. 
Figures A.1 and A.2 show the individual internal and external dose contributions for $200 \mathrm{~m}$ and $400 \mathrm{~m}$ plume rise for both stability conditions Class D (Fig. A.1) and stability conditions Class G (Fig. A.2). Figure A.3 illustrates, for comparison purposes, the total (internal and external) downwind dose for stability conditions Class $D$ and $G$ as a function of plume rise.

Figure A.4 was prepared as an estimate of the exposure to workers in the near vicinity of the fire. This calculation assumes a plume rise of on1y $25 \mathrm{~m}$ which, although unrealistic, does provide an estimate of the upper limit exposure for unprotected personnel near the trench. The same assumptions were utilized as for the previous calculations. The results indicate that the consequences of a trench fire, even if uncontrolled, are not a major health and safety concern. The maximum total internal and external doses to unprotected personnel in the vicinity of the accident would be only slightly over 1.0 rem. The maximum total offsite dose downwind from the accident would be of less than 10 mrem. 

1. Gilbert/Commonwealth, Assessment of Alternatives for Management of
ORNL Retrievable Transuranic Waste, ORNL/Sub-79/13837/5, February 1981.

2. NUS Corporation, Low-Level Waste Pilot Facility Source Term Waste Characterization, NUS-3678 (for ORNL), November 1980 .

3. F. T. Binford, T. E. Cole, and E. N. Cranek, The High Flux Isotope Reactor Accident Analsis, ORNL-3573, April 1967.

4. F. C. Fitzpatrick, Oak Ridge National Laboratory Site Data Eor Safety Analysis Reports, ORNL/ENG/TM-19, December 1982.

5. G. A. Briggs, Plume Rise, AEC Critical Review Series, TID-25070, 1969.

6. F. Pasquil1, Atmospheric Diffusion, 2nd Edition, Halsted Press, New York, N.Y., $1 \overline{974 .}$

7. G. G. Killough and Larry R. McKay, A Methodology for Calculating Radiation Doses from Radioactivity Released to the Environment, ORNL-4992, March 1976.

8. U. S. Nuclear Regulatory Commission, Atmospheric Dispersion Models for Potential Accident Consequence Assessments at Nuclear Power Plants, Regulatory Guide 1.145, August 1979. 


\section{Distribution}

$\begin{aligned} \text { 1-4. } & \text { I. D. Bates } \\ 5 . & \text { F. T. Binford } \\ 6-7 . & \text { J. Bolinsky, Jr. } \\ 8 . & \text { E. S. Bomar } \\ 9-20 . & \text { G. H. Burger } \\ 21 . & \text { H. M. Butler } \\ 22 . & \text { C. D. Cagle } \\ 23 . & \text { G. C. Cain } \\ 24 . & \text { R. J. Clouse, Y-12 } \\ 25 . & \text { W. K. Crowley } \\ 26 . & \text { I. M. Ferris } \\ 27 . & \text { J. R. Gissel } \\ 28 . & \text { D. H. Gray } \\ 29-33 . & \text { T. Grizzard } \\ 34 . & \text { F. E. Harrington } \\ 35 . & \text { R. F. Hibbs } \\ 36-37 . & \text { P. W. Hill } \\ 38 . & \text { T. M. Hines, PGDP } \\ 39-40 . & \text { E. M. King } \\ 41 . & \text { I. J. King } \\ 42 . & \text { M. W. Knazovich } \\ 43-44 . & \text { J. R. McGuffey } \\ 45 . & \text { W. C. Kuykendall }\end{aligned}$

46. C. H. Miller

47-48. F. H. Neill

49. T. W. Oakes

50-51. G. W. Oliphant

52. D. C. Parzyck

53. C. H. Peterson, K-25

54. I. W. Pickel

55. W. E. Porter

56. T. H. Row

57. T. F. Scanlan

58. J. D. Sease

59. J. A. Setaro

60. A. J. Smith

61. K. W. Sommerfeld-H. Postma

62. I. G. Speas

63. E. O. Sternberg, K-25

64. J. H. Swanks

65. J. T. Thomas

66-67. Laboratory Records

68. Laboratory Records R.C.

69. ORNL Patent office

\section{External Distribution}

70. Assistant Manager for Energy Research and Development, DOE-ORO

71-72. Technical Information Center, Oak Ridge, Tennessee 37830 
